\title{
E DESENVOLVIMENTO ECONÔMICO
}

A reprodução da força de trabalho como elemento da dialética social

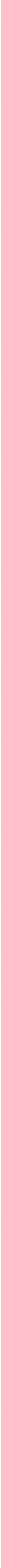




\section{JOÃO BONETT}

\section{Urbanização e desenvolvimento econômico}

A reprodução da força de trabalho como elemento da dialética social

Tese apresentada à Faculdade de Arquitetura e Urbanismo da Universidade de São Paulo para obtenção do título de Doutor em Arquitetura e Urbanismo

Área de concentração: Planejamento urbano e regional

Orientador: Prof. Dr. Csaba Deák

EXEMPLAR REVISADO E ALTERADO EM RELAÇÃO À VERSÃO ORIGINAL, SOB RESPONSABILIDADE DO $(A)$ $\operatorname{AUTOR}(A)$ E ANUENNCIA DO(A) ORIENTADOR(A).A versão original, em formato digital, ficará arquivada na Biblioteca da Faculdade.

São Paulo, 28 de agosto de 2020. 
Autorizo a reprodução e divulgação total ou parcial deste trabalho, por qualquer meio convencional ou eletrônico, para fins de estudo e pesquisa, desde que citada a fonte.

Catalogação na Publicação

Serviço Técnico de Biblioteca

Faculdade de Arquitetura e Urbanismo da Universidade de São Paulo

Bonett, João

Urbanização e desenvolvimento econômico - a reprodução da força de trabalho como elemento da dialética social / João Bonett; orientador Csaba Deák. - São Paulo, 2020.

$196 \mathrm{p}$.

Tese (Doutorado) - Faculdade de Arquitetura e Urbanismo da Universidade de São Paulo. Área de concentração: Planejamento Urbano e Regional.

1. Urbanização. 2. Desenvolvimento Econômico. 3. Brasil. 4. China. I. Deák, Csaba, orient. II. Título.| 
Nome: BONETT, João Neto.

Título: Urbanização e desenvolvimento econômico - A reprodução da força de trabalho como elemento da dialética social.

Tese apresentada à Faculdade de Arquitetura e Urbanismo da Universidade de São Paulo para obtenção do título de Doutor em Arquitetura e Urbanismo.

Aprovado em:

Banca Examinadora

1) Prof. Dr. Instituição:

Julgamento:

Assinatura:

2) Prof. Dr. Instituição:

Julgamento: Assinatura:

3) Prof. Dr. Instituição:

Julgamento: Assinatura:

4) Prof. Dr. Instituição:

Julgamento: Assinatura:

5) Prof. Dr. Instituição:

Julgamento: Assinatura: 


\section{AGRADECIMENTOS}

Agradeço aos meus pais, Eduardo e Lucimar, e ao meu irmão Matheus, que me encorajaram e se esforçaram para me manter em São Paulo nos momentos difíceis.

A Patrícia Arasake e sua família, pelo grande apoio na minha vinda a São Paulo e no início deste trabalho.

A Anna Deák, pelas conversas e comentários sobre o texto.

Aos amigos Cintia Alves, Thilo Koch, Luis Felipe Brandão e Jorge Pessoa, sempre presentes, apesar da distância.

Aos meus colegas da SPTrans e também aos meus colegas da FIAM-FAAM, com quem aprendo todos os dias.

Aos meus alunos, que me permitem o privilégio de participar da formação de futuros colegas e de aprender junto.

Ao professor Nuno Fonseca e à professora Klára Kaiser, pelas conversas e orientações.

Aos professores Alexandre de Freitas Barbosa, Karina Leitão e João Whitaker, por me receber e me direcionar em suas disciplinas.

Ao professor Alysson Mascaro, pelas valiosas sugestões.

Ao Sr. Paulo e à Dona Beth, pelas constantes preocupações.

A Luciana Itikawa, especialmente, que acompanhou, desde o início, cada passo deste trabalho, e me presenteou com meu primeiro livro sobre a China.

A Csaba Deák, que, como eu já disse uma vez, me orientou, estimulou e definiu as bases de minha consciência crítica. 
$\star \star \star$ 


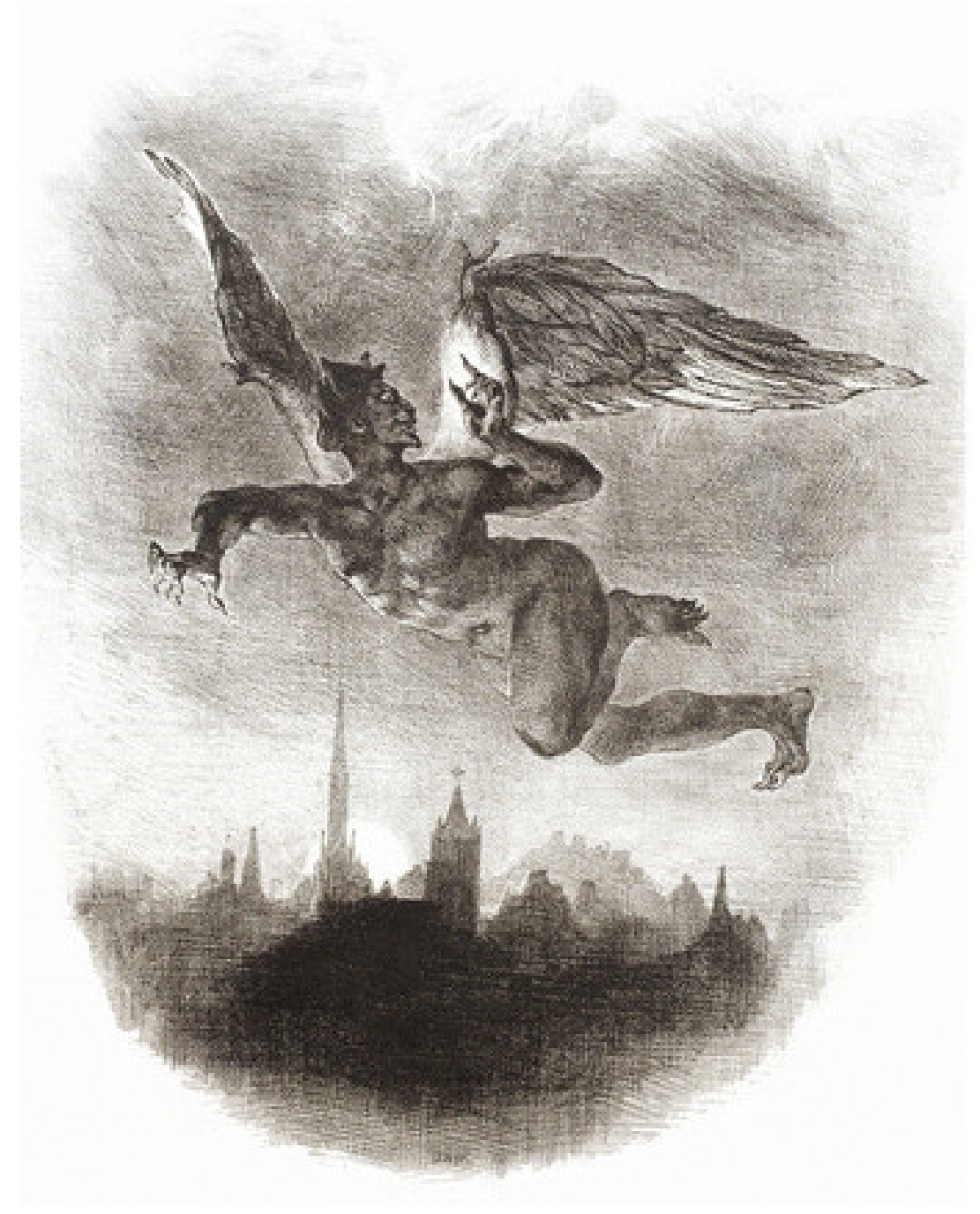


Ilustração da página anterior:

Mefisto sobrevoa uma cidade. Fausto. Eugene Delacroix, 1828.

Disponível em oldbookillustrations.com 


\section{RESUMO}

Título: Urbanização e desenvolvimento econômico - a reprodução da força de trabalho como elemento da dialética social

O argumento central desta pesquisa está inscrito na ideia de apresentar a reprodução da força de trabalho como elemento da dialética social. Constitui, precisamente, um esforço de experimentar os desdobramentos e o alcance teórico da tese de Csaba Deák sobre a dialética do mercado e do Estado, particularmente, de seus rebatimentos na produção do espaço. Para tanto, enfoca-se - pondo-o mesmo como componente essencial da análise - um aspecto da interpretação proposta por Deák: a reprodução da força de trabalho.

Argumenta-se que é a reprodução da força de trabalho, base do aumento da produtividade, o que pauta a transição entre a acumulação extensiva e intensiva. Além disso, defende-se que a reprodução da força de trabalho é elemento chave na interpretação da transformação de qualquer formação social, o que confere, de tal maneira, abrangência e unidade teóricas na investigação de distintas realidades urbanas, a exemplo da diversidade existente entre sociedades como Brasil e China, cujo cotejamento é apresentado ao longo do texto.

Palavras-chave: 1. Urbanização; 2. Desenvolvimento econômico; 3. Reprodução da força de trabalho; 4. Brasil; 5. China. 


\section{ABSTRACT}

Title: Urbanization and economic development - the reproduction of the laborpower as an element of social dialectics

The central argument of this research is the idea of presenting the reproduction of the labor-power as an element of social dialectics. It constitutes, precisely, an effort to unfold the theoretical scope of Csaba Deák's thesis on the dialectic of the market and the State, especially, its implications on space production. Therefore, it focuses on, understanding as a central feature, an aspect of the interpretation proposed by Deák: the reproduction of the labor-power.

It states that the reproduction of the labor-power is the basis of increasing productivity, which guides, by its turn, the transition between extensive and intensive accumulation. Furthermore, it argues that the reproduction of the labor-power is a key element in interpreting the transformation of any social formation, which gives, in such a way, wide theoretical framework and unity in the investigation of different urban realities, such as the existing diversity between societies like Brazil and China, whose comparison is presented throughout the text.

Key-words: 1. Urbanization; 2. Economic development; 3. Labor-power reproduction; 4. Brazil; 5. China. 


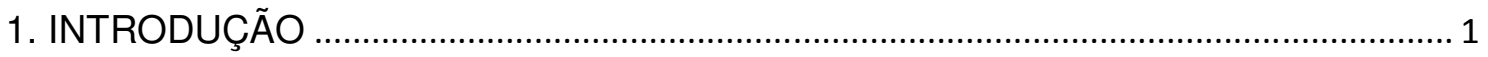

1.1. Apresentação do argumento............................................................................ 1

1.2. Método e implicações metodológicas...................................................................... 13

2. MODOS DE PRODUÇÃO E DIALÉTICA ………………………………………..... 26

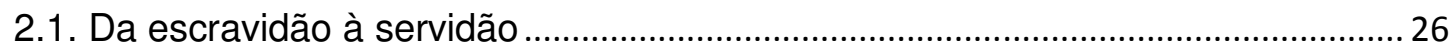

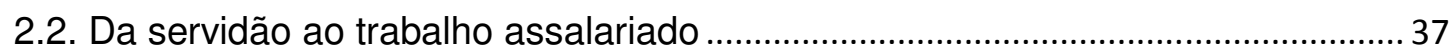

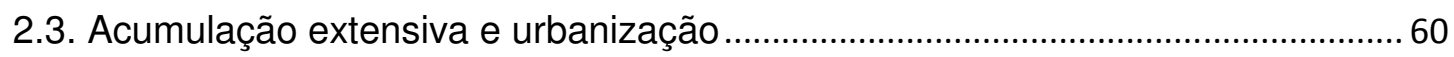

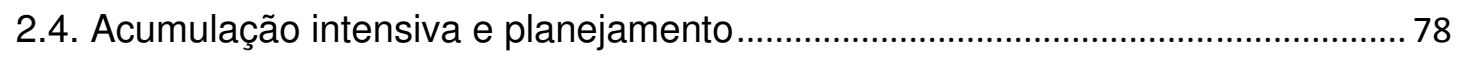

2.5. Neoliberalismo e o debate sobre o pós-fordismo ………........................................ 97

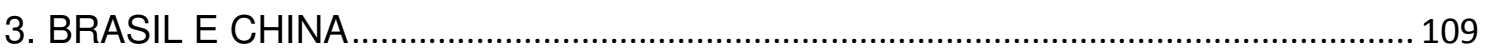

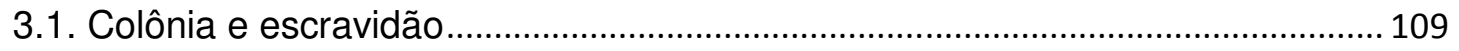

3.2. Transformações institucionais e perpetuidade material ...................................... 123

3.3. Acumulação entravada, urbanização e limites materiais .................................... 133

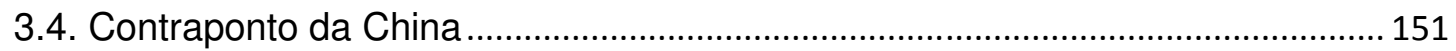

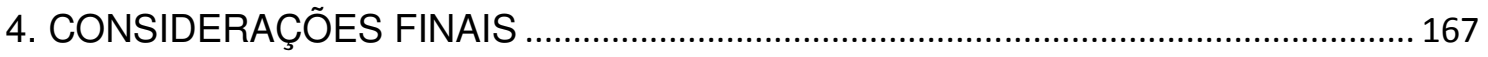

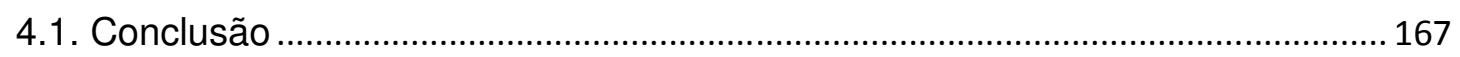

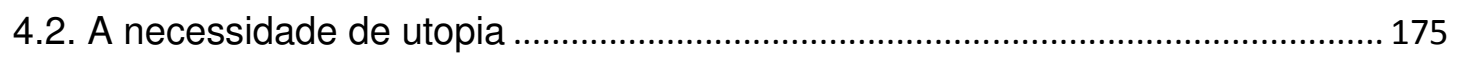

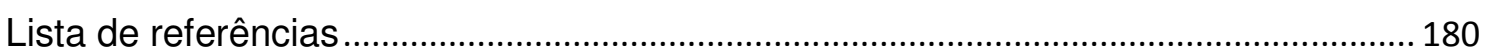




\section{INTRODUÇÃO}

\subsection{Apresentação do argumento}

Este texto se desenvolve em dois movimentos coordenados. O primeiro avança e é uma leitura da dialética do mercado e do Estado por meio de um de seus aspectos, a reprodução da força de trabalho. O segundo permanece na guarda e é a tentativa de encaminhar a crítica específica a essa leitura, qual seja, o apontamento de uma possível inversão entre o constructo que teoriza as determinações históricas - no caso, a dialética do mercado e do Estado - e os aspectos, nele, nesse constructo, determinados - particularmente, a reprodução da força de trabalho.

Em outras palavras, para a crítica, corre-se o risco de uma inversão entre o que determina e o que é determinado. Afinal é preciso compreender a sociedade como um todo para que seja possível compreender suas partes. Este trabalho está em pleno acordo com esse raciocínio e, se recorre a um elemento específico desse conjunto de determinações, é por acreditar que, ainda que de modo parcial, esse elemento - a reprodução da força de trabalho - detém uma capacidade de mediação conceitual entre as categorias mais amplas desse constructo e a materialidade tangível do tecido social.

É preciso, contudo, reconhecer a pertinência da crítica e uma de suas possíveis abordagens é discuti-la sob o entendimento metodológico do materialismo dialético. A isso está reservado o tópico seguinte, sobre método. Cumpre, preliminarmente, apresentar como a linha argumentativa se estrutura tendo como base a dialética do mercado e do Estado.

Em síntese, a dialética do mercado e do Estado é uma explicação da reprodução e da transformação da sociedade capitalista em sua longa duração - da sua gênese na baixa idade média a sua crise na atualidade. Esquematicamente, essa evolução é marcada pelos chamados estágios extensivo e intensivo de acumulação, que traduzem a generalização do âmbito da produção regulada de maneira 
descentralizada pelo mercado, fundada no lucro individual, e de sua contradição dialética com o Estado, âmbito centralizado de regulação e, por isso, antagônico, ainda que necessário, à ampliação do mercado.

$\mathrm{Na}$ origem do capitalismo, a constituição de suas relações de produção específicas resulta da generalização da forma-mercadoria sobre a esfera da produção - princípio motor do desenvolvimento histórico do capitalismo. De outro modo, é a transformação do ato de produzir, o trabalho, em mercadoria, o que consiste, como no caso europeu, na conversão de servos camponeses em assalariados urbanos, em um processo denominado, por isso, assalariamento.

A reprodução dos trabalhadores, antes viabilizada pela posse da terra em regime de subsistência e condicionada ao pagamento de renda em trabalho ou espécie - o que estabelecia, dessa maneira, a relação senhor/servo -, passou, então, a ser realizada por meio da troca de trabalho por salário. Nessa troca, as relações de produção assumem a forma de mercado, na qual os trabalhadores, com seu salário, provêm os bens, também mercadorias, necessários ao seu sustento. Completa-se, assim, o mecanismo que propaga a forma-mercadoria como princípio da regulação social, fazendo-a penetrar no âmbito da produção em uma dinâmica de extensão sobre formas pré-capitalistas - um estágio, portanto, extensivo.

De modo a justificar e generalizar essa transformação social nos padrões comportamentais e nas instituições da sociedade que assim aflorava, um conjunto de proposições jurídicas, políticas e, enfim, ideológicas tomou corpo no chamado liberalismo. Trata-se, como concebe Deák, de uma forma ideológica, que abrangia institutos como a liberdade, a igualdade e a propriedade, dando sentido e coesão à essência material da transformação da sociedade.

Como observa Marx, no plano do discurso, os trabalhadores, agora assalariados, eram livres das obrigações feudais e estavam em igualdade com a nova classe dominante, inclusive como proprietários, pois trocavam equivalentes legitimamente seus, trabalho por salário. A aparência do sistema de mercado, por isso, 
pressupõe um arranjo espontâneo entre ofertantes e demandantes de trabalho operários e capitalistas -, que, perseguindo individualmente seus objetivos, mutuamente os realizam em um processo descentralizado, como a "mão invisível" a que se refere Adam Smith, e ao qual se ajustam como elementos justificativos os preceitos liberais da liberdade, igualdade, propriedade...

Em particular, a idéia de propriedade, especialmente a propriedade da terra, repousa sobre o fundamento crucial da passagem do feudalismo ao capitalismo, do processo de assalariamento, e assinala o teor material da própria urbanização, fenômeno tão distintivo da história contemporânea. Isso porque tal transformação implicou a supressão do vínculo entre trabalhadores e a subsistência da terra, de modo que, passando sua posse a direito onerosamente adquirido, restou aos desprovidos trabalhadores o êxodo rural e a afluência às cidades, com a conseqüente venda de sua força de trabalho à indústria urbana. A urbanização é, por isso, observa Deák, o crescimento do proletariado capitalista.

Além de conformar o surgimento das cidades contemporâneas, esse estágio do desenvolvimento capitalista é caracterizado, de um lado, pelas débeis condições de reprodução da força de trabalho e, de outro, pelas altas taxas de excedente acumuladas. $\mathrm{O}$ que se sustenta nesta tese é que, no estágio extensivo, a ausência quase completa de preocupações com a reprodução da classe trabalhadora, o que é ilustrado pela precariedade do ambiente urbano desse período, está relacionada diretamente com o expressivo excedente produzido em favor das classes dominantes. Prontamente emersa das sociedades pré-capitalistas, isto é, não reproduzida pelo sistema capitalista, a força de trabalho não representa um custo interno à reprodução da nova sociedade e o excedente de sua produção é revertido quase inteiramente em prol dos extratos burgueses, como em uma redistribuição de renda às avessas.

A produção, nesse caso, ocorre em função da disponibilidade de mão de obra já assalariada, da produtividade associada a essa mão de obra e, principalmente, com 
benefício do grande contingente de trabalhadores incorporado ao sistema capitalista, em vias de serem assalariados.

Esse contingente corresponde aos movimentos migratórios entre - na realidade europeia - o campo feudal e a cidade capitalista. Assim, tem efeito de alavancar o excedente produzido pelo fato de adicionar à produção capitalista uma população de trabalhadores cujo custo de reprodução coube à outra sociedade, précapitalista. É, dessa maneira e nas palavras de Csaba Deák, um "saque" contra as formas pré-capitalistas.

Acontece que esse saque encontra limites. A população a ser assalariada esgota-se, o que mostra a virtual completa urbanização, e a expansão do excedente da produção capitalista passa a contar apenas com o crescimento da população interna de trabalhadores e com o aumento de sua produtividade. Em ambos os casos, a reprodução da força de trabalho é a base da viabilidade dessa expansão do excedente. Crianças precisam ser tuteladas, trabalhadores educados, certos padrões de qualidade de vida - o que inclui transporte, habitação, saúde... - precisam ser universalizados. Enfim, é preciso internalizar o expediente de reprodução das condições de existência do trabalho assalariado, em um processo que significa a intensificação das forças produtivas e que põe o desenvolvimento capitalista em um estágio, portanto, intensivo.

É nessa conjuntura que se fundam os chamados direitos sociais e o ideário do Bem-Estar Social, expressões jurídicas e políticas do estágio intensivo de acumulação. Para Deák, essa é a forma ideológica da Social-Democracia. É também a circunstância histórica da emergência do moderno planejamento urbano e dos melhoramentos das cidades, lócus da produção capitalista e da reprodução da força de trabalho. A primeira conclusão do exposto a ser lançada como hipótese é o fato de a ampliação do excedente no estágio intensivo da acumulação capitalista depender de uma espécie de redistribuição de renda, a melhoria das condições de reprodução da classe trabalhadora, a qual está condicionada, por sua vez, o aumento da 
produtividade. Mais importante, entretanto, é o questionamento de que maneira essa melhoria é proporcionada.

Ostado cumpre, nesse momento, papel essencial. $O$ aumento da produtividade implica o aparelhamento da força de trabalho por meio da universalização de bens e serviços que a torna mais eficiente, seja por poupar o tempo gasto em sua própria reprodução - poupando trabalho doméstico -, por diminuir o tempo gasto em deslocamentos, sobrando, assim, mais tempo para o trabalho ou descanso, por aumentar a expectativa de vida e a atividade econômica da população ou simplesmente por ampliar a capacidade produtiva de trabalhadores mais bem treinados e mais bem educados. Essa universalização - com apelo à literalidade (a todos, mesmo aos que não pagam) - significa a disponibilização desses bens e serviços a preços que não comportam lucro, o que inviabiliza sua produção por meio de um âmbito descentralizado como o mercado, cuja base do funcionamento é, justamente, o lucro individual.

Assim, uma vez que nem tudo pode ser mercadorizado, em especial bens e serviços fundamentalmente necessários ao aumento da produtividade - como transporte, habitação, saúde, educação - parte da produção passa, então, a ser produzida na forma de infraestruturas. Isto é, produzida na forma de valores de uso enquanto tais, provida por meio de um âmbito centralizado de organização da produção, o Estado, cuja manifestação de sua ação sistemática é o planejamento e sua variante espacial, o planejamento urbano. Esse movimento constitui uma dialética entre o mercado e o Estado, pois representa o crescimento deste em apoio e, contraditoriamente - dialeticamente -, em detrimento àquele, pondo em cheque sua primazia na regulação social.

No capitalismo, o Estado é uma força congênita. Para Deák, os principais campos da intervenção estatal são (1) a manutenção de instituições, como a propriedade, (2) a produção e propagação da ideologia, (3) o monopólio da violência, (4) o suporte a indústrias obsoletas que ainda são necessárias e a ramos essenciais 
da atividade econômica, como o chamado departamento I, além, é claro, (5) das infraestruturas necessárias à elevação do nível de reprodução da força de trabalho. Todas essas são ações que nascem com o capitalismo e que fazem do Estado uma esfera indispensável na sua regulação.

É o aumento da produtividade, no entanto, imperativo da acumulação capitalista em seu estágio intensivo, pós-assalariamento e marcado pela completa urbanização, o que aciona o Estado em sua dinâmica crescente e antagônica ao mercado. Por esse aumento de produtividade estar assentado na melhoria do nível de reprodução da força de trabalho, tal é o único elemento, dos cinco apresentados acima, que tem, como observou Nuno Fonseca, um movimento, uma demanda propulsora e crescente no sentido da expansão do Estado.

Os trabalhadores são os produtores diretos de toda riqueza social, portanto, sua reprodução é o que deve pautar, em última instância, a manutenção de uma sociedade. Como explanado acima, não sendo possível o avanço das condições de reprodução da força de trabalho pela regulação descentralizada do mercado, o Estado, âmbito centralizado de regulação e, por isso, antagônico ao primeiro, é, então, recursivamente acionado através dos estágios do desenvolvimento capitalista, constituindo uma dialética. Em outras palavras, com a expansão do Estado como suporte à ampliação da produção regulada pelo mercado, o primado da generalização da forma-mercadoria - em negação pelo Estado - perde a qualidade de princípio motor da organização social e impõe-se, assim, a crise da reprodução capitalista.

Nos países de capitalismo avançado, essa crise é percebida com o aumento dos gastos governamentais na contabilidade nacional. É isso, sobretudo, que a faz ser diagnosticada como um problema de ordem pública pela corrente neoclássica do pensamento político e econômico. Trata-se, como explica Deák, da forma ideológica do neoliberalismo, da qual derivam os expedientes que buscam resgatar a primazia do mercado na regulação social, como as privatizações e o cerceamento de serviços públicos. 
Tais expedientes são, contudo, inócuos. O restabelecimento do mercado como principal agente da organização da produção depende da reincorporação, em seu escopo, de atividades produtivas - e reprodutivas - que foram encapadas pelo Estado justamente pela deficiência do mercado em encaminhá-las. O que é sustentado nesta tese é que, incapazes de garantir a ampliação das condições de reprodução da força de trabalho, seja pela insuficiência de universalizar bens e serviços - de disponibilizar a preços que não comportam lucro -, seja pela necessidade de minorá-los, os postulados neoliberais atingem frontalmente o elemento que possibilita a ampliação da produção: a produtividade do trabalho.

Em suma, com a explanação acima, espera-se ter mostrado a importância da reprodução da força de trabalho como elemento para a análise da reprodução social capitalista. Neste estudo essa análise é feita no à luz da interpretação proposta por Csaba Deák sobre a dialética do Estado e do mercado, na qual tal elemento é defende esta tese - um aspecto fundamental no desenvolvimento do antagonismo entre ambos os âmbitos de regulação social (Estado e mercado).

A não reprodução da força de trabalho e sua absorção de formas précapitalistas - o que ocorre por meio do processo de assalariamento e corresponde à urbanização - explica o sucesso da acumulação extensiva e suas expressivas taxas de excedente. Seu contrário, o imperativo da reprodução da força de trabalho, determina a reorientação do desenvolvimento capitalista no sentido de seu estágio intensivo. É, assim, base de uma compreensão dialética dessa evolução.

Com essa leitura - leitura dialética através da reprodução da força de trabalho -, espera-se direcionar os questionamentos teóricos ao conteúdo cotidiano do tecido social. As grandes categorias econômicas abrem espaço para a materialidade tangível da vida, às maneiras específicas como é vivida a história no dia a dia da reprodução de trabalhadores.

Uma vez que nenhuma sociedade pode se esquivar do imperativo da reprodução de sua força de trabalho, esse aspecto, além do mais, constitui chave na 
discussão da base de existência e de transformação de distintas formações sociais, assim como, sobre as perspectivas de longo prazo que a elas se abrem, tanto individualmente quanto como parte de um organismo global. É nesse sentido que se busca, ao final da exposição, uma comparação entre Brasil e China.

A comparação entre o processo de urbanização de Brasil e China baseia-se na hipótese de que ambos os países passam pela crise de seus estágios extensivos de acumulação. Tal hipótese decorre da tese da dialética do mercado e do Estado, como acima apresentada.

Apesar das muitas diferenças históricas, culturais e políticas, Brasil e China encontram-se em um mesmo impasse de seu desenvolvimento material. Com a virtual exaustão do processo de urbanização do Brasil entre as décadas de 1990 e 2000, e a rápida urbanização da China, que em 2025 deverá apresentar taxas de urbanização superiores a $70 \%$, ambos os países esgotam suas possibilidades de acumulação extensiva.

Isto é, esgotam suas possibilidades de crescimento econômico pela incorporação de trabalhadores ao sistema produtivo, por meio do assalariamento da força de trabalho. A urbanização correlaciona-se, nesse sentido, à magnitude dessa dinâmica de assalariamento e ao passo em que sucede. Uma vez exaurido o assalariamento, o crescimento por extensão precisa, para a manutenção de uma reprodução ampliada, ser compensado pelo aumento da produtividade da força de trabalho e implica, assim, tanto no Brasil como na China, o desenvolvimento de um regime intensivo de acumulação.

No caso brasileiro, a simples necessidade de reproduzir a força de trabalho constitui um fator inédito em sua evolução material e implica uma modificação do princípio fundamental de sua reprodução social. Fundado em quase quatro séculos de escravidão, o processo econômico brasileiro nunca teve a reprodução da força de trabalho como algo elementar. Ao contrário, caracterizava os mais diversos aspectos de sua existência - as relações internacionais, a composição dos interesses das elites, 
o cotidiano - na importação contínua de mão de obra. Tratava-se de uma espécie de "defeito metabólico", como nas palavras de Luis Felipe de Alencastro, que desterritorializava a reprodução da força de trabalho em sua estrutura produtiva.

Esse defeito metabólico, ainda segundo Alencastro, estendeu-se na sociedade brasileira mesmo após a Abolição. As políticas imigratórias do final do século XIX e começo do XX perpetuaram, até a primeira metade desse último século, esse princípio de não reprodução. O que se defende aqui é que, com a acumulação extensiva, representada pela urbanização - a qual se acentua justamente a partir desse período -, a sociedade brasileira foi capaz de manter inalterada sua dinâmica social e só foi forçada a enfrentar seu esgotamento com a exaustão da acumulação extensiva na década de 1990; questão, importa dizer, ora ainda não encaminhada pela sociedade brasileira.

Para Csaba Deák, esse fato histórico - o esgotamento do estágio extensivo, do assalariamento, verificado na virtual urbanização - é o que põe em crise a acumulação entravada no Brasil. Baseada na expatriação do excedente produtivo, o entravamento econômico que caracteriza a formação social no País somente é possível mediante altas taxas de acumulação. Com o fim do regime extensivo a sociedade brasileira encara o impasse: ou transforma seu mecanismo material de reprodução, no sentido da intensificação das forças produtivas, ou deixa de acumular e perde suas feições de reprodução ampliada, diga-se, de economia capitalista.

O intuito de ler a acumulação entravada e sua crise pela ótica da reprodução da força de trabalho é enfocar um elemento cotidiano do desenvolvimento material brasileiro. É também uma tentativa de resgatar o elo de sua história de "longa duração", do Brasil colônia à crise da atualidade, pois se sustenta, aqui, que a formação social brasileira já existia independe da metrópole portuguesa desde o período colonial, sendo a não reprodução do trabalho o princípio material que pautou sua evolução histórica até os dias atuais. 
A China, por sua vez, é um caso diverso dos países ditos centrais, e, certamente, do Brasil. Lá os polos da primazia do mercado sobre o Estado estão, por assim dizer, naturalmente invertidos. O Estado é, reconhecidamente, o principal agente da regulação social, com a produção de grande volume de infraestruturas e a coordenação direta e sistemática da atividade econômica por meio do planejamento.

A exaustão do assalariamento da população trabalhadora, contudo, impõe ao desenvolvimento chinês a necessidade de uma transformação. Marcado pela progressão da urbanização esse esgotamento faz a ação do Estado, mais do que nunca, orientar-se ao aumento de produtividade do trabalho, com reflexo de maior importância sobre a reestruturação e o aparelhamento do ambiente urbano, o qual congrega as forças produtivas, em especial a força de trabalho.

Trata-se, então, de um movimento imperativo correspondente ao das ditas sociedades de mercado. O fato de a China alcançar esse momento histórico em certa simultaneidade com o Brasil torna, de tal maneira, o cotejamento entre o processo social brasileiro e o chinês algo possível e pertinente. Seus encaminhamentos, ainda que diversos, respondem a um mesmo desafio material, a passagem de um regime extensivo a um regime intensivo de acumulação.

Além disso, na atual conjuntura mundial - com a deterioração do quadro ambiental e taxas de urbanização mundiais nunca antes vivenciadas -, esses encaminhamentos não encontram paralelos na história, fazendo mesmo do caso brasileiro e chinês talvez os únicos pares de comparação possíveis. Suas escolhas pelo desenvolvimento das forças produtivas não apenas constituem formas comparáveis de tratamento, endereçadas a essa realidade específica, como também pesam consideravelmente, pelas suas próprias dimensões, na definição dos rumos do desenvolvimento mundial.

Quaisquer que sejam essas escolhas, todas acarretam a elevação das condições de reprodução da força de trabalho. A efetividade de qualquer ação em prol da intensificação das forças produtivas significa um aumento real da produtividade do 
trabalho e, para que isso aconteça, é também essencial um melhoramento na maneira como se reproduz a classe trabalhadora.

A reprodução da força de trabalho está, por isso, no centro desta interpretação sobre a evolução dos antagonismos que levam à transformação da sociedade na história, e é um importante elemento de paralelismo entre distintos processos sociais.

Montada sobre tal argumento, esta tese divide-se, a seguir, em dois capítulos. No primeiro, procura-se expor e situar o objeto estudado, tratando de ensaiar um liame entre o argumento do trabalho, teses da dialética do Estado e do Mercado e outros estudos, o que permite encaminhar questões relativas à urbanização, ao desenvolvimento econômico e aos processos nacionais e suas inter-relações no âmbito, e na evolução, de um sistema econômico mundial. Esse exercício será empreendido com a recuperação de categorias por meio da leitura histórica do desenvolvimento capitalista na Europa e, em especial, na Inglaterra, caso clássico da literatura marxista.

Com esse instrumental interpretativo, na segunda parte, o trabalho procurará enfocar o caso brasileiro, como a discussão de um desdobramento da hipótese central, no qual elemento essencial da ordem econômica brasileira é a relegada reprodução da força de trabalho, o que se reflete em sua precária e desigual configuração urbana e coloca a exaustão da urbanização no Brasil como componente chave nos encaminhamentos que a crise de seu modelo de desenvolvimento apresenta. Por fim, serão estabelecidos alguns contrastes com a urbanização chinesa, de modo a experimentar outros desdobramentos da ideia acima desenvolvida, defendendo-se interpretação de que o prenúncio da exaustão da urbanização na China impõe ao País uma agenda estatal semelhante a agenda que se impõe ao Brasil.

Dito isso, resta o ponto que esta introdução deixou aberto: a questão do método e suas implicações em face da crítica ao argumento apresentado. 


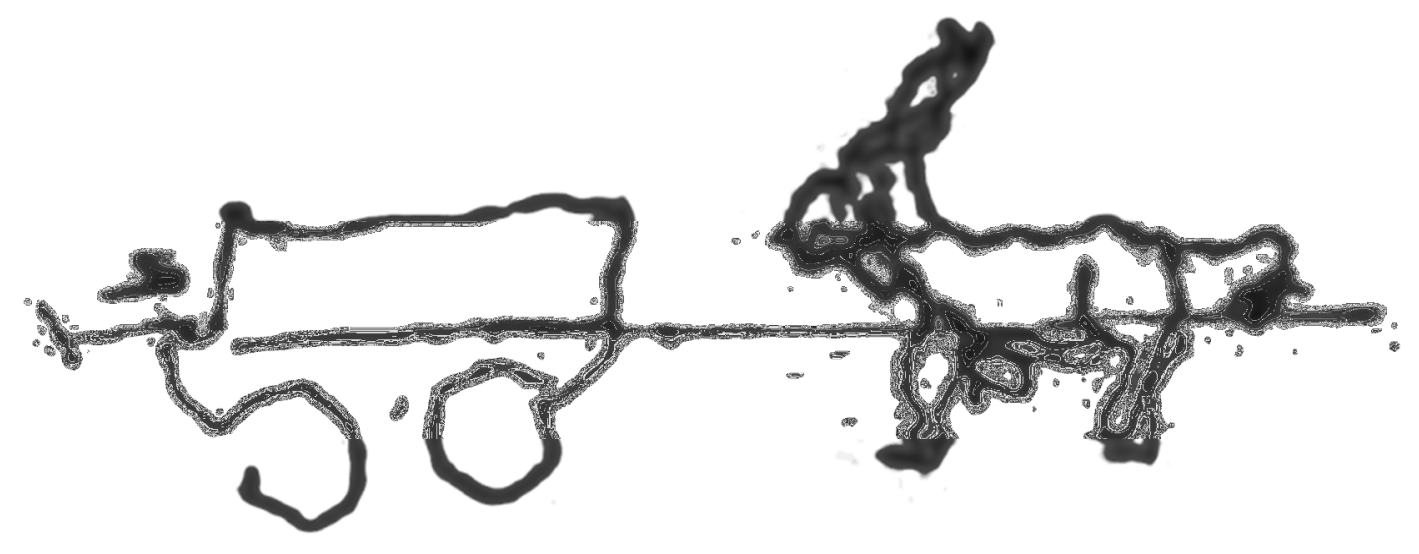

Carro à frente dos bois. Csaba Deák, 2020. 


\subsection{Método e implicações metodológicas}

As forças produtivas e relações de produção são a base da reprodução de uma sociedade. Nesse entendimento, a maneira como os indivíduos se organizam e usam os recursos à sua disposição para promover a manutenção da sociedade e para acumular o excedente necessário à sua expansão é o que conduz o desenvolvimento histórico. Seus desdobramentos são, portanto, o fundamento do método que busca capturar a essência de um processo social. Tal é, se assim é possível dizer, o roteiro de investigação do materialismo histórico e dialético ${ }^{1}$, aqui aplicado como partido metodológico deste trabalho.

No decorrer das transformações históricas, as forças produtivas e as relações de produção se desenvolvem sob condições que, ao mesmo tempo, permitem sua generalização e a intensificação das suas contradições internas, de seus antagonismos, o que constitui, assim, uma dialética. Trata-se de um movimento em qual um constructo social, ao passo que persegue seu engrandecimento e replicação, engendra também e ironicamente, os elementos que minam sua reprodução e acabam por levar à sua transformação.

Esse constructo - o concreto - é, no método de Marx, a unidade dos múltiplos aspectos que compõem uma determinada sociedade. Nele, esses aspectos são interdependentes e só existem isoladamente como abstrações - o dinheiro, as formas de trabalho, o Estado... É como se essa realidade fosse um emaranhado de fios confusamente entrelaçados e, para entendê-la, seria necessário desatar fio por fio e costurá-los novamente como antes, mas, então, com a consciência de sua estrutura. De maneira análoga, para Marx, ascendendo das abstrações é possível reconstituir, no pensamento, a totalidade dos aspectos componentes da realidade. Trata-se de

\footnotetext{
${ }^{1}$ MARX, Karl. A contribution to the critique of political economy. Prefácio. Disponível em: https://www.marxists.org/archive/marx/works/1859/critique-pol-economy/preface.htm. Acesso em: 20/12/2019.
} 
processo pelo qual se reproduz, no pensamento, a totalidade do real - o concreto no pensamento ${ }^{2}$.

Não é um "modelo", como alerta Balibar, ao qual a realidade apenas se assemelharia, como em um esboço simplificado e que deixa sempre um resíduo a ser experimentado, empiricamente comprovado. O concreto-no-pensamento é uma concepção completa da realidade e que a ela se ajusta perfeitamente, ainda que ambas, realidade completa e concepção completa, existam independentemente uma de outra ${ }^{3}$.

O concreto-no-pensamento é, por isso, o enquadramento científico que lastreia a observação e a análise dos fatos históricos e das próprias abstrações que subsidiaram sua elaboração teórica. Somente com base nessa síntese - cujo intuito é capturar e refletir no pensamento a totalidade do real - é possível alcançar uma compreensão científica dessa mesma totalidade, incluindo suas transformações e as forças motoras dessas transformações.

Em suma, os aspectos diversos da realidade social convergem a essa versão do concreto no momento de sua concepção, e partem dele no momento da interpretação da realidade. Assim, a ordem das categorias de acordo com sua capacidade de explicação não é mesma que sua sequência natural e "historicamente decisiva”. Ao contrário, sua importância na explicação de uma realidade social está arranjada conforme seu papel na reprodução dessa sociedade ${ }^{4}$.

Como exemplifica Marx: a terra, na sociedade feudal, é uma categoria essencial, mas secundária na sociedade capitalista, em que as transformações do capital marcam o princípio governante. Isto é, na sociedade capitalista, a terra - que tantas vezes reaparece em uma pretensa forma teórica própria, a renda da terra - não pode ser entendida sem uma compreensão do capital, mas o capital pode muito bem

\footnotetext{
2 Ibidem.

${ }^{3}$ ALTHUSSER, Louis. BALIBAR, Etienne. Reading Capital. Londres: Verso, 1979. p. 257.

${ }^{4}$ MARX, Karl. MARX, Karl. A contribution to the critique of political economy. Prefácio. Op. Cit.
} 
ser compreendido sem a terra ${ }^{5}$. Dessa maneira, tomar um aspecto do concreto, sem o posicionar na concretude teórica concebida como representação desse último no pensamento, é, como se diz, colocar o carro à frente dos bois.

Tal concepção da concretude é entendida, aqui, como a representação de toda a substância histórica que engloba a existência de uma sociedade, os imperativos de sua reprodução e os antagonismos que encaminham sua transformação. Na literatura marxista - heterogênea e muitas vezes divergente (inclusive nos trabalhos de Marx) -, talvez seja possível dizer, e está é a posição deste trabalho, que essa idéia do concreto encontra expressão nos conceitos de modo de produção e formação social.

Marx e Engels concebiam quatro modos de produção historicamente vivenciados. São eles os modos de produção primitivo, antigo, feudal e capitalista ${ }^{6}$. Trata-se, respectivamente, das relações tribais de produção, da escravidão da antiguidade, da servidão feudal e do trabalho assalariado capitalista. (reserva-se um trecho adiante sobre as controvérsias e explorações a respeito de outros modos de produção, como o "modo de produção asiático"). Cada um desses modos de produção é definido por relações de produção próprias, vivido por meio de formas ideológicas próprias e transformado por uma dialética também própria, contemplando, por isso, certa totalidade.

Mas é Althusser quem explicitamente articula a idéia de totalidade social a um conceito específico: o de formação social. Em sua definição, uma formação social constitui uma estrutura dominante da totalidade social, emersa de um modo de produção e compreendendo um complexo inseparável dos diferentes níveis de sua existência, isto é, a base econômica e as superestruturas políticas e ideológicas. Avançando sobre essa definição, tem-se, portanto, os tipos de sociedade - os modos de produção - e as sociedades específicas - as formações sociais -, as quais, para Althusser, não podem existir em sentido "geral". Sua existência é sempre peculiar, de

\footnotetext{
${ }^{5}$ Ibidem.

${ }^{6}$ MARX, Karl. ENGELS, Friedrich. A ideologia alemã. São Paulo: Hucitec, 1989. p. 6-9;28.
} 
modo que sua história é, na crítica de Althusser sobre o Tempo Histórico e a ausência da teoria da história, uma estrutura específica de historicidade, que não tem significado senão em função da essência dessa peculiaridade ${ }^{7}$.

Se aqui entendido corretamente, essa compreensão sobre a particularidade das formações sociais, como totalidades específicas afloradas de um modo de produção, é o que gera neste trabalho sua grande questão e dificuldade metodológica. A miríade de formas reais que as relações de produção assumem tornam, na visão deste trabalho, o estudo das formações sociais e o esforço para se chegar a um concreto-no-pensamento algo não tão simplesmente apreendido, algo não trivial, a ponto mesmo de se questionar, aqui, sua possibilidade.

Afinal, o que é uma relação de produção? (Uma forma de trabalho? Uma a relação entre classes? Uma condição de propriedade ou posse?). Se todas essas perguntas se referem a aspectos de um mesmo objeto concreto, confluindo a uma realidade multifacetada na qual não é possível separá-los, então, em que elemento pode residir a essência para diferenciar uma de outra relação de produção? Diferenciar uma de outra formação social? E, principalmente, de que elemento pode erigir os antagonismos de sua transformação?

Como exemplo da dificuldade que se quer apontar, tome-se a observação de Fernand Braudel sobre a existência do campesinato feudal. Para Braudel, "há mil maneiras de ser camponês". Podem os camponeses ser escravos, servos, foreiros livres, meeiros e rendeiros. Podem depender da igreja, da realeza, de toda a sorte de nobres e fidalgos e mesmo de outros camponeses e de outros rendeiros. Sua existência varia tanto na história como no espaço, pois havia na Europa uma pluralidade de estatutos, assim como houve em qualquer parte do mundo - a exemplo do Japão feudal ${ }^{8}$.

\footnotetext{
${ }^{7}$ ALTHUSSER, Louis. BALIBAR, Etienne. Reading Capital. Londres: Verso, 1979. p. 91-105.

${ }^{8}$ BRAUDEL, Fernand. Civilização material, economia e capitalismo: séculos XV-XVIII. V. II, o jogo das trocas. São Paulo: Martins Fontes, 2009. p. 222.
} 
Nem mesmo a idéia de predominância numérica parece ajudar nessa caracterização. Na Inglaterra da época do Domesday (espécie de censo ordenado por Guilherme I), os trabalhadores do campo dividiam-se em 4 grandes classes: os escravos (9\%), os cotters (32\%), os vilãos (38\%) e os homens-livres (12\%). Ainda, além de burgueses, jornaleiros, artesãos e das classes tradicionais (nobreza e clero), havia também uma série de termos, na maioria das vezes não equivalentes, que denominavam classes sociais relacionadas ao campo, como yeoman, husbandman, sokemen... E isso só na Inglaterra". Na Alemanha houve os ackermanns ("Homem do campo", ou literalmente "homem de acre"), os waldbauers ("cultivador das florestas")...

É muito plausível que essa multiplicidade estenda-se a qualquer modo de produção. Geoffrey de Ste. Croix, por exemplo, observa a existência de diferentes formas de trabalho "não livre" na antiguidade. Formalmente, havia uma série de termos gregos e latinos que designavam esses tipos e que impõem hoje desafios à conceituação de trabalho escravo nas sociedades antigas. Palavras gregas como pais (menino), soma (corpo), doulos, andrapodon, oiketes, ou muitas outras latinas, como servus e mancipium, parecem ilustrar a existência de gradações entre a completa escravidão e o trabalho livre, assim como, entre diferentes sociedades. $O$ autor assinala com importância, no entanto, que, nos estatutos antigos, a única distinção efetiva era apenas aquela entre pessoas livres e não livres ${ }^{10}$.

No capitalismo, a diversidade é especialmente notória. A informalidade, as formas deturpadas de trabalho assalariado, o trabalho doméstico, os autônomos, os "por conta própria", a "uberização"... entre tantas outras formas de existência do trabalho, convivem, às vezes sem qualquer predominância, com as relações salariais típicas, tidas como o padrão das relações de produção capitalistas. Essas formas certamente estabelecem múltiplas relações entre classes, representam maneiras

\footnotetext{
${ }^{9}$ MORTON, Arthur Leslie. A história do povo inglês. Rio de Janeiro: Civilização Brasileira, 1970. p. 52.

${ }^{10}$ DE STE. CROIX, Geoffrey Ernst Maurice. The class struggle in the Ancient Greek World. Nova York: Cornell University Press, 1981. p. 130-135.
} 
várias de exercício do trabalho e comportam diferentes modos de posse e propriedade do capital.

De tal maneira, em decorrência do exposto, é difícil conceber uma síntese teórica da totalidade social que lide com tantas particularidades. Lança-se, por isso, a dúvida sobre a possibilidade de se discutir distintas formações sociais, como totalidades, sem a multiplicação de análises ad hoc, cujo aprofundamento leva a apenas a conclusão de que se trata de instâncias isoladas e absolutamente incomparáveis. No extremo, cai-se no absurdo de imaginar um todo composto de paralelismos de efeitos impossíveis de serem concebidos em conjunto, efeitos sobre o todo, sobre o mundo, e que dele nada dizem.

Barry Hindess e Paul Hirst chagam mesmo a negar a possibilidade dessa síntese teórica, negam a possibilidade de "apropriar no pensamento o concreto". Para tais autores, depois de uma extensa e reconhecida pesquisa sobre modos de produção pré-capitalistas, a própria idéia de modo de produção precisava ser repensada por um novo método de conceituação que enfocasse as relações de produção e suas condições de existência ${ }^{11}$. Em outras palavras, que tratasse de sua reprodução, conceito de destaque nos trabalhos de Althusser e de Balibar.

Embora os modos de produção, visto em seu desenvolvimento histórico, pressuponham uma transição, uma teoria da transição, Marx e Engels nunca se debruçaram especificamente sobre essa construção ${ }^{12}$. Esse ponto, entretanto, permaneceu central no debate marxista, como ilustra a preocupação de tantos autores sobre o tema, a exemplo do paradigmático debate protagonizado por Paul Sweezy e Maurice Dobb ${ }^{13}$.

Para Balibar, a categoria base dos modos de produção era mesmo insuficiente para tal, constituindo, sua leitura, um quadro estático da história. Em sua crítica, o

\footnotetext{
${ }^{11}$ HINDESS, Barry. HIRST, Paul. Mode of production and social formation. Londres: Macmillan Press, 1977. p. 6.

${ }^{12}$ BOTTOMORE, Thomas. Dicionário do pensamento marxista. Rio de Janeiro: Zahar, 2001. p. 387.

${ }^{13}$ SWEEZY, Paul. et all. A transição do feudalismo para o capitalismo. Rio de Janeiro: Paz e Terra, 1978.
} 
modo de produção é uma abstração capaz de explicar a singularidade das formas e a maneira específica como seus diversos elementos se combinam em um todo, mas "deixa entre parêntesis a questão da sucessão"14.

Vale dizer, se o conceito de modo de produção é capaz de delinear, por um lado, os contornos de cada modo de produção, por outro, é insuficiente para cotejar a interface entre eles, precisamente sua transformação e transição. Capta sua existência discreta, em quadros, mas não contínua na história, a qual implica, visto a natureza distintiva de cada modo de produção, sua variação, sua metamorfose.

E, nesse sentido, é possível não apenas pensar essa continuidade como variedade que se desenvolve no tempo, em sua ordem de existência, mas também no espaço, em sua ordem de co-existência. Isto é, variedade entre diferentes formações sociais que não podem colapsar sobre um mesmo conceito, que não podem ser reduzidas a um esquema geral - do mesmo modo que o rótulo "capitalismo", por exemplo, não é suficiente para caracterizar e indicar as diferenças entre Brasil e outra sociedade capitalista.

Assim, um "segundo conceito", de mesmo nível teórico que o conceito de modo de produção - como assinala Balibar -, apresenta-se como necessário nesse questionamento: o conceito de reprodução. Tal conceito centrar-se, para Balibar, na própria continuidade, porque nele estão contidos os três tipos de elos que a garantem. Trata-se do elo entre os agentes econômicos, que se sucedem continuamente; do elo entre os diferentes aspectos da totalidade social (aspectos econômicos, ideológicos e políticos), uma vez que a reprodução social é sempre completa, total; e, finalmente, do elo da produção, que não pode parar e, por isso, sua necessária continuidade está inscrita na identidade que emerge de um processo produtivo e adentra outro, como os meios de produção que antes foram produtos, e trabalhadores e não trabalhadores que se reorganizam, como classes, na divisão do produto social ${ }^{15}$.

\footnotetext{
${ }^{14}$ ALTHUSSER, Louis. BALIBAR, Etienne. Reading Capital. Londres: Verso, 1979. p. 254.

${ }^{15}$ Ibidem.
} 
Uma análise da reprodução social, portanto, coloca em movimento o que Balibar aponta como estático e articula aspectos que concebe como isolados. É o cerne da permanência das condições de produção e, dessa maneira, considerando o todo social, deve ser também a essência de sua mudança e reestruturação ${ }^{16}$. À vista disso, essa abordagem encaminha, aqui, um tratamento conceitual para a continuidade, para a transição, e, por extensão, para a variedade do constructo social que este trabalho procura discutir. Em breve retorna-se a ela, mas antes é preciso observar que a problemática do concreto-no-pensamento, acima apresentada, não parece estar resolvida.

Nessa abordagem, compreender a reprodução de uma formação social ainda exige que o ponto de partida dessa análise seja, nada a menos, do que a totalidade de sua realidade. Se a possibilidade de englobar no pensamento essa totalidade é posta em dúvida, então, qualquer análise será sempre parcial - no sentido de não total - e corre o risco de colocar sempre o carro à frente dos bois, de valorizar os fios ao invés do tecido, de fazer o rabo balançar o cachorro... Isto é, o aspecto, a abstração, é o que deve ser explicado pelo concreto, e não o contrário. Mas se o concreto - nesse enquadramento metodológico - for impossível no pensamento, o que resta?

Tal dificuldade conceitual, de fato, se impõe ao desenvolvimento deste trabalho e, na incapacidade de solucioná-la, procura-se assumi-la. A idéia é que, sem negar o concreto real e de que dele decorrem as abstrações do pensamento - ou seja, os aspectos aqui enfocados - é possível, com a leitura dessas abstrações e ainda que de uma maneira parcial, extrair conclusões importantes sobre a realidade e sobre seu encaminhamento.

Se fosse aplicável uma analogia à geometria, este exercício se assemelharia ao estudo de uma forma de dimensões inconcebíveis. Um hipercubo, por exemplo, é o correspondente de um cubo em quatro dimensões. Mesmo que ninguém possa imaginar tal figura, conclusões sobre ela são possíveis. Reduzindo-a a três dimensões

\footnotetext{
${ }^{16}$ Ibidem.
} 
- do mesmo modo que se reduz um cubo a um quadrado em uma projeção ortogonal -, é possível comparar suas proporções, dizer se seu tamanho é adequado a um determinado espaço e até estimar quanto material seria necessário para construí-la.

Com concessões ao exemplo, isso é o que este trabalho faz. Busca nos aspectos tangíveis da realidade, portanto não na totalidade de suas dimensões e embora sem a negar, elementos que permitam conclusões sobre ela, especificamente sobre sua reprodução e conseqüente transformação. Voltando, pois, a questão da reprodução, argumenta-se que, apesar de se desconhecer uma maneira de tratá-la em sua totalidade, é possível dar algum norte a sua discussão se aquela for tomada em seus elementos parciais, os quais estão centrados, aqui, na reprodução da força de trabalho.

Para Althusser, a reprodução de uma formação social depende da reprodução (1) das forças produtivas e (2) das relações de produção. As relações de produção têm sua reprodução assegurada pela superestrutura política e ideológica, a qual já é presente, vale lembrar, na infraestrutura material da produção. Ou seja, está na amálgama do concreto social, apesar da linguagem "topográfica" (superestrutura e infraestrutura), como observa o autor. As forças produtivas, por sua vez, dependem da manutenção de duas estruturas específicas: (1A) os meios de produção e (1B) a força de trabalho ${ }^{17}$.

A reprodução da força de trabalho, particularmente, implica não apenas a subsistência dos indivíduos e de suas gerações, mas também a reprodução de suas habilidades e da sua submissão ao sistema dominante. Logo, é uma variável que se define em um tempo histórico específico, pois as necessidades dos trabalhadores são socialmente estabelecidas e, sobretudo, por meio de um constructo que envolve a materialidade da economia e das formas políticas e ideológicas ${ }^{18}$.

\footnotetext{
${ }^{17}$ ALTHUSSER, Louis. On the reproduction of capitalism: Ideology and Ideological State Apparatuses. Londres: Verso, 2014. p. 47-52.

${ }^{18}$ Ibidem.
} 
Althusser, dessa maneira, não retrocede na compreensão da totalidade social, mas sua exposição abre espaço para uma abordagem mais analítica. Nela, a reprodução da força de trabalho é uma das dimensões da reprodução social e enfocála, nesta interpretação, se deve ao fato de essa dimensão constituir relação direta com os antagonismos do processo social como um todo.

Os trabalhadores são os agentes imediatos da produção e, por isso, são um elo primário na reprodução social. Uma definição sobre força de trabalho - sobre classe trabalhadora -, além desse enunciado geral, somente é possível de ser esboçada no âmbito próprio de um modo de produção ou mesmo de uma formação social particular.

Além disso, é evidente que a relação com a produção se estabelece de maneira gradual e, sobretudo, contínua. Todos são agentes da produção. Entretanto, quanto mais próximo do pináculo social um determinado extrato da população se encontra, mais esse se afasta da materialidade, do corpo, do processo produtivo e mais intensamente a esse converge o esforço coletivo da reprodução, inclusive em sua mais elementar acepção: o cuidar, o alimentar, o desenvolver.

Nesse sentido, essa grande base da pirâmide social, a força de trabalho - seja qual for o tempo histórico ou a formação a que pertence - faz duplamente jus a mais essa metáfora edilícia. Os trabalhadores são o sustentáculo da produção e também da reprodução de todos aqueles que produzem. Conceituar a força de trabalho como classe ou estudar suas infindáveis e complexas relações no concreto social restitui a mesma dificuldade que põe às voltas este ensaio. Mas se essas pretensões forem deixadas de lado e o empenho for orientado por essa ótica da reprodução, a força de trabalho passa a ser sensivelmente útil na análise da cadeia de fatos que realizam e transformam uma sociedade: sendo base, os efeitos sobre ela propagam-se por toda a estrutura.

A maneira específica como a força de trabalho é reproduzida está intrinsecamente vinculada às relações de produção. É algo, além disso, cotidiano e 
palpável - que, como se diz, sente-se na pele - e, assim, presta-se a uma viva caracterização dessas relações de produção. Acima de tudo, qualquer perturbação na viabilidade de sua existência põe em movimento todo o constructo social, que se rearranja de modo a garanti-la, constituindo, assim, elementos que lançam luz sobre a dialética do processo social.

Neste texto, sustenta-se que, nas sociedades capitalistas, os antagonismos de suas transformações podem ser lidos dessa maneira. Conforme Althusser, a força de trabalho é, no capitalismo, em parte reproduzida por meio do salário, que se define no âmbito da relação capital/trabalho, no âmbito da "firma". Sua tese, contudo, projeta para além dessa relação a completa reprodução dos trabalhadores, a qual é, incrementalmente, realizada por outras instâncias ${ }^{19}$.

Não poderia isso ser pensado como uma dialética entre a relação capital/trabalho e essas outras instâncias de que fala Althusser (que, cá, não se imagina outra senão o Estado)? Apesar da compreensão, esse tópico é pouco desenvolvido no trabalho de Althusser e restrito à questão dos aparelhos ideológicos. Mas Csaba Deák, avançando sobre muitas dessas considerações, apresenta interpretação a qual o presente argumento encontra correspondência, sendo baseado nela, na verdade.

Trata-se da dialética entre Estado e mercado, em que a melhoria das condições de reprodução da força de trabalho é uma função indelegável do Estado. Sendo assim, defende-se aqui, a reprodução da força de trabalho é um componente dessa dialética. Mais do que isso, sobre esse elemento enfeixam-se os conceitos de estágios de acumulação extensiva e intensiva, assalariamento, urbanização e seu tratamento, ao qual também se alinham a essência e os objetivos do planejamento urbano.

Especificamente, a acumulação extensiva representa a extensão das relações capitalistas de trabalho, isto é, o crescimento do proletariado, que, migrando do campo

\footnotetext{
${ }^{19}$ Ibidem
} 
à cidade, faz desse processo o próprio processo de urbanização. No âmago, essa dinâmica baseia-se na não - ou ocorre sem grandes preocupações com a reprodução da força de trabalho.

Com seu esgotamento, a acumulação capitalista necessita aparelhar a força de trabalho e elevar o nível de sua reprodução para sustentar o crescimento econômico que, então, passa contar apenas com o aumento de produtividade para a expansão do excedente. Essa necessidade marca a condição histórica para o surgimento da moderna e sistemática intervenção estatal por meio do planejamento e da produção de infraestruturas, constituindo, por extensão, o conteúdo do planejamento urbano.

Dessa maneira, percorrer essas categorias e essa dialética sob o entendimento da reprodução da força de trabalho costura sua discussão a um aspecto tangível dessa complexidade real, permitindo, dela, extrair conclusões. O passo seguinte, então, é ilustrar como tal intenção pode ser amadurecida.

Para tanto, tendo a dialética do mercado e do Estado como ponto de chegada, o que se propõe no próximo capítulo é desenvolver essa compreensão com base em uma exploração da evolução histórica, em especial, da sociedade europeia simplesmente pelo fato de essa constituir um exemplo clássico da literatura marxista. A ideia é mostrar como, passando da antiguidade ao feudalismo, e desse ao capitalismo, a reprodução da força de trabalho pode ser lida na qualidade de uma privilegiada perspectiva sobre processo social e sobre sua transformação no tempo. 


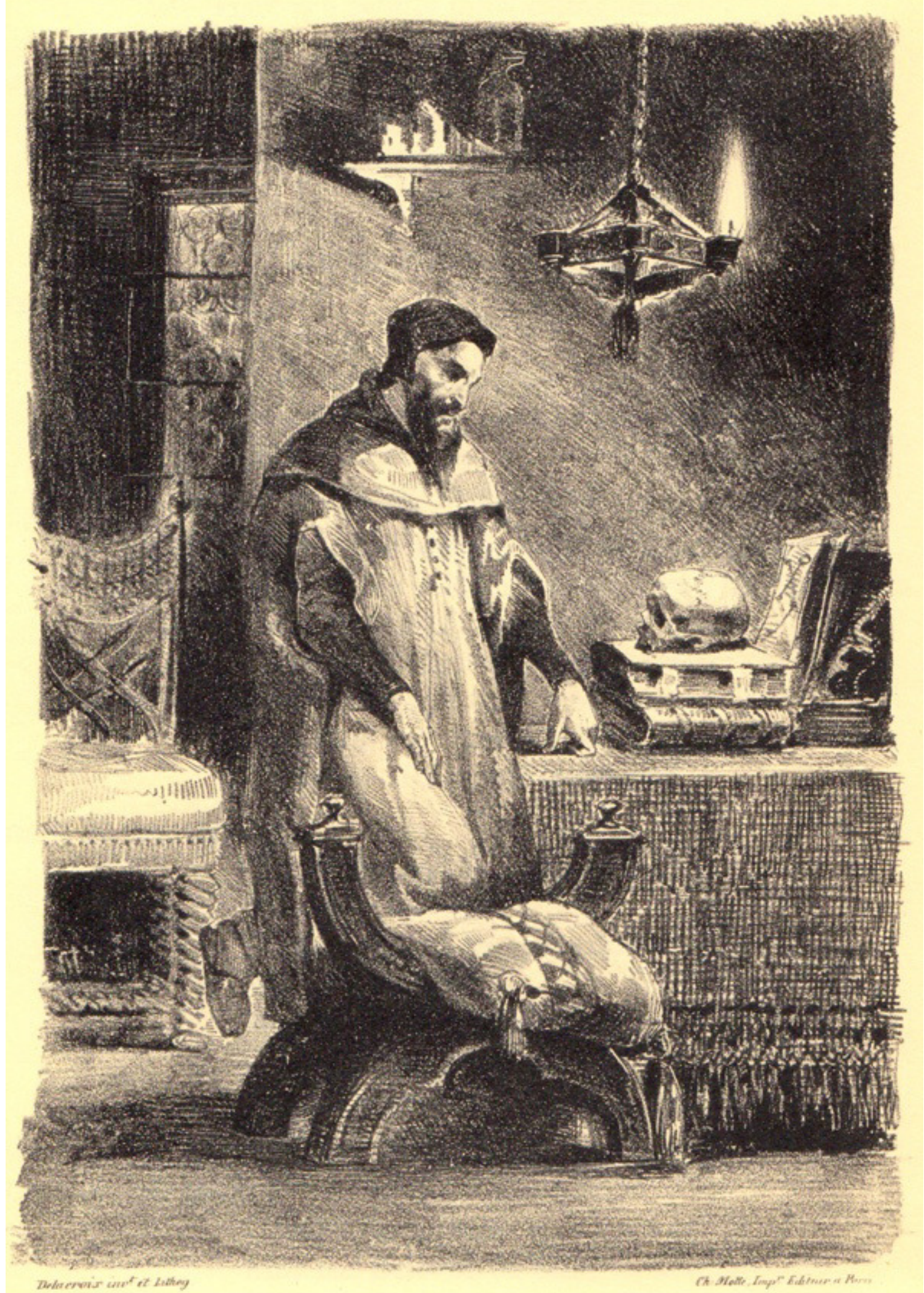

FaUsT: Why grin, you hollow skull?

Fausto. Eugene Delacroix, 1828.

Disponível em oldbookillustrations.com 


\section{MODOS DE PRODUÇÃO E DIALÉTICA}

\subsection{Da escravidão à servidão}

Como caso primeiro da exploração desta exposição, o texto a seguir é uma breve conjectura sobre escravidão na antiguidade e suas decorrências, que adentraram a idade média e deram origem ao feudalismo. Na linha da interpretação aqui proposta - isto é, compreendendo a reprodução da força de trabalho como elemento do processo social -, a essência da escravidão é justamente negativa, reside na não reprodução dos trabalhadores.

As sociedades antigas tinham sua existência baseada na incorporação de trabalhadores que não eram por elas reproduzidos. Esses impérios dependiam de exércitos que promoviam guerras de conquista contra outros povos, cuja função, além da pilhagem de recursos, era, sobretudo, o suprimento de mão de obra, em regime de trabalho compulsório, necessário à manutenção social e à estrutura de classes da antiguidade.

O escravo, nesse sentido, era quase sempre um estrangeiro. É essa a ideia que Aristóteles reiteradamente sustenta em "A Política", a de que todo trabalho manual necessário ao sustento de um Estado deve ser, idealmente, realizado por escravos e bárbaros conquistados (sem governos organizados), dos quais a "inferioridade de virtudes" justificava sua submissão. Identificava-os, com isso, à condição de "escravidão natural", ao mesmo tempo em que condenava a escravização daqueles que não eram escravos por natureza (cidadãos que poderiam ser escravizados por dívida, por exemplo). Associava, ainda, a aquisição de escravos a uma espécie de caçada, anotando a importância da guerra para a vitalidade dos impérios, que em tempos de paz arriscavam-se à decadência ${ }^{20}$.

De acordo com Ellen Wood, a justificativa filosófica da escravidão sustentavase na idéia de uma divisão natural das capacidades humanas. Tanto Aristóteles e

${ }^{20}$ ARISTÓTELES. A política. São Paulo: Lafonte, 2012. p. 22-24. 
Platão na Grécia, quanto Cícero, em Roma, defendiam que aqueles dotados da força da razão sobre as paixões animalescas deveriam governar, ao passo que os despossuídos de tais faculdades deveriam ser governados, o que fazia estender a virtude daqueles sobre esses. Estabelecia-se, com isso, uma ordem natural, baseada na utilidade recíproca entre dominante e dominado ${ }^{21}$.

Mais especificamente, os pensadores e ideólogos da Grécia e Roma Antiga, observa Nikolai Karataev, consideravam que essa condição de liberdade e governo era reservada aos nativos, ao passo que o trabalho físico cabia aos prisioneiros de guerra e a maior parte dos estrangeiros. Na Grécia os principais filósofos que se dedicaram ao tema da economia sustentavam posições semelhantes, como Aristóteles, Xenofonte e Platão. Em Roma, além de Cícero, as obras dos chamados "escritores agrícolas", como Catão, Varrão e Columela, embora apresentassem nuances que marcavam seu tempo, tinham conteúdos parecidos. Baseavam-se todos na importância da agricultura como fundamento da economia, desprezando a atividade manufatureira e o comércio ${ }^{22}$.

Com efeito, as únicas profissões de um membro da elite só poderiam ser a agricultura e a guerra, não raro, combinadas $^{23}$. Assim, no comando do campo e da guerra, a elite da Antiguidade conduzia sua economia, de um lado consumindo a força de trabalho no lido árduo do sistema de plantações, de outro, repondo-a com a guerra. Se houve no princípio de Roma uma considerável classe de camponeses, anota Ellen Wood, essa foi rapidamente engolida pelo mecanismo de guerra, que os transformou em soldados e os substitui no campo pela força de trabalho cativa ${ }^{24}$.

As próprias palavras servi e mancipium, que designavam a idéia de trabalho escravo em Roma, derivam de termos relativos à guerra. Sua etimologia e significado estão registrados, inclusive, no Digest - compêndio de leis publicado por Justiniano,

\footnotetext{
${ }^{21}$ WOOD, Ellen Meiksins. Citzens to lords. Nova York: Verso, 2008. p. 130-132.

${ }^{22}$ KARATAEV, Nikolai. et all. Historia de las doctrinas econômicas. México: Editorial Grijalbo, 1964. p. 21-43.

${ }^{23}$ Ibidem.

${ }^{24}$ WOOD, Ellen Meiksins. Op. Cit. 2008, p. 115.
} 
no século VI. Servi se refere às pessoas poupadas ou "salvas" (servare) pelos capitães de guerra, enquanto mancipia à ideia de propriedade sobre aqueles tirados à força, pela força das mãos (manu capiantur), do inimigo ${ }^{25}$.

No direito romano, poderia haver basicamente três formas de trabalhadores serem agregados ao sistema escravista. A primeira derivava da Lei Civil, que permitia uma pessoa livre vender-se ou oferecer-se como escrava. As duas outras estavam relacionadas à Lei Comum Popular, na qual os escravos poderiam vir dos contingentes cativos de guerra ou da reprodução natural - filhos de escravos. Para Keith Bradley, as duas últimas formas eram certamente as mais importantes para o crescimento da população escrava. Observando a polêmica entre os estudiosos sobre a prevalência de uma sobre a outra, Bradley aponta para o acordo acadêmico geral de que o aumento da população escrava pelo influxo das conquistas de guerra predominou durante o período expansionista da República, ao passo que o crescimento natural teve maior importância nos tempos de paz do Império ${ }^{26}$.

O que se imagina aqui é que esse curso histórico representa a crise e a transformação de um organismo social baseado na expansão sobre outros, dependente da força de trabalho nascida de outras sociedades. Sua existência condicionava-se, a princípio, ao crescimento, sobretudo a uma taxa de crescimento suficiente para sustentar o centro e a fronteira dessa expansão, isto é, necessariamente a uma razão cada vez maior.

Punha-se, assim, em uma dinâmica de reprodução ampliada insustentável, uma vez que continuamente precisava recompor, pela conquista, toda sua força de trabalho. Crescia não apenas para expandir-se, mas, sobretudo, para sustentar o já conquistado e, dessa maneira, a própria conquista. Nas proporções que essa dinâmica assumia, a conquista tornava-se paulatinamente inviável e o afluxo de trabalhadores tendia ser substituído pela reprodução interna.

\footnotetext{
${ }^{25}$ BRADLEY, Keith R. On the Roman slave supply and slavebreeding. Slavery et Abolition. Reino Unido. 8:1, 42-64. 2008. p. 45.

${ }^{26}$ Ibidem. p. 42-44.
} 
Na verdade, o exposto constitui uma tese clássica. Segundo Kyle Harper, tratase da "tese da conquista" e do declínio da conquista, que levou a transição da antiguidade ao feudalismo e a qual parecem convergir as interpretações marxistas e weberianas. Seja devido às pressões sociais decorrentes do aumento do "nível de exploração do trabalho", seja o esgotamento da possibilidade das conquistas de guerra - a exaustão das populações a serem conquistadas - a sociedade antiga modificou-se no sentido da transformação de escravos em servos camponeses ${ }^{27}$.

Cabe salientar, no entanto, que muitos revisionistas, incluindo Harper, esforçam-se na crítica a essa tese, procurando compreender as mudanças da antiguidade com base em modelos que fazem uma leitura das leis da oferta e da demanda entre diferentes formas de trabalho - livre e não livre, reproduzido internamente ou emerso de formações sociais externas ${ }^{28}$. De todo modo, a interpretação do declínio da conquista e de suas conseqüências sociais permanece, nesta monografia, como a principal explicação para a transformação do modo de produção antigo ao modo de produção feudal.

Nesse movimento, a sociedade antiga constituiu os elementos que levariam a seu ocaso. $\mathrm{Na}$ impossibilidade de incorporar trabalhadores pela guerra, tornou-se imprescindível a reprodução interna. Para tanto, era preciso elevar e modificar as condições de reprodução da força de trabalho, o que implicava a constituição de famílias e algum grau de preocupação com a infância, a saúde e a segurança dos trabalhadores.

Enquanto havia margem para expansão, os trabalhadores não detinham qualquer tipo de direito e eram encarados como objetos perfeitamente substituíveis. Como assinala Perry Anderson, eram considerados verdadeiros instrumentos, os instrumentum vocales - da mesma categoria dos animais, os instrumentum semivocales, e das ferramentas, os instrumentum mutum. Não havia, acima de tudo,

\footnotetext{
${ }^{27}$ HARPER, Kyle. Slavery in the late Roman world - AD 275-425. Nova York: Cambridge University Press, 2011. p. 145-162.

${ }^{28}$ Ibidem.
} 
qualquer motivação ao aumento de produtividade, e, assim, à reprodução dos trabalhadores, praticamente paralisando o progresso técnico. E isso valia mesmo para o trabalho livre, cujos custos de reprodução eram mantidos baixos pela grande disponibilidade de mão de obra escrava ${ }^{29}$.

É somente no final da República - no momento, portanto, em que a extensão territorial de Roma atingia seu ápice - que a vernae, população de escravos nascida no domínio dos senhores, começou a ganhar importância como elemento econômico, como força de trabalho. A obra dos chamados escritores agrícolas - que tratavam de técnicas agrícolas - é um interessante testemunho disso.

Para Peter Brunt, "De agri cultura”, escrita por Catão nos últimos séculos da República, indica a preferência dos fazendeiros romanos pela compra de escravos em detrimento de sua reprodução, uma vez que esse fator nem chega a ser mencionado no livro. Ao contrário, "De res rústica", escrita por Columella, já no Império, atribuía maior importância ao cuidado com os trabalhadores escravos, como melhores acomodações e a prática de recompensar as mães escravas, as ancillae, pelo seu número de filhos ${ }^{30}$.

Segundo Eric Roll, Columella, seguido por Plínio, representava em seus escritos o próprio questionamento da escravidão como algo natural na economia. Ao contrário de seus predecessores e dos filósofos gregos, que repetiam argumentos na justificação da escravidão, Columella, preocupado com questões técnicas, passou a enxergar a escravidão como ineficiente de maneira geral. É preciso lembrar ainda, continua Roll, que seus escritos refletiam o contexto do declínio da conquista e, assim, do suprimento renovado de escravos, mostrando que as novas concepções econômicas evoluíam ao passo do desenvolvimento material da antiguidade ${ }^{31}$.

\footnotetext{
${ }^{29}$ ANDERSON, Perry. Passages from antiquity to feudalism. Londres: NLB, 1974. p. 24-26.

${ }^{30}$ BRUNT, Peter Astbury. Italian manpower - 225 B.C-14 A.D. Nova York: Oxford University Press, 1971. p. 707.

${ }^{31}$ ROLL, Eric. A history of economic thought. Londres: Faber and Faber, 1965. p. 37.
} 
Para Ste. Croix, o declínio dos contingentes cativos forçou uma grande transformação econômica no mundo Antigo, Greco-Romano. Antes de tudo, a necessidade da reprodução interna fez com que paulatinamente a escravidão fosse substituída por um regime de trabalho mais próximo da servidão medieval, baseado em trabalhadores terra-tenentes, os chamados coloni ${ }^{32}$.

Vale dizer que a maior parte dos trabalhadores escravos e livres estava espalhada no campo e, apesar do esplendor das cidades, essas eram a mera cede do poder central, tendo irrelevante importância econômica. Por isso, toda transformação social que ocorria, ocorria no campo. O modo de vida urbano e a urbanização modernos, que este trabalho enfoca nos capítulos seguintes, guarda nenhuma relação com as cidades da antiguidade.

Expandir a população escrava pelo crescimento natural exigia a formação de famílias e, assim, uma maneira diferente de acomodar os trabalhadores. Pode se dizer, uma maneira diferente de habitação trabalhadora. Antes alojados em barracões coletivos que separavam homens e mulheres, os escravos, então, passaram a ser alojados em cabanas familiares ${ }^{33}$.

Além disso, como o cuidado com crianças demandava também uma certa quantidade de trabalho - trabalho reprodutivo -, grupos de trabalhadores eram poupados das tarefas do campo e destacados para a tutela de crianças ${ }^{34}$. Bradley, em um meticuloso estudo das epígrafes do Corpus Inscriptionum Latinarum (CIL) coleção de inscrições em lápides da Roma Antiga -, mostra a importância que tutores de crianças escravas tinham, pois eram citados com certa freqüência, especialmente nas inscrições do período do Império. Tal função caracterizava uma preocupação dos senhores com a reprodução dos trabalhadores e podia ser desempenhada pelos pais

\footnotetext{
${ }^{32}$ DE STE. CROIX, Geoffrey Ernst Maurice. Op. Cit. 1981. p. 228-231.

${ }^{33}$ Ibidem. p. 228-231.

34 Ibidem. p. 228-231.
} 
da criança, por outras mulheres ou por outros homens, os nutritores ou paedagogi, e até pelos próprios senhores ${ }^{35}$.

Consequentemente, continua Ste. Croix, por um imperativo econômico, a classe de trabalhadores escravos experimentou uma elevação em suas condições de reprodução. Entretanto, a classe imediatamente superior, a dos trabalhadores livres, viu-se submetida a um maior grau de exploração, de certo modo, a compensar o aumento dos custos da escravidão. Com efeito, pressões sociais e políticas se intensificaram a ponto de gerar crises severas na sociedade romana ${ }^{36}$.

De acordo com Charles Whittaker, ambas as classes de trabalhadores chegaram mesmo a se fundir. Recorrendo a cronistas do Baixo Império, o autor aponta como os trabalhadores livres e escravos passaram a ser assimilados a uma classe única de "semi-servos": os coloni, anteriormente mencionados. O elo entre essa espécie de proto-servidão e a servidão medieval passaria, de alguma maneira, pela relação que essa transformação guardava com desintegração do poder central de Roma ${ }^{37}$.

No limite, isso representava a própria transformação das relações de produção e do modo de produção antigo, tendo efeito sobre a regulação social centralizada da antiguidade e, assim, sobre seus aspectos políticos e de classe. A preocupação com o suprimento de força de trabalho deixava a esfera da alta política, da política de guerra e de conquista, que dependia, por isso, de uma estrutura social extremamente centralizada, para se tornar um assunto essencialmente relacionado à economia doméstica. A reprodução dos trabalhadores, cujos custos eram legados a eles mesmos por meio do cultivo de subsistência da terra, demandava mais o improviso dos senhores em manter os seus domínios - de maneira descentralizada, portanto do que a agência de um governo central.

\footnotetext{
${ }^{35}$ BRADLEY, Keith R. Op.cit. 2008. p. 56-58.

${ }^{36}$ DE STE. CROIX, Geoffrey Ernst Maurice. Op. Cit. 1981. p. 228-231.

${ }^{37}$ WHITTAKER, Charles R. Circe's pigs: from slavery to serfdom in the later Roman world. Slavery et Abolition. Reino Unido. 8:1, 88-122. 1987. p. .
} 
Para Courtenay Stevens, no final do Baixo Império, o latifúndio romano se reduzia a uma unidade feudal. Antes cultivados por grupos de escravos, comprados a preços baixos, os campos, com a falência do influxo desses, passaram a ser trabalhados por semi-servos, os coloni. Dessa unidade, os senhores extraiam seus próprios impostos, retendo parte da produção camponesa como renda. Administravam toda a vida campesina, controlando até mesmo as atividades religiosas de sua população, com a provisão de bispados próprios e assegurando que todos seguissem sua versão do credo cristão. Os trabalhadores, por sua vez, sentiam uma melhora, ainda que pequena, em sua condição de vida, devido à transformação econômica e ao alívio dos impostos que se dirigiam à manutenção do decadente organismo central de Roma $^{38}$.

No argumento de Arthur Morton, uma vez que a força de trabalho escrava sempre falhou em ser reproduzida como tal, quando a expansão territorial de Roma atingiu sua amplitude máxima, o declínio era inevitável e foi mascarado pela exploração dos coloni. Progressivamente abandonadas pelo poder central, as províncias, como a Britânia, constituíram seus próprios governos e acabaram por se tornar reinos independentes ${ }^{39}$.

Segundo Michael Postan, às vésperas das invasões germânicas, a sociedade rural romana já apresentava muitos dos elementos que caracterizaram a servidão medieval. Os escravos já cultivavam a terra em talhões individualizados e os cultivadores livres faziam o mesmo como "coloni". Os cidadãos romanos, por sua vez, estratificados por relações de poder, deram amplitude, no baixo Império, a já estabelecida prática de "recomendação". Por meio desses votos de recomendação, inferiores na hierarquia romana sujeitavam-se a seus superiores na forma de clientela

\footnotetext{
${ }^{38}$ STEVENS, Courtaney Edward. Agriculture and rural life in the later Roman Empire. In: POSTAN, Michael M. Cambridge Economic History of Europe. Vol I - The agrarian life of the middle ages. Londres: Cambridge University Press, 1966. p. 115-122.

${ }^{39}$ MORTON, Arthur Leslie. A People's history of England. Londres:Lawrence \& Wishart, 1989. p. 14-16.
} 
e patronato, instituindo as obrigações e os vínculos da vassalagem e da suserania, tão marcantes no feudalismo ${ }^{40}$.

Ainda, de acordo com o autor, o constructo social germânico não era incompatível com esse desenvolvimento. Suas relações sociais já comportavam as práticas de "recomendação", a escravidão e, certamente, suas transformações. Isso, de certo modo, confronta as teses de transição que se baseiam em uma mescla das relações de produção antigas (romanas) e tribais (germânicas), como a apresentada por Perry Anderson.

Para Anderson, a transição constituiu uma síntese entre dois modos de produção que se dissolviam. Na sua exposição, contudo, essa síntese parece não convergir de um processo dialético, a ponto de o próprio autor considerar um dualismo a coexistência desses modos de produção. Tal dualismo, continua Anderson, seria superável, portanto, somente por meio de uma verdadeira síntese dialética - como Marx a define -, e não por uma simples justaposição ou mistura ${ }^{41}$.

É nesse sentido que se procura mostrar a importância de uma leitura da reprodução da força de trabalho como elemento da dialética social e do processo histórico, aqui em um breve exercício sobre a antiguidade. Como força produtiva, os trabalhadores são a base de qualquer produção. Uma vez que seu suprimento estava esgotado, tornou-se vital sua reprodução. Tal necessidade, de certo modo até então inusitada, operou uma gigantesca transformação da sociedade antiga e das formações sociais que dela passavam a fazer parte.

Para usar uma metáfora coetânea, a cabeça dourada da antiguidade caiu à falência de seus pés de barro. Na hipótese que aqui se defende, as crises políticas da antiguidade, seus conflitos de classe e suas fraquezas em face de aspectos circunstanciais, como doenças, catástrofes e invasões... repousavam sobre sua debilidade estrutural, relativa à reprodução da força de trabalho.

\footnotetext{
${ }^{40}$ POSTAN, Michael M., The medieval economy and society. Londres: Penguin, 1975. p. 90-91.

${ }^{41}$ ANDERSON, Perry. Op. Cit. p. 126-129.
} 
Trata-se de uma tentativa de compreender a crise dos mais altos assuntos com base em um dos seus mais cotidianos elementos. É também uma maneira dialética de compreender essa transformação social do mundo antigo, na qual a servidão feudal não é a superação da escravidão, como uma invenção que suplanta outra, mas sim a evolução dos antagonismos postos por esta, por sua insustentabilidade. O feudalismo nasce no âmago da sociedade antiga. 


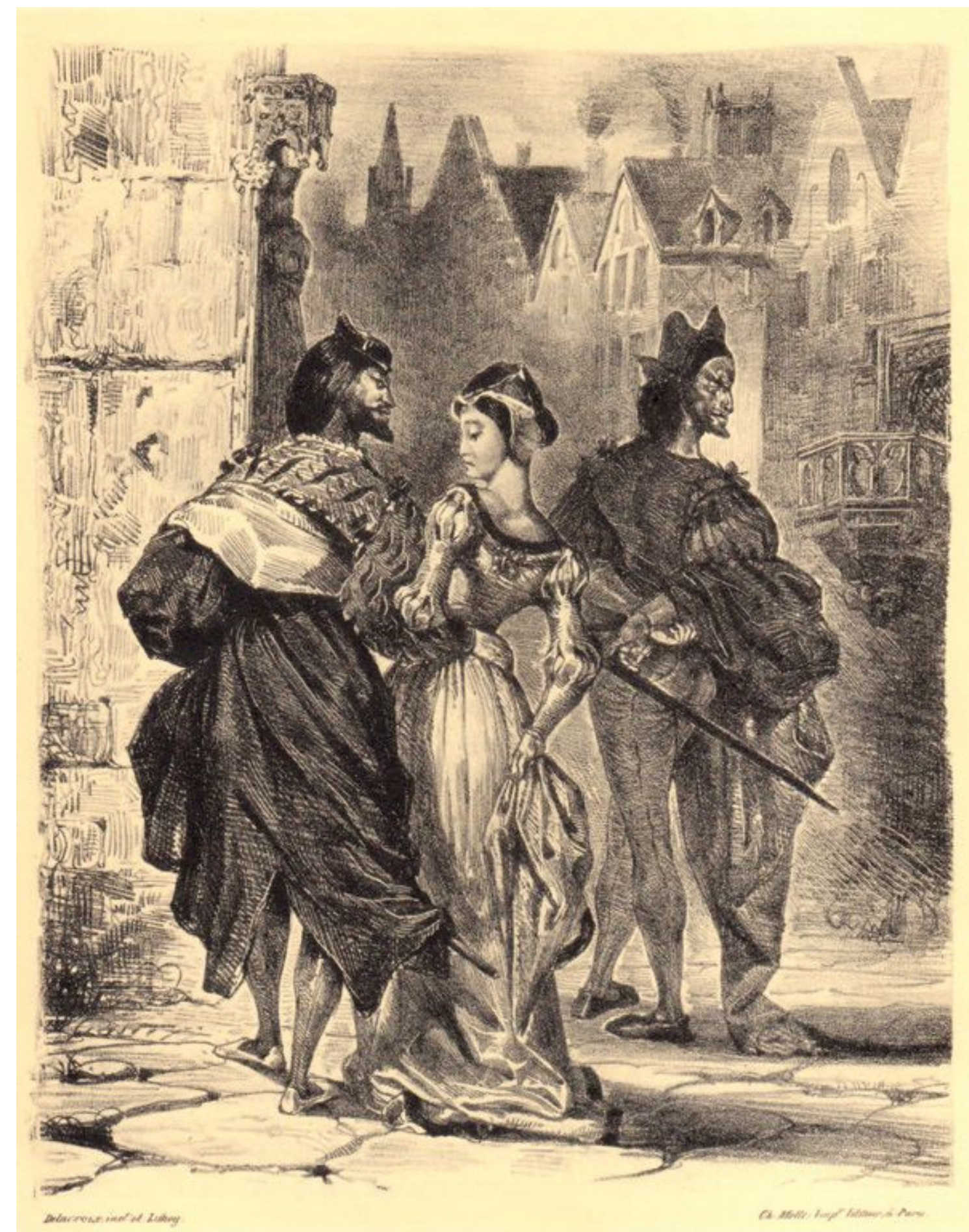

FAUST: My little lady, may I offer you My arm to see you home?

Fausto. Eugene Delacroix, 1828. Disponível em oldbookillustrations.com 


\subsection{Da servidão ao trabalho assalariado}

A sociedade que emergia da crise da antiguidade o fazia com um novo elemento: internalizava a reprodução da força de trabalho. Assenta-se nisso a diferença básica entre a escravidão e a servidão, entre o modo antigo e o feudal de produção. No primeiro não há, ou pouco importa, a reprodução da força de trabalho, ao passo que, no segundo, isso foi garantido por meio da posse da terra, com instituições que duraram séculos.

Tal persistência e suas forças antagônicas, transformadoras, foram objetos de um extenso e rico debate nos círculos marxistas, tendo, muitas vezes, atravessado suas fronteiras. Protagonizada por autores como Maurice Dobb, Paul Sweezy, Rodney Hilton e, mais tarde, Robert Brenner e Guy Bois, essa discussão constitui o panorama teórico e histórico sobre o qual este subcapítulo se estrutura e, por isso, será preliminarmente apresentada.

Em suma, o ponto do debate que se quer destacar diz respeito ao papel do mercado na dissolução do feudalismo frente à subsistência característica da economia feudal. Trata-se de questão essencial para uma compreensão dialética da transição entre feudalismo e capitalismo e que, aqui, será percorrida buscando-se sempre uma relação com a reprodução dos trabalhadores e seu vínculo com a terra.

A princípio, no feudalismo, os trabalhadores camponeses produziam para o sustento de seus senhores e para seu próprio por meio do cultivo da terra e da extração das florestas. Ainda que fossem muito variadas as formas jurídicas e institucionais associadas à servidão, Rodney Hilton considera que essas multiplicidade e ambigüidade são desnecessárias do ponto de vista teórico, sendo derivadas principalmente da pesquisa histórica não marxista.

Para Hilton, a essência da servidão estava no modo como acontecia a transferência de excedente dos trabalhadores camponeses e seus senhores, e, para ser mais preciso, no porque dessa transferência acontecer de maneira específica. Ao 
contrário das formas capitalistas - postuladamente livres -, a transferência dos camponeses a seus senhores era necessariamente forçada, pois os trabalhadores detinham a posse efetiva dos meios produtores de subsistência ${ }^{42}$.

Em sua definição, a distinção entre o trabalho capitalista e o feudal funda-se na espontaneidade ou na obrigação da transferência, mas também na posse ou não dos meios de subsistência. Se a obrigação, a transferência forçada, é algo que igualmente caracteriza o trabalho escravo, então, a qualidade distintiva do trabalho servil deve ser mais específica e recai, portanto, no segundo elemento de sua definição. Com efeito, não é algo tão longe da conceituação de Hilton imaginar que diferenciação do trabalho servil está justamente na maneira como sua reprodução era realizada, a dizer, por meio da posse da terra.

De modo geral, essa posse estava associada a basicamente dois tipos de terreno. Os primeiros eram as terras comunais - florestas, prados, brejos... -, de onde os camponeses extraiam caça, lenha, frutos, ervas, mel, além de outros víveres e matérias-primas. Os segundos eram os talhões de terra cultiváveis em que as famílias camponesas se estabeleciam, os chamados mansos servis. Ambos os tipos de terreno faziam parte do domínio de um senhor, que também possuía suas próprias porções de terra arável, os mansos senhoriais, trabalhados pelos camponeses na forma de renda.

Nesse universo, a produção era predominantemente pautada pelo consumo imediato. Como assinala Georges Duby, o excedente dos camponeses devido a seus senhores poderia tomar a forma de quantias em espécie ou mesmo em dinheiro, mas isso era muito pouco relevante nessa economia e, especialmente no início da era carolíngia, o principal tipo de obrigação consistia nas prestações em trabalho, focadas, assim, no consumo direto do enfiteuta ${ }^{43}$.

\footnotetext{
${ }^{42}$ HILTON, Rodney. Introdução ao debate sobre a transição do feudalismo ao capitalismo. In: SWEEZY, Paul et al. A transição do feudalismo para o capitalismo. Rio de Janeiro: Paz e terra, 1977. p. 15.

${ }^{43}$ DUBY, Georges. Economía Rural y vida campesina en el occidente medieval. Barcelona: Ediciones Península, 1973. p. 60.
} 
A princípio, os senhores buscavam obter tudo o que necessitavam de seus próprios domínios. Evidência disso é o que comenta Arthur Morton sobre os senhores que passavam boa parte do ano em visita a seus vassalos para o consumo, in loco, de seus tributos ${ }^{44}$. A concessão da terra aos trabalhadores, por sua vez, tinha o propósito, segundo Duby, de garantir a subsistência dos trabalhadores e livrar a classe dominante desse encargo. Assim, os domínios senhoriais, os feudos, constituíram-se como unidades produtivas descentralizadas e muito independentes ${ }^{45}$.

A verdade é que, com a queda do organismo centralizado de Roma, essas unidades não podiam depender de um sistema econômico altamente interligado. A produção de valores de uso se mantinha pela ausência de um sistema comercial ou tributário de maior alcance territorial, sendo restringido esse âmbito ao mínimo e eventual excedente produtivo. Tratava-se, na compreensão de Perry Anderson, de uma "economia natural", em que o trabalho e seus produtos não eram, na essência, mercadorias ${ }^{46}$. Esse entendimento também está próximo do trabalho referencial de Henri Pirenne, para quem a idade média constituía uma "economia sem mercados"

Na realidade, a idéia de uma economia auto-suficiente, em oposição a uma economia de trocas, caracteriza muitas das definições de feudalismo. De acordo com Maurice Dobb, essa foi a acepção corrente entre grande número dos historiadores e, especialmente, entre os historiadores marxistas, a exemplo do influente Mikhail Pokrovsky, para quem o feudalismo era uma economia que tinha como cerne o consumo $^{48}$. Produzindo valores de uso dentro de si mesmo, o feudalismo era, aparentemente, tão bem resolvido em seu interior que alguns autores, como Paul

\footnotetext{
${ }^{44}$ MORTON. Arthur Leslie. Op. Cit. 1970. p. 59.

${ }^{45}$ DUBY, Georges. Op. Cit., 1973 . p. 65.

${ }^{46}$ ANDERSON, Perry. Op. Cit., 1974. p. 147.

${ }^{47}$ PIRENNE, Henri. Medieval cities: their origins and the revival of trade. Princeton: Princeton University Press, 1946. p. 47.

${ }^{48}$ DOBB, Maurice. Studies in the development of capitalism. Londres: Routledge, 1946. p. 34-35.
} 
Sweezy ${ }^{49}$, tomam como necessária a introdução de causas externas para explicar a dialética feudal e, assim, a transição do feudalismo ao capitalismo.

A partir da segunda metade do século XX, completa Dobb, reuniram-se evidências de que o mercado teve maior importância na idade média européia do que suposto $^{50}$. Apesar disso, antes de seu colapso, o feudalismo deve ser compreendido, sublinha Hilton, em um contexto em que a maior parte do produto era retido fora do mercado pelo consumo das famílias camponesas, até mesmo devido ao seu peso quantitativo e considerando que essa era a essência de seus meios de reprodução ${ }^{51}$. Nas discussões que seguiram, entretanto, o fundamental do feudalismo estava menos na diferença entre economia de troca e economia natural do que no conceito de um sistema de produção cujo excedente tinha um ciclo curto na acumulação.

Assim queira-se, cerrada em um circuito de produção e de consumo imediato, a sociedade feudal não lidava bem com seu próprio crescimento. $O$ excedente produtivo era quase sempre desperdiçado. Os estudos estimam que os senhores extraiam mais de $50 \%$ da produção campesina, mas apenas $5 \%$ era reinvestida. Boa parte era torrada no consumo ostentoso e em dispendiosas campanhas militares ${ }^{52}$. Quando passível de ser cristalizado, o excedente era imediatamente entesourado em objetos sem valor instrumental, mentalidade a qual, como observa Braudel, mesmo os camponeses estavam submetidos ${ }^{53}$.

Esse excedente era, por isso, muito deficientemente absorvido e distribuído no processo de reprodução ampliada. $\mathrm{O}$ simples entesouramento do excedente ou 0 consumo com fim de liquidá-lo não retornavam à produção os ganhos sobressalentes, gerando, fatalmente, um descompasso entre o produzido e o consumido.

\footnotetext{
${ }^{49}$ SWEEZY, Paul. Uma Tréplica. In: SWEEZY, Paul et al. A transição do feudalismo para o capitalismo. Rio de Janeiro: Paz e terra, 1977. p. 104-105.

${ }^{50}$ Ibidem.

${ }^{51}$ HILTON, Rodney. A crisis of feudalism. Past \& Present. Reino Unido. No. 80. 3-19. 1978. p. 12.

52 BRENNER, Robert. Agrarian class structure and economic development. Past \& Present. Reino Unido. No. 70. 30-72. 1976. p. 48.

53 BRAUDEL, Fernand. Civilização material, economia e capitalismo: séculos XV-XVIII. V. II, o jogo das trocas. São Paulo: Martins Fontes, 2009. p. 43.
} 
De tal maneira, o crescimento populacional e do consumo levou a uma pressão sobre o campo e sobre o modo tradicional de produção. Como observa Hilton, tal funcionamento serviu de base para uma interpretação "ecológica" da crise do feudalismo, da qual Michael Postan foi um dos principais expoentes ${ }^{54}$. Em seu trabalho, Postan argumenta que o cultivo extensivo da terra, com 0 consequente empobrecimento do solo, a divisão das glebas devido ao crescimento populacional e à multiplicação de famílias em núcleos domiciliares menores fizeram com que a produtividade do campo não acompanhasse a expansão da população, resultando uma crise do tipo malthusiana entre os séculos XIII e XIV ${ }^{55}$.

Terras hereditárias passaram a ser divididas e cultivadas por um número cada vez maior de famílias. Interessa notar que, apesar da expansão econômica, isso era percebido pelos camponeses como a míngua de suas fortunas - na verdade, a diminuição de suas condições de reprodução. Para evitá-la, os camponeses praticavam certo tipo de controle de natalidade, autorizando apenas alguns de seus filhos a se casarem. Tal, como assinala Georges Duby, apresentava alguma efetividade, pois a taxa de fecundidade entre famílias camponesas, em seu estudo com dados de Friburgo na Suiça do século XIV, era menor $(2,5)$ do que a de famílias que haviam abandonado o campo $(2,9)^{56}$.

Aos poucos a terra tornou-se tão escassa e valiosa que as formas tradicionais de aquisição por herança foram substituídas. Tratava-se da compra para uso posterior à morte do terra-tenente, às vezes muito antes dessa tomar efeito, e também dos dote de casamento. Curiosamente, nessa época, passou a ser muito valorizado o casamento com viúvas, cujas possessões em terra eram transmissíveis. Para Postan, o aumento da aquisição de terras por compra ou casamento e a diminuição das heranças era apenas um sinal do que chama de "fome de terra", conseqüência e

\footnotetext{
${ }^{54}$ HILTON, Rodney. Op. Cit., 1977. p. 15.

55 POSTAN, Michael M. Essays on medieval agriculture and general problems of the medieval economy. Londres: Cambridge University Press, 1978. p. 13-16.

${ }^{56}$ DUBY, Georges Op. Cit., 1973. p. 401.
} 
principal penalidade da super-população. A sociedade feudal pagava por seu crescimento com a aproximação ao limite de sua subsistência ${ }^{57}$.

Além disso, a natureza do processo produtivo fazia com que o investimento do excedente fosse mínimo e incentivava, pelo contrário, o uso intensivo de mão de obra. Para Postan, a expansão populacional deixava um número maior de pessoas para trabalhar a mesma quantidade de terra, o que, com a inviabilidade de investimentos, tornava o emprego de mais trabalhadores não apenas a única forma de incrementar a produção, mas também um meio de dar solução à aguda escassez de terra ${ }^{58}$.

As explicações de Postan e seus debatedores tornaram-se muito influentes a partir da década de 1970. Suas teses sobre a insuficiência produtiva na crise da idade média européia constituíram, de um lado, uma crítica às interpretações clássicas sobre o papel do mercado em sua paulatina dissolução- como a de Henri Pirenne -, e contribuíram, de outro, para o debate marxista sobre o tema. O ponto é que a linha argumentativa que essas explanações e debates ensejam os faz oportunos para a hipótese que aqui se quer desenvolver, a seguir apresentada.

Foi justamente em torno da insuficiência produtiva e da importância do mercado no desmantelamento da sociedade feudal - em torno, portanto, dos temas trabalhados por Postan -, que se estruturaram duas importantes discussões marxistas. A primeira delas centrou-se na polêmica entre Maurice Dobb e Paul Sweezy a respeito dos mecanismos da transição entre feudalismo e capitalismo. A segunda tratava-se da crítica direta de Robert Brenner e Gui Bois à interpretação de Postan.

Em crítica a Dobb, Sweezy defendeu que o crescimento da produção de mercadorias foi o estímulo que desestruturou o feudalismo, em um processo de duas etapas. Primeiro se sobrepôs à produção de subsistência e, em seguida, preparou o terreno para a ascensão do capitalismo ${ }^{59}$. Nesse sentido, Sweezy via explicitamente o desenvolvimento comercial como uma força externa que moldou a transição entre o

\footnotetext{
${ }^{57}$ POSTAN, Michael M. Op. Cit, 1975. p. 37.

58 Ibidem. 47-48.

${ }^{59}$ SWEEZY, Paul. Uma crítica. Op. Cit., 1977. p. 49.
} 
feudalismo e o capitalismo, aproximando-se, com isso, da interpretação de Pirenne e compreendendo como incipiente a busca de Dobb por uma dialética feudal ${ }^{60}$.

A relação com Pirenne se deve a seu argumento sobre a importância do mercado na transformação da ordem feudal. A chamada tese de Pirenne sustenta que a expansão do comércio e das rotas comerciais na Europa a partir do século XII não só acharam lugar na economia de subsistência feudal, que entrava em colapso, como também influenciaram sua gradual abertura ${ }^{61}$.

Apesar de reconhecer o crescimento do mercado como um relevante componente da transformação do feudalismo, Dobb rebateu as críticas de Sweezy insistindo no método do materialismo dialético. Isto é, para Dobb era preciso discutir o princípio motor (interno) da transformação do feudalismo. Especificamente, via a crescente super-exploração do campesinato como um fator decisivo na crise medieval, hipótese que, mais tarde, Robert Brenner desenvolveria na crítica a Postan ${ }^{62}$.

Contrapondo o argumento de Sweezy com a história específica da Inglaterra na Baixa Média, Dobb mostrou que o mercado e a intensificação das trocas monetizadas poderiam ter efeitos contrários ao declínio da servidão, essência do feudalismo. Segundo o autor, as regiões menos desenvolvidas comercialmente e com menores redes urbanas, como no norte e oeste da Inglaterra, foram as primeiras a abandonarem o sistema das prestações em trabalho, ao passo que no sudeste mais avançado houve, ao contrário, uma acentuação dessas prestações diretas ${ }^{63}$.

Na obra que originou o debate, Dobb também retoma o que Engels denominou como "segunda servidão". Tratou-se do avanço, no século XV, do comércio e exportação de grãos no Leste Europeu ao lado da paradoxal intensificação e reconversão das rendas em trabalho. Assinala também que essa foi a característica do desenvolvimento comercial russo no século XVIII, tempo em que os camponeses

\footnotetext{
${ }^{60}$ Idem. Uma tréplica. Op. Cit., 1977. p. 104-105.

${ }^{61}$ PIRENNE, Henri. Op. Cit., 1946. p. 101-102.

62 DOBB, Maurice. Uma réplica. In: SWEEZY, Paul et al. A transição do feudalismo para o capitalismo. Rio de Janeiro: Paz e terra, 1977. p. 61.

63 Ibidem. p. 61
} 
foram arduamente explorados por seus senhores com a manutenção dos vínculos da servidão $0^{64}$.

A desvinculação do afrouxamento da servidão ao crescimento do comércio foi, na verdade, o argumento recorrente dos autores que se opunham à idéia de que o mercado teria uma ação causal na queda do feudalismo. De acordo com Robert Brenner, autores como Postan e Le Roy Ladurie mostraram que, em muitos casos, longe de marcar sua dissolução, a expansão do comércio coincidiu com a reafirmação da servidão. Além do mais, as comutações - transformação da renda-trabalho em renda-espécie -, que em certo sentido o desenvolvimento comercial permitiu, como na Inglaterra do século XII, não significou a ruptura com a servidão, tanto que foi possível impô-la novamente no século seguinte ${ }^{65}$.

Isso não quer dizer, contudo, que tais interpretações não enxergavam importância na ascensão do mercado na constituição do capitalismo ${ }^{66}$. Em certo diálogo com a obra de Postan, Duby, por exemplo, percebe as cidades e os mercados urbanos como a "válvula de escape" para essa crise que assim se firmava na Europa da baixa idade média ${ }^{67}$.

Por mais isolados que fossem os domínios senhoriais, todos se conectavam entre si e a força de suas transformações os demandavam a contar cada vez mais com essa comunicação e intercâmbio. A superpopulação e o empobrecimento progressivo de um amplo setor do campesinato induziram um ciclo vicioso que levava à super exploração da terra, seu esgotamento e ao crescimento de uma massa de jornaleiros. Tal pressão demográfica e de produção paulatinamente encontravam destino nas cidades, que cresciam por imigração, e no aparato comercial, que começava ganhar abrangência e complexidade com as demandas urbanas ${ }^{68}$.

\footnotetext{
${ }^{64}$ Idem. Studies in the development of capitalism. Londres: Routledge, 1946. p. 39-41.

65 BRENNER, Robert. Op. Cit., 1976. p. 41-45.

${ }^{66}$ Ibidem. p. 53.

${ }^{67}$ DRENDEL, John et all. Crisis in the later middle ages: beyond the Postan-Duby paradigm. Bélgica: Brepols, 2015. p. 5.

${ }^{68}$ DUBY, Georges Op. Cit., 1973. p. 397, 456.
} 
Resumindo especificamente o debate marxista, Ellen Wood, afirma que a questão da importância do mercado na transição do feudalismo foi sempre uma armadilha que deixava pontos a explicar. O chamado "modelo da comercialização", como defendido por Sweezy, pressupunha a existência do mercado e de uma racionalidade capitalista que teve origem dentro da própria sociedade feudal, mas cuja constituição não era explicada. A crítica a esse modelo, como feita por Dobb e Hilton, apesar de contundente, nunca conseguiu dar uma resposta em substituição ${ }^{69}$.

Seguindo essas conclusões, o primeiro componente da hipótese aqui ensaiada é a proposição de que o mercado não era uma das causas da crise do feudalismo, mas antes um poderoso expediente acionado em sua resposta. De outro modo, podese dizer que preliminar à compreensão dos efeitos desse expediente é a investigação da necessidade que o mobilizou.

Reside aí a matéria específica do questionamento de Dobb por antagonismos internos ao processo social no feudalismo, amadurecido no debate com Sweezy. Na concepção desse último, era preciso descobrir primeiro porque o comércio engendrou um sistema de produção para troca - ou porque se tornou necessário na reprodução social -, para, então, lançar-se à compreensão dos efeitos desse sistema sobre a desintegração do modo de produção feudal ${ }^{70}$.

Esse porque, sugere Hilton, tem raízes nos desequilíbrios produtivos inerentes à economia feudal, como proposto por Postan. Para Hilton, essa visão da crise medieval, que em essência se relacionava à incapacidade do feudalismo em dar conta de seu próprio crescimento, não é incompatível com a interpretação marxista. No entendimento marxista, entretanto, há o esforço de explicitar que tal crise transcende o determinismo natural. Os ensaios no sentido dessa construção, continua o autor,

\footnotetext{
${ }^{69}$ WOOD, Ellen Meiksins. The origin of capitalism. Nova York: Verso, 2002. p. 42.

${ }^{70}$ SWEEZY, Paul. Uma crítica. Op. Cit., 1977. p. 41.
} 
iniciaram-se nos trabalhos de Dobb e culminaram na crítica direta a Postan, de Robert Brenner e Guy Bois ${ }^{71}$.

Segundo Brenner, a crise de produtividade a que se refere Postan não era simplesmente determinada por um movimento demográfico, mas sim pela característica das relações de produção. Com o poder dos senhores sobre os servos, o aumento de produtividade era conjunturalmente impedido e, mesmo, desnecessário ${ }^{72}$.

De um lado, os senhores não tinham estímulo ao emprego de métodos mais produtivos, pois tinham a sua disposição a capacidade - e o direito - de tomar parte no produto dos camponeses à porção que lhes conviessem, até abaixo do nível de subsistência. De outro, os camponeses eram controlados a ponto de não conseguirem usar suas terras e recursos eficientemente, pois não podiam arrendá-las, transformálas ou delas se desvincular ${ }^{73}$.

Com a partilha arbitrária dos ganhos da produção em favor dos senhores, os camponeses tornavam-se incapazes de recompor sua estrutura produtiva e, finalmente, eram continuamente subtraídos de seus meios de reprodução. Isso, para Brenner, levou a uma crise da acumulação campesina e, fatalmente, de sua subsistência ${ }^{74}$.

Em interlocução com a obra de Brenner e Postan, Guy Bois retomou a questão do mercado. Juntamente com as limitações de crescimento econômico próprias da pequena e tradicional produção, Bois observou que a emergência do mercado, especialmente sua expansão através dos níveis mais baixos da sociedade (diferentemente do comércio luxuoso que existia até então), era um dos aspectos mais marcantes da crise do feudalismo. Aliás, aponta com vigor que, muito anteriormente

\footnotetext{
${ }^{71}$ HILTON, Rodney. 1978 . p. 4-6.

72 BRENNER, Robert. Op. Cit., 1976. p. 48-52.

73 Ibidem.

${ }^{74}$ Ibidem.
} 
ao capitalismo, a sociedade feudal foi a verdadeira fundadora e agente da economia de mercado ${ }^{75}$.

Vale completar que o mercado, nesse caso, não era uma invenção ao acaso ou uma esfera espontânea que se desenvolvia autonomamente, mas sim um artifício que respondia a uma determinante necessidade do feudalismo. Em outras palavras: o par, subsistência e mercado, não era um dualismo, era uma dialética. Nesse sentido, John Merrington, sintetiza: uma vez desencadeados, o princípio da troca e o mercado constituíram o agente motor de todo o desenvolvimento feudal e capitalista ${ }^{76}$.

Esse é o ponto que se quer relevar na leitura desse debate, pois compreende os componentes do raciocínio dialético que aqui se deseja experimentar sobre a transição do feudalismo ao capitalismo. Qual seja: A subsistência característica da economia feudal permitia o crescimento populacional, mas não o acompanhava. $E$ isso não por uma questão ecológica, e sim pelo arranjo das relações de produção que, fundadas no consumo imediato e nos privilégios senhoriais, estruturavam-se alheias a mecanismos sofisticados de reprodução ampliada. Desse modo, a sociedade feudal demandou, como uma válvula de escape, a solução do mercado, o qual, funcionando antagonicamente, acabou por desmantelá-la.

O que se defende é que - importa grifar - esse antagonismo encontra-se justamente na premissa básica deste texto, na reprodução da força de trabalho. Isto é, se a reprodução da força de trabalho camponesa residia na produção de subsistência - na produção de valores de uso -, então, sua inviabilidade e progressiva transformação na produção de valores de troca deve ter correspondido a sua crise e modificação. Nessa dialética, o mercado tinha um efeito ambivalente sobre a reprodução da força de trabalho no declínio do feudalismo. Ao mesmo tempo em que

\footnotetext{
${ }^{75}$ BOIS, Guy. On the crisis of the Late Middle Ages. The Medieval History Journal. Vol. 1, 2. 311-321. 1998. p. 317-321

${ }^{76}$ MERRINGTON, John. A Cidade e o campo na transição para o capitalismo. In: SWEEZY, Paul et al. A transição do feudalismo para o capitalismo. Rio de Janeiro: Paz e terra, 1977. p. 175.
} 
dilapidava os meios de subsistência dos trabalhadores, apresentava-se como única alternativa de sobrevivência.

Estão aí as condições elementares para o surgimento das relações de produção capitalistas, da urbanização e da industrialização que marcaram as tão promovidas revoluções do século XVIII e XIX. Essas condições, contudo, fizeram ser sentidas muito antes, no chamado sistema Verlag e no novo regime fundiário que tomava corpo na Europa desde antes da metade do segundo milênio. $\mathrm{Na}$ análise desses novos sistemas produtivos e regimes fundiários, fica patente o efeito dúbio do mercado na desestruturação das relações de produção feudais e, por isso, sua explanação é fundamentalmente esclarecedora.

A princípio, o sistema Verlag era uma forma de organização da produção baseada no trabalho doméstico camponês. Nele, mercadores viajantes - os Verlegerarticulavam uma cadeia produtiva altamente descentralizada, ancorada no artesanato feito nos domicílios dos trabalhadores como complemento aos rendimentos do campo e envolvendo toda a família camponesa - homens, mulheres e crianças. Esses mercadores adiantavam a matéria-prima e encaminhavam os produtos intermediários de um a outro produtor até o resultado final, que era, então, comercializado pelos próprios mercadores.

De acordo com Braudel, tal sistema tinha muitas variações e estava presente em toda a Europa desde o século XIII. Na Alemanha chamava-se Verlagssytem; na Inglaterra, putting out system ou cottage industry; na França, travail à domicile ou à façon. Quando o mercador envolvia corporações de ofício ou pequenas oficinas, chamava-se, especificamente, Luftkauf. Normalmente, tratava-se da produção relacionada ao artesanato doméstico, como peças de vestuário, cestos, cordas, ferramentas e utensílios, mas se estendia também a diversos ramos da indústria, como à tecelagem e até à produção de navios ${ }^{77}$.

\footnotetext{
${ }^{77}$ BRAUDEL, Fernand. Op. Cit. 2009. p. 276.
} 
Segundo Morton, sob os moldes desse sistema, a produção de tecidos na Inglaterra do século XVI já alcançava uma considerável escala de exportação. Seus agentes já tinham grande influência política e eram retratados como heróis em romances inovadores, como os de Thomas Deloney. Esses mercadores começaram com o comércio de panos e, aos poucos, controlaram toda cadeia produtiva. Compravam a lã crua e repassavam às famílias de cardadores, em seguida às casas de fiadores, aos tecelões, aos pisoteadores, aos tingidores, aos aparadores... lucrando em cada operação e comercializando o produto final ${ }^{78}$.

Apesar de muitas vezes encarados como visionários e cuja criatividade realizou uma transformação da economia, os mercadores, na verdade, simplesmente se aproveitavam dos imperativos conjunturais da crise do feudalismo, em especial da crise de reprodução dos trabalhadores. Braudel mostra como essa pré-indústria era suplementar ao sustento dos camponeses. Estava associada à produção rural e "andava de mãos dadas com a pobreza", constituindo o que chamou de "indústria providência". Isto é, tratava-se mais de uma saída ao solapamento dos meios de reprodução da classe trabalhadora do que da engenhosidade burguesa ${ }^{79}$.

Para Marx, a própria comutação da renda-trabalho em renda-espécie implicava uma intrínseca relação entre a agricultura e a produção doméstica articulada pelos mercadores. Apesar de, a princípio, essa relação permitir maior liberdade aos camponeses na administração de seu tempo de trabalho, não os tornava produtores independentes. Ao contrário, os deixava ainda mais sujeitos, precisamente devido à força das circunstâncias, que ameaçavam seus meios de subsistência ${ }^{80}$.

$\mathrm{Na}$ Inglaterra, afirma Dobb, as dificuldades dos camponeses impulsionaram e mantiveram por muito tempo o sistema de putting out. A persistência de um grande número de pequenos camponeses ainda vinculados à terra, mas já incapazes de extrair totalmente dela seus sustentos, foi um importante fator no crescimento desse

\footnotetext{
${ }^{78}$ MORTON. Arthur Leslie. Op. Cit. 1970. p. 132.

${ }^{79}$ BRAUDEL, Fernand. Op. Cit. 2009. p. 266.

${ }^{80}$ MARX, Karl. Capital. Vol I. Londres: Penguin, 1990. p. 930-932.
} 
tipo de indústria descentralizada e dessa espécie de "semi-proletariado". Dessa forma, a produção em fábricas e manufaturas só ganhou extensão mais tarde, com a desvinculação dos trabalhadores do solo e sua conseqüente mobilidade ${ }^{81}$.

Foi essa mesma conjuntura, entretanto, que paulatinamente expulsou a população do campo e criou uma mobilidade de massas sem precedentes. Como em um movimento de duas frentes, o mercado - que complementava os rendimentos campesinos, mas, sobretudo, crescia com base neles -, também pressionava o campo no sentido da transformação de toda produção em mercadorias e da terra em propriedade privada, deixando os trabalhadores, que não podiam comprá-la, realmente sem meios de subsistir.

Era o momento histórico dos chamados Cercamentos. No contexto específico da Inglaterra do século XVI, esse movimento significava a transformação de grandes parcelas do campo em propriedades dedicadas à criação de ovelhas, cuja lã abastecia a já consolidada indústria têxtil.

Não à toa, a existência e crescimento da indústria doméstica estavam relacionados ao movimento maior dos cercamentos e da revolução na agricultura. Conforme Karl Polanyi, a indústria doméstica cresceu no mesmo ritmo que os cercamentos, empregando pequenos camponeses e a população rural excluída do manejo da terra ${ }^{82}$.

A narrativa de Thomas More, em "Utopia", é, como anota Morton, um depoimento preciso e contundente desse contexto. Nela, More associava a pobreza e a situação caótica em que se encontrava a Inglaterra pré-revolucionária à transformação produtiva da terra (de subsistência à produção de mercado) ${ }^{83}$. Os responsáveis por essa bagunça, observou um de seus personagens, eram as ovelhas... Aqui vale uma extensa citação direta:

\footnotetext{
${ }^{81}$ DOBB, Maurice. Op. Cit. 1946. p. 230-231.

82 POLANYI, Karl. The Great Transformation. Boston: Beacon press, 2001. p. 36.

${ }^{83}$ MORTON, Arthur Leslie. The English utopia. Disponível em:

https://www.marxists.org/archive/morton/1952/english-utopia/index.htm. Acesso em: 05-08-2020.
} 
"Esses animais são, habitualmente, bem mansos e pouco comem. Mas disseram-me que, no momento, mostram-se tão intratáveis e ferozes que devoram até os homens, devastam os campos, casas e cidades. Efetivamente, em todos os pontos do reino onde se obtém a mais fina lã, portanto a mais preciosa, os senhores, os nobres e até santos abades, não se contentam mais com os rendimentos e o produto que seus antepassados costumavam retirar de seus domínios. Não Ihes é mais suficiente viver na preguiça e nos prazeres; estes homens, que nunca foram úteis à sociedade, querem ser ainda, positivamente, nocivos. Não deixam nenhuma parcela de terra para ser lavrada; toda ela transformou-se em pastagens. Derrubam casas, destroem aldeias e, se poupam as igrejas é, provavelmente, porque servem de estábulos a seus carneiros. Essas excelentes pessoas transformam em deserto as habitações, e tudo que era cultivado; como se as florestas e as terras reservadas à caça já não prejudicassem bastante a agricultura" ${ }^{\prime 4}$.

Essa era também a queixa registrada pelos Diggers. Os Diggers ou True Levellers eram um grupo de trabalhadores sem-terra - deslocados pelos cercamentos -, que, liderados por Gerrard Winstanley, defendiam o cultivo agrícola coletivo nas terras comunais. A capa de um de seus manifestos dizia:

"Uma declaração do povo pobre e oprimido da Inglaterra, dirigida àqueles que, por toda a nação, se autodenominam, ou são chamados, senhores de terra; que começaram a derrubar ou, que por

\footnotetext{
${ }^{84}$ MORE, Thomas. Utopia. Brasília: Editora UNB, 2004. p. 17-18.
} 
medo ou cobiça, pretendem derrubar as florestas e as árvores que crescem nas terras comunais e nas terras baldias" 85 .

Essas circunstâncias eram algo como uma faca de dois gumes para a reprodução dos trabalhadores. Os cercamentos, a despontante indústria e a produção para o mercado aceleravam a espoliação dos meios de reprodução da classe trabalhadora, mas, ao mesmo tempo, constituíam a única alternativa - ou esperança de se ganhar a vida: o assalariamento.

Com a referência de uma pequena aldeia da Itália do século XVI, Braudel exemplifica essa situação. Tal aldeia - Montaldeo - havia sido comprada por mercadores ricos de Gênova e nela os camponeses eram livres, mas viviam em extrema miséria. De acordo com os registros, apenas 8 dos 54 lares da aldeia alcançavam padrões mínimos de subsistência, o restante encontrava-se em estado de fome crônica. Paradoxalmente, sua população crescia e quando as famílias se confinavam em minifúndios, precisavam dispor-se como ceifeiros assalariados em localidades distantes. Isso quando achavam trabalho, que, não raro, pagava-lhes menos do que consumiam com a própria alimentação ${ }^{86}$.

A terra, segundo Polanyi, era um elemento intrinsecamente ligada às instituições da sociedade feudal: Laços de parentesco, de vizinhança, credo e relações de produção. Subordiná-la aos requisitos de uma economia de mercado, com a comercialização e mobilização fundiária, significou nada menos do que a liquidação da sociedade feudal, iniciada no ocidente e na Inglaterra do século XIV e finalizada no curso das revoluções do século XVIII e XIX ${ }^{87}$

Essa revolução, para John Merrington, fundava-se na separação entre produção e consumo. O interessante é que sua base interpretativa e teórica já estava

\footnotetext{
${ }^{85}$ WINSTALEY, Gerrard. Digger pamphlet. Disponível em: http://www.diggers.org/diggers/declaration\%20from\%20the\%20poor\%20oppressed.htm. Acesso em: 11/01/2020.

${ }^{86}$ BRAUDEL, Fernand. Op. Cit. 2009. p. 228.

${ }^{87}$ POLANYI, Karl. Op. Cit. 2006. p. 38;187-188.
} 
plenamente formulada nos trabalhos dos economistas do século XVIII, como em Smith e Stueart ${ }^{88}$

Smith, aliás, tem uma explicação para a transição do feudalismo baseada em espécie de crise da reprodução dos trabalhadores. Para o autor de a riqueza das nações, enquanto o mercado não havia se propagado como um elemento importante na sociedade feudal, os senhores gastavam, ou permitiam gastar, grande parte do produto de seus domínios na reprodução das famílias de vassalos e servos, o que conservava seu poder sobre elas ${ }^{89}$.

Com o crescimento do mercado, os senhores passaram a consumir cada vez mais uma parte maior desse produto, para manutenção das extravagâncias que o mercado Ihes permitia. Isso fazia com o que o sustento das famílias agregadas fosse erodido, assim como, seu poder sobre elas. Para Smith, esse funcionamento deslocava, ainda, os rendimentos destinados à manutenção das famílias agregadas do campo para a massa de trabalhadores assalariados que começava a se consolidar nas cidades ${ }^{90}$.

Esse movimento era algo que ocorria sem previsão e intenção. Desenrolava-se meramente pela interação entre interesses individuais guiados pela ação desimpedida do princípio da troca, do mercado, destruindo as cadeias produtivas do campo, a autosuficiência da economia rural e gerando a "independência" dos produtores rurais ${ }^{91}$.

Mas essa transformação não acontecia sem turbulências sociais ou sem tentativas do Estado de se contrapor ou de se ajustar a ela. No fim, levou a Inglaterra à guerra civil - à Revolução de 1640 -, iniciando, especialmente depois da Restauração de 1688, o regime político e jurídico que começou a moldar as instituições capitalistas.

\footnotetext{
${ }^{88}$ MERRINGTON, John. Op. Cit. 1977. p. 171.

${ }^{89} \mathrm{SMITH}$, Adam. The wealth of nations. Livro III, cap. IV. Disponível em: https://www.marxists.org/reference/archive/smith-adam/works/wealth-of-nations/book03/ch04.htm. Acesso em: 20/01/2020.

${ }^{90}$ Ibidem.

${ }^{91}$ MERRINGTON, John. Op. Cit. 1977. p. 171.
} 
Como um esforço da antiga sociedade em se preservar, houve, a princípio, várias leis contrárias à expropriação camponesa. De certo modo, visavam à manutenção da população no campo, do modo tradicional de produção e de reprodução dos trabalhadores. Marx cita um ato de Henrique VII de 1489, que proibia a destruição de casas campesinas com menos de 20 acres de terra. Em outro ato, Henrique VIII fixou a proporção entre pastagens e terras aráveis, com o intuito de conservar o sustento dos trabalhadores. No reinado de Charles I e também sob o regime de Cromwell inúmeros atos proibiam a construção de casas com menos de 4 acres de terra a elas anexos. Contudo, a legislação não só foi inócua contra os cercamentos, como também se rendeu a eles ${ }^{92}$.

Referindo-se ao processo que acontecia na Europa de modo geral, Merrington observa que os governos legislavam em vão para impedir a mobilidade e o crescimento da população, que eram vistos como ameaça à ordem social. Mas, com a citação de Braudel, questiona: "Seria mesmo sensato suprimir a válvula de segurança indispensável à fervura do grande reino?"93.

Os cercamentos, anota Chrstopher Hill, suscitaram amplos debates na sociedade inglesa desse período. De um lado, já eram encarados nas discussões econômicas como uma forma de expandir a produção e de incorporar trabalhadores à atividade manufatureira, de outro, suas consequências sociais, sobretudo o crescente contingente de retirantes, foram a causa de grandes preocupações. Emersos das relações feudais, os chamados "sem mestres" foram vagarosamente absorvidos pela ordem capitalista que aflorava e, em muitos sentidos, estiveram na agenda da sociedade dos séculos XVI e XVII ${ }^{94}$.

Esses trabalhadores expropriados transformaram-se em correntes migratórias nunca antes vistas. Desamparados e excluídos da dinâmica produtiva, frequentemente se tornavam ladrões ou mendigos. Por vezes se refugiavam em comunidades

\footnotetext{
92 MARX, Karl. Op Cit. 1990. p. 880-885.

${ }^{93}$ MERRINGTON, John. Op. Cit. 1977. p. 189.

${ }^{94}$ HILL, Christopher. The world turned upside down. Londres: Penguin, 1975. p. 20, 39-56.
} 
silvícolas, como pode ilustrar a lenda de Robin Hood - cujas primeiras baladas datam do século XIV. Por outras, encetavam movimentos de luta por reforma agrária, consideravelmente organizados e socialmente significativos, como os Diggers. A grande maioria teve, no entanto, quando não perseguida e exterminada, as cidades como destino principal, que, como Londres, apresentaram um expressivo crescimento por volta de $1600^{95}$.

Os cercamentos, nesse sentido, significaram uma profunda transformação social. Não sendo algo restrito à Era Tudor, observa Morton, datam desde o século XIV, já com relevante intensidade, e estendem-se até o final do século XVIII. Relacionados a eventos como a dissolução da "clientela" - grupos de capangas mantidos pelos grandes nobres durante a Guerra das Rosas - e a dissolução dos mosteiros, de 1536 e 1539, os cercamentos geraram, pode-se arriscar, uma nova classe social ${ }^{96}$.

A ela foram endereçadas as mais diversas políticas, de assistência social, penais... mas cujo principal conteúdo, na realidade, tratava do disciplinamento de uma crescente força de trabalho proletária. A repressão violenta, muitas vezes mediante contrato com mercenários estrangeiros, também foi um dos expedientes a que se recorreu contra os inúmeros levantes desencadeados pelos cercamentos ${ }^{97}$.

Tais medidas apenas confirmaram uma transformação irreversível, em curso há muito tempo na crise do feudalismo e que desembocaram no capitalismo. Esse foi o processo que Marx chamou de acumulação primitiva. Por meio da espoliação dos bens da Igreja, da alienação dos domínios da Coroa e da transformação das terras comunais, dos feudos e dos territórios dos clãs em propriedade privada, conquistou-se o campo para a agricultura capitalista e criou-se uma massa de trabalhadores livres e sem direitos, que encheriam as cidades e supririam a demanda da indústria urbana ${ }^{98}$.

\footnotetext{
${ }^{95}$ Ibidem.

${ }^{96}$ MORTON, Arthur Leslie. Op. Cit, 1970. p. 140-147.

97 Ibidem.

${ }^{98}$ MARX, Karl. Op. Cit. p. 895.
} 
Apesar de Marx nunca ter usado o termo urbanização, a descrição desse processo mostra que a afluência às cidades e o surgimento das relações de produção capitalistas eram, no fundo, a mesma coisa. Chegava-se definitivamente ao capitalismo com a transformação do mais fundamental elemento da economia em mercadoria: o trabalho ${ }^{99}$. Agora alheios à subsistência do campo, os ofertantes dessa mercadoria, os trabalhadores, não tinham escolha a não ser vendê-la - na cidade. Como resume Csaba Deák: "a urbanização nada mais é do que o crescimento do proletariado" 100 .

Com isso, generalizava-se o mercado - a forma-mercadoria - como âmbito primaz da regulação da produção. O argumento específico deste trabalho é que todo esse processo tinha como essência o novo regime fundiário e suas implicações sobre a reprodução da força de trabalho. Isto é, esse processo passou a existência como efeito das necessidades dos trabalhadores, e as manteve como sustentáculo da nova ordem.

Em certo sentido, essa essência constituiu uma fórmula, cuja síntese está nas constatações e recomendações de Edward Wakefield. Wakefield foi um proeminente teórico e político inglês na conjuntura do colonialismo do século XIX. Seus trabalhos sobre a "colonização sistemática" são comparados por Marx, com certa ironia, a uma descoberta científica ${ }^{101}$. No texto de "o capital", a perspicácia de Wakefield opõe-se, anedoticamente, às desastrosas experiências de colonização que fracassaram no Novíssimo Mundo, como as do nobre inglês Thomas Peel.

No começo do século XIX, Peel articulou uma significativa quantidade de capitais, maquinário e trabalhadores assalariados para iniciar, na Austrália, uma colônia produtiva. No entanto, ao desembarcar, Peel foi abandonado por todos os seus empregados, que, diante da disponibilidade de terras sem propriedade,

\footnotetext{
${ }_{99}$ MARX, Karl. Op. Cit., 1990. p.

${ }^{100}$ DEÁK, Csaba. O processo de urbanização no Brasil: falas e façanhas. In: DEÁK, Csaba; SCHIFFER, Sueli. O processo de urbanização no Brasil. São Paulo: EDUSP, 2010. p. 16.

${ }^{101}$ MARX, Karl. Op. Cit. 1990. p. 939-940
} 
preferiram se estabelecer como produtores rurais independentes a continuar sua condição de assalariados. No humor de Marx, o Sr. Peel havia levado consigo tudo o que precisava para ser um capitalista na Austrália, só esqueceu as relações de

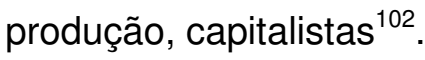

Wakefield apontou a solução para as próximas tentativas: lotear a Austrália, a preços inacessíveis aos trabalhadores. Dessa forma, para Marx, o Novo Mundo reproduziu "artificialmente" o que o Velho demorou séculos para fazer ${ }^{103}$. O "segredo" estava justamente na reprodução da força de trabalho, em separar uma de outra, em separar a força de trabalho da subsistência da terra.

Obviamente, o chamado "sistema Wakefield" não foi a base da urbanização e proletarização de todos os países. Mas a essência da expropriação dos meios de reprodução dos trabalhadores é comum a quase todos os episódios da história. E se não, o questionamento sobre como se realiza efetivamente a reprodução da força de trabalho é o cerne da pergunta que deve ser feita. Vale dizer, é a essência da indagação sobre o conteúdo material específico da constituição e da dialética de cada formação social.

Nos Estados Unidos, por exemplo, ao contrário da Austrália, as leis de cessão de terras aos imigrantes - os Homestead Acts -, ao lado da Abolição, criou, a seu modo peculiar, um diferente movimento de proletarização. Lavrando em minifúndios de solo muito pobre, os fazendeiros que colonizariam o meio oeste norte-americano, quando não diretamente expropriados, logo se tornaram subordinados ao grande capital. Esse grande capital, segundo Michel Aglietta, com o apoio do Estado e o escuso monopólio das ferrovias, das bacias hidrográficas e do mercado de terras, suplantaria toda a produção das pequenas propriedades ou dos ranchos de subsistência, sujeitando-os às relações de produção capitalistas ${ }^{104}$. Leo Huberman

\footnotetext{
102 Ibidem.

103 Ibidem

${ }^{104}$ AGLIETTA, Michel. Fases da expansão capitalista nos Estados Unidos da América. Espaço \& Debates. Ano IX, n. 28. São Paulo, 1989. p. 11-12.
} 
mostra como, após as várias leis de homestead e apesar do significativo aumento populacional, a proporção de lavradores independentes caiu de 7 para 3 em cada 10 americanos entre as décadas de 1860 e $1900^{105}$.

No caso Europa continental do século XIX, as reformas napoleônicas e benthamitas, que tinham a estruturação da propriedade privada como um dos principais pontos de sua agenda, animaram uma dinâmica urbana e de proletarização diferente da inglesa ${ }^{106}$. Tanto o é que a França é hoje um dos países industrializados menos urbanizados do mundo. O porfiriato no México, ao desintegrar as terras coletivas e camponesas, acabou com arranjos produtivos e as comunidades tradicionais - ranchos e pueblos -, levando, por fim, à Revolução Mexicana ${ }^{107}$. No Brasil, o desvirtuado regime de terras, apesar de baseado no sistema Wakefield, desembocaria em igualmente desvirtuadas formas de assalariamento e em sua característica precariedade urbana ${ }^{108},{ }^{109} \mathrm{e}^{110}$. Na China, o sistema hukou deu origem ao que Giovnni Arrighi chamou de "acumulação sem desapropriação"111 e caracteriza um dos principais pontos de investigação deste trabalho.

De todo modo, seja no "caso clássico" ou nas florescentes realidades capitalistas contemporâneas, o elo entre a estruturação do espaço e a reprodução dos trabalhadores é um componente revelador na análise da evolução de seus processos sociais. No desenvolvimento do capitalismo inglês, é desse elo que emergiu, dialeticamente e no seio da sociedade feudal, o mercado - a forma-mercadoria -, assim como sua inseparável conjuntura urbana. Nos subcapítulos seguintes, a aposta é que desse mesmo elo também surge a transformação do capitalismo, por meio do antagonismo entre o mercado e o Estado.

\footnotetext{
${ }^{105}$ HUBERMAN, Leo. Nós, o povo. São Paulo: Brasiliense, 1966. p. 177.

${ }^{106}$ POLANYI, Karl. Op. Cit., 2006. p. 182.

${ }^{107}$ BARBOSA, Carlos Alberto Sampaio. A Revolução Mexicana. São Paulo: Unesp, 2010. p. 36-44.

108 MARTINS, José de Souza. O cativeiro da terra. São Paulo: Editora Contexto, 2010. p. 195-196.

109 PRADO, Caio. A revolução brasileira. São Paulo: Brasiliense, 1966. p. 54-57.

110 ITIKAWA, Luciana. Mulheres na periferia do urbanismo. Buenos Aires: CLACSO, 2015.

${ }^{111}$ ARRIGHI, Giovanni. Adam Smith em Pequim. São Paulo: Boitempo, 2008. p. 366.
} 


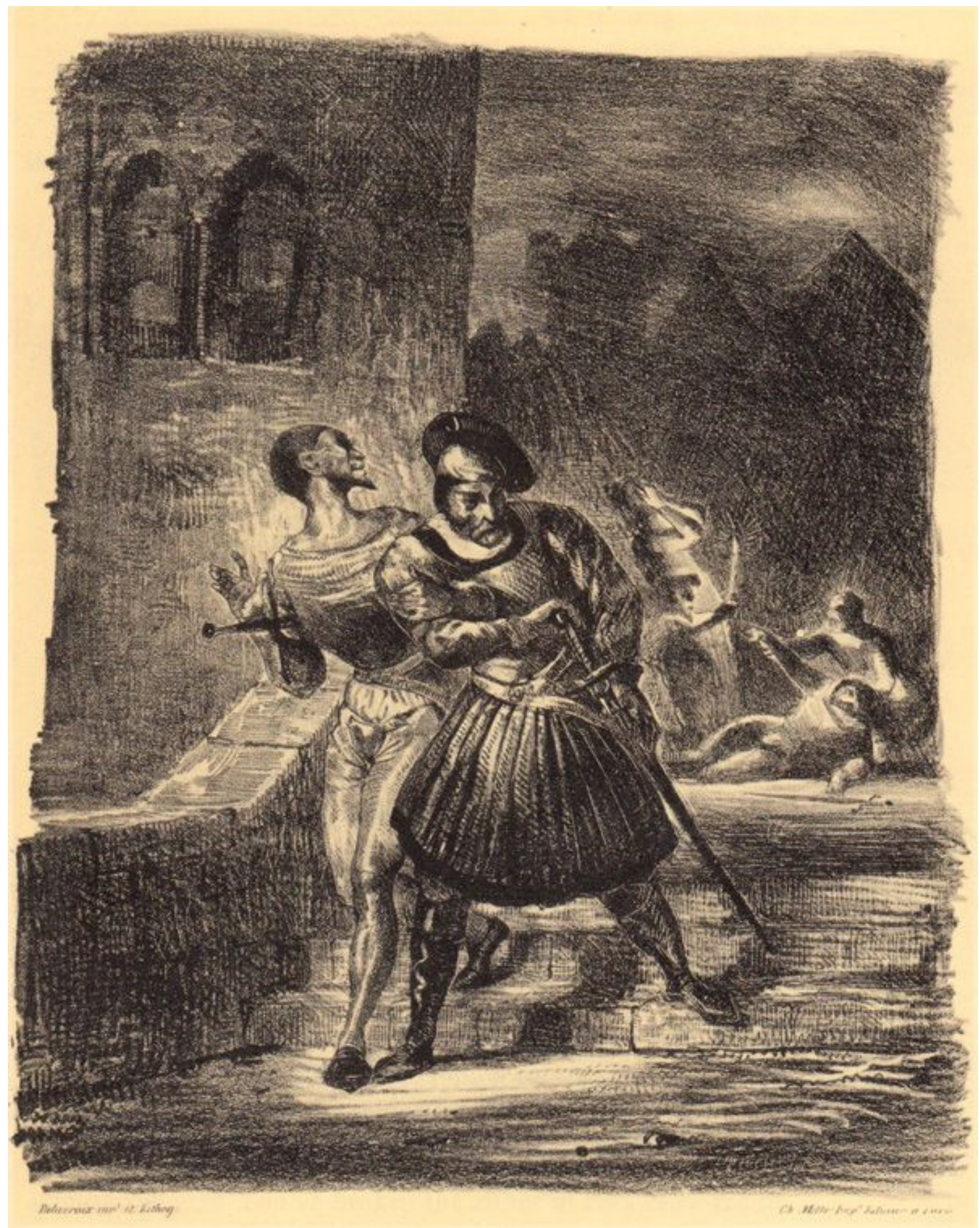

MEPHISTOPHELES: Quick, let's be off! It's time to disappear.

Fausto. Eugene Delacroix, 1828. Disponível em oldbookillustrations.com 


\subsection{Acumulação extensiva e urbanização}

As relações de produção capitalistas surgiram de maneiras muito variadas, mas sua origem, de modo geral, é baseada na desvinculação da subsistência como meio de reprodução da classe trabalhadora. Conforme visto, a generalização do mercado enquanto âmbito regulador da produção impõe, de maneira crescente, a transformação do produto social em valores de troca. Ou seja, o faz assumir a forma de mercadoria, em oposição à produção de valores de uso - sobre a qual repousa a subsistência. Com isso, o capitalismo, fundado no mecanismo do mercado, cresceu sobre a produção de valores de uso e, portanto, em detrimento do modo como se reproduziam os trabalhadores.

A contrapartida a passou a ser o salário. Trata-se de rendimento - não necessariamente monetizado -, que, no ato da produção, constitui a parcela do produto que os trabalhadores recebem em troca da disponibilização de sua força de trabalho, e pelo qual provêem seu sustento. Essa relação caracteriza-se como uma relação de mercado, pois se alicerça na troca, vale dizer, de trabalho por salário. Não à toa, modernamente se aplica o termo "mercado de trabalho".

Nesse "mercado", a produção se realiza em uma esfera descentralizada que depende, a princípio, unicamente das vontades das partes envolvidas: capitalistas e trabalhadores. Acontece sem a necessidade dos chamados mecanismos extraeconômicos, sem coerção, de forma "espontânea". Isso porque, sem os meios de sua reprodução, os trabalhadores não têm outra opção, a não ser vender sua força produtiva. Portanto, apesar das relações capitalistas não se consumarem de maneira compulsória, são inescapáveis para a existência dos trabalhadores. Resisti-las sempre foi uma luta perdida.

Mas essa transformação, como já esboçado, não foi pacífica, tampouco instantânea, nem sequer se completou no mundo atual. Visto que a subsistência normalmente está associada à terra, a supressão de seu elo com os trabalhadores é 
uma das condições históricas para a emergência das relações de produção capitalistas. Por isso, esse processo de formação da nova economia, em tese regida pelo mercado, corresponde ao êxodo rural e ao conseqüente crescimento das cidades.

Os trabalhadores, então proletários, afluem, prontos e prontamente, para o trabalho nas cidades, fazendo dessa relação, entre desenvolvimento capitalista e urbanização, algo inextrincável. Se lida assim, a evolução da urbanização, ou do percentual da população urbana contra o todo, marca também a evolução desse movimento inicial do capitalismo.

Não é rara a referência às cidades da Antiguidade, do Renascimento, ou da China Imperial como grandiosas conjunturas urbanas. Mas do ponto de vista econômico e populacional, essas realidades urbanas eram inexpressivas, abrigando pouco mais que um décimo da população dessas sociedades. Como exemplo, tomese, primeiro, o caso europeu. Em seu estudo sobre a urbanização da Europa entre os séculos XVI e XIX, Jan De Vries mostra que as nações européias se tornaram propriamente urbanas - isto é, com mais de $50 \%$ de sua população morando em cidades - somente depois ou durante o século $\mathrm{XIX}^{112}$. Ver tabela abaixo.

\begin{tabular}{|c|c|c|c|c|c|c|c|}
\hline \multicolumn{8}{|c|}{ PERCENTUAL DE POPULAÇÃO URBANA TOTAL, 1500-1800 } \\
\hline Região & 1500 & 1550 & 1600 & 1650 & 1700 & 1750 & 1800 \\
\hline Inglaterra e Gales & 3.1 & 3.8 & 5.8 & 8.8 & 13.3 & 16.7 & 20.3 \\
\hline Holanda & 15.8 & 15.3 & 24.3 & 33.1 & 33.6 & 30.5 & 28.8 \\
\hline Bélgica & 21.1 & 22.7 & 18.8 & 20.8 & 23.9 & 19.6 & 18.9 \\
\hline Alemanha & 3.2 & 3.8 & 4.1 & 4.4 & 4.8 & 5.6 & 5.5 \\
\hline França & 4.2 & 4.3 & 5.9 & 7.2 & 9.2 & 9.1 & 8.8 \\
\hline Itália & 12.4 & 12.8 & 14.7 & 14.0 & 13.4 & 14.2 & 14.4 \\
\hline
\end{tabular}

${ }^{112}$ DE VRIES, Jan. La urbanización de Europa - 1500-1800. Barcelona: Editorial Crítica, 1987. p. 66-67. 
Quanto aos países orientais, e, em especial à China, o volumoso compêndio de dados estatísticos históricos organizados por Angus Maddison apresenta números que não diferem, e, na verdade, estão bem aquém das taxas de urbanização da Europa Ocidental para o mesmo período ${ }^{113}$. Na China dessa época, segundo John Merrington, "os ares da cidade" - em referência à frase de Braudel -, não tinham o mesmo ímpeto transformador ${ }^{114}$. Veja-se os dados.

\begin{tabular}{cccc}
\hline \multicolumn{4}{l}{ TAXA DE URBANIZAÇÃO: JAPÃO, CHINA E OESTE EUROPEU, 1000-1890 } \\
\hline Ano & Japão & China & Oeste Europeu \\
\hline $\mathbf{1 0 0 0}$ & $n . a$ & 3.0 & 0.0 \\
\hline $\mathbf{1 5 0 0}$ & 2.9 & 3.8 & 6.1 \\
\hline $\mathbf{1 8 2 0}$ & 12.3 & 3.8 & 12.3 \\
\hline $\mathbf{1 8 9 0}$ & 16.0 & 4.4 & 31.0 \\
\hline & & Fonte: Adaptado de Maddison (2006).
\end{tabular}

De acordo com os dados do World Urbanization Prospects 2018 - projeto de estimativas e projeções populacionais do Departamento de Assuntos Econômicos e Sociais da ONU -, em 1950 somente a Europa, a América do Norte e a Oceania eram as regiões do mundo que alcançavam uma taxa de urbanização superior a $50 \%$. Em 2020, com exceção da África e da Ásia, todas as regiões do planeta apresentam um índice superior a 70\%; com destaque para as Américas, com mais de $80 \%$ de sua população vivendo em cidades $^{115}$.

Isso quer dizer que a urbanização não é uma tendência milenar da história. Explodiu, como se diz, nos últimos duzentos anos e, particularmente, na última metade do século XX. Ainda assim, atualmente, apenas 56\% da população mundial é urbana,

\footnotetext{
${ }^{113}$ MADDISON, Angus. The world economy: a millennial perspective. Vol. I. Paris: OECD Publishing, 2006. p. 42.

${ }^{114}$ MERRINGTON, John. A Cidade e o campo na transição para o capitalismo. In: SWEEZY, Paul et al. A transição do feudalismo para o capitalismo. Rio de Janeiro: Paz e terra, 1977. p. 179.

${ }^{115}$ ONU. World Urbanization Prospects 2018. Disponível em: https://population.un.org/wup/. Acesso em: $13 / 01 / 2020$.
} 
o que representa considerável espaço para a continuidade do processo que anima a urbanização. E esse processo, como argumentado, não pode ser outro que não a constituição das relações de produção capitalistas.

Para Csaba Deák, isso constitui, no desenvolvimento capitalista, um estágio extensivo de acumulação. É, em essência, a ampliação do mercado, como âmbito de regulação da produção, sobre as formas sociais previamente existentes. É levado a cabo pela expropriação campesina, resultando o assalariamento, a migração campocidade e a conseqüente urbanização ${ }^{116}$. Cabe observar que, sob esse conceito de acumulação extensiva, a interpretação de Deák estabelece explícita interlocução com os trabalhos de Michel Aglietta e, por meio desse, enseja um cotejamento a chamada abordagem regulacionista, assim como, aos autores que a orbitam, a exemplo de David Harvey e Giovanni Arrighi.

Adiante, esse cotejamento será apresentado em mais detalhes. Cumpre, por ora, explorar suas definições pela oportunidade que possibilitam no desenvolvimento da hipótese deste trabalho.

Na concepção de Michel Aglietta, a evolução capitalista envolve dois estágios: o estágio predominantemente extensivo e o estágio predominantemente intensivo de acumulação. No primeiro, há a transformação das condições em que se realiza 0 trabalho; ou seja, consiste na sua conversão em trabalho assalariado. As relações de produção capitalistas são estendidas sobre a antiga organização produtiva, de modo que o excedente capitalizado é alargado sob altas taxas mediante a incorporação da produção existente. No segundo, com as relações de produção transformadas, a acumulação só pode progredir com a modificação das condições de existência do trabalho assalariado - com sua reprodução ${ }^{117}$.

Tenha-se, preliminarmente, foco nesse primeiro estágio do capitalismo. Nele, a acumulação extensiva corresponde precisamente ao conteúdo da crise do feudalismo

\footnotetext{
${ }^{116}$ DEÁK, Csaba. Em busca das categorias de produção do espaço. São Paulo: Annablume, 2016. p. 117.

${ }^{117}$ AGLIETTA, Michel. Regulación y crisis do capitalismo. México: siglo XXI, 1976. p. 56-57.
} 
e da emergência das relações de produção capitalistas, conforme exposto por Deák e apresentado no capítulo anterior. Marca, segundo Aglietta, a destruição do "universo espaço-temporal" estabelecido pelas formas pré-capitalistas, caracterizado pela dualidade campo-cidade, pelo ritmo de trabalho ditado pela natureza e, sobretudo, pela intrínseca relação entre atividades produtivas e domésticas - pode ser dito, pautadas pela subsistência ${ }^{118}$.

Robert Boyer, eminente teórico regulacionista, identifica a origem do capitalismo com o que denomina um regime extensivo de acumulação. Nesse regime, a concorrência (o mercado) e a relação salarial se impõem à totalidade da atividade econômica. É o momento em que o proletariado industrial se encontra em pleno desenvolvimento, contribuindo decisivamente para a formação da indústria, ainda que participe muito pouco da demanda por sua produção ${ }^{119}$.

Em outros termos: na acumulação extensiva, a produção industrial é baseada na formação do operariado, mas não é voltada a sua reprodução. Além disso, continua Boyer, essa acumulação se estabiliza e prossegue, em face de suas debilidades, por meio da oscilação sobre a formação salarial - isto é, em detrimento dela. Com isso, nas palavras do autor, "as espetaculares e dolorosas transformações sociais asseguraram o florescimento do primeiro capitalismo industrial”120.

Em certo sentido, é plausível a idéia de que esse processo se tratou de uma distribuição de renda às avessas, em favor dos extratos burgueses. Karl Polanyi, descrevendo os cercamentos e suas decorrências, afirma que todas essas circunstâncias significaram, na verdade, uma "revolução dos ricos contra os pobres", cujos efeitos deletérios beiraram a catástrofe social ${ }^{121}$.

De modo a justificar e generalizar essa revolução através do tecido social, o capitalismo constituiu-se também, como qualquer outra sociedade, de formas

\footnotetext{
118 Ibidem. p. 58.

${ }^{119}$ BOYER, Robert. Teoria da regulação: os fundamentos. São Paulo: Estação Liberdade, 2009. p. 83-84.

${ }^{120}$ Ibidem.

${ }^{121}$ POLANYI, Karl. The Great Transformation. Boston: Beacon press, 2001. p. 38. 187-188.
} 
ideológicas. Para Deák, na emergência das relações de produção capitalistas, o liberalismo surgiu como a forma ideológica correspondente à acumulação extensiva. Apesar de suas muitas implicações, o liberalismo apresentava em sua essência a abolição da servidão e a instituição do trabalho assalariado como a base da idéia de liberdade. Essa idéia, uma vez identificada com o bem-comum, fundava o princípio organizador da nova sociedade e deveria, por isso, ser perseguida como tal, daí o termo liberalismo ${ }^{122}$.

Conceito de certo maneira equivalente à noção de formas ideológicas é o que a abordagem regulacionista chama de modos de regulação. Trata-se de um conjunto de procedimentos e comportamentos, individuais e coletivos, que visam a reproduzir as relações sociais fundamentais, a sustentar e dirigir o regime de acumulação e, finalmente, a garantir a compatibilidade das decisões descentralizadas de todos os atores econômicos ${ }^{123}$.

No caso da acumulação extensiva, o modo de regulação consonante é o que Boyer denomina "modo de regulação concorrencial". Em oposição ao keynesianismo que a, seu ver, caracteriza a regulação do regime intensivo e surge com a crise do extensivo -, o modo de regulação "concorrencial" a que Boyer se refere só pode ser o ideário e a conjuntura do liberalismo, apresentada e teorizada nas obras de autores clássicos como Adam Smith, James Steuart e John Locke ${ }^{124}$.

De acordo com John Merrington, as origens do capitalismo, como algo estabelecido em um processo que divorciava a produção e o consumo por meio do sistema de trocas, do assalariamento e da urbanização, já estavam formuladas com muita clareza nas obras clássicas do liberalismo do final do século XVIII, como as de Smith e Steuart ${ }^{125}$. Steuart, particularmente, examinou as conseqüências do que chamou de "separação entre a mãe terra e seus filhos laboriosos", "naturalmente"

\footnotetext{
122 DEÁK, Csaba. Op. Cit. p. 119-120.

${ }^{123}$ BOYER, Robert. A teoria da regulação: uma análise crítica. São Paulo: Nobel, 1990. p. 80.

${ }^{124}$ Idem. Op. Cit, 2009. p. 86,111.

${ }^{125}$ MERRINGTON, John. A Cidade e o campo na transição para o capitalismo. In: SWEEZY, Paul et al. A transição do feudalismo para o capitalismo. Rio de Janeiro: Paz e terra, 1977. p. 171.
} 
ocorrida com o desenvolvimento do mercado e da indústria. A sociedade, em sua opinião, só teria a ganhar com a transferência dos trabalhadores do campo - onde eram dispendiosos, pouco produtivos e passavam dificuldade - para a cidade, onde, supostamente, triplicariam seu consumo e seus rendimentos monetários retornariam à economia como capital a ser livremente investido ${ }^{126}$.

Adam Smith, por sua vez, também defendia algo parecido quando tratou da distinção entre trabalho produtivo e improdutivo. Produtivo era todo o trabalho que produzia mercadorias e cujo produto poderia ser reinvestido na produção. Já improdutivo era o trabalho que produzia valores de uso em si, como os serviços do Estado e o emprego de servos domésticos, focados, vale dizer, na reprodução de $\operatorname{algo}^{127}$.

Logo, expandir a produção de uma nação, para Smith, dependia de dois fatores. O primeiro era o crescimento da população de trabalhadores produtivos, envolvidos no processo de produção de mercadorias, equipados pelo capital e por ele comandados; portanto, cabe dizer, era o crescimento de assalariados. O segundo era o aumento da produtividade desses trabalhadores, que só poderia tomar efeito com a melhoria e manutenção desse mesmo capital $^{128}$. Isto é, apesar reconhecer a importância da produtividade, Smith não a associava à reprodução dos trabalhadores.

Além disso, essa transformação, apoiada na expropriação da subsistência da terra, também precisava apresentar um conceito de propriedade que dela desse conta. Essa construção era particularmente desafiadora, pois se erguia de um contexto ideológico em que a comunhão da terra era assegurada por instituições que já duravam séculos e era, ainda por cima, atestada nos textos bíblicos, fundamento moral e intelectual das discussões políticas à época. É nos trabalhos de Locke, talvez,

\footnotetext{
${ }^{126}$ STEUART, James. Inquiry into the principles of political economy. Vol. I, Cap. X. Disponível em: https://www.marxists.org/reference/subject/economics/steuart/index.htm. Acesso em: 16/01/2020. ${ }^{127}$ SMITH, Adam. The Wealth of nations. Livro II, cap. 3. Disponível em: https://www.marxists.org/reference/archive/smith-adam/works/wealth-of-nations/index.htm. Acesso em: $16 / 01 / 2020$.

${ }^{128}$ Ibidem.
} 
que a idéia de propriedade privada encontra sua primeira elaboração, com grande influência no pensamento liberal de autores posteriores, como Adam Smith.

Segundo Martin Seliger, Locke não negava a propriedade comum da terra, mas o direito de apropriá-la individualmente pelo trabalho constituía exemplo máximo de sua visão sobre os direitos individuais, consagrados pela lei natural. Em sua visão, a comunhão era o estado original da terra, pois dela se extraiam os frutos da natureza, que não derivavam do trabalho. Entretanto, uma vez cultivada, a terra, por justiça natural, passava a propriedade de quem a primeiro trabalhou ${ }^{129}$.

Acontece que os trabalhadores subseqüentes empregados pelo proprietário original não adquiriam o mesmo direito sobre essa terra. Mas, para Locke, isso não configurava uma incompatibilidade com aquela mesma lei natural, pois tais trabalhadores eram compensados por isso, com o salário. Dessa forma, Locke justificava tanto o trabalho assalariado como os cercamentos. Esses só não deveriam ocorrer se a terra não fosse cultivada; sendo-a, a propriedade comunal não se aplicava e se tornava propriedade privada ${ }^{130}$.

À primeira vista, toda essa retórica parece o mais puro cinismo e engodo, considerando o fosso de desigualdade socioeconômica que se aprofundava com o nascimento do capitalismo. Contudo, tais preceitos liberais não eram logicamente incongruentes com a nova realidade, sendo, na verdade, como observou Thomas Marshall, necessários a ela ${ }^{131}$.

Somados ou embasados na idéia de igualdade, os princípios de liberdade e propriedade constituíram o que Marshall chamou de "direitos civis". Marcaram o primeiro degrau da evolução histórica que o autor enxergava na construção da cidadania - seguidos pelos direitos políticos e pelos sociais. Ainda que interligados pela idéia de igualdade, os direitos civis não conflitavam com as desigualdades

\footnotetext{
${ }^{129}$ SELIGER, Martin. The liberal politics of John Locke. Nova York: Frederick A. Praeger, 1969. p. 18,200203.

${ }^{130}$ Ibidem.

${ }^{131}$ MARSHALL, Thomas. Citizenship and social class. In: MANZA, Jeff; SAUDER, Michael (Org.). Inequality and society. Nova York: W. W. Norton and Co., 2009. p. 148-150.
} 
estruturais da formação do capitalismo, pois eram, na verdade, essenciais a construção da sociedade de mercado e das instituições do trabalho assalariado. Permitiam que os indivíduos adentrassem o processo econômico como unidades independentes e sem a proteção social de que antes se serviam ${ }^{132}$ - portanto sem foco em sua reprodução.

Conceituados por juristas como "direitos negativos", que buscam conter a ação do Estado sobre os indivíduos, esses preceitos coadunavam-se aos objetivos históricos do liberalismo na remoção dos obstáculos impostos pela velha ordem social. Nesse estágio do desenvolvimento capitalista, segundo Deák, a forma-ideológica do liberalismo era suficiente em suas elaborações, que procuravam apenas instituir as novas relações de produção, tendo na idéia de auto-regulação sua expressão mais sofisticada, como a analogia da "mão invisível" proposta por Adam Smith ${ }^{133}$.

De acordo com Nikolai Karataev, o trabalho de Smith parte de seu conceito de "homem econômico", inteiramente baseado na primazia do interesse próprio na regulação social. Por meio do mercado e perseguindo seus interesses próprios, os indivíduos alcançariam seus objetivos, que não entrariam em choque com o interesse coletivo, pois estariam respeitando a ordem natural das coisas ${ }^{134}$. Com isso, o trabalho de Smith justificava e apoiava-se no conceito de laissez-faire da filosofia fisiocrata mínima intervenção -, sendo incorporado como um preceito, pela influência posterior de suas proposições, ao lado das de Jeremy Bentham, na prática política e na defesa do mercado auto-regulado na Inglaterra do século XIX.

É na superficialidade das relações capitalistas como sistema de mercado que, para Marx, reside o verdadeiro conteúdo ideológico dos pressupostos liberais. A relação salarial, ao postular a liberdade do trabalhador para trocar um valor legitimamente seu, o trabalho, por outro supostamente equivalente, o salário, dispõe

\footnotetext{
132 Ibidem.

133 DEÁK, Csaba. Op. Cit. p. 120.

${ }^{134}$ KARATAEV, Nikolai. et all. Historia de las doctrinas econômicas. México: Editorial Grijalbo, 1964. p. 158.
} 
trabalhadores e capitalistas em pé de igualdade, como proprietários que, de forma mútua e espontânea, por meio do sistema de mercado, satisfazem suas necessidades, seus interesses individuais. Assim, a aparência do trabalho assalariado condensaria os valores burgueses de liberdade, igualdade e propriedade, o "paraíso dos direitos inatos do homem", ironiza Marx ${ }^{135}$.

O que justificavam, portanto, era a ascensão de uma realidade econômica regulada, em tese, de maneira descentralizada, e que se realizou às custas do gigantesco contingente de trabalhadores incorporados ao sistema capitalista. Nesse sentido, Deák acrescenta que a acumulação extensiva é composta, a princípio, por dois elementos: o assalariamento e o progresso técnico, sendo o primeiro de grandeza muito superior ao segundo com muito pouca preocupação com a reprodução dos trabalhadores, a ponto mesmo de caracterizar esse desenvolvimento inicial do capitalismo como algo "galopante" e "selvagem"136.

Como ilustração, é possível descrever a produção na acumulação extensiva como uma função da população de trabalhadores e da produtividade do trabalho (do progresso técnico).

Nesse entendimento, o crescimento do excedente produzido tem influência do aumento produtividade sobre a expansão da produção e do crescimento populacional, do número de trabalhadores. Como o crescimento populacional se divide em dois componentes, o crescimento vegetativo e por migração, o peso do crescimento populacional no aumento da produção também se divide em dois: um componente relativo ao crescimento vegetativo, e outro à migração, em especial, à migração campo-cidade ou à urbanização.

É justamente o terceiro termo, a proporção em que se estendem as relações de produção capitalistas, a parcela responsável pela magnitude excepcional da taxa de excedente. Tal se deve ao fato de que a conjuntura capitalista, em seu estágio

\footnotetext{
${ }^{135}$ MARX, Karl. Op. Cit., 1990. p. 280.

${ }^{136}$ DEÁK, Csaba. Op. Cit. p. 118.
} 
extensivo, se vale da absorção de trabalhadores por ela não reproduzidos. No entendimento de Deák, o termo que representa a incorporação dos trabalhadores, o assalariamento, constitui, por isso, um "saque" contra as formas pré-capitalistas ${ }^{137}$.

No argumento deste trabalho, é essa a razão para o desencadeamento dos antagonismos entre mercado e Estado, como instâncias de regulação social. Em um primeiro momento, a não reprodução dos trabalhadores, ou falta de preocupação com essa questão, não é um problema para acumulação capitalista extensiva, que cresce generalizando a forma-mercadoria. Contudo, são as limitações da forma-mercadoria em encaminhar a reprodução dos trabalhadores o que faz o supracitado antagonismo um conteúdo intrínseco da evolução capitalista, que se explicita apenas em um estágio posterior à exaustão da acumulação extensiva e implica, desse modo, sua substituição por uma acumulação intensiva.

A própria lógica do desenvolvimento econômico se encarrega de ilustrar isso, como mostra Arthur Lewis, destacado economista da teoria do desenvolvimento. Para Lewis, uma economia em desenvolvimento - ou talvez pudesse ser dito, em seu estágio extensivo - é caracterizada pela oferta ilimitada de força de trabalho e sua produtividade em níveis próximos a zero. Tal ocorre, nesse momento da acumulação, por conta de um diminuto setor capitalista que se expande sobre uma imensa economia de subsistência ${ }^{138}$.

Seguindo a chamada regra das proporções variáveis, segundo a qual o capital deve ser empregado até a mínima produtividade marginal do trabalho para maximização do lucro, o emprego dos trabalhadores tomaria efeito mesmo com salários nulos. Como, na prática, nenhum salário pode ser nulo, o setor capitalista dessa economia se define com base em um nível de salário que é, por sua vez,

\footnotetext{
${ }^{137}$ DEÁK, Csaba. Op. Cit. 2016. p. 118.

138 LEWIS, Arthur. Economic Development with unlimited supplies of labour. Manchester School, Vol. 22-2, 139-190 . 1954. p. 145-146.
} 
lastreado no setor de subsistência, embora normalmente acima dele, tal qual exemplifica o esquema a seguir ${ }^{139}$.

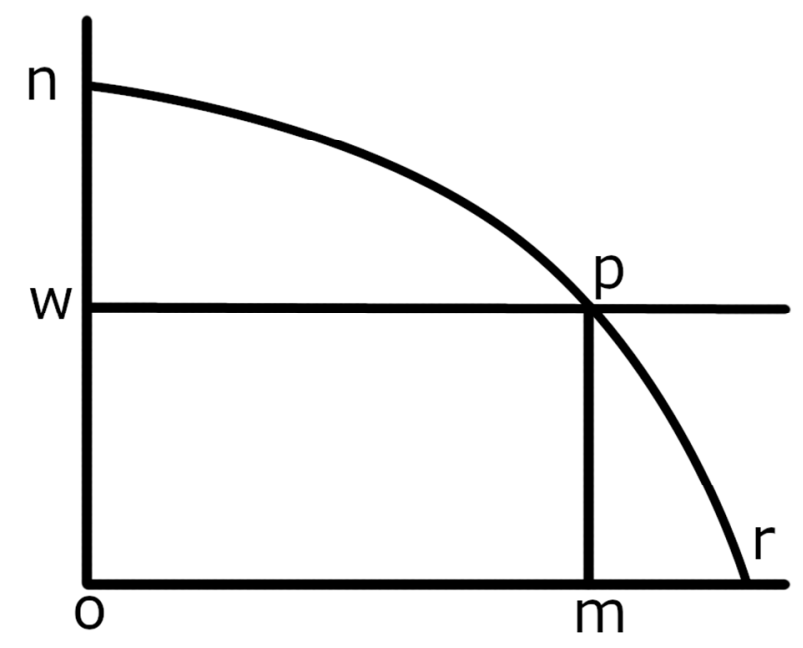

Fig. 1 - Oferta e produtividade de trabalho em uma economia em desenvolvimento. Adaptado de Lewis (1954).

No esquema acima, a quantidade de trabalho é medida no eixo horizontal e, no vertical, seu produto marginal (sua produtividade). O ponto w é o nível de salário no setor capitalista e a curva "nr" a função de produtividade do trabalho. De acordo com Lewis, se a produtividade for zero fora do setor capitalista, a quantidade "or" de trabalho deverá ser empregada, mas somente "om" o será no setor capitalista. Assim, a área definida pelos pontos $\mathrm{w}, \mathrm{p}$ e $\mathrm{n}$ representa $\mathrm{o}$ excedente capitalista; aquela definida por o,w,p e m, o total dos rendimentos dos trabalhadores no setor capitalista; e, além do ponto $\mathrm{m}$, o restante dos trabalhadores ganham o que podem no setor de subsistência, ou seja, não são reproduzidos pela economia que ajudam a sustentar.

Visivelmente, não se tratando de um dualismo entre setores capitalistas e de subsistência, essa economia se alimenta, por assim dizer, de todos os trabalhadores paulatinamente a ela adicionados. Fundando-se na idéia de Adam Smith sobre transferência de excedente do trabalho improdutivo ao produtivo, Lewis diferencia seu modelo do neoclásisco (de pleno-emprego), por incorporar a importância de outras ${ }^{139}$ Ibidem. 
fontes de influxo do trabalho na dinâmica capitalista, que não o simples crescimento vegetativo. Destaca, com isso, a relevância da migração, que faz com que determinadas regiões cresçam à míngua de outras, ao lado de todas as formas arcaicas da economia progressivamente envolvidas pelo capitalismo - como a agricultura camponesa e a produção doméstica (cottage industry) ${ }^{140}$.

Para Lewis, o excedente acumulado e reinvestido no setor capitalista aumenta a porção de capital fixo no processo produtivo e, dessa forma, a produtividade marginal do trabalho, incrementando a curva que insere mais trabalhadores ao setor capitalista $^{141}$. Eventualmente, a melhora da produtividade e a relativa escassez da força de trabalho, que se rarefaz de maneira sensível com o término das migrações, ou, equivalentemente, com virtual completa urbanização da população, reajustariam, pela simples lógica de mercado e a níveis bem mais altos, o preço do trabalho, ou seja, o salário. Isso, contudo, é o que esta tese refuta.

Nesta reflexão, a reprodução da força de trabalho no capitalismo não pode se realizar sob a forma do mercado, pois tanto seu preço - o salário -, quanto sua quantidade são definidos fora desse âmbito de regulação. Tampouco sua produtividade é uma variável que, por esse mesmo mecanismo, poderia manifestar qualquer tendência progressiva, visto que depende do nível de reprodução dos trabalhadores. E se essa reprodução estiver ancorada nos rendimentos que os trabalhadores recebem no mercado - no salário -, então, o modelo de acumulação entra em uma espécie de curto-circuito, erodindo a produtividade com a degradação das condições de reprodução da classe trabalhadora.

Para Deák, o preço de algo estabelecido pelo mercado, pelo jogo da oferta e da procura, nada mais é do que a oscilação sobre seu preço de produção. Esse preço é definido na esfera da produção, incluindo todos seus custos, o que abarca, aliás, o

\footnotetext{
${ }^{140}$ Idem. Unlimited labour: further notes. Manchester School, Vol. 26-1, 1-31 . 1958. p. 3.

${ }^{141}$ Idem, Op. Cit., 1954. p. 152.
} 
lucro. Portanto, o que o mercado regula efetivamente não é o preço de produção, e sim a quantidade de um bem ou serviço ofertado ${ }^{142}$.

No caso do trabalho, se a esfera em que se dá a formação de seu preço de produção for a subsistência, e tendo em conta sua contínua deterioração na acumulação extensiva, então, o trabalho é também continuamente depreciado. Além disso, como o preço, a quantidade de trabalho a ser empregada não é determinada pelo mercado. Pelo fato de que o assalariamento e a expropriação da subsistência não deixam alternativas - a não ser a venda obrigatória do trabalho -, a quantidade de trabalho é sempre ofertada de modo completamente elástico e involuntário. No capitalismo, aos desprovidos, o capricho da preguiça pode custar a vida.

Por fim, o mercado também é limitado na provisão da reprodução dos trabalhadores devido as suas reconhecidas falhas na produção de determinados valores, como as externalidades e a necessidade de universalização de bens e serviços específicos. São valores de uso cujo benefício alcança a todos independentemente de pagamento, indiferente à realização do ato de mercado, e que, por isso, precisam ser tarifados, literalmente: impostos, como segurança pública, iluminação pública, limpeza urbana... Há também o contrário, valores que precisam ser disponibilizados a todos e, portanto, a qualquer preço, de modo que dificilmente comportarão lucro, como saneamento, segurança alimentar, saúde, educação, transporte e habitação.

Sintomaticamente, são valores normalmente associados à chamada agenda urbana, pois, afinal, com a expropriação da subsistência da terra, seguido do assalariamento e da urbanização, o lócus da produção passa a ser as cidades. A reduzida preocupação com a reprodução da força de trabalho na acumulação extensiva - que prescinde da mesma, uma vez que os trabalhadores emergem prontos das antigas formas sociais - caracteriza, assim, as precárias e tão peculiares

${ }^{142}$ DEÁk, Csaba. Op. Cit. 2016. p. 103. 
condições do ambiente urbano, como verificado no início da industrialização na Europa dos séculos XVIII e XIX.

Como observa Deák, essa é a miserável realidade das aglomerações urbanas que constituíram o conteúdo do gênero literário de autores como Dickens e Vitor Hugo $^{143}$. É também a matéria do vívido e detalhado relato de Engels sobre as condições desse proletariado na Inglaterra.

Segundo as observações de Engels, feitas na década de 1840, a classe trabalhadora vivia em condições que a consumiam em doenças e em um alto índice de mortalidade. Suas acomodações superlotadas, mal dimensionadas e mal equipadas favoreciam a propagação dessas doenças, em especial, doenças pulmonares. Como viviam em subalimentação crônica, sérios problemas digestivos eram comuns e o raquitismo afetava o desenvolvimento da maioria das crianças. Seus salários eram insuficientes para gastos com cuidados médicos e seu único alívio social eram os bares, que acabavam intensificando o problema do alcoolismo ${ }^{144}$.

Como os pais precisavam trabalhar, o cuidado com as crianças muitas vezes era negligenciado, o que, freqüentemente, resultava as mais esdrúxulas e desnecessárias mortes por acidente. As escolas eram raras e de má qualidade, sendo o ensino obrigatório inexistente. A própria vida familiar era algo impossível para os trabalhadores, cujos lares transformaram-se em algo como albergues noturnos ${ }^{145}$.

No olhar de Braudel, as cidades cresciam, sobretudo, com o influxo dos miseráveis. Os trabalhos pesados eram deixados aos estrangeiros ou migrantes, em um processo o qual, guardando semelhanças com a escravidão, constituía, nas

\footnotetext{
${ }^{143}$ Ibidem. p. 118.

${ }^{144}$ ENGELS, Frederick. The condition of the working class in England. Results. Disponível em: https://www.marxists.org/archive/marx/works/1845/condition-working-class/index.htm. Acesso em: $16 / 01 / 2020$.

${ }^{145}$ Ibidem.
} 
palavras de Braudel, um "recrutamento forçado e ininterrupto", consumindo os trabalhadores na mesma velocidade com que precisava repô-los ${ }^{146}$.

Isso certamente deixava os trabalhadores em débeis condições de reprodução. Com dados relacionados a Paris do final do século XVIII, Braudel conta como 1/5 dos trabalhadores morria anualmente, em hospitais com não mais de 1.200 leitos para 5.000 ou 6.000 doentes. A cada 30.000 nascimentos, havia 7.000 ou 8.000 mil crianças abandonadas pelos pais, cuja prática de depositá-las em hospitais deu origem à peculiar profissão de "carregador de crianças". Tratava-se de uma espécie de "carrocinha", que coletava crianças pequenas em caixas almofadadas que podiam conter a três bebês, deitados, agachados ou em pé; assim, com a caixa tampada, as crianças eram transportadas aos hospitais, em uma viagem que, não raro, as matava $^{147}$.

Aparte a morbidade e perversidade, esses pormenores ilustram a completa indiferença com a reprodução dos trabalhadores nas cidades, que cresciam desordenadamente, seguindo seu impróprio princípio de constituição medieval. Muralhas eram feitas e refeitas para acomodar seu crescimento imprevisto, de maneira improvisada, com ruas tortuosas e plantas complicadas e ineficientes ${ }^{148}$.

Tal situação se arrastou até virada do século XIX, momento em que, para Antony Sutcliffe, as cidades européias assumiam as feições do caos. Os sistemas de drenagem e abastecimento não suportavam sua demanda, a poluição havia atingido níveis intoleráveis, as habitações populares estavam lotadas, as ruas congestionadas e a estrutura viária tornou-se um obstáculo à circulação e ao novo padrão de assentamento. Além de impor péssimas condições de vida a seus habitantes, tal situação constituía um verdadeiro embargo à capacidade produtiva das cidades. ${ }^{149}$.

\footnotetext{
${ }^{146}$ BRAUDEL, Fernand. Civilização material, economia e capitalismo: séculos XV-XVIII. V. I, as estruturas do cotidiano. São Paulo: Martins Fontes, 2009. p. 449.

147 Ibidem. p. 450.

148 Ibidem. p. 454.

${ }^{149}$ SUTCLIFFE, Antony. Towards the planned city. Nova York: St. Martin, 1981. p. 5.
} 
O fato é que, com o arrefecimento do influxo de trabalhadores, a acumulação capitalista perdia o elemento motor que a permitia crescer mesmo em detrimento da reprodução da força de trabalho. Com seu esgotamento, que coincide com a evolução da urbanização, restava-lhe apenas a produtividade como ingrediente para sustentá-la na qualidade de reprodução social ampliada. Considerando, no entanto, que a produtividade depende do aparelhamento dos trabalhadores por meio da elevação do nível de suas condições de reprodução, e tendo em vista a estrutural incapacidade do mercado em prover tal elevação, a dinâmica capitalista precisou lançar mão de um outro expediente: o Estado. Entra em ação, desse modo, uma espécie de demônio servil, que vem em socorro da manutenção da ordem social pautada pelo mercado, mas que, dialeticamente, a corrói. 


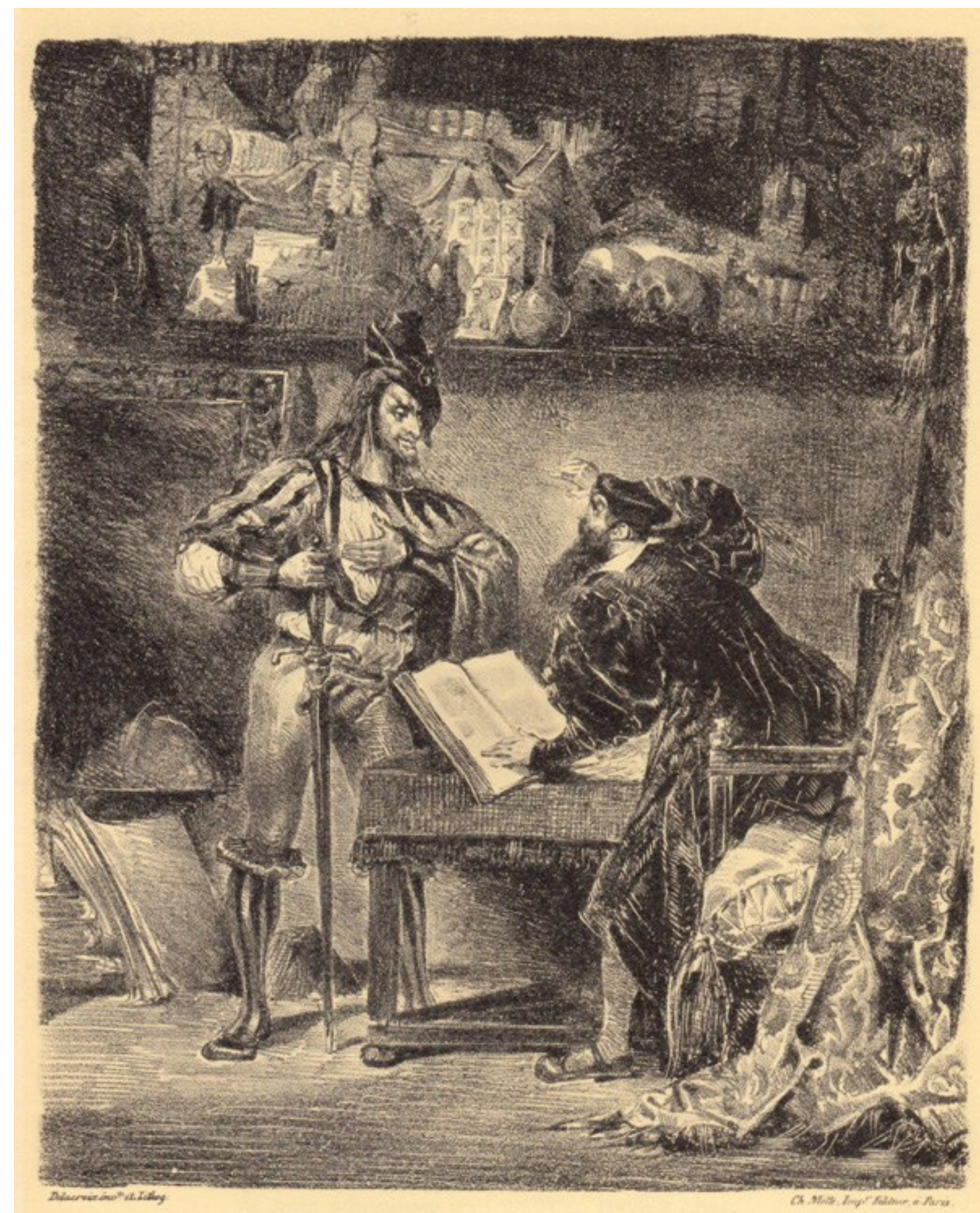

MEPHISTOPHELES: Why all this noise, sir? What can I do for you?

Fausto. Eugene Delacroix, 1828. Disponível em oldbookillustrations.com 


\subsection{Acumulação intensiva e planejamento}

A gradual exaustão do estágio extensivo da acumulação capitalista implica uma grande transformação. No caso dos países de capitalismo avançado, isso significou enormes crises sociais e reviravoltas políticas que, no fim, resultaram a conjuntura do chamado Estado de Bem-Estar. O que se argumenta é que esse Estado ascende, principalmente, pela imperiosa necessidade da reprodução da força de trabalho, que não podia mais ser incrementada às custas de formas sociais pretéritas.

Nesse contexto, a reprodução dos trabalhadores precisava ser viabilizada e intensificada, pois era a base da expansão da produtividade - principal, se não único elemento, então disponível, para geração de excedente e para continuidade da reprodução ampliada capitalista. Sem a possibilidade de que isso ocorresse espontaneamente pela regulação do mercado, foi preciso, portanto, que essa base fosse provida por um segundo âmbito de organização produtiva, o Estado, fundando, dessa maneira, os traços dialéticos da evolução capitalista.

Para Csaba Deák, a dialética do mercado e do Estado é uma decorrência do processo de generalização da forma-mercadoria, princípio motor do desenvolvimento capitalista. A produção de mercadorias é a tendência que constitui o capitalismo, mas seu avanço encontra limites, pois nem tudo pode ser produzido como mercadoria. Parte crescente da produção, socialmente necessária, será realizada pelo Estado na forma de valores de uso enquanto tais, na forma de infraestruturas, cujo único objetivo é garantir a perpetuação daquela tendência - isto é, a primazia do mercado ${ }^{150}$.

Ainda que a atuação do Estado restrinja-se ao mínimo necessário para assegurar o primado da mercadoria, a produção de valores de uso constitui um cerceamento da produção dessas. É a própria produção de mercadorias que, ao esbarrar em seus limites, suscita sua contra-tendência. Assim, o Estado, mesmo que

\footnotetext{
${ }^{150}$ DEÁK, Csaba. Em busca das categorias de produção do espaço. São Paulo: Annablume, 2016. p. 100106.
} 
destinado a sustentar o mercado, é, nas palavras de Deák, "irremediavelmente antagônico" ao mesmo ${ }^{151}$, instituindo, vale dizer, um movimento que não pode ser caracterizado como pendular e que se intensifica com o prosseguimento da acumulação ${ }^{152}$.

Isso, contudo, não marca o advento do Estado capitalista. No capitalismo, o Estado é uma força congênita. Além disso, não torna o mercado mais eficiente, e sim torna sua existência possível ${ }^{153}$.

Conforme Deák, seus principais campos de intervenção são (1) a manutenção de instituições - como a propriedade -, que implicam (2) a produção e propagação da ideologia, e (3) o monopólio da violência. Pode-se pensar também (4) no suporte a indústrias obsoletas que ainda são necessárias e a ramos essenciais da atividade econômica, como o chamado departamento I. Além disso, é claro, há (5) as infraestruturas necessárias à organização da produção e à estruturação do espaço, assim como, à elevação do nível de reprodução da força de trabalho ${ }^{154}$. Todas essas são ações que nascem com o capitalismo e que fazem do Estado uma esfera indispensável a sua existência.

O que esta tese propõe é que a necessidade da reprodução da força de trabalho é o principal elemento, dos cinco apresentados acima, que impõe uma demanda propulsora e crescente no sentido da expansão do Estado e, assim, em sua dialética com o mercado. Essa necessidade, como observou Nuno Fonseca, contém um movimento ${ }^{155}$. É sua intrínseca vinculação com o aumento da produtividade o que constitui o imperativo da acumulação capitalista em seu acionamento incremental do Estado.

\footnotetext{
151 Ibidem.

152 Idem. O mercado e o Estado na organização espacial da produção capitalista. Espaço \& Debates. 28:18-31. São Paulo: Neru, 1989. p. 25-26.

${ }^{153}$ Idem. Rent theory and the pirce of urban land: spatial organization in a capitalist economy. Tese de Doutoramento, Universidade de Cambridge. 1985. p. 118.

154 Idem. Mercado e Estado (Verbete). Disponível em:

http://www.fau.usp.br/docentes/depprojeto/c_deak/CD/4verb/estadoem/index.html. Acesso em: 18/01/2020.

${ }^{155}$ FONSECA, Nuno. Notas de aula - AUP 5823 - Crítica à teoria da renda. FAU-USP. São Paulo, 2019.
} 
Como esboçado anteriormente, o crescimento da produção depende de três fatores: do crescimento da população de trabalhadores que, então, se subdivide em dois componentes, o crescimento vegetativo - ou natural - e por migração, e, finalmente, do aumento da produtividade.

De acordo com a chamada teoria da transição demográfica, ou modelo de Warren Thompson, o crescimento populacional natural ocorre pela diferença entre as taxas de natalidade e de mortalidade. Como ilustrado na figura abaixo, em um primeiro momento, tanto a natalidade como a mortalidade são altas, resultando um baixo crescimento da população.

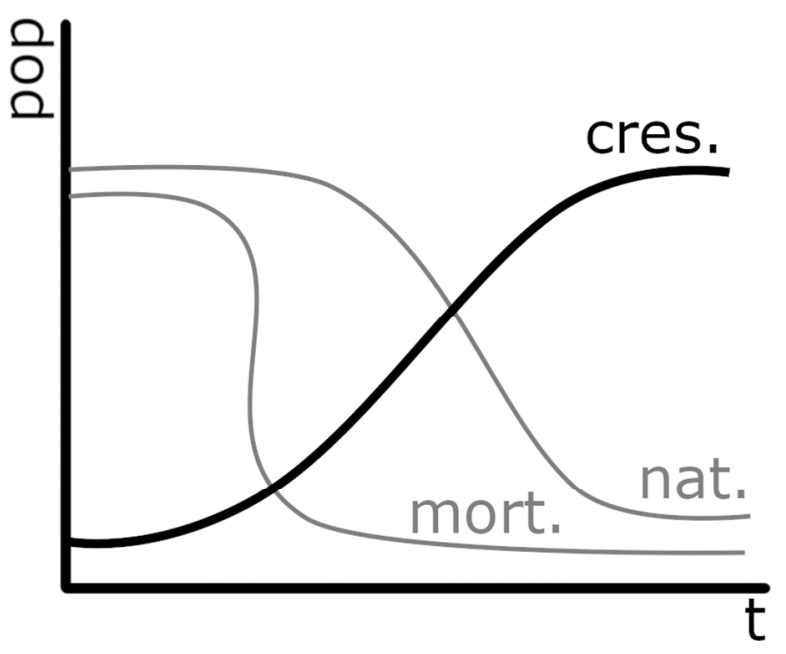

Fig. 4 - Ilustração do modelo de crescimento populacional.

Com a melhoria das condições de vida, a taxa de mortalidade apresenta uma queda maior que a natalidade, a qual, em momentos seqüentes, também começa a decrescer. Essas melhorias incluem, fundamentalmente, saneamento, saúde, regulação do trabalho, melhoria no suprimento alimentar e, enfim, todo o escopo da reprodução da força de trabalho. Assim, nessas etapas, o crescimento populacional tem sua maior variação e, então, tende a desacelerar. 
Ambas as taxas caem até que se estabilizam em patamares bem menores, estabilizando também o crescimento. Considerando a tendência da redução da natalidade e o limite inferior da mortalidade, o modelo de crescimento populacional sugere, no longo prazo, a redução natural da população, a menos que seja possível uma nova expansão da taxa de natalidade.

Cabe observar que, tanto a elevação da natalidade nesse último caso, quanto a diminuição da mortalidade, estão essencialmente relacionadas à melhoria das condições de reprodução da força de trabalho. Como também, aliás, está o aumento da produtividade, terceiro termo desse entendimento sobre o crescimento do excedente produtivo.. Ao passo que os dois primeiros, relativos ao crescimento populacional, estabelecem um limite para a variação máxima do excedente inicial, pois se esgotam ou se estabilizam em níveis mais baixos ou negativos - como ilustra a figura 2 -, somente a produtividade pode sustentar o excedente produtivo no longo prazo.

Essa situação implica a intensificação das forças produtivas por meio, sobretudo, do aparelhamento da força de trabalho. Uma vez que tal tarefa é deficitariamente realizada pelo mecanismo do mercado, a ampliação do âmbito de regulação do Estado sobre o conjunto da produção é inevitável, o que dá origem ao estágio intensivo de acumulação e exacerba sua dialética com o mercado ${ }^{156}$.

Nesse sentido, apesar das muitas sofisticações da economia política, a idéia de intensificar a produção não poderia ter outro significado que não uma operação sobre o trivial cotidiano da vida dos trabalhadores. "Intensivo", a propósito, foi a expressão que Michel Aglietta usou para qualificar a acumulação capitalista que emergia com a "modificação das condições de existência do trabalho assalariado" ${ }^{157}$ - com ênfase em sua reprodução.

\footnotetext{
${ }^{156}$ DEÁK, Csaba. Op. Cit., 2016. p.

${ }^{157}$ AGLIETTA, Michel. Regulación y crisis do capitalismo. México: siglo XXI, 1976. p. 56-57.
} 
De acordo com Robert Boyer, a teoria da regulação postula como intensivo o regime capitalista que, historicamente, surgiu nos países centrais no início do século $\mathrm{XX}$ e se estendeu até as primeiras décadas do pós-guerra. Também chamado de regime fordista ou fordismo, esse estágio da acumulação é marcado pela expansão da produtividade, pelo foco no consumo de massa e pela significativa redistribuição de renda, tudo isso baseado em uma nova relação do Estado com a economia, que se justificava no arcabouço teórico do keynesianismo ${ }^{158}$.

Essa nova relação do Estado, porém, não encontrava fundamento teórico apenas nos trabalhos de Keynes. Tinha, na verdade, um processo de constituição muito mais extenso e enterrava raízes no século XIX. O ideário do Estado de BemEstar é, no fundo, o ponto em que se encontrou a evolução, não muito consciente, tampouco reconhecida, do liberalismo reformista e do revisionismo social-democrata.

$\mathrm{Na}$ Inglaterra do final do século XIX, dentro do próprio partido liberal de William Gladstone, despontavam discursos de políticos que passaram a ser conhecidos como "novos liberais". Gladstone foi primeiro-ministro em uma época que o Governo Britânico reafirmou o liberalismo clássico, advogando a baixa intervenção e o rígido controle orçamentário. Essa persistência do laissez-faire ficou conhecida como "liberalismo gladstoniano", mas encontrou oposição mesmo dentro do partido que a praticava.

Conforme Robert Haggard, o "novo liberalismo" tinha uma pauta variada e seus principais representantes no Parlamento foram Richard Haldane, John Hobson e Leonard Hobhouse. Não obstante a sua carreira política, seus trabalhos teóricos tiveram grande influência internacional na crítica e na reforma liberal. Defendiam o combate à desigualdade social, a redução da pobreza e o fortalecimento da ação estatal contra crises cíclicas e o desemprego em massa. Apesar de classificados como "radicais", em momento algum deixaram de ser liberais, muito menos se posicionaram

${ }^{158}$ BOYER, Robert. Teoria da regulação: os fundamentos. São Paulo: Estação Liberdade, 2009. p. 84-86. 
como proponentes de uma revolução contra o capitalismo, que apenas tentavam reformar $^{159}$. Como síntese de seu pensamento, cabe a citação de Haldane:

"A simples remoção dos obstáculos que costumavam bloquear o caminho do progresso humano neste País já foi muita bem concluída. Estamos face a face com um novo tipo de problema social. O liberalismo passou de destrutivo a construtivo neste novo estágio da história."160

As proposições teóricas de John Stuart Mill também representam bem essa flexão do liberalismo. Para Eric Roll, nenhum outro filósofo foi tão bem preparado para continuar a tradição do liberalismo quanto John Mill. Filho de James Mill - notável filósofo liberal - e educado por Jeremy Bentham, John condensou em seus trabalhos, de um lado, os avanços da economia política até Ricardo e, de outro, estabeleceu uma visão crítica e reformista ao liberalismo ${ }^{161}$.

Influenciado pela filosofia de Augusto Comte e o chamado "socialismo fabiano", Mill opôs-se veementemente contra o laissez-faire e colocou em dúvida a regulação social pelo princípio do livre jogo dos interesses individuais, como proposto por Bentham. Foi um defensor - e, para Roll, o símbolo - da reforma social na Inglaterra fin de siècle, com a qual pretendia eliminar os males do capitalismo, sem destruir suas bases $^{162}$.

O positivismo de Comte e o socialismo fabiano foram os fundamentos do liberalismo reformista. Em grande medida traduziam a percepção da flagrante insuficiência dos pressupostos liberais clássicos na regulação da crise capitalista,

\footnotetext{
${ }^{159}$ HAGGARD, Robert. The persistence of victorian liberalism: the politics of social reformo $\mathrm{f}$ Britain 1870-1900. Londres: Greenwood Press, 2001. p. 125-126.

${ }^{160}$ HALDANE, Richard. The liberal creed. 1888. Apud: HAGGARD, Robert.. Op. Cit., 2001. p. 125.

${ }^{161}$ ROLL, Eric. A history of economic thought. Londres: Faber and Faber, 1961. p. 353-361.

162 Ibidem.
} 
muito centrada na questão dos trabalhadores. Ao mesmo tempo, apresentavam uma proposta titubeante para encaminhá-la.

Em seu livro "Uma visão geral do positivismo", Comte dedicou um extenso capítulo todo à questão da classe trabalhadora e à intervenção do Estado. Nele, advogou o controle da propriedade privada para realização de sua "natureza social". Imaginava que a ação estatal deveria ser orientada ao bem comum e, especificamente, ao bem-estar da classe trabalhadora. Sua visão, contudo, restringia o que definia como socialismo ao campo da reforma, negando o método e o propósito do comunismo no alcance da justiça e eficiência social ${ }^{163}$.

O socialismo fabiano, por sua vez, era um conjunto de concepções políticas propagadas por uma das primeiras organizações da sociedade civil, a Sociedade Fabiana. Fundada na Inglaterra em 1884 por membros da burguesia, tinha como princípio a reforma social em contraposição enfática à revolução. O conceito de seu nome retratava sua hesitante e cuidadosa estratégia política. Homenageava o general romano Fábio Máximo, que em guerra contra os cartagineses manteve uma postura de não ataque e de movimentos vagarosos que o levaram à vitória. Em sua analogia, os fabianos adotavam ação semelhante, defendiam uma lenta e imperceptível transição ao socialismo, mesmo que isso significasse "postergar". O dramaturgo Bernard Shaw foi um dos seus principais divulgadores.

Toda essa conjuntura da reforma social do liberalismo ainda sofria influência das idéias anteriores do chamado socialismo utópico. Diferentemente do liberalismo, como pontua Nikolai Karataev, o socialismo utópico não acreditava nas bases do capitalismo como suficientes para promover a equidade social e, por isso, propunha sua dissolução. Porém, seus principais pensadores, Claude Saint-Simon, Charles Fourier e Robert Owen, eram completamente avessos à idéia de revolução ${ }^{164}$.

\footnotetext{
${ }^{163}$ COMTE. Augusto. A general view of positivism. Cap. III. 1848. Disponível em: https://archive.org/details/ageneralviewpos00comtgoog/page/n4. Acesso em: 21/01/2020.

164 KARATAEV et al. História de las doctrinas econonomicas. v. I. México: Grijalbo, 1964. p. 247-249.
} 
De origem aristocrática ou burguesa, esses pensadores do início do século XIX dedicaram sua obra inteiramente à questão dos trabalhadores, mas, freqüentemente a confundiam com os interesses burgueses. Seus trabalhos eram também extremamente detalhistas em suas propostas, a ponto de especificar a estrutura espacial da reforma que imaginavam.

São exemplos as falanges e os falanstérios de Fourier. As primeiras eram unidades produtivas descentralizadas territorialmente e que centralizavam a população em um único edifício funcional e que congregava todas as classes sociais, os falanstérios $^{165}$. Suas idéias foram postas em prática em algumas situações e sobreviveram na arquitetura modernista, como nos trabalhos de Le Corbusier.

Apesar da denominação, "utópico" - que, nesse caso, tem acepção negativa -, suas proposições tiveram efeitos muito palpáveis. O industrial Robert Owen idealizou e teve papel preponderante no melhoramento das condições de trabalho, no estabelecimento das primeiras cooperativas industriais e na criação de um sindicato central dos trabalhadores na Inglaterra. Em seus cálculos e estudos seguindo o método de David Ricardo, chegou à conclusão de que a rentabilidade de seus negócios dependia de um grau muito elevado da exploração dos rendimentos dos trabalhadores, o que o levou a registrar sua surpresa e constrangimento: "Os operários são meus escravos!"166.

A continuação das teses de David Ricardo fez Owen e seus seguidores serem classificados como "socialistas ricardianos". Apesar de sua abordagem teórica incipiente e sua crítica social ingênua, os socialistas utópicos embasaram muito das elaborações marxistas, que passaram, então, a buscar um tratamento científico à questão e a interpretar o capitalismo como um sistema social, em si, incapaz de dirigir suas próprias crises e falhas ${ }^{167}$.

\footnotetext{
165 Ibidem. p. 254-261.

${ }^{166}$ Ibidem. p. 261-271.

167 Ibidem. p 271.
} 
Simultaneamente, na segunda metade do século XIX, no contexto da II Internacional, marxistas como Eduard Bernstein, Rudolf Hilferding e Karl Kautsky apresentaram as teses revisionistas do marxismo e que se consagrariam como o arcabouço teórico da Social-Democracia. Tratava-se das teses do "capitalismo organizado", formalizadas, principalmente, por Hilferding - um dos mentores intelectuais por trás da República de Weimar. Em essência, o "capitalismo organizado" pressupunha que, por meio da intervenção estatal e do planejamento, seria possível amenizar as crises do capitalismo, melhorar as condições de reprodução da força de trabalho e diminuir o desemprego, conferindo ao desenvolvimento capitalista, de tal modo, características socialistas ${ }^{168}$.

Antes de os partidos sociais-democratas aplicarem seu programa de reformas - que, em grande medida, se materializou na República de Weimar como uma solução no entre guerras, como nota Eberhard Kolb ${ }^{169}$ - a Alemanha de Bismarck o empreendeu como uma necessidade de seu desenvolvimento capitalista. Com um processo de assalariamento e de urbanização que acelerou rapidamente desde a Unificação, a Alemanha chegou ao final do século XIX com as mesmas dificuldades econômicas enfrentadas pela Inglaterra, além de uma forte pressão da classe trabalhadora e dos partidos sociais-democratas. Essas urgências fizeram com que o Reich adotasse e colocasse em prática o mínimo da pauta social-democrata, sem contudo, afetar as estruturas básicas de seu capitalismo.

A possibilidade dessa manobra, executada por um governo dirigido por uma aristocracia agrária - os junkers -, foi vista pelos liberais ingleses como algo seguro e necessário à ordem econômica, tendo influenciado as discussões do "novo liberalismo". Porém, foi somente com Kautsky e Hilferding que essa política ganhou substância teórica, nas teses do capitalismo organizado.

\footnotetext{
${ }^{168}$ KARATAEV et al. História de las doctrinas econonomicas. v. I. México: Grijalbo, 1964. p. 620-644.

${ }^{169}$ KOLB, Eberhard. The Weimar Republic. Londres: Routledge, 1990. p. 3-4.
} 
Paralelo interessante ao capitalismo organizado são as idéias de John Maynard Keynes, maior expoente do pensamento econômico durante o século XX. Para Keynes, com o fim do laissez-faire e por meio do planejamento - o que representava "uma comunidade racionalmente dirigida" em suas palavras - seria possível eliminar paulatinamente as "características repreensivas do capitalismo"170.

De todos os teóricos apresentados até então, Keynes foi talvez o que menos se preocupou com a questão do trabalho e com aspectos cotidianos da economia. Em resumo, sua teoria procurava mostrar a falha das decisões descentralizadas do mercado em estabelecer um nível de equilíbrio na economia que levasse ao pleno emprego dos fatores de produção, em especial, do trabalho. Pela interdependência e sobredeterminação das variáveis agregadas do consumo, do investimento e da produção, o mercado faria sempre oscilar o nível final de produto em torno do plenoemprego. Isso porque a variável controlada, no caso, pelos empresários - o investimento -, era baseada em expectativas sobre a demanda e a taxa de lucro, que simplesmente desconheciam - nem poderiam conhecer de ante-mão.

Em tempos de insegurança, o investimento se retraía. O contrário levava ao crescimento elevado de estoques, que fazia o investimento retrair outra vez. Dessa forma, a impossibilidade de manter a economia continuamente em pleno-emprego, e, portanto, continuamente em sua capacidade máxima, era inevitável pela lógica do mercado. Mas essa teoria também abria espaço para a idéia de que por meio da intervenção estatal, com políticas fiscais e monetárias adequadas, era possível sustentar o nível de investimento e consumo e, assim, otimizar a economia.

Com isso, Keynes teorizou um poderoso artifício de controle da coletividade sobre si mesma e influenciou, por isso, praticamente todos os debates políticos do século XX, desde sua publicação. Curiosamente, é justamente sobre os pressupostos de Keynes que se estruturam as políticas contrasionistas do arcabouço neoclássico, pois, acima do pleno-emprego, justificam-se por combaterem a inflação - a chamada

\footnotetext{
${ }^{170}$ KEYNES, John Maynard. A teoria geral do emprego, do juro e da moeda. São Paulo: Nova Cultural, 1985. p. 154.
} 
inflação de demanda. De todo modo, o keynesianismo foi, mais do que tudo, um aporte aos argumentos do ideário da Social-Democracia, ou do Estado de Bem-Estar, que então emergia.

Quando não evocada diretamente, a teoria de Keynes caia como luva nas ações governamentais que procuravam dar conta da crise do estágio extensivo capitalista. O melhor exemplo é provavelmente o "New Deal", Nos Estados Unidos pós-crise de 1929. De acordo com Roll, apesar de o New Deal ter evoluído em bases praticamente ad hoc, havia uma grande coincidência entre a política que perseguia e 0 trabalho de Keynes ${ }^{171}$.

A princípio, o escopo do New Deal ia além das medidas de Keynes. Tratava do aparelhamento da força de trabalho com a construção de uma série de equipamentos públicos direcionados à saúde, à educação, ao transporte, ao saneamento e ao lazer. Mas a "sopa de letras de Roosevelt" também guardava correspondência com o keynesianismo, ainda que essa correspondência se esclarecesse posteriormente.

Afinal, não era a WPA (Works Progress Administration) - agência que empregou milhares de desempregados em trabalhos operários públicos - ou a TVA (Tennessee Valley Authority) - programa de investimentos públicos no vale do Rio Tennessee, como hidroelétricas, obras de navegação e estradas - formas de ajuste do consumo e do investimento promovidas pelo Estado? Não teriam sido as tantas siglas que caracterizaram seu sistema de seguridade social e seguro desemprego - SSA, CWA, FERA... - uma das primeiras experiências na criação dos chamados "estabilizadores automáticos da economia"?

$\mathrm{Na}$ verdade, essa correspondência pouco importa, pois o que tal conjuntura mostrava era o quanto as ações políticas refletiam o desenvolvimento material da sociedade capitalista, e não seu contrário. Independiam de partidos ou visões políticas, tampouco se realizavam como projetos ou críticas de intelectuais isolados. Era a

${ }^{171}$ ROLL, Eric. Op. Cit., 1965. p. 502-503. 
verdadeira constituição de uma forma ideológica que respondia à evolução da economia.

A formação dessas novas proposições ideológicas era um movimento generalizado e permeava os mais diversos âmbitos da sociedade, como a academia e até a Igreja. São exemplos disso o positivismo, corrente de grande influência no meio acadêmico em fins do século XIX, e a doutrina social da Igreja Católica, que teve início com a encíclica Rerum novarum, em 1891, e culminaria no Concílio Vaticano II, 70 anos depois. Além de se manifestarem favoravelmente à intervenção estatal, tais concepções traziam à ordem política da época questões de cunho reformista. Além disso, sua abordagem metódica teve grande impacto na evolução das técnicas de planejamento e análise regional.

Assim, a combinação das propostas sociais-democratas, do keynesianismo e do reformismo social deu origem à chamada ideologia do Estado de Bem-Estar, hegemônica a partir de 1945. Como assinala Enrique Serra Padrós, a abandono das teses revolucionárias pela Social-Democracia e o fim do laissez-faire permitiram o consenso político de que resultou o Estado de Bem-Estar. Com isso, o Estado, por meio da encampação de atividades produtivas, de programas sociais e do planejamento, passou a ser o principal garantidor da estabilidade e do crescimento econômico, do pleno-emprego e da prosperidade social ${ }^{172}$.

Para Csaba Deák, o Estado de Bem-Estar e sua forma política mais explícita, a Social-Democracia, refletiam a nova base material do capitalismo: o estágio intensivo de acumulação. O aumento de produtividade do trabalho, garantido por meio do progresso técnico, resultou uma sensível elevação das condições de reprodução da força de trabalho. Mais saúde, educação, lazer e melhor ambiente urbano são

\footnotetext{
${ }^{172}$ PADRÓS, Enrique Serra. Capitalismo, prosperidade e Estado de Bem-Estar social. In: AARÃO REIS FILHOI (Org.). O século XX: tempo das crises. Rio de Janeiro: Civilização Brasileira, 2003. p. 248-251.
} 
necessários para sustentar o crescimento e a sofisticação dos processos produtivos, com maior variedade de serviços em um dia de trabalho mais curto ${ }^{173}$.

É nas transformações do ambiente urbano que essas modificações se pronunciam com grande clareza desde o final do século XIX. De acordo com Leonardo Benevolo, o período foi representado pelo modelo da cidade pós-liberal, em que o princípio da não-intervenção deu lugar à atuação estatal na reestruturação urbana ${ }^{174}$.

Como observou Anthony Sutcliffe, o modelo liberal anterior foi incapaz de encaminhar a precariedade que emergia nas cidades no início do capitalismo, legando a elas uma situação caótica. Mais do que ensejar um avanço tecnológico e administrativo, tal situação caracterizou as condições históricas para emergência do planejamento urbano, que, diante da concretude dos problemas nas cidades, constituiu uma das primeiras formas, abertamente aceitas pela sociedade capitalista, de intervenção sistemática do Estado sobre a produção ${ }^{175}$.

Com efeito, nas últimas três décadas do século XIX, emergiu na Inglaterra, inspirada pelos avanços e reformas na Alemanha, a definitiva tendência em torno de uma intervenção pública mais ambiciosa sobre o espaço urbano. Seu principal estímulo era uma crescente preocupação com a saúde pública e a clara percepção das deficiências do modelo habitacional da classe trabalhadora. Assim, assistidas ou direcionadas pela legislação nacional, as cidades empreenderam o melhoramento de seus sistemas de esgoto e distribuição de água. Também começaram a fazer sérias restrições às propriedades privadas e à construção de ruas e edificações, com objetivo de melhorar a insolação e a circulação de ar, além do tráfego de pedestres e veículos ${ }^{176}$.

Era também em torno da preocupação com a saúde pública que surgiram as primeiras técnicas de análise espacial e cartográfica, tão caras ao método do

\footnotetext{
${ }^{173}$ DEÁK, Csaba. The Partido dos trabalhadores in São Paulo. 18:41-52. Soundings. Inglaterra, 2001.

174 BENEVOLO, Leonardo. História da cidade. São Paulo: Perspectiva, 1993. p. 573.

${ }^{175}$ SUTCLIFFE, Antony. Towards the planned city. Nova York: St. Martin, 1981. p. 6.

${ }^{176}$ Ibidem. p. 50-51.
} 
planejamento urbano. Segundo Edmund Gilbert, pesquisas e livros sobre "a topografia das doenças" multiplicaram-se na Inglaterra a partir da segunda metade do século XIX. Um dos trabalhos mais emblemáticos é o do médico John Snow sobre a distribuição de cólera em Londres, na década de $1850^{177}$.

Snow mapeou todos os casos de uma epidemia de cólera e os plotou em um mapa com a distribuição das bombas de água de que se abastecia a população. Sua conclusão era evidente em só golpe de vista: os casos se concentravam nos arredores de uma bomba, localizada em uma rua chamada "Broad street", no distrito do Soho ${ }^{178}$.

Snow, então, publicou suas conclusões e o mapa em um panfleto e, assim, conseguiu apoio para a desativação da bomba, o que fez a epidemia arrefecer rapidamente. Com isso, fez do mapa não apenas um instrumento de análise, mas também um argumento político, conceito que permearia muitos trabalhos de análise urbana posteriores, como os empreendidos pelo franciscano Louis-Joseph Lebret e sues aderentes no Brasil, na Sociedade de Análises Gráficas e Mecanográficas Aplicadas aos Complexos Sociais (SAGMACS), na segunda metade do século XX.

Abaixo, uma reprodução do mapa de Snow. Nele, os pontos representam os casos de cólera e os " $x$ ”, as bombas de água.

\footnotetext{
177 GILBERT, Edmund W. Pioneer maps of health and disease in England. Geographical Journal. Vol. 124, n. 2. 172-183. 1958. p. 174-175.

178 Ibidem.
} 


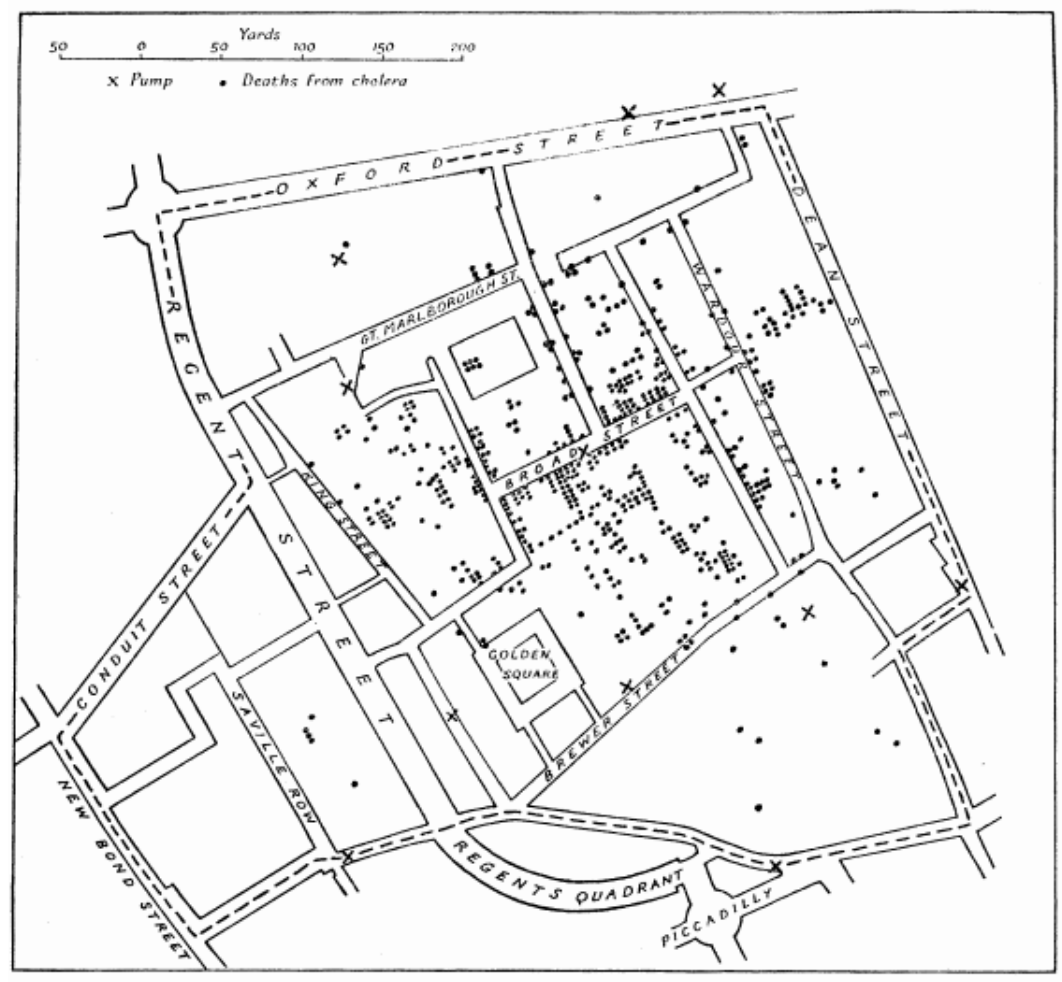

Figura 5 - Mapa de John Snow sobre a distribuição de cólera em Londres, 1850. Fonte: Gilbert (1958).

Durante o século $X X$, as vicissitudes do esquema pós-liberal culminaram no urbanismo modernista e na intensificação das atividades de planejamento. Preocupações com a eficiência produtiva e a salubridade do ambiente das cidades passaram, então, a propostas mais amplas e profundas de reformulação do espaço capitalista, com a crescente importância dada a questões como a habitação e o lazer da população como um todo ${ }^{179}$.

Essas preocupações permearam de modo explícito o urbanismo modernista, como nos trabalhos de Le Corbusier, que chegou a tomar as concepções de Charles Fourier como modelo para um de seus mais importantes projetos, as Unidades de Habitação de Marselha. Abaixo, um esboço de Le Corbusier, em que é possível notar a própria dissolução da propriedade privada da terra, em benefício do Bem-Estar coletivo.

${ }^{179}$ BENEVOLO, Leonardo. Op. Cit. 1993. p. 615. 


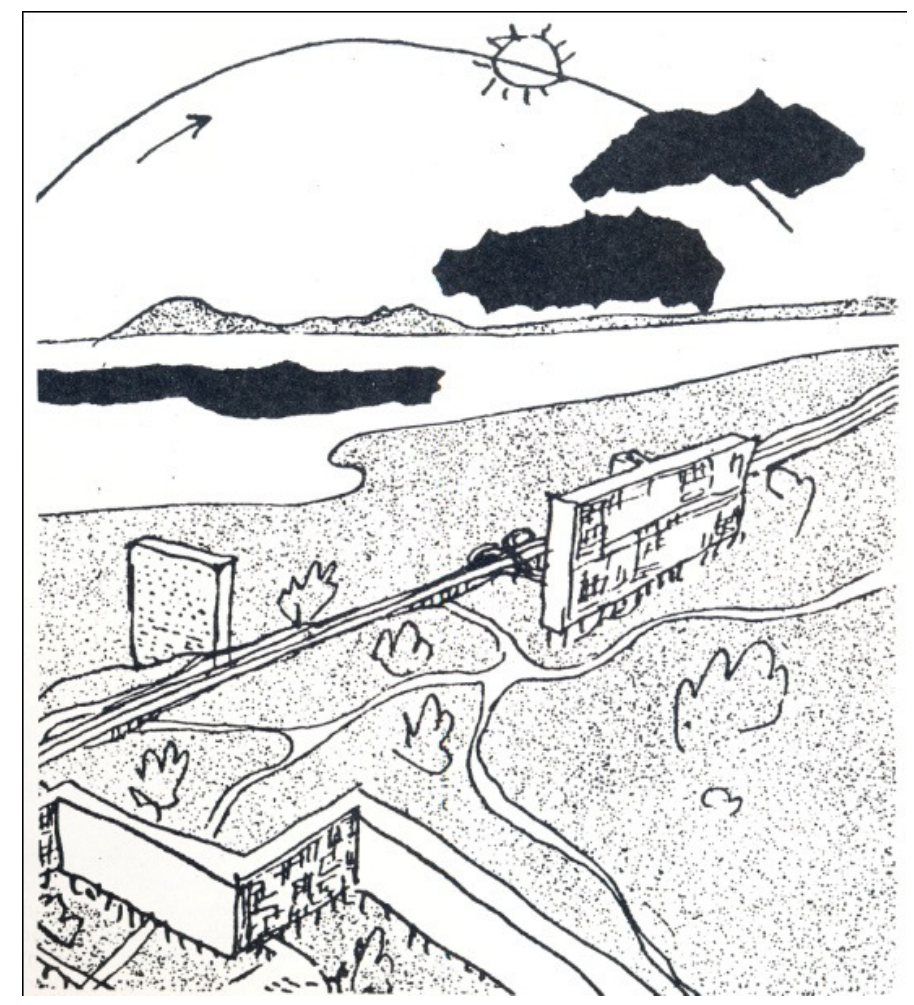

Figura 6 - Esboço de Le Corbusier representando a cidade moderna. Fonte: Benevolo (1993).

Cabe pontuar que todas essas experiências não eram episódios avulsos e articulavam-se tendo como núcleo a nova relação do Estado com a sociedade. Como observa Alyson Mascaro, na acumulação intensiva não apenas a ação estatal se dispersa por vários setores, mas também os mais diversos âmbitos da organização social se constituem e se irradiam tendo como núcleo o Estado, espalhando-se pelo todo social. Grupos, sindicatos, clubes, igrejas, empresas e entidades formam uma complexa organização, orquestrada em torno e pelo Estado, na promoção da superioridade do capitalismo e com resultados efetivos na expansão do Bem-Estar, do consumo e da condição salarial ${ }^{180}$.

Desse modo, o estágio intensivo e sua correspondente forma ideológica, a Social-Democracia, ou Estado de Bem-Estar Social, marcaram a fase mais

${ }^{180}$ MASCARO, Alyson Leandro. Estado e forma política. São Paulo: Boitempo, 2013. p. 121. 
distributivista do capitalismo. Não é por pouco que as três décadas posteriores à II Guerra Mundial ficariam conhecidas, segundo Eric Hobsbwam, como a "era de ouro" do capitalismo ${ }^{181}$.

Seu auge foi a década de 1960, período em que se institucionalizaram os chamados direitos sociais. Em 1966, a Convenção Internacional dos Direitos Econômicos, Sociais e Culturais da ONU estabeleceu o tratado multilateral sobre o tema, do qual praticamente todos os países do mundo são signatários e ratificantes. Comprometiam-se, com isso, à materialização das garantias fundamentais, incluindo os direitos do trabalho, à saúde, à educação e a elevação dos padrões de vida. Ainda que esse comprometimento tenha tomado efeito apenas em alguns aspectos dos países centrais, formalmente foi incorporado pelo mundo afora como um sinal de progresso, a exemplo do artigo sexto da constituição brasileira de 1988, sobre direitos sociais.

Para Thomas Marshall, os direitos sociais representam o terceiro degrau da evolução da cidadania. Diferentemente dos direitos civis - negativos em sua essência contra o Estado Absolutista e a velha ordem social feudal -, os direitos sociais implicavam uma ação concreta, que extravasava os limites da atuação pelo mercado. Criavam um direito universal a um rendimento real que não era provido pelo mercado e, dessa forma, submetia seu princípio de constituição - de constituição pelo mercado - à justiça social ${ }^{182}$.

Robert Castel vê nesse período a emergência de um "Estado de crescimento". Trata-se da articulação de dois parâmetros fundamentais: o crescimento econômico e o desenvolvimento do "Estado social" - de Bem-Estar -, que acompanharam a evolução do que chamou de "sociedade salarial". Em seu entendimento, o Estado

\footnotetext{
${ }^{181}$ HOBSBAWM, Eric. A era dos extremos. São Paulo: Companhia das Letras, 1995. p. 253-255.

182 MARSHALL, Thomas. Citizenship and social class. In: MANZA, Jeff; SAUDER, Michael (Org.). Inequality and society. Nova York: W. W. Norton and Co., 2009. p. 153-154.
} 
instalou-se no coração desse novo sistema social e estava predestinado a crescer ainda mais ${ }^{183}$.

Por meio da expansão da seguridade social, da regulação do equilíbrio econômico e da provisão direta de bens e serviços, o Estado instituiu uma nova condição aos trabalhadores, tributária do crescimento econômico. Era, porém, uma condição frágil, uma vez que qualquer interrupção do crescimento seria interpretada como tendo causa a sofisticada montagem dos direitos sociais e da regulação pelo Estado $^{184}$.

Esse movimento também pode ser compreendido de maneira dialética. O ápice do Estado de Bem-Estar e a institucionalização dos direitos sociais coroam o desenvolvimento da acumulação intensiva do capitalismo. Nesse momento, o antagonismo do Estado na sociedade capitalista se explicita e desperta uma reação, uma negação do princípio social ameaçado. Isto é, seguindo o imperativo da reprodução da ordem social baseada na máxima expansão da forma-mercadoria, as instituições são reformuladas de modo a encaminhar um suposto restabelecimento da primazia do mercado na organização da produção. É o momento do desmonte das construções sociais-democratas e do surgimento da retórica neoliberal ${ }^{185}$.

\footnotetext{
${ }^{183}$ CASTEL, Robert. From manual workers to wage laborers. Nova Jersey: Transaction Publishers. 2003. p. 343-352.

184 Ibidem.

${ }^{185}$ DEÁK, Csaba. Op. Cit. 2016. p. 121.
} 


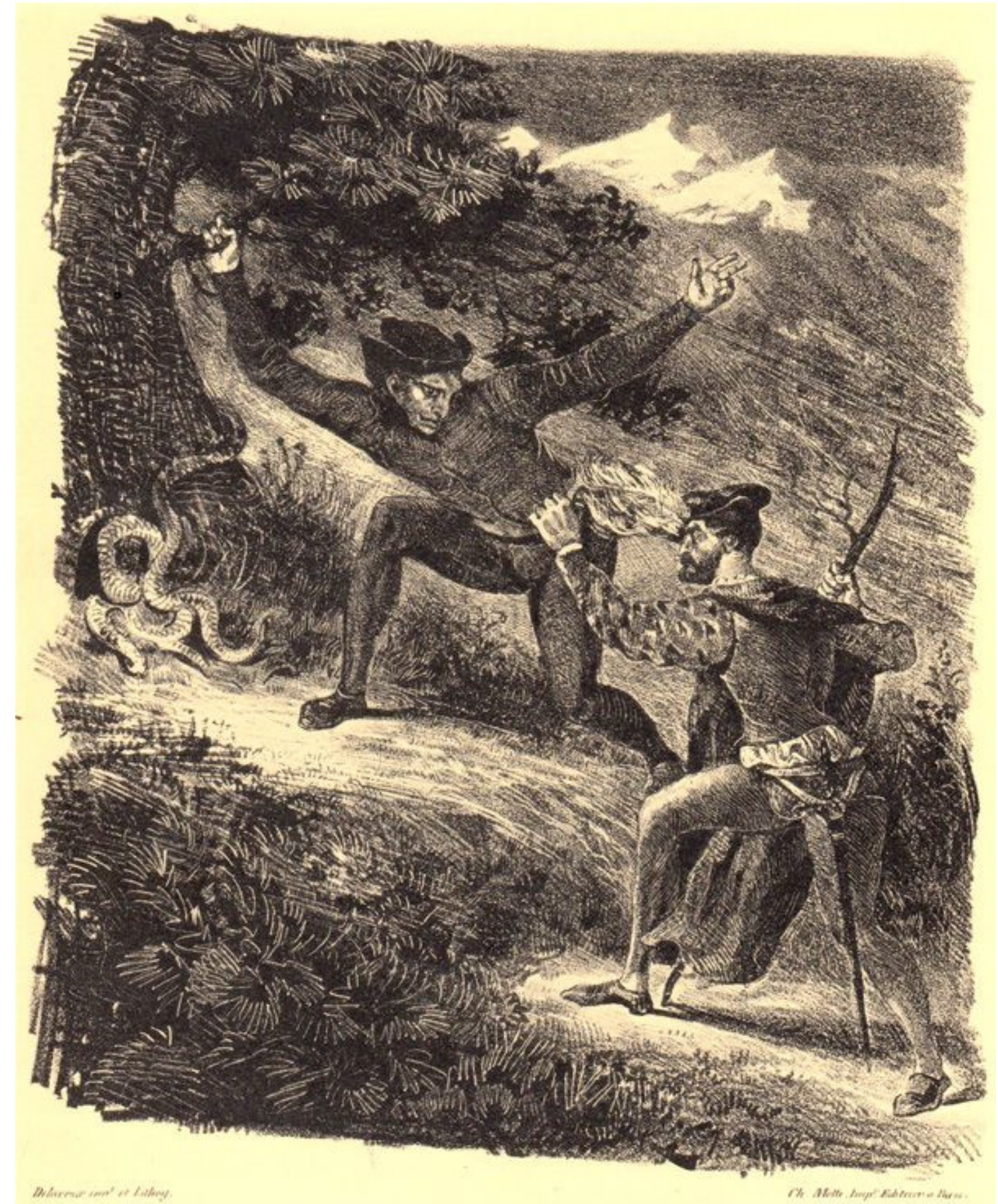

MEPHISTOPHELES: Our goal by this road still is far away.

Fausto. Eugene Delacroix, 1828.

Disponível em oldbookillustrations.com 
2.5. Neoliberalismo e o debate sobre o pós-fordismo

A crise contra a qual se levantam os chamados argumentos neoliberais não é propriamente um estágio da evolução do capitalismo. É, antes, o avivamento de suas contradições internas, que se apresentam mais claramente no estágio intensivo de acumulação - ou no fordismo, como também se refere ao período a abordagem regulacionista. A intervenção estatal, ainda que necessária para ampliação do mercado, constitui uma negação ao seu funcionamento, pois ao englobar grande parte da produção na forma de infra-estruturas, restringe o âmbito da produção de mercadorias, ameaçando, portanto, a ordem capitalista, fundada na preeminência do mercado como princípio de regulação social ${ }^{186}$.

Em meio a tal quadro, teve origem a ideologia neoliberal. Suas primeiras concepções remontam às críticas à social-democracia e ao keynesianismo, feitas por economistas como Friedrich Hayek, Milton Friedman e Ludwig Von Mises, em meados do século XX. Foi durante as décadas de 1980 e 1970, entretanto, que o neoliberalismo ganhou proeminência e materialidade, principalmente com as experiências inglesas e norte-americanas de Margaret Thatcher e Ronald Reagan ${ }^{187}$.

Conhecidas como teses neoclássicas, as proposições neoliberais advogavam políticas de ajustamento fiscal e monetário, desregulamentação, privatizações e o corte de medidas consideradas assistencialistas. Seus principais centros de divulgação seriam a Escola Austríaca de Economia e a Universidade de Chicago escola de Chicago -, da qual deriva o termo pejorativo "Chicago-boys", em referência aos economistas latino-americanos, em especial chilenos, treinados na Universidade de Chicago sob a orientação de Milton Friedman e que, durante o regime de Pinochet, implantaram uma das primeiras experiências neoliberais.

\footnotetext{
${ }^{186}$ Ibidem.

${ }^{187}$ ANDERSON, Perry. Balanço do neoliberalismo. In: SADER, Emir; GENTILI, Pablo (Org.). Pós-neoliberalismo: as políticas sociais e o Estado democrático. Rio de Janeiro: Paz e Terra, 1995. p. 10.
} 
Em essência a proposta do neoliberalismo é, em virtude do crescimento do Estado, a tentativa de recuperar a primazia do mercado na regulação da produção, lançando mão, para tanto, de expedientes como as privatizações. Contudo, uma vez que a produção de infra-estruturas coube ao Estado justamente devido à insuficiência do mercado em provê-las, a privatização não é o mesmo que a remercadorização, continuando a depender do Estado as atividades que, em tese, foram retomadas pelo mercado $^{188}$.

Dessa forma, as contradições do capitalismo não teriam continuidade, como também se aprofundariam. Embasado em dados do Banco Mundial, Csaba Deák mostra como a participação dos gastos estatais no PIB dos principais países capitalistas aumentou consideravelmente durante o século XX, mesmo após a implantação das políticas neoliberais ${ }^{189}$.

De acordo com Robert Boyer, as décadas de 1970 e 1980 caracterizaram o que chama de "os vinte anos dolorosos". Marcaram a ruptura com a acumulação intensiva do fordismo, com a forte desaceleração dos ganhos de produtividade. Foi a troca de um modelo que possibilitou combinar margens elevadas e estáveis de lucro com a progressão de renda dos assalariados, por um desempenho medíocre nos anos 1980 e $1990^{190}$.

Para Perry Anderson, em termos econômicos o neoliberalismo foi um grande fracasso. Apesar de todos os esforços políticos e os sacrifícios sociais, o neoliberalismo não foi acompanhado por mudanças favoráveis nas taxas de crescimento econômico ${ }^{191}$.

$\mathrm{Na}$ esfera das questões urbanas, o neoliberalismo significou a desconstrução do planejamento global das cidades. Como observa Otília Arantes, a derrocada do planejamento deu lugar a intervenções pontuais e fragmentárias que deveriam, como

\footnotetext{
${ }^{188}$ DEÁK, Csaba. O mercado e o Estado na organização espacial da produção capitalista. Espaço e Debates. Número 28, Ano IX, páginas 18-27. São Paulo: NERU, 1989. p. 25.

${ }^{189}$ Idem. Op. Cit. 2016. p. 122.

190 BOYER, Robert. Teoria da regulação: os fundamentos. São Paulo: Estação Liberdade, 2009. p. 103.

${ }^{191}$ ANDERSON, Perry. Op. Cit. 1995. p. 10.
} 
em uma espécie de "metástase benigna", na expressão de Oriol Bohigas, irradiar isto é, por meio de processos espontâneos de mercado - a requalificação e os recursos investidos em recortes espaciais criteriosamente escolhidos ${ }^{192}$.

Oriol Bohigas foi um dos membros da equipe que concebeu o projeto da Vila Olímpica de Barcelona, entre as décadas de 1980 e 1990. Em essência, o projeto consistiu no remodelamento e modificação do uso do solo de um distrito industrial e operário de Barcelona, o Poblenou. Seu resultado foi a conversão da área em um pólo de atração turística e em um centro financeiro, que levaram a expropriações em massa, à concentração de investimentos e à gentrificação.

Por suas qualidades inovadoras e completa aderência ao ideário neoliberal, o projeto de Barcelona transformou-se em um modelo das então chamadas propostas de "revitalização urbana". Essas propostas foram replicadas em muitas cidades como intervenções "atuais" e "econômicas" - de pequena escala -, a exemplo do projeto "Puerto Madero", em Buenos Aires, e o "Porto Maravilha", no Rio de Janeiro. No Brasil, institucionalizaram-se na figura das Operações Urbanas Consorciadas, em consubstanciação com diversos outros "instrumentos de mercado" que passaram a integrar a nova prática do urbanismo - outorga onerosa, transferência do potencial construtivo... Ganharam, além disso, pretensas formulações teóricas, como nas concepções de Jaime Lerner sobre "acupuntura urbana".

No campo das formulações, há, ainda, a gigantesca influência de urbanistas como Jane Jacobs e Jan Ghel. Propagados como críticos do urbanismo modernista e do planejamento urbano do século $\mathrm{XX}$, seus trabalhos defendem explicitamente intervenções pontuais e apenas incrementais nos espaços urbanos. Ademais, sua bandeira em defesa de um estilo de vida específico, quando não conservador, encoberta os conflitos em torno dos quais se estruturam as cidades, relega a importância das infra-estruturas urbanas - como as redes de transporte - e, sobretudo, esvazia a questão da reprodução da força de trabalho, sobre a qual a discussão do

${ }^{192}$ ARANTES, Otília. Urbanismo em fim de linha. São Paulo: EDUSP, 1998. p. 134 
planejamento urbano se constituiu historicamente - como comentado no capítulo anterior.

A verdade, conclui Otília Arantes, é que tais medidas e formulações constituíram formas de manutenção da realidade urbana existente, e não de sua superação. Por trás do ideal de preservação, congelam a dinâmica das cidades, escamoteiam conflitos, concentram recursos e reproduzem a precariedade de outras regiões $^{193}$.

Assim, o único efeito do neoliberalismo foi dissimular a crise capitalista, deixando inalterado o processo subjacente de transformação social e econômica, que adentra o século XXI sem qualquer definição. Se compreendidas dessa maneira, as tentativas do neoliberalismo em encapsular o Estado em um compartimento mínimo da reprodução social, ainda que reconhecidamente necessário, estarão sempre fadadas ao fracasso.

O restabelecimento do mercado como principal agente da organização da produção depende da reincorporação, em seu escopo, de atividades produtivas - e reprodutivas - que foram encapadas pelo Estado justamente pela deficiência do mercado em encaminhá-las. E isso não significa apenas as áreas de atuação tradicionais do Estado, que, independente das proporções que assumam, podem ser estáticas. O antagonismo dialético no capitalismo reside no movimento que o faz acionar recursivamente o Estado.

O que é sustentado nesta tese é que, incapazes de garantir a ampliação das condições de reprodução da força de trabalho, seja pela insuficiência de universalizar bens e serviços - de disponibilizar a preços que não comportam lucro -, seja pela necessidade de minorá-los, os postulados neoliberais atingem frontalmente o elemento que possibilita não apenas a produção, mas sua ampliação: a produtividade do trabalho.

193 Ibidem. p. 135-136. 
Essa hipótese encaixa-se dentro da interpretação de Deák para a crise do capitalismo, entendida como a evolução da dialética entre suas instâncias de regulação, o mercado e o Estado, no avanço do estágio intensivo de acumulação. Tal estágio ou regime de acumulação, por sua vez, é um conceito derivado dos trabalhos de Michel Aglietta e da escola da regulação capitalista. Também chamado de fordismo, esse conceito permeia o debate sobre essa mesma crise do capitalismo, que se convencionou chamar de o debate sobre o "pós-fordismo". A seguir, o que se busca expor são considerações sobre como as conclusões deste trabalho e das teses da dialética do mercado e do Estado podem ser situadas em tal debate.

$\mathrm{Na}$ introdução de "O longo século XX", Giovanni Arrighi aponta um debate que se sobreleva nas discussões contemporâneas da economia política, o debate sobre o pós-fordismo. Trata-se de questionamentos acerca das variações espaciais e temporais do capitalismo, em especial, sobre os desdobramentos da crise que se instalou na economia mundial a partir da década de $1970^{194}$.

Esse debate está lastreado nas categorias marxistas e nas considerações da abordagem regulacionista. De um modo geral, as discussões tendem à exploração dos efeitos da desintegração do regime de acumulação intensiva do capitalismo, ou fordismo.

Segundo Alyson Mascaro, as condições de que resulta o fordismo se alteraram substancialmente a partir dos anos 1970. O papel preponderante do Estado na manutenção da produtividade e na regulação do equilíbrio econômico deu lugar ao constrangimento sistemático das condições de Bem-Estar e à precarização do trabalho. O mais importante, continua o autor, é que esse período não se estabelece como decorrente de um "evento-símbolo" - como choque do petróleo, arrefecimento da Guerra-Fria... -, mas sim de uma crise intrínseca ao fordismo e ao capitalismo de um modo geral ${ }^{195}$.

\footnotetext{
${ }^{194}$ ARRIGHI, Giovanni. O longo século XX. Rio de Janeiro: Contraponto, 1996. p. 1-4.

${ }^{195}$ MASCARO, Alyson Leandro. Estado e forma política. São Paulo: Boitempo, 2013. p. 120-124.
} 
Na observação de Arrighi, uma parte dos estudiosos que, de algum modo, circundam a abordagem regulacionista, apesar das muitas elaborações, mantém-se céticos quanto aos rumos do pós-fordismo. Outra parte, a exemplo de David Harvey, acredita que o pós-fordismo significa a emergência de um novo modo de desenvolvimento do capitalismo ${ }^{196}$.

Segundo David Harvey, o regime "pós-fordista" seria caracterizado por uma performance econômica de alta flexibilidade e pela redução de direitos sociais. $O$ diagnóstico da sociedade capitalista teria culpado a rigidez do modelo fordistakeynesiano, com suas elevadas taxas de imobilização de capital e o estrito controle de mercados - financeiro e de trabalho -, pelo pouco significante ritmo de crescimento econômico após o boom do período posterior a $1945^{197}$.

Uma reorientação da ação do Estado e do capital pôs em prática, então, uma série de expedientes para flexibilização da produção e dos mercados. Entre eles figuravam medidas como as privatizações, a desregulamentação de mercados e o recurso a diferentes regimes produtivos e à precarização das relações salariais, como o trabalho em domicílio e "conta-própria""

Para Harvey, a crise do fordismo foi uma crise de superprodução - ou sobreacumulação -, que seria solucionada por mecanismos como as desvalorizações de preço, calibrações nas políticas monetária e fiscal e, principalmente, pelo que o autor chama de "ajustes espaciais". Com o objetivo de ampliar a produção de excedente, o capital procederia a expansões geográficas de modo a incorporar a força de trabalho dos países terceiro-mundistas, disponível, mais barata e consideravelmente desprovida de direitos. Lançaria mão também do avanço tecnológico no campo das telecomunicações para subordinar relações de trabalho que passariam a acontecer fora das estruturas produtivas, o caso do trabalho em domicílio

\footnotetext{
${ }^{196}$ ARRIGHI, Giovanni. Op. Cit., 1996. p. 1-4.

197 HARVEY, David. The condition of postmodernity. Oxford: Blackwell, 1990. p. 125-173.

198 Ibidem.
} 
ou da "uberização", por exemplo. Dessa forma, a rigidez do fordismo seria superada e encaminharia um regime de acumulação flexível ${ }^{199}$.

Nesse sentido, a idéia de ajuste espacial de Harvey poderia, ainda, ser cotejada ao funcionamento de uma "economia-mundo". Tal conceito remete aos trabalhos de Immanuel Wallerstein e com ele se quer expressar a idéia de um sistema internacional em que as múltiplas existências nacionais estão subordinadas ao princípio de uma mesma rede produtiva ${ }^{200}$.

No caso do pós-fordismo, explica Mascaro, as condições de regulação e acumulação pós-fordistas engendram um processo que atinge, ao mesmo tempo, economias de todo o mundo e que se apresentam em distintos modos de desenvolvimento material e institucional. A dinâmica do capital, das mercadorias e das finanças faz com que o papel da política e do direito nacional seja pautado pela conjuntura global. Contudo, isso não significa uma reprodução alheia aos Estados nacionais, mas sim um novo arranjo desses ${ }^{201}$.

Revisitando a problemática da crise do fordismo, nesse mesmo enquadramento da economia-mundo, Arrighi a exploraria mediante uma leitura histórica do capitalismo, dando-Ihe os contornos de longa-duração. Isto é, para Arrighi, a crise contemporânea do capitalismo remontaria a seu surgimento e desenvolvimento desde o século XV e mais precisamente no último quarto do século XIX (eis o porquê de o "longo século XX"). Combina, para tanto, as pesquisas de Braudel às esquematizações de Marx, relativas ao ciclo de reprodução do capital (D-M-D - Dinheiro-Mercadoria-Dinheiro ${ }^{202}$.

Em síntese, segundo Arrighi, a crise de superprodução em uma determinada formação social capitalista financiaria, por meio da liquidação do capital imobilizado nessa estagnada economia, um ciclo de expansão material em outra nascente formação social capitalista. Posta em perspectiva histórica, a crise do fordismo

\footnotetext{
199 Ibidem. p. 181-188.

${ }^{200}$ WALLERSTEIN, Immanuel Maurice. The modern world system. Vol. I. Nova York: Academic Press, 1974. p. 15.

${ }^{201}$ MASCARO, Alyson Leandro. Op. Cit. 2013. p. 124-125.

${ }^{202}$ ARRIGHI, Giovanni. Op. Cit., 1996. p. 1-27.
} 
significaria a passagem da economia americana a um ciclo de expansão financeira, em decorrência do esgotamento de seu ciclo de expansão material, que, por sua vez, teria sido antecedido e financiado pelo ciclo de expansão financeira da Inglaterra em fins do século XIX, que, recursivamente, seria antecedido pelos ciclos holandês e italiano.

De tal modo, o debate sobre o pós-fordismo parece se estruturar sobre alguns elementos. Em primeiro lugar, baseia-se nos chamados "conceitos intermediários" da escola regulacionista para dar conta das transmutações temporais e variações espaciais internas ao modo de produção capitalista. São os regimes de acumulação extensiva e intensiva (fordismo) e os modos de regulação (as formas ideológicas e institucionais que pilotam tais regimes ${ }^{203}$.

Consubstanciados, esses conceitos formam os "modos de desenvolvimento", categorias de mediação que explicam as variações, as crises e a estabilidade do capitalismo ao longo de sua história. Essa história é entendida, cabe ressaltar, não como um ciclo resiliente que a perpetua infinitamente, mas como uma dissolução paulatina que comporta mecanismos de regularização (ou regulação - e daí o termo regulacionismo $)^{204}$.

Há também a percepção de que a dinâmica do pós-fordismo, e sua história subjacente, significam, de alguma forma, o movimento específico de uma economiamundo (ajustes espaciais, ciclos de expansão...). Tal movimento perpassa a evolução das grandes finanças, mas também da materialidade tangível das formas de trabalho a exemplo da precarização da condição dos assalariados contra as formas passadas do Bem-Estar. Trata-se ainda da compreensão de um processo social que se constitui no andamento dos séculos e de conflitos que envolvem, de algum modo, o jogo entre os âmbitos da organização produtiva, o mercado e o Estado.

\footnotetext{
${ }^{203}$ BOYER, Robert. Op. Cit. 2009. p. 81-83.

204 Ibidem.
} 
Sobre essa base comum, as partes desse debate esforçam-se em lançar suas visões sobre as implicações desse processo e sobre seu devir. Pelo exposto, acreditase que as teses da dialética do mercado e do Estado são pertinentes a tal debate e às questões que levanta, o que, por conseqüência, enquadra nele também o conteúdo deste trabalho. Assim, como desfecho deste capítulo, a relação entre essas teses e o debate do pós-fordismo abrem a possibilidade para cinco observações.

(1) Para Deák, a crise da acumulação intensiva é a agravação da dialética do mercado e do Estado e constitui movimento final do desenvolvimento capitalista. Portanto, se fosse possível posicionar suas conclusões nas discussões sobre o pósfordismo, a proposição é de que esse último não é propriamente um estágio da evolução capitalista, tampouco representa sua reimposição em novos moldes, não sendo seu seguimento outra coisa que não a própria transformação do modo de produção capitalista.

(2) Como muitas contribuições desse debate, o entendimento de Deák é de que a compreensão da crise contemporânea envolve a abordagem de toda a história do capitalismo, desde sua gênese na crise do feudalismo. Seu ponto incomum, contudo, é a característica dialética dessa evolução, marcada pelo antagonismo entre o mercado e o Estado, como instâncias de regulação da produção social. Apesar de Arrighi se referir à "dialética entre mercado e planejamento", sua concepção é mais pendular do que propriamente dialética, correspondendo aos ciclos de acumulação que abarca em seu estudo ${ }^{205}$.

(3) No entanto, se permitido um cotejamento entre as interpretações de Deák e Arrighi, a sucessão dos ciclos internacionais de expansão material e financeira poderia ser lida como os desdobramentos de uma verdadeira dialética entre âmbitos de regulação da produção, que atravessa um sistema de Estados nacionais de variadas fases e modos de desenvolvimento capitalista. Ao esgotar seu regime extensivo - e, portanto, sua maior parcela de geração de excedente - o relativo baixo potencial de

${ }^{205}$ ARRIGHI, Giovanni. Op. Cit., 1996. p. 52. 
acumulação de um determinado Estado induz, de um lado, a expansão do âmbito estatal com fins a regular seu equilíbrio econômico, e, de outro, a evasão dos capitais que, em busca de melhores taxas de rentabilidade, estabelecem um fluxo financeiro internacional de modo a patrocinar a acumulação extensiva de outro Estado.

(4) Isso põe a reprodução da força de trabalho como elemento importante dessa análise, uma vez que é explicação chave do elevado excedente produtivo na acumulação extensiva e de sua transição a um regime intensivo. No extremo, a acumulação extensiva e sua relação com a reprodução dos trabalhadores como base das diferentes taxas de excedente entre Estados nacionais poderia ser pensada como um limite - e um rumo - aos fluxos financeiros internacionais, aos ajustes espaciais de Harvey e aos ciclos de expansão de Arrighi.

Medida pelas taxas de urbanização mundiais, a acumulação extensiva tem seus dias contados e poucas alternativas geográficas a que possa se direcionar além da China, da Índia e da África. Sem acumulação extensiva não há "diferença de potenciais" para que haja um fluxo financeiro internacional e, assim, para que se mantenha qualquer regime capitalista nele baseado.

(5) Nesse ponto, os conceitos de acumulação extensiva e intensiva começam a perder sua força como componentes teóricos da análise da dialética social. Como a renda - sendo categoria do feudalismo - perde valor explicativo no capitalismo, as categorias do capitalismo acarretam o mesmo na investigação dos desdobramentos da crise capitalista, na sua dissolução. As categorias da organização e da produção social no capitalismo morrem com ele, e não há esperança de que digam muita coisa sobre o que está por vir.

Além disso, ainda que os conceitos da escola regulacionista abram um grande caminho nessa investigação, ressentem a mesma problemática das categorias estanques de Marx, como o modo de produção. Como subdivisões da categoria modo de produção - em especial do modo de produção capitalista -, os conceitos da escola regulacionista prestam-se a uma coerente generalização de seus estágios 
intermediários e de sua multiplicidade espacial, mas sofrem, como diria Balibar, de "problemas de borda".

Quer dizer, parte essencial da transição e da variabilidade do capitalismo se resolve justamente na sobreposição entre um modo de produção e outro, entre um regime de acumulação e outro, nas nuances entre uma e outra formação social. No estudo do intermediário, da transição e da variabilidade, o recurso à idéia de "predominância" não faz sentido. Assim, as categorias discretas apresentam limites na exploração do processo social, essencialmente contínuo. É por isso que o estruturalismo de Althusser e Balibar lança mão de um conceito suplementar, capaz de capturar essa continuidade: o conceito de "reprodução".

Nesta monografia, a escolha por enfocar um aspecto específico da reprodução social, a reprodução da força de trabalho, deve-se à sua qualidade de mediação entre os tantos tópicos da crise contemporânea do capitalismo e à sua natureza motriz no acionamento dos antagonismos dialéticos que a configuram. Isto é, enfeixa em uma mesma direção conceitual a análise das feições mais complexas e abstratas das grandes finanças, da ideologia e do desenvolvimento institucional e, ao mesmo tempo, do palpável cotidiano da reprodução da força de trabalho, dando-lhe, com isso, alcance teórico na investigação dos desdobramentos do capitalismo. É um esforço de buscar na história tanto o "tempo do mundo" quanto as "estruturas do cotidiano", como nas palavras de Braudel.

Ademais, a reprodução da força de trabalho, por seu caráter elementar na reprodução social, impõe necessidades que permeiam a existência e a transformação de todas as formações sociais. O questionamento sobre como ela se realiza, se realizou e se realizará está, portanto - na visão deste estudo -, na base do caminho para a compreensão do conteúdo específico de cada processo social e de sua transformação dialética, o que incluí a questão sobre a sucessão do pós-fordismo.

A abordagem da história européia por meio da leitura da reprodução da força de trabalho, desde sua Antiguidade, teve como objetivo esboçar um exercício dessa 
interpretação no tempo, ao longo da transmutação entre diferentes sociedades e modos de produção. Por um imperativo da reprodução social - aqui lida no aspecto da reprodução do trabalho -, a Antiguidade criou o feudalismo, que criou o capitalismo que, por fim, criou seus próprios antagonismos. A seguir, breves conjecturas sobre o processo histórico de Brasil e China visam a uma tentativa semelhante no espaço, por meio da discussão das especificidades de tais processos na constituição e no desdobramento da conjuntura contemporânea. 


\section{BRASIL E CHINA}

\subsection{Colônia e escravidão}

O roteiro seguido até aqui leva a uma observação sobre a história do Brasil. Desde sua origem como colônia até os dias atuais, a formação social brasileira nunca teve como princípio estruturante das relações sociais uma preocupação com a reprodução da força de trabalho. Essa precisou ser continuamente recomposta pelo afluxo de trabalhadores estrangeiros - por mais de três séculos escravos - e, durante o século XX, pelo contingente da urbanização. Com a permissão da linguagem, o Brasil é como Piaimã, um gigante comedor de gente.

Uma evolução permeada por distintas relações de produção, deslocamentos do poder entre uma e outra classe dominante, particularidades regionais, além de inúmeras transmutações políticas e institucionais, fizeram com que a história do Brasil quase sempre precisasse ser vista como uma composição de recortes, cujos motores históricos se encerram nesses pequenos fragmentos do tempo. $O$ ensaio a seguir é uma tentativa de contá-los por meio de uma única linha narrativa, dialética e baseada no que se imagina ser um traço fundamental, que atravessa toda a existência da sociedade brasileira e ora a impõem uma crise. Trata-se do princípio da não reprodução da força de trabalho e da atual necessidade de transformá-lo.

Esse princípio é muito claro no período colonial, em que a sociedade brasileira erigiu-se fundada no trabalho escravo. A escravidão no Brasil, contudo, tem características próprias. Compreendê-las exige enxergá-las como emersas do sistema colonial e mercantilista. Mais do que isso, é preciso reconhecer que aqui esse sistema gerou, muito cedo e ao contrário de um mero empreendimento mercantil, um organismo social autônomo, animado por uma lógica peculiar, ainda que não formalmente independente.

Um dos eminentes historiadores a trabalhar o primeiro componente dessa compreensão foi Fernando Novais. Para Novais, o sistema colonial derivava do 
funcionamento mercantilista. O comércio de longa distância com sociedades já estabelecidas na Ásia há milênios não apenas levou ao "descobrimento" das Américas, como ensejou também o rearranjo do simples ato de comerciar, orientando-o à produção direta nos territórios americanos ${ }^{206}$. Assim, antes de entender a Colônia, é preciso entender o sistema que lhe deu origem.

Deve-se ter em mente também que mercantilismo não significa capitalismo nem uma forma embrionária dele. Como explica Ellen Wood, o princípio dominante do grande comércio não era o mercado e a acumulação capitalistas - muito menos era baseado nas relações de produção capitalistas. O que o organizava era o que os economistas chamam de arbitragem - de preços -, a idéia de tirar vantagens sobre compradores e fornecedores, de "comprar barato e vender caro" ("buying cheap, selling dear") $)^{207}$.

Tal situação, na verdade, estava relacionada a uma debilidade das potências comerciais, que não controlavam a produção. Guy Bois, tratando especificamente da atividade de mercadores na Europa, argumenta que sua existência dependia do estabelecimento de monopólios, inclusive originados das finanças e do crédito, pois sem isso não tinham qualquer poder no comércio, alicerçado na produção independente e em uma realidade em que o consumo pautava-se, em grande medida, pela subsistência local ${ }^{208}$.

O comércio ultramarino era ainda mais frágil. Estava sempre à mercê da grande conjuntura e de sociedades complexas e sofisticadas, não raro, mais poderosas. Apoiava-se, por isso, em expedientes extra-econômicos, como a força e, sobretudo, o Estado, para manter o monopólio das rotas comerciais, o que lhe permitia controlar, senão as pontas, o meio do circuito.

\footnotetext{
${ }^{206}$ NOVAIS. Fernando. Portugal e Brasil na crise do antigo sistema colonial. São Paulo: Hucitec, 1989. p. 67-70.

${ }^{207}$ WOOD, Ellen Meiksins. The origin of capitalism. Nova York: Verso, 2002. p. 78.

208 BOIS, Guy. On the crisis of the Late Middle Ages. The Medieval History Journal. Vol. 1, 2. 311-321. 1998. p. 317-321.
} 
No comércio ultramarino, a Ásia abrigava as maiores oportunidades, pois, em meados do milênio, era onde se concentrava a maior parte da produção mundial. Com isso, a região era também fornecedora de produtos que o continente europeu muito precariamente conseguia suprir. Angus Maddison estima que, por volta de 1500, mais de $60 \%$ da produção mundial estava na Ásia, sendo 50\% vindos da China e da Índia. Essa proporção só seria alterada a favor da Europa e do ocidente depois do século $X I X^{209}$.

As primeiras iniciativas de comércio de longa distância com o Oriente nesse período foram empreendidas pelas repúblicas italianas (Florença, Veneza e Gênova). Consistiam em rotas terrestres e marítimas que, ao norte, seguiam através do mar negro e pelo continente asiático. Já ao sul, estendiam-se através do nordeste da África, pela Síria, Egito, Mar Vermelho e Oceano Índico. Com o declínio do império mongol e a ascensão dos otomanos em ambas as embocaduras, as rotas passaram a sofrer sérias restrições.

Logo uma rota alternativa, que contornava o continente africano, tornou-se vantajosa e sua exploração foi liderada pelos portugueses. Isso não antes de uma cuidadosa preparação que durou décadas e envolveu extenso incentivo estatal. Tratase da criação de escolas de navegação, da revolução da ciência astronômica e cartográfica, do desenvolvimento de instrumentos específicos para navegação no hemisfério sul - o astrolábio que, diferente do quadrante baseado na estrela polar, baseava-se no sol -, do aprimoramento na técnica de construção de navios, de viagens exploratórias por rotas convencionais, de estudos sobre funcionamento das sociedades asiáticas, da preparação de intérpretes e até de espionagem ${ }^{210}$ e 211.

O sucesso das navegações portuguesas colocou o sistema atlântico - o oceano e a costas africana e brasileira - como peça chave do projeto comercial da

\footnotetext{
${ }^{209}$ MADDISON, Angus. The world economy: a millennial perspective. Vol. I. Paris: OECD Publishing, 2006. p. 263.

210 Ibidem. p. 59-66.

${ }^{211}$ BURAQUE DE HOLANDA, Sérgio et all. História Geral da Civilização Brasileira. Vol. I. Rio de Janeiro: Bertrand Brasil, 2007. p. 33-43.
} 
Coroa na Ásia. Nasceu, assim, o Brasil, fruto da razão mercantilista e como parte de uma grande e longínqua ambição. Nesse sentido, é possível pensar as primeiras fortalezas da costa brasileira não apenas como resguardo de seu interior, mas também, e talvez principalmente, como um meio de assegurar a exclusividade da rota do Atlântico. De qualquer modo, ainda dentro dessa razão e desse sistema, o Brasil, em pouco tempo, assumiria uma nova função.

De acordo com Luiz Felipe de Alencastro, apesar do êxito preliminar, Portugal teve dificuldades em sustentar seu império de circulação de mercadorias no oriente. A concorrência de outras potências e a ausência de um excedente regular para as trocas forçaram o deslocamento de uma economia comercial na Ásia para uma economia produtiva no Atlântico Sul. Sem uma base social previamente existente para essa produção, os portugueses inovaram com a criação de um arranjo artificial: uma colônia produtiva no Brasil, alimentada por força de trabalho escrava vinda da África, o que consubstanciava as duas margens do Atlântico ${ }^{212}$.

Era uma forma de continuar obtendo barato - e regularmente - o que se vendia caro na Europa. Seu sustentáculo era a escravidão. Conseqüentemente, a fonte da riqueza não era uma verdadeira produção, e sim uma transferência dessa da força de trabalho da África que, não sendo reproduzida - como todo trabalho escravo e causa dessa transferência -, precisava ser continuamente reincorporada.

Assim, para Alencastro, a colonização portuguesa constituiu um espaço econômico e social bipolar. Uma zona de produção escravista no Brasil e outra de exportação de força de trabalho na África. E isso é tão essencial que o Brasil, ao longo de toda história moderna, foi, de modo discrepante, o maior importador de trabalhadores escravos do mundo, superando, em grande volume, a Europa, a América espanhola e inglesa e marcando, por isso, suas características contemporâneas ${ }^{213}$.

\footnotetext{
${ }^{212}$ ALENCASTRO, Luiz Felipe. 0 trato dos viventes. São Paulo: Companhia das letras, 2000. p. 30.

${ }^{213}$ Ibidem. p. 9, 42-43.
} 
Para Jacob Gorender, o que passou a existir no Brasil constituiu mesmo um novo modo de produção, ou ao menos uma formação social de bases muito específicas e inusitadas. Essa é a tese do escravismo colonial. Apesar das polêmicas que possa suscitar, o argumento de Gorender é esclarecedor em mostrar como elementos materiais muito definidos foram decisivos em afastar o desenvolvimento inicial do Brasil de uma evolução capitalista e burguesa.

O termo inovação, acima referido, não traduz, como sublinha Gorender, a idéia de uma invenção arbitrária. Foi, ao contrário, a interação de fatores sócio-econômicos que configurou as novas características produtivas no Brasil. De um lado, houve a repressão do Estado português à ascendente burguesia mercantil, confundida na perseguição anti-semita e na defesa dos valores da nobreza portuguesa. De outro, houve o condicionamento estrutural das relações de produção em Portugal, ainda feudais, com grande número de trabalhadores associados à terra - o que não os dispunha, por isso, como assalariados ou força de trabalho para a colonização. Além disso, havia também o condicionamento circunstancial da absorção de recursos humanos com a expansão ultramarina, por meio da renovação do estatuto da escravidão, existente de forma residual na sociedade portuguesa de então ${ }^{214}$.

A tese de um modo de produção particular no Brasil Colônia, baseado na escravidão, é também defendida por Ciro Flamarion Cardoso. Para o autor, compreender o escravismo colonial envolvia entendê-lo como uma unidade de estruturas internas e externas, que dava à colônia brasileira as definidas feições de uma sociedade em si, em oposição a um anexo mercantil ${ }^{215}$. Segundo João Fragoso, tal modelo teve como traços essenciais a interdependência entre lógica do sistema e a lógica mercantilista, a baixa produtividade das forças produtivas - pelo uso extensivo

\footnotetext{
${ }^{214}$ GORENDER, Jacob. O escravismo colonial. São Paulo: Fundação Perseu Abramo, 2016. p. 54, 121-125.

${ }^{215}$ CARDOSO, Ciro Flamarion. A Afro-América: a escravidão no Novo Mundo. São Paulo: Brasiliense, 1982. p. 79.
} 
dos recursos e da mão-de-obra - e o tráfico de escravos como principal mecanismo de reprodução ${ }^{216}$.

Modo de produção ou não, o Brasil Colônia sustentava-se no elemento da não reprodução da força de trabalho, cujas implicações estavam em todos os aspectos do constructo social que começava a se definir. Era em torno dessa questão que a elite de fazendeiros e traficantes se constituiu. Também foi ela que deu os contornos cotidianos mais absurdos e perversos da ordem escravocrata, tendo, inclusive, reflexo sobre os trabalhadores livres da época e sobre a realidade do Brasil contemporâneo, na forma do racismo, declarado ou arraigado no comportamento coletivo. Foi, finalmente, o componente que pode explicar o característico desenvolvimento colonial em ciclos, de grandes inversões de capital, seguidas de exaustão e completo abandono.

Segundo João Fragoso e Manolo Florentino, a continuidade de uma elite aristocrática na metrópole portuguesa, cujo projeto era a manutenção de sua ordem arcaica, impediu o desenvolvimento de objetivos burgueses em Portugal e abriu espaço para que segmentos sociais na Colônia assumissem atividades importantes no seu funcionamento. Parte dessa classe colonial se encarregava da produção agrícola mediante emprego de mão de obra escrava, cuja necessidade de constante reposição era suprida por um grupo hierárquico superior, os mercadores e traficantes do comércio inter-atlântico ${ }^{217}$.

Para os autores, essa composição não ameaçava os interesses metropolitanos e, ao contrário, contribuía para sua persistência como aristocracia feudal, bancada pelo excedente extraído da Colônia. A elite colonial, por sua vez, mantinha-se, com esse pacto exploratório, graças ao aproveitamento de recursos elasticamente

\footnotetext{
${ }^{216}$ FRAGOSO, João Ribeiro. Modelos explicativos da economia escravista no Brasil. In: CARDOSO, Ciro Flamarion. Escravidão e abolição no Brasil: novas perspectivas. Rio de Janeiro: Zahar, 1988. p. 21-22. ${ }^{217}$ FRAGOSO, João. FLORENTINO, Manolo. O arcaísmo como projeto. Rio de Janeiro: Civilização Brasileira, 2001. p. 225-226.
} 
disponíveis: terras e mão de obra em regime de trabalho forçado (importa dizer, recursos sacados e não reproduzidos) ${ }^{218}$.

Nas palavras de Ilmar Mattos, essa combinação de forças internas e externas formava uma região, cuja delimitação espaço-temporal se estabelecia por relações sociais, e não por simples divisas territoriais. Em sua analogia, a Metrópole e a Colônia eram faces de uma mesma moeda - a "moeda colonial" -, que articulava colonizadores, colonos e colonizados (trabalhadores escravos e livres) sob um mesmo princípio de reprodução social. Princípio de imperativos tão marcantes a ponto de implicar uma "recunhagem" (restauração do princípio) na crise do Antigo Sistema Colonial e que, assim, em novos termos, perpetuou-se ao longo do século $\mathrm{XIX}^{219}$.

À idéia de "recunhagem" retorna-se a seguir, antes cabe explicitar o significado aterrador desse princípio na vida da Colônia. Na base de todas as dimensões do diaa-dia da Colônia e da escravidão estava a absoluta não preocupação com a reprodução dos trabalhadores. A infância relegada e diminuída, os entraves à constituição de famílias, as acomodações precárias e desumanas, o trabalho insuportável, a subnutrição, as doenças decorrentes, a falta de cuidados e os castigos são as visíveis e inegáveis condições da completa incompatibilidade da escravidão com um regime de reprodução ampliada auto-sustentada, e, por extensão, com a absurda, e naturalmente inviável, idéia da reprodução de pessoas em cativeiro.

Certamente, a imagem mais destacada e terrível da escravidão eram os castigos. De acordo com Keila Grinberg, a legislação do período colonial sobre a questão dos castigos deixava aos senhores a definição das penas e de sua severidade, que freqüentemente levava a vítima à morte. Seu intuito era coibir atos de rebeldia e resistência, mas, como se isso já não era ir longe demais, relatos da época mostram que os julgamentos e punições eram arbitrários e exagerados. Quando havia alguma recomendação da Coroa no sentido de amenizar os castigos - de tão intensos

\footnotetext{
218 Ibidem.

${ }^{219}$ MATTOS, Ilmar Rohloff. O tempo Saquarema. São Paulo: Hucitec, 1987. p. 24-31.
} 
e comuns que eram -, essas tinham antes a preocupação com a ordem pública do que com os trabalhadores ${ }^{220}$.

A mortalidade era parte desse sistema, que não podia crescer naturalmente. Ao lado dos mecanismos brutais que a empreendiam ativamente - os castigos -, havia os fatores inerentes de todo o processo e que atingiam principalmente a infância. Uma vez que o crescimento vegetativo não importava na dinâmica colonial, não havia espaço nem valor para as crianças filhas de escravos.

Segundo Marília Ariza, a má alimentação, os maus tratos e o trabalho pesado faziam com que a gestação das mães escravas fosse muito difícil, refletindo no alto índice de mortalidade de recém-nascidos. Além disso, as crianças que sobreviviam eram encaradas como custos e eram doadas e quase sempre separadas de suas mães, que imediatamente, após o parto, voltavam ao trabalho. Muito cedo, mesmo muito antes da adolescência, essas crianças passavam a trabalhar como adultos, o que não lhes deixava qualquer possibilidade de receber os cuidados da infância ${ }^{221}$.

As doenças eram outra grande causa da mortalidade, potencializadas pela conjuntura da escravidão. Conforme Tânia Salgado Pimenta, as doenças que mais afetavam os trabalhadores escravos eram a tuberculose, o sarampo, a coqueluche, a varíola e as verminoses, todas agravadas pela deficiência nutricional, pelo exagero do trabalho, pela insalubridade das senzalas e pelos castigos. Se todos eram suscetíveis a essas doenças, a comparação das estatísticas pode ilustrar as condições a que a força de trabalho estava submetida, como, já no Império, mostra uma epidemia de cólera 1855 no Rio de Janeiro, que matou mais trabalhadores escravos do que a outra parcela da população 222 .

\footnotetext{
${ }^{220}$ GRINBERG, Keila. Castigos físicos e legislação. In: SCHWARCZ, Lília Moritz; GOMES, Flávio dos Santos $(\mathrm{Org}$ ). . Dicionário da escravidão e liberdade. São Paulo: Companhia das Letras, 2018.

${ }^{221}$ ARIZA, Marília B. A. Crianças e Ventre Livre. In: SCHWARCZ, Lília Moritz; GOMES, Flávio dos Santos (Org,). Dicionário da escravidão e liberdade. São Paulo: Companhia das Letras, 2018.

222 PIMENTA, Tânia Salgado. Doenças. In: SCHWARCZ, Lília Moritz; GOMES, Flávio dos Santos (Org,). Dicionário da escravidão e liberdade. São Paulo: Companhia das Letras, 2018.
} 
Todo o princípio da não reprodução envolvia também a população de trabalhadores livres, obviamente em condições muito distintas. Gilberto Freyre, por exemplo, em suas passagens bizarras de Casa-Grande e Senzala, considera "bem alimentados" os trabalhadores escravos em comparação aos trabalhadores livres, em subalimentação crônica ${ }^{223}$.

Maria Sylvia de Carvalho Franco, argumenta que a população de trabalhadores livres estava à margem da sociedade escravocrata. Se encontravam a possibilidade de subsistência na ociosidade das terras do latifúndio, como uma espécie de campesinato, isso acontecia como que por um acidente da produção mercantil e escravista, que os deixava como uma classe "sem razão de ser". Essa subsistência era tanto uma extraordinariedade do sistema que era encarada como um favor pessoal, por ambas as partes, característica do mandonismo que estruturava as relações sociais $^{224}$.

A essa categoria da população Caio Prado se refere como uma "parcela inorgânica da sociedade". Todos aqueles além do sistema escravista e da grande lavoura não tinham qualquer perspectiva, aglutinavam-se em torno do senhorio como uma clientela em improviso, cujos laços sociais e de responsabilidade se rompiam constantemente com a instabilidade da economia, que em cada crise os deixava desamparados, desenraizados e sem base de subsistência ${ }^{225}$.

O favor não encontrava sentido diretamente no substrato material da colônia. Quando as crises o faziam valer - faziam valer a realidade da não reprodução -, o instituto do favor imediatamente se dissolvia, dando lugar ao desabrigo social e potencializando a força e o significado do mandonismo.

A produção colonial, portanto, estava fundada em trabalho não reproduzido e que, por isso, precisava ser constantemente reincorporado na forma da escravidão.

\footnotetext{
${ }^{223}$ FREYRE, Gilberto. Casa-Grande e senzala. São Paulo: Global, 2003. p. 95-96.

${ }^{224}$ CARVALHO FRANCO, Maria Sylvia. Homens livres na ordem escravocrata. São Paulo: UNESP, 1997. p. 14-15;94-101; 153.

${ }^{225}$ PRADO, Caio Jr. Formação do Brasil contemporâneo. São Paulo: Companhia das Letras, 2013. p. 31015.
} 
Com efeito, antes de 1850, o alto índice de mortalidade fez com a população de trabalhadores escravos, especificamente, apresentasse sempre razões negativas de crescimento vegetativo, impondo o tráfico inter-atlântico como o fator de sua expansão na colônia ${ }^{226}$.

Como conseqüência, o escravo era necessariamente o trabalhador reproduzido fora do sistema, por outra sociedade. Ademais, no caso do projeto colonial e mercantilista português, estava associado aos negócios e aos interesses estabelecidos no Atlântico Sul e na costa africana.

Como observa Alberto Costa e Silva, o escravo era sempre "o outro", o estrangeiro. Se no início das expansões ultramarinas essa alteridade significava qualquer sociedade alheia à Europa ocidental, os negócios portugueses no Atlântico fizeram com que essa ideologia fosse reorientada a sua conveniência. No início da colonização, escravos negros não eram a maioria entre canários, mouros, turcos, armênios, eslavos e até indianos e chineses. No entanto, com a expansão do tráfico de pessoas na costa africana, a partir do final do século XVI a escravidão passou a ser identificada com uma questão racial, socialmente construída ${ }^{227}$.

Isso implicou a modificação - e reiteração por séculos - da imagem que os povos africanos tinham no imaginário europeu. As representações positivas vigentes durante a idade média, como a da Rainha de Sabá, do Rei mago Baltazar e de Preste João - lendário rei africano, cujo reino conduzido com extrema sabedoria e bondade era o objetivo da busca que justificava publicamente a expansão ultramarina do Estado português -, foram substituídas por acepções negativas e assustadoras. Desconsideravam propositalmente a sofisticação e o poder dos reinos africanos, aos quais os negócios estavam sempre sujeitos e cujas cidades equiparavam-se em tamanho e organização às cidades européias e americanas ${ }^{228}$.

\footnotetext{
${ }^{226}$ ARIZA, Marília B. A. Op. Cit, 2018.

${ }^{227}$ COSTA E SILVA, Alberto. A manilha e o libambo. Rio de Janeiro: Nova Fronteira, 2011. p. 774-810.

${ }^{228}$ Ibidem.
} 
De tal modo, legitimou-se a materialidade da escravidão e da não reprodução da força de trabalho com a idéia de discriminação racial, que perdura estupidamente até a atualidade. Fazia parte do mecanismo de manutenção da produção colonial, que, em grande medida, se vinculava aos interesses de traficantes que mantinham atividades comerciais no Atlântico. Tais atividades eram cada vez mais desempenhadas por uma elite de brasileiros, como é o caso do rico comerciante Francisco Félix de Sousa e de tantos outros que se estabeleceram na África, entre os séculos XVIII e XIX, como grandes traficantes de escravos, conservando agências, por laços familiares, em ambas as margens do Atlântico ${ }^{229}$.

Foi essa estrutura que se sobrepôs à escravidão de trabalhadores indígenas, mas que não a impediu de existir organicamente na sociedade colonial. Segundo Alencastro, a legislação que proibia o cativeiro indígena não tinha efeito na prática, especialmente nas capitanias do sul. Se essas não dispunham de proeminência no tráfico, era porque sofriam com questões conjunturais e, sobretudo, por suas elites estarem excluídas dos negócios do Atlântico ${ }^{230}$.

Assim, sem vínculo com uma base produtiva que se perpetuava por meio de um aparelho interno e que, por isso, não se enraizava, o processo econômico da Colônia caracterizou-se por um desenvolvimento em ciclos. Uma vez impedido o aprofundamento das forças produtivas, a exaustão da exploração extensiva dos recursos coloniais, aos ventos do mercado mundial, deslocava constantemente o eixo das atividades para novos produtos e novas áreas, mas implicava também o abandono das estruturas anteriormente existentes. Assim, em detrimento de um verdadeiro processo de acumulação, a economia colonial desenvolvia-se, como observa Caio Prado, aos “arrancos”, em um movimento anda-e-pára ${ }^{231}$.

Uma interpretação semelhante é apresentada por Celso Furtado a respeito desse movimento circular, que voltava sempre à estaca zero. Para tal autor, desde sua

\footnotetext{
${ }^{229}$ Idem. Um rio chamado Atlântico. Rio de Janeiro: Nova Fronteira, 2011. p. 65-70.

${ }^{230}$ ALENCASTRO, Luiz Felipe. Op. Cit., 2000. p. 117-127.

${ }^{231}$ PRADO, Caio Jr. Op. Cit. p. $125-127$.
} 
fundação como colônia, o Brasil vivenciou três séculos e meio de estagnação econômica, com ciclos de ascensão e interrupção de seu desenvolvimento ${ }^{232}$.

Tal dinâmica, de um lado, induzia a ocupação do território nacional, de outro, fragmentava-o em regiões, que praticamente não guardavam qualquer interdependência. Nesse sentindo, Klara Káiser Mori sustenta a tese de que a formação do espaço nacional brasileiro, que começava a emergir desse processo, nada tinha de uma acumulação desimpedida, que levaria à superação das barreiras naturais, à unificação política e administrativa, assim como, à completa integração nacional. Ao contrário, era particularidade nutrida pela constante reimposição das fronteiras administrativas, da qual, por sua vez, resulta a fragmentação e o isolamento espaciais característicos dos tempos coloniais ${ }^{233}$.

Especificamente no plano ideológico, continua a autora, as visões edênicas que permearam as descrições coloniais e do descobrimento das terras americanas constituíram o fundo justificativo para a não construção, e não reprodução, do território colonial. Atravessando as vicissitudes sociais e políticas dos séculos XIX e XX, essa concepção manteve-se no ideário nacional como a qualidade "jovem" - preservável do território nacional, que lega sempre ao futuro sua construção e encobre a dinâmica material que o explora extensivamente no presente, preterindo sua apropriação dentro de um contexto de reprodução ampliada ${ }^{234}$.

Mesmo as mais recentes iniciativas de organização espacial no Brasil, como a Política de Nacional de Ordenamento Territorial (PNOT), constituíram tentativas hesitantes e frágeis frente à prática estatal estabelecida. Para Cintia Alves, a diversidade do teor propositivo da PNOT, contraposta à invariabilidade da ação

\footnotetext{
${ }^{232}$ FURTADO, Celso. Formação econômica do Brasil. São Paulo: Companhia das Letras, 2007.

${ }^{233}$ MORI, Klára Kaiser. Brasil: urbanização e fronteiras. Tese de Doutoramento. Universidade de São Paulo, Faculdade de Arquitetura e urbanismo. 1996. p. 8 a 9.

${ }^{234}$ Idem. A ideologia na constituição do espaço brasileiro. In DEÁK, Csaba; SCHIFFER, Sueli (Org.). 0 processo de urbanização no brasil. São Paulo: Edusp, 2010. p. 51-54.
} 
governamental na estruturação do espaço brasileiro, marcou um complexo processo de elaboração que acabou por inviabilizar a continuação do próprio ${ }^{235}$.

A verdade é que na crise do sistema colonial e na passagem de colônia à nação, algo essencial de todo esse processo permaneceu no desenvolvimento do Brasil. Uma das mais célebres elaborações dessa suspeita é o que Caio Prado chamou de "o sentido colonial da evolução do Brasil". Sentido gravado na história do País pelo modo como a própria sociedade e a economia brasileiras foram organizadas desde os tempos coloniais, voltada ao fornecimento de bens primários ao mercado internacional ${ }^{236}$.

Para Emília Viotti, a liderança do movimento de independência, guiado por classes interessadas na manutenção da estrutura colonial, determinou a continuidade da economia fundamentada na exportação de produtos tropicais e no já decadente trabalho escravo. O objetivo da reformulação política por que passava o Brasil no início do século XIX, portanto, consistia em reorganizar o Estado sem alterar o arranjo social e a base econômica da nação ${ }^{237}$.

A "moeda colonial" a que se refere Ilmar Mattos precisou, então, ser recunhada. E isso significava uma escolha, a restauração auto-determinada de um princípio de reprodução social. O lado colonial passaria a ser o Brasil independente, o da metrópole seria ocupado pelas potenciais capitalistas européias. Contudo, o exercício do novo monopólio metropolitano embargava o circuito de suprimento de mão-de-obra escrava, por isso, o Estado brasileiro procurou contornar essa problemática com uma política de terras e de imigração ${ }^{238}$.

Para Csaba Deák, esse é o momento de constituição de uma acumulação entravada no Brasil. Em essência, acumulação entravada “é uma reprodução ampliada,

\footnotetext{
${ }^{235}$ ALVES, Cintia de Souza. A tentativa de uma política de ordenamento territorial no Brasil. Tese de Doutoramento. Universidade de São Paulo, Faculdade de Arquitetura e urbanismo. 2017.

${ }^{236}$ PRADO, Caio Jr. Op. Cit., 2013. p. 10.

${ }^{237}$ COSTA, Emília Viotti da. Introdução ao estudo da emancipação política do Brasil. In: MOTA, Carlos Guilherme (Org.). Brasil em perspectiva. São Paulo: Difel, 1977. p. 122.

${ }^{238}$ MATTOS, Ilmar Rohloff. Op. Cit., 1987. p. 80-90;98.
} 
em que parte do excedente produzido anualmente é incorporado à produção acumulado -, enquanto outra parte é expatriada e fica assim perdido para o processo de acumulação"239. Tal funcionamento foi engendrado em meio à ruptura do sistema colonial e à internalização do aparato estatal no Brasil, o que definiu, portanto, uma formação social autônoma - autodeterminada -, ainda que conservados certos aspectos da organização produtiva precedente - de natureza colonial ${ }^{240}$

Portanto, se, por um lado, o Brasil adentrava uma nova era, lançando-se ao capitalismo, por outro, restaurava a base material originária da colônia. Recorrendo-se novamente às palavras de Caio Prado, o Brasil contemporâneo é: "O passado colonial que se balanceia e encerra com século XVIII, mais as transformações que se sucederam no decorrer do centênio posterior a este e no atual”241. Por mais complexo que esse processo social possa ser, sua essência reside na não reprodução da força de trabalho, ou na sua extraterritorialidade, que, como sustenta Alencastro, mesmo após a suspensão do tráfico em 1850, subsistirá na forma de importação da força de trabalho de imigrantes ${ }^{242}$.

\footnotetext{
${ }^{239}$ DEÁK, Csaba. Verbete: Acumulação Entravada. Disponível em:

http://www.usp.br/fau/docentes/depprojeto/c_deak/CD/4verb/acum-ent/index.html. Acesso em: 05/02/2020.

${ }^{240}$ Idem. Acumulação entravada no Brasil e a crise dos anos 1980. In DEÁK, Csaba; SCHIFFER, Sueli (Org.). $O$ processo de urbanização no brasil. São Paulo: Edusp, 2010. p. 23.

${ }^{241}$ PRADO, Caio Jr. Op. Cit. 2013. p. 10.

${ }^{242}$ ALENCASTRO, Luiz Felipe. Op. Cit., 2000. p. 354.
} 


\subsection{Transformações institucionais e perpetuidade material}

Se há algo que chama a atenção na história brasileira após a Independência é sua instabilidade política e institucional. Independência, reinados, Regência, República, golpes, revoltas desestabilizadoras e até uma guerra internacional, tudo o que ocorreu em menos de cem anos durante o século XIX.

Ainda assim, persiste a compreensão que pouco dessas transformações significaram uma mudança real, material. Só em 1888 a escravidão foi abolida, e as importações de mão-de-obra, as condições e regimes de trabalho e, enfim, a baixíssima preocupação com a reprodução dos trabalhadores continuou inalterada por décadas. Além disso, defende-se adiante, o princípio dessas ações pôde ser restaurado no assalariamento e na urbanização do século XX.

Para vários autores, o mercado de trabalho no Brasil - isto é, o esqueleto das relações salariais típicas do capitalismo -, só começou a tomar feições efetivamente depois de 1930. Até então, mesmo depois das reformas de 1850, as relações cotidianas continuaram pautadas pelo velho mecanismo que tornava a subsistência dos trabalhadores um improviso nos interstícios e oportunidades da grande economia, sempre ligado, por desdobramento, aos favores e ao clientelismo.

No fundo, essa é a base do caráter atipicamente burguês da sociedade brasileira. Observa Florestan Fernandes que a lógica de mercado - o princípio da generalização da forma-mercadoria e inteiramente vinculada ao assalariamento - não possui preeminência nas relações de produção no Brasil. Em conseqüência, a "função classificadora do Mercado" - que concretiza as instituições e os estratos sociais burgueses - esvazia-se de efetividade e cede lugar ao super-privilegiamento de determinados grupos que ostentam apenas um aspecto burguês, mas que, na 
realidade, compõem um arranjo de classes consideravelmente distinto, designada aqui sociedade de elite, diferente de burguesa ${ }^{243}$.

Nesse contexto, sustentar um aspecto burguês, buscando uma identificação com as idéias e os modos da elite européia e mundial, colocou sempre a sociedade e a elite brasileira em apuros. $\mathrm{Na}$ raiz de todas as incongruências ideológicas da sociedade brasileira estava a impropriedade dos ideais e valores burgueses no Brasil, trazidos da Europa em pleno e desimpedido estágio extensivo de acumulação capitalista para a economia escravista e semi-escravista do País.

Se lá, onde foram concebidas, essas idéias correspondiam a um processo social e serviam contra as instituições do Antigo Regime, aqui nada representavam. Constituíam o que Roberto Schwarz chamou de idéias fora do lugar ${ }^{244}$, ou o que Emir Sader notou como uma inversão do liberalismo Europeu, ideologia da burguesia ascendente ${ }^{245}$.

Originadas em uma realidade muito diferente das circunstâncias locais, as idéias liberais no Brasil levavam a sociedade a inevitáveis impasses. Embora tais concepções fossem de materialização impossível diante das condições de reprodução da ordem social brasileira, eram também indispensáveis a ela, pois além de necessárias à organização do Estado independente, eram uma prova de modernidade e distinção a que submetia a "regra do relevo social"246.

Para Schwarz, na verdade, não poderia existir sequer uma alternativa a essa situação. Mesmo com todas as complicações decorrentes da incorporação do modelo liberal, não havia o impulso de rejeitá-lo, sob a pena de isso significar um retrocesso, tampouco uma força nacional capaz de promover qualquer tipo de invenção

\footnotetext{
${ }^{243}$ FERNANDES, Florestan. Capitalismo dependente e classes sociais na América Latina. São Paulo: Zahar, 1973. p. 69-70.

244 SCHWARZ, Roberto. Ao vencedor as batatas. São Paulo: Duas Cidades/Editora 34, 2008. p. 17-19.

${ }^{245}$ SADER, Emir. Constituinte, democracia e poder. In: Sader, Emir (ORG.). Constituinte e democracia no Brasil hoje. São Paulo: Brasiliense, 1985. p. 129.

${ }^{246}$ Ibidem. p. 19;26.
} 
doutrinária ${ }^{247}$. De tal modo, enquanto a base material no Brasil atravessou inalterada a Independência, o Império e a República, no âmbito ideológico foram seguidos os mesmas passos do desenvolvimento europeu - um padrão, vale dizer, que se repetiria no século $X X^{248}$.

Parafraseando Eric Hobsbawm, Guilherme Velho compara o desenvolvimento inglês ao brasileiro. Enquanto lá a transformação social aconteceria subjacente à permanência das velhas instituições, no Brasil, as novas instituições seriam sobrepostas à imutável realidade social e econômica. "Trocam-se os rótulos, mas se mantêm as garrafas" ${ }^{249}$.

Para Emília Viotti, o liberalismo e o próprio nacionalismo não se assentaram na conjuntura brasileira, perdendo, de tal modo, seu verdadeiro sentido. Mesmo os movimentos pela Independência caracterizavam-se por certa esterilidade ideológica, pois além do fato de seus valores liberais não atingirem grande parte da população, isolada pelo analfabetismo, o maior impedimento para a total realização de seu significado sobrevinha da inconciliável essência do liberalismo com a situação brasileira. Essa reorganização política tratava-se, portanto, de um amoldamento do Estado sem uma respectiva alteração de sua base econômica e social ${ }^{250}$.

Se assim compreendida, a instabilidade política e institucional no Brasil refletiu nada mais do que seu constante desajuste em relação à ideologia burguesa. Traduziu também sua incapacidade em superá-la diante do restabelecimento de sua base material emersa da Colônia. Por fim e sobretudo, nunca representou o embate entre qualquer tipo de forças ou projetos políticos em torno de sua transformação.

De acordo com Viotti, republicanos ou monarquistas, liberais ou conservadores, quase todos os membros da elite no Brasil tinham em comum a atividade agrícola ou

\footnotetext{
${ }^{247}$ SCHWARZ, Roberto. Op. Cit, 2008. p. 17.

248 Ibidem. p. $21 ; 25$.

${ }^{249}$ VELHO, Otávio Guilherme. Capitalismo autoritário e campesinato. Rio de Janeiro/São Paulo: Difel, 1979. p. 124-127

${ }^{250}$ COSTA, Emília Viotti Da. Introdução ao estudo da emancipação política do Brasil. In: Brasil em perspectiva. Mota, Carlos Guilherme (Org.). São Paulo: Difel, 1977. p. 76; 90-94; 122.
} 
comercial voltada ao mercado internacional. Discutia-se a respeito de formas de governo, de traçados viários e sobre posturas ideologias, mas havia sempre a tendência a um acordo em relação à política trabalhista, aduaneira e de crédito, de modo que os rumos do desenvolvimento nacional eram compactuados sem grandes conflitos $^{251}$.

Em 1850, frente à conjuntura mundial, um grupo de leis preparou institucionalmente o Brasil para a transição ao trabalho livre. Trata-se especialmente da Lei de Terras e da Lei Eusébio de Queirós. A primeira, concebida nos moldes do chamado Sistema Wakefield, instituía a compra como única forma de acesso a terra, privando a maior parte da população da subsistência agrícola e induzido, assim, a formação da força de trabalho assalariada. A segunda extinguia, de fato, o tráfico interatlântico de escravos e eliminaria a escravidão da concorrência com o trabalho assalariado, abrindo, juntamente com a Lei de Terras, o caminho para a modificação das relações de produção ${ }^{252}$.

A mudança, contudo, foi encarada como uma ameaça à economia e à ordem social existente, montada assim, sobre a escravidão e a importação de força de trabalho, desde o Descobrimento. Não tardaram, portanto, soluções que evitavam dar efeito à transformação.

Houve, a princípio, como explica Alexandre de Freitas Barbosa, a tentativa de manter a escravidão por mecanismos internos, seja pelo crescimento natural ou pelo tráfico inter-regional. No primeiro caso, as taxas negativas de crescimento vegetativo mostraram ser inviável o aumento da população escrava, que de 1854 a 1872 apresentou um índice de $-0,4 \%$. Os deslocamentos internos, por sua vez, apesar dos números significativos - cerca de 200 mil trabalhadores escravos foram transladados

\footnotetext{
${ }^{251}$ Idem. Da Monarquia à República. 1998. São Paulo: Editora UNESP, 2007. p. 360-363.

252 DEÁK, Csaba. Falas e façanhas. In DEÁK, Csaba; SCHIFFER, Sueli (Org.). O processo de urbanização no brasil. São Paulo: Edusp, 2010. p. 15 e 16.
} 
de uma província à outra no período acima -, geraram problemas políticos e 1885 foram definitivamente proibidos ${ }^{253}$.

Paralelamente, políticas de imigração de trabalhadores livres eram endereçadas à questão da "falta de braços". Se até 1850 a imigração de trabalhadores livres era conteúdo de debates vagos, anotam Luiz Felipe de Alencastro e Maria Luiza Renaux, após a extinção do tráfico inter-atlântico de trabalhadores escravos a pressão dos fazendeiros para o estabelecimento de uma política de imigração subvencionada tomou as discussões da época ${ }^{254}$.

Os projetos de imigração se materializaram e seus números são consideravelmente expressivos. Entre 1550 e 1850, em torno de 4 milhões de pessoas foram trazidas à força da África, ao passo que, entre 1850 e 1950, 5 milhões de europeus, levantinos e asiáticos imigraram ao Brasil ${ }^{255}$. Nas palavras de Luiz Felipe de Alencastro, o "defeito metabólico" que caracterizava o desenvolvimento da Colônia, que desterritorializava a reprodução da força de trabalho com o tráfico de escravos, foi reciclado no "tráfico de imigrantes". A "xenofagia" da economia brasileira continuaria em moldes muito semelhantes ${ }^{256}$.

Esse é também o entendimento de Caio Prado. A imigração, na sua compreensão, constituiu um recrutamento forçado de trabalhadores e guardava muitas semelhanças com o tráfico de trabalhadores escravos, o que, aliás, visava a substituir. Era uma continuação, sob nova forma, do velho sistema econômico e social herdado da Colônia. Um organismo mercantil voltado à produção de gêneros tropicais - o café -, apoiado na exploração de trabalhadores por quem a grande lavoura pouco tinha o respeito de sua condição de trabalhadores livres. A mesma lavoura que muito menos

\footnotetext{
253 BARBOSA, Alexandre de Freitas. A formação do mercado de trabalho no Brasil. São Paulo: Alameda, 2008. p. 94-97.

${ }^{254}$ ALENCASTRO, Luiz Felipe; RENAUX, Maria Luiza. Caras e modos dos migrantes e imigrantes. In: ALENCASTRO, Luiz Felipe (Org.). História da vida privada no Brasil. Vol 2. São Paulo: Companhia das letras, 1997. p. 293.

255 Ibidem. p 310-314.

${ }^{256}$ ALENCASTRO, Luiz Felipe. A pré-Revolução de 30. Novos Estudos Cebrap. N. 18, 17-21. São Paulo: Cebrap, 1987. p. 17-18.
} 
apresentava um projeto de assalariamento e inclusão à dinâmica econômica para a população emersa da escravidão. A imigração, como ação governamental, adentrou o século XX e foi oficialmente extinta em 1927. Nas palavras do autor: "O tráfico de escravos foi abolido em 1850. O tráfico de imigrantes encerrou-se em 1927"257.

Originários de uma condição proletária ou camponesa, os imigrantes seriam reduzidos na lavoura brasileira a um estado de escravidão não formal. Ou seja, submetidos ao mesmo princípio de não reprodução que permeou toda história econômica do Brasil. Em certas ocasiões, coabitavam com trabalhadores escravos as senzalas e partilhavam com eles as duras condições de trabalho, extensivas até mesmo às crianças ${ }^{258}$.

$\mathrm{Na}$ maior parte das vezes, entretanto, os contratos de trabalho consistiam em uma espécie deturpada de assalariamento, associada à terra. Esses contratos dividiam-se em basicamente três tipos. A primeira e antecessora no tempo foram os projetos de colonização. Tratava-se da ocupação de terras cedidas pelo Estado para o estabelecimento de núcleos camponeses estrangeiros. Como isso não configurava uma oferta de trabalho para a grande lavoura, seus resultados foram inexpressivos e seriam substituídos por um segundo regime de contrato: a parceria ${ }^{259}$.

A parceria se caracterizava pelo custeio da viagem dos imigrantes pelos fazendeiros e sua cobrança em forma de dívida e trabalho obrigatório na lavoura até que esse valor fosse saldado. Parte da subsistência dos trabalhadores estava associada ao cultivo de pequenos lotes de terra concedidos pelo empregador. Além disso, o regime era composto por fatores extra-econômicos. Manipulação das taxas de juros, multas arbitrárias, restrição à liberdade de movimento e a direitos básicos, prisão e até espancamentos faziam parte do cotidiano do contrato de parceria. Ao fim

\footnotetext{
${ }^{257}$ PRADO, Caio Jr. A imigração brasileira no passado e no futuro. In: A evolução política do Brasil e outros estudos. São Paulo: Editora brasiliense, 1953. p. 261-265.

${ }^{258}$ ALENCASTRO, Luiz Felipe; RENAUX, Maria Luiza. Op. Cit., 1997.

${ }^{259}$ BARBOSA, Alexandre de Freitas. Op. Cit., 2008. p. 98-116.
} 
de quatro ou cinco anos, os trabalhadores conseguiam sua libertação e um novo ciclo, com novos trabalhadores e novos desembolsos de capitais, se iniciava ${ }^{260}$.

A resistência dos trabalhadores e a pressão de seus governos fizeram com que tal regime de trabalho fosse logo modificado. Isso daria origem ao chamado sistema de colonato, em que parte da subsistência continuaria atrelada ao cultivo de parcelas de roça. Os trabalhadores também recebiam um salário fixo juntamente com a produção entregue. Apesar disso, as condições de trabalho não melhoraram. Para Barbosa, essas etapas não constituíram a seqüência lógica no estabelecimento de um mercado de trabalho no Brasil, e estavam longe no processo de produção e reprodução interna da força de trabalho ${ }^{261}$.

Tais medidas visavam, sobretudo, a um ajuste do decadente instituto da escravidão. Como comenta Boris Fausto, essas formas de assalariamento destinavam-se a "estabilizar" as relações de trabalho que se desestruturavam com o fim da escravidão ${ }^{262}$, aproximando os fundamentos da emergente sociedade brasileira ao que havia sido praticado até então.

Dentro dessa realidade, formas ainda mais específicas desse tipo de assalariamento degenerado passaram a existência e se perpetuaram no tempo. Caio Prado cita como exemplo dessas reminiscências o sistema de "barracão" fornecimento de gêneros alimentícios, geralmente a preços extorsivos, a trabalhadores em acampamentos isolados (sistema ainda corrente nos dias atuais no norte do País, nos piaçabais) - e o "cambão" - prestação de trabalho gratuito em troca do uso da terra $^{263}$.

Em sua essência estava o desvirtuado regime de terras que se conformou no Brasil a partir da lei que, paradoxalmente, tinha o intuito de viabilizar o trabalho assalariado. Para José de Souza Martins, os sistemas de colonato e parceria

\footnotetext{
${ }^{260}$ Ibidem.

${ }^{261}$ Ibidem

${ }^{262}$ FAUSTO, Boris. História Concisa do Brasil. São Paulo: Edusp, 2008. p. 98.

263 PRADO, Caio Jr. A revolução brasileira. São Paulo: Brasilense, 1966. p. 54-57.
} 
instituíam uma relação de trabalho não muito diversa da escravidão, sendo a terra, pela possibilidade do eventual cultivo de subsistência em parcelas impróprias à grande lavoura, um instrumento de coerção. É somente depois das primeiras décadas do século XX que a produção de subsistência e de gêneros alimentícios se tornará independente das grandes propriedades ${ }^{264}$.

Esse regime de terras generalizou-se em consonância à perpetuidade das relações de produção e em detrimento dos mecanismos tipicamente capitalistas de reprodução da força de trabalho. Conforme Luisa Battaglia, a coleção de normas e instruções derivadas da Lei de Terras de 1850, ao invés de consolidar uma estrutura legal capaz de dar seqüência a seu propósito original - estabelecer a propriedade privada burguesa e garantir/obrigar o trabalho livre -, constituía uma série de disposições formais que tornava a matéria cada vez mais confusa e a ação estatal a seu respeito praticamente inoperante ${ }^{265}$.

Além de necessidades técnicas cruciais permanecerem sem soluções, como mapeamento e referenciamento cadastral, as próprias regras estabelecidas definiam critérios tão específicos para o reconhecimento de propriedade que a análise "caso a caso" seria imperativa. Dissolvia, assim, a função do instrumento como diretriz universal e permitia adulterações, cujos melhores exemplos seriam os artigos iniciais da Lei 601 de 1850, sobre as Terras Devolutas, e o capítulo III do correlato Decreto 1318 de $1854^{266}$.

Nessa mesma acepção cabem as observações de José Murilo de Carvalho, que considera o regime de terras no Império uma faceta da relação de ajuste e desajuste entre as idéias, valores e instituições da sociedade brasileira e sua materialidade. Desde 1835 era esboçada no Brasil a política de Terras que culminaria na Lei de 1850, em uma discussão claramente inspirada por conceitos relacionados ao

\footnotetext{
${ }^{264}$ MARTINS, José de Souza. O cativeiro da Terra. São Paulo: Contexto, 2017. p. 144-146.

${ }^{265}$ BATTAGLIA, Luisa. Cadastros e registros fundiários: a institucionalização do descontrole sobre o espaço no Brasil. Tese (Doutorado) - Faculdade de Arquitetura e Urbanismo da universidade de São Paulo. São Paulo, 1995. p. 118-119.

${ }^{266}$ Ibidem.
} 
Sistema Wakefield e a um programa de importação de mão de obra assalariada. Ainda assim a proposta não seria concretizada, tanto pela falta de recursos humanos e técnicos como, e principalmente, pela grande oposição parlamentar, o que retardou o estabelecimento de uma economia de mercado no País e enfraqueceu as bases liberais do Estado ${ }^{267}$.

No entendimento de Caio Prado, a incapacidade em regulamentar a questão fundiária representava bem o que acontecia com toda a legislação do Império: tratavase de uma tentativa insuficiente de inaugurar as instituições próprias à nova realidade da nação. Apesar da importância do assunto em um país agrícola e muito pouco ocupado, a única iniciativa que visava a alguma solução, a Lei de Terras de 1850, nunca fora efetivamente concretizada. Desse modo, pelo menos até a década de 1950, grande parte do território brasileiro foi deixada sem qualquer tipo de registro, alongando uma enorme lista de litígios acerca do reconhecimento da propriedade da terra $^{268}$.

Além disso, em muitos casos a propriedade, garantida àqueles que possuíam a terra antes da institucionalização desse direito, era usurpada de humildes sitiantes como decorrência das relações clientelistas entre fazendeiros e seus agregados. José de Souza Martins destaca que, não raramente, é possível encontrar nos Registros Paroquiais declarações de posseiros que, manipulados por barões rurais, renunciavam, em total benefício desses, seus direitos sobre os terrenos ocupados, deixando inalterado o monopólio da terra pelos latifundiários e as relações de favor que regiam a sociedade ${ }^{269}$.

Mesmo áreas que supostamente encabeçavam a renovação econômica do País não eram uma exceção a esse funcionamento. Em seu meticuloso estudo sobre a grilagem de terras em São Paulo, Paulo Coe mostra que o total descontrole sobre o

\footnotetext{
${ }^{267}$ CARVALHO, José Murilo de. A construção da ordem e Teatro de sombras. Rio de Janeiro: Civilização Brasileira, 2008. p. 331-351.

${ }^{268}$ PRADO, Caio Jr. Roteiro para a historiografia do Segundo Reinado (1840-1889). In: A evolução política do Brasil e outros estudos. São Paulo: Editora brasiliense, 1953. p. 214.

${ }^{269}$ MARTINS, José de Souza. Op. Cit, 2017. p. 195-196.
} 
tema encobria um aparato de corrupção profundamente arraigado na história da formação do território brasileiro. A incompreensão de grande parte da população e as incontáveis formas de desvio da lei atestavam a completa desvinculação desse modelo de propriedade frente à conjuntura social existente ${ }^{270}$.

O efeito prático dessa conjuntura fundiária era o impedimento da consolidação das puras relações de produção capitalistas no Brasil. Para a sociedade brasileira, entretanto, isso não era um problema - antes, uma solução -, pois seu desenvolvimento continuava aferrado a seu velho princípio de constituição, baseado na importação de força de trabalho.

Em resumo, para Alencastro, todo esse processo define o elemento de longa duração que apreende a formação do Brasil: a desterritorialização da reprodução da força de trabalho. De 1550 a 1930-40, o contingente principal de trabalhadores nasceu e cresceu fora dos limites da Colônia e do território nacional ${ }^{271}$.

O que se argumenta a seguir é que, a partir desse último período, o princípio da não reprodução será restaurado e perpetuado na acumulação extensiva, no assalariamento e na urbanização do Brasil, possibilidades latentes em sua história desde as reformas de 1850.

\footnotetext{
${ }^{270}$ COE, Paulo. São Paulo: “paraíso” dos grileiros. Sem dados de edição ou data. p. 2;123.

${ }^{271}$ ALENCASTRO, Luiz Felipe. Op. Cit., 2000. p. 354-355.
} 


\subsection{Acumulação entravada, urbanização e limites materiais}

A gênese da urbanização, do assalariamento, da acumulação extensiva e do próprio capitalismo no Brasil não é um fenômeno de meados do século $X X$, como parece sugerir seus números, que se intensificam nesse período. Esse processo tampouco marcou uma ruptura com a linhagem da reprodução social emersa da Colônia - com o sentido colonial de seu desenvolvimento.

Trata-se, antes de tudo, do arranjo material que possibilitou a continuidade dos traços peculiares da sociedade brasileira, talhados na história do País desde sua formação na Colônia. Sua exaustão, no entanto, impõe hoje uma reforma que, na verdade, significa a extinção de uma ordem social existente há quase 500 anos.

É possível dizer que o capitalismo no Brasil tem data de aniversário, mas que também cresceu ajustando-se à sociedade que Ihe deu origem. Em 1850, a Lei de Terras e a Lei de proibição do tráfico inter-atlântico de trabalhadores escravos lançou, premeditadamente, as bases das relações de produção capitalistas no Brasil| ${ }^{272}$.

De certo modo, foi quase uma "revolução do alto" - como conceitua Eric Hobsbwan com a Restauração Meiji no Japão e a Unificação Alemã dos Junkers -, exceto pelo fato de que aqui não foi uma revolução. Nos casos do Japão e da Alemanha, a sociedade lá estabelecida empreendeu grandes reformas econômicas, que representaram a completa modificação de sua base material na implantação das relações de produção capitalistas ${ }^{273}$.

O nascimento do capitalismo no Brasil, ao contrário, não exigiu a liquidação, nem muitas concessões, da base material existente. Isso porque a acumulação extensiva (regime primeiro do desenvolvimento capitalista) guarda como essência o mesmo princípio de externalidade da reprodução da força de trabalho, que aqui há muito imperava. O que antes se resolvia com a importação de mão de obra

\footnotetext{
${ }^{272}$ DEÁK, Csaba. Falas e Façanhas. In DEÁK, Csaba; SCHIFFER, Sueli (Org.). O processo de urbanização no brasil. São Paulo: Edusp, 2010. p. 15.

${ }^{273}$ HOBSBAWM, Eric. The age of capital. Londres: Abacus, 1977. p. 180-182
} 
estrangeira, passou, então, a ser resolvido com a migração interna, sem grandes conseqüências de ordem prática.

Ainda que o cotidiano da sociedade brasileira passasse de rural a urbano, em si uma grande transformação, o motor das relações sociais e o sustentáculo da dinâmica produtiva permaneciam inalterados. A alusão à frase de Lampedusa é ilustrativa: "é preciso mudar, para que tudo possa permanecer o mesmo"274.

A xenofagia a que se refere Luiz Felipe de Alencastro deu lugar à territorialização do trabalho. Em suas palavras, os trabalhadores, antes "comidos crus" - em uma condição de "infra-cidadania" -, passarão a ser "servidos cozidos". Para o autor, isso significa a internalização dos mecanismos de reprodução da força de trabalho no Brasil ${ }^{275}$.

Entretanto, defende-se aqui a tese de que isso não traduziu uma mudança. baixo nível das condições de reprodução da força de trabalho, demandado em um regime de acumulação extensiva e marcado pelo assalariamento e a migração campocidade - pela urbanização -, não apenas possibilitou a continuidade do processo de não reprodução dos trabalhadores, como também sustentou as altas taxas de excedente que permitiram a perpetuidade da velha economia de exploração e exportação de produtos de baixo valor agregado.

É nisso que se ancora, em última instância, a dialética da reprodução capitalista no Brasil, a acumulação entravada. Para Csaba Deák, a acumulação entravada é o embasamento econômico da sociedade brasileira. Tal embasamento tem origem colonial e consiste em uma dinâmica de reprodução ampliada em que parte do excedente é nela reinvestido e outra parte é expatriada, ficando, assim,

\footnotetext{
${ }^{274}$ DEÁK, Csaba. Acumulação entravada no Brasil e a crise dos anos 1980. In DEÁK, Csaba; SCHIFFER, Sueli (Org.). O processo de urbanização no brasil. São Paulo: Edusp, 2010. p. 34.

${ }^{275}$ ALENCASTRO, Luiz Felipe. A pré-Revolução de 30. Novos Estudos Cebrap. N. 18, 17-21. São Paulo: Cebrap, 1987.
} 
perdida para o processo de acumulação. Em sua definição, "a exploração colonial torna-se expatriação do excedente" ${ }^{\text {276 }}$.

Seu expediente de funcionamento são os entraves autoimpostos que impedem o pleno desenvolvimento das forças produtivas. A fragmentação política e administrativa do território nacional, as constantes barreiras levantadas ao amadurecimento industrial do País e as incansáveis campanhas contra a ação estruturadora do Estado - tão contemporâneas - são exemplos ${ }^{277}$.

A acumulação entravada, contudo, tem sua manutenção vinculada a um regime extensivo, e a exaustão desse implica a crise da acumulação entravada no Brasil. Lido nas taxas de urbanização, que representam o avanço do assalariamento e da extensão das relações de produção capitalista, o esgotamento da acumulação extensiva, alcançado no Brasil por volta dos anos 1980 e 1990, deixa um impasse à sociedade brasileira que já dura décadas: As suspensão dos entraves e o definitivo início de uma acumulação intensiva no Brasil, ou a perda de sua qualidade de reprodução ampliada ${ }^{278}$.

Em ambos os casos, não há mais espaço para o status quo. De um lado, a acumulação com a manutenção da expatriação do excedente é impossível sem as altas taxas do regime extensivo, de modo que perpetuá-la significa não acumular, não se reproduzir de maneira ampliada e, assim, fenecer como sociedade. De outro, a reforma que envolve a instauração de um regime intensivo de acumulação representa também uma revolução à ordem social brasileira ${ }^{279}$.

Baseada no aumento da produtividade do trabalho, a acumulação intensiva exige a elevação do nível das condições de reprodução da força de trabalho. Tal elevação é necessariamente provida pelo Estado, principalmente com a melhoria e a expansão de serviços e de infraestruturas urbanas. Trata-se de escopo nunca

\footnotetext{
${ }^{276}$ DEÁK, Csaba. Acumulação entravada no Brasil e a crise dos anos 1980. Op. Cit., 2010. p. 28-32.

277 Ibidem. p. 33-35.

278 Ibidem. p. 35-38.

279 Ibidem.
} 
praticado no Brasil, cuja execução contrapõe-se à estrutura das relações sociais estabelecidas - o favor, o clientelismo, o racismo - e à própria organização produtiva, pois todo o processo social sempre respondeu à não reprodução das forças produtivas, em especial, da força de trabalho ${ }^{280}$.

O que se quer relevar, de acordo com o argumento seguido até aqui, é que a reprodução da força de trabalho e sua relação com as questões urbanas são elemento chave no estudo da história brasileira. A evolução da urbanização (como abixo mostrado) e suas características no Brasil, como parte da acumulação extensiva, marcaram as precárias e improvisadas condições em que se reproduziram os trabalhadores brasileiros no século $\mathrm{XX}$, em correspondência ao princípio herdado da colônia e que os relegava.

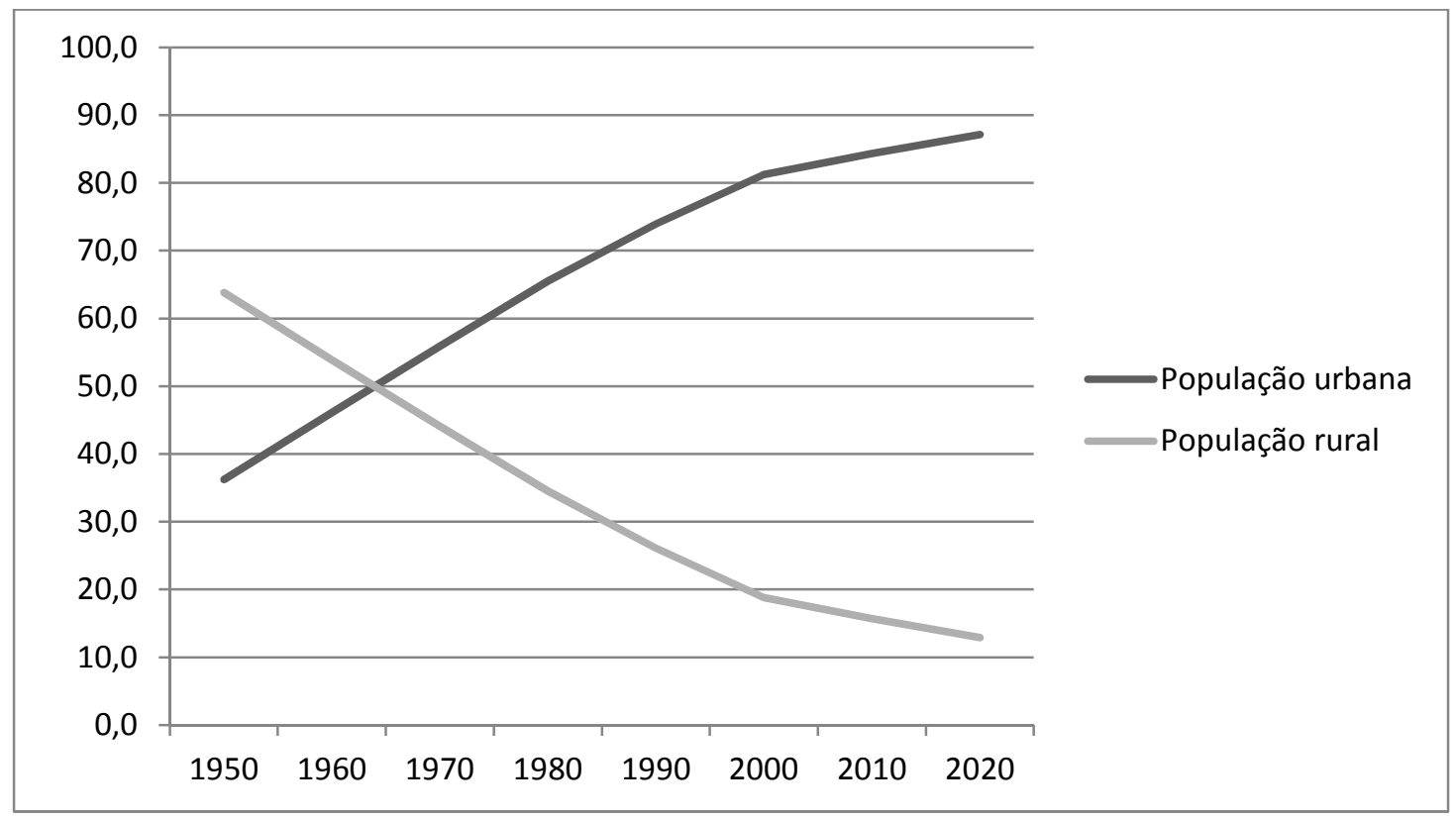

Taxa de urbanização no Brasil desde 1950. Fonte: ONU - World Urbanization Prospects 2018.

Alguns trabalhos já exploraram os reflexos específicos da dialética da acumulação entravada nas diversas realidades urbanas brasileiras: Adriana Gelpi -

\footnotetext{
${ }^{280}$ Ibidem.
} 
Rio Grande do Sul, processo de ocupação do território ${ }^{281}$; Simoni Campos - O Estado brasileiro e o processo de produção do espaço no Acre ${ }^{282}$; Luiz Felipe Brandão Reprodução social em Alagoas ${ }^{283}$; Adriano Libâneo - Dialética da organização espacia $^{284}$.

Dentre essas realidades, São Paulo, como centro dinâmico do processo econômico e social brasileiro durante o século XX, é um dos casos mais representativos. A origem de sua condição de centro econômico remonta a circunstâncias casuais - como a "posição geográfica", mais ou menos ao centro da costa brasileira -, mas que, aliadas à dinâmica característica de ocupação territorial no Brasil, seriam determinantes para a configuração do espaço nacional.

Com a transformação da Colônia em nação capitalista, o sentido colonial da economia brasileira, fundado nos ciclos a serviço do comércio internacional, foi atualizado com o chamado ciclo econômico do café. Durante o século XIX e início do seguinte, o café era o produto mais importante da pauta de exportação brasileira, sendo São Paulo seu maior produtor. Desse modo, renunciando a setores econômicos já consolidados e a áreas previamente ocupadas, deslocou-se a São Paulo grande parte dos capitais e da estrutura produtiva do País.

Ao invés de promover a articulação viária do País, o Estado brasileiro concentrou seus esforços na constituição de um sistema de transporte extremamente restrito, cuja única função era dar vazão ao fluxo das exportações. Trata-se das primeiras ferrovias brasileiras, que corriam paralelas de São Paulo ao litoral, ligando a produção de café aos principais portos de exportação ${ }^{285}$.

\footnotetext{
${ }^{281}$ GELPI, Adriana. Rio Grande do Sul, processo de ocupação do território. Tese de doutoramento. Universidade de São Paulo, Faculdade de Arquitetura e Urbanismo. 2003.

${ }^{282}$ CAMPOS, Simoni Martinoli. O Estado brasileiro e o processo de produção do espaço no Acre. Tese de doutoramento. Universidade de São Paulo, Faculdade de Arquitetura e Urbanismo. 2005.

${ }^{283}$ BRANDÃO, Luiz Felipe. O Estado e o mercado no processo de produção do espaço em Alagoas. Maceió: Fapeal, 2018.

${ }^{284}$ LIBÂNEO, Adriano Leonardi. Dialética da organização espacial: a metrópole de uma sociedade de elite. Tese de doutoramento. Universidade de São Paulo, Faculdade de Arquitetura e Urbanismo. 2013. 285 DEÁK, Csaba; SCHIFER, Sueli. The metropolis of an elite society. In SEGBERS, Klaus (Org.). The making of global city regions. Baltimore: John Hopkins University Press, 2007. p. 11.
} 
Somente com a queda irrecuperável dos preços do café, a partir de 1930, é que o Brasil, forçado por uma crise na Balança de Pagamentos, precisou reorientar sua economia para o mercado interno. O primeiro ensaio bem sucedido de industrialização não correspondeu, entretanto, ao fortalecimento de uma burguesia nacional. Ao contrário, foi viabilizado por meio da entrega a capitais estrangeiros, como no caso da indústria automobilística ${ }^{286}$.

Aproveitando uma força de trabalho assalariada já em estruturação, esse novo setor econômico instalou-se em São Paulo a partir de 1950. Sua principal característica era não apenas propor uma nova tecnologia de transportes, como também demandar a infra-estrutura para utilização de seus produtos. Com isso, em menos de 30 anos o Brasil interligou seu território por meio de rodovias, constituindo, finalmente, a condição necessária para um mercado nacional unificado ${ }^{287}$.

Como a expansão da malha rodoviária ocorreu a partir de São Paulo, sua posição central em relação ao espaço nacional permaneceu e lhe permitiu fomentar uma indústria mais complexa e menos frágil do que a do café, uma vez que a demanda interna diferia substancialmente da internacional quanto à diversidade e o nível de sofisticação produtiva dos bens ${ }^{288}$.

Com a rápida integração nacional e a concentração industrial - conseqüência também da crônica precariedade das infra-estruturas, concentradas na região sul São Paulo tornou-se um grande pólo de atração populacional, crescendo vertiginosamente. Tal fenômeno social é uma decorrência do processo de assalariamento que, no caso brasileiro, drenou para São Paulo, de uma só vez, grande parcela da imensa força de trabalho que havia sido preparada para o sistema

\footnotetext{
${ }^{286}$ Ibidem. p. 10.

${ }^{287}$ Ibidem.

${ }^{288}$ Ibidem. p. 11
} 
capitalista de produção desde meados do século XIX, com a Lei de Terras e a Abolição ${ }^{289}$.

De acordo com Sueli Schiffer, a concentração da atividade industrial em São Paulo acelerou-se no período entre 1950 e 1970, associada a uma forte atração das correntes migratórias. Ao passo desse movimento, intensificaram em São Paulo também as precárias condições em que se instalou a classe operária, ilustradas pelo crescimento das ocupações irregulares e da informalidade, aspectos, que, aliás, mantiveram sua expansão mesmo após a desconcentração industrial que teve início na década de 1970 e se estabilizou por volta de $1985^{290}$.

Embora um considerável número de trabalhadores tenha afluído a São Paulo motivado por o que pareceu ser uma repentina desobstrução do desenvolvimento capitalista do País, novos entraves reafirmaram o singular modo da acumulação brasileira. O baixo nível da reprodução da força de trabalho, em especial, as débeis condições urbanas, não apenas refletiram estágio extensivo no Brasil, mas foram também continuamente reiteradas como uma decorrência da dialética da acumulação entravada, do princípio de não reprodução legado da Colônia.

A reprodução dos trabalhadores, pouco importante na acumulação extensiva, encontrou lugar, na verdade, nos interstícios da economia que se conformava, na informalidade. E isso, como argumenta Francisco de Oliveira, não define uma dualidade, não compartimenta a economia brasileira em setores formais e informais, insolúveis entre si. É o que consubstancia a acumulação capitalista no Brasil a sua história precedente, dando-Ihe suas particulares feições ${ }^{291}$.

Para Oliveira, a dinâmica urbana e industrial requeria uma série de infraestruturas e serviços que os centros urbanos - como São Paulo e Rio de Janeiro

\footnotetext{
${ }^{289}$ DEÁK, Csaba. Falas e façanhas. In DEÁK, Csaba; SCHIFFER, Sueli (Org.). O processo de urbanização no brasil. São Paulo: Edusp, 2010. p. 16.

${ }^{290}$ SCHIFFER, Sueli Ramos. A dinâmica urbana e socioeconômica da região metropolitana de São Paulo: 1970-1975. In: SCHIFFER, Sueli Ramos (Org.). Globalização e estrutura urbana. São Paulo: Hucitec, 2004. p. $168 ; 191$.

${ }^{291}$ OLIVEIRA, Francisco de. Crítica à razão dualista e o ornitorrinco. São Paulo: Boitempo, 2013. p. 54.
} 
- não estavam preparados para suprir. Esse requerimento, então, foi resolvido mediante o crescimento não-capitalista do setor terciário, de serviços, prestados à base de pura força de trabalho, remunerada a níveis baixíssimos e visando, principalmente, à própria reprodução dos trabalhadores ${ }^{292}$.

Até hoje são essas as marcas do cotidiano urbano das grandes cidades brasileiras. Os vendedores ambulantes de comida e de acessórios em trens e estações do transporte coletivo. Os carrinhos de frutas e legumes nas portas das mesmas estações, vendendo àqueles que não chegarão em casa antes do comércio regular encerrar expediente. As tristes barraquinhas de brinquedos e roupas de crianças que, como presentes, tentam compensar ausências. Nas ruas de muitos bairros, os ofertantes de ovos e produtos granjeiros, de produtos de limpeza ("cândida"), de utensílios... As oficinas de reparo no fundo de quintal, as lavanderias improvisadas, as diaristas, os perueiros, os motoboys, o mutirão e o trabalho no final de semana empregados na construção das favelas, dos cortiços e toda sorte de habitações precárias.

Praticamente toda a informalidade consiste em serviços voltados à reprodução da força de trabalho, que preterida no processo social brasileiro, ocupa sempre condição marginal, periférica. Mas, paradoxalmente, a informalidade é o ramo mais "estável" da economia, em que, contemporaneamente, se socorrem muitos dos desempregados e que negócios oportunistas não tardam a aproveitar sob rótulo de modernidade. São as tecnologias de comunicação que agenciam a informalidade: os aplicativos tão aclamados como novos modelos de negócio. E que não deixam de ser, mostrando, sobretudo, a importância da reprodução dos trabalhadores na dinâmica econômica.

Mesmo os serviços públicos estruturados como o transporte coletivo, pela própria maneira como são operados, diluem o foco na promoção de direitos sociais - e, assim, na preocupação com a reprodução dos trabalhadores - a objetivos evocados

${ }^{292}$ Ibidem. 56-58. 
com grande força pela opinião pública, como a eficiência econômica e ambiental. É escamoteado, entretanto, o fato de que a taxa de passageiros transportados por veículo, por si só, constitui uma gigantesca vantagem econômica e ambiental do transporte coletivo sobre os modos individuais.

Resulta, assim, uma rede de transporte muito aquém das capacidades necessárias, em tamanho e desenho, e que impõem à população 2, 3 e, às vezes, até mais de 5 horas diárias no deslocamento casa-trabalho. Multiplicadas por milhões de trabalhadores, são horas desperdiçadas de trabalho, que poderiam ser usadas no aumento de produtividade (em estudo, em descanso, em lazer) e até para expansão do consumo, pois, nos longos percursos no transporte coletivo, os trabalhadores não consomem. Tal condição soa absurdo até mesmo para a mais fria racionalidade econômica.

$\mathrm{Na}$ questão de gênero, a precariedade da reprodução da força de trabalho tem também uma dimensão específica no Brasil. Pela segregação das atividades por identificação de gênero, que, no capitalismo e nas sociedades contemporâneas moralistas e conservadoras -, carimbou as mulheres no papel do trabalho reprodutivo, a informalidade no cotidiano brasileiro ganha um conteúdo ainda mais desigual. Como observa Oliveira, a precariedade da reprodução dos trabalhadores é suprida com a super-exploração da força de trabalho, especialmente, feminina ${ }^{293}$.

Para Luciana Itikawa, a informalidade na periferia do capitalismo reserva às mulheres uma dupla camada de exploração: o trabalho produtivo e reprodutivo. Trabalham não apenas para reproduzir o capital, mas também para reproduzir a força de trabalho, da qual fazem parte, tomando a si, desse modo, o maior fardo do ciclo vicioso da precariedade ${ }^{294}$.

Maquiada por mecanismo de "formalização" - como o microempreendedorismo - a informalidade é reiterada pela ausência e retirada de outros

\footnotetext{
293 Ibidem.

294 ITIKAWA, Luciana. Mulheres na periferia do urbanismo. Buenos Aires: CLACSO, 2015. p. 94.
} 
direitos sociais, como a posse da moradia. Com isso, os trabalhadores informais, em especial as mulheres, estão condicionados a uma perene subordinação à dinâmica econômica e em estreita vinculação com a produção do espaço, às custas da reprodução da força de trabalho, que Ihes impõe constantes realocações, perpetuando sua informalidade ${ }^{295}$.

Nesse sentido, Yvonne Mautner mostra como um arranjo entre a expansão do capital e da periferia sujeita a estruturação urbana de São Paulo. Para a autora, a produção do espaço urbano em São Paulo acontece mediante três camadas de trabalho. Em um primeiro momento, quando as abundantes necessidades da população precisam ser satisfeitas, ainda que debilmente, a terra é transformada por meio do "trabalho puro" ou "individual": ocupa-se irregularmente e constroem-se, com uma grande parcela de trabalho não-assalariado na forma de mutirão ou autoconstrução, casas e logradouros precários que seguem o mais próximo possível o padrão da cidade legal ${ }^{296}$.

Em seguida, uma vez estabelecidos os assentamentos, a pressão criada pela demanda por serviços públicos e infra-estruturas leva o Estado a legalizar e intervir nos loteamentos irregulares, o que caracteriza uma segunda camada de trabalho, chamado pela autora de "trabalho coletivo". Por fim, em uma última etapa de transformação, marcada pela entrada do "capital" como a terceira camada de trabalho, os loteamentos são definitivamente incorporados à cidade e sua população original é forçada a reiniciar o processo em um ciclo que, dessa maneira, configura a "periferia como fronteira de expansão do capital"297.

Nessa dinâmica, portanto, o Estado cumpre relevante papel na efetivação do processo capitalista. No entanto, em nada se assemelha à ação governamental característica de uma acumulação desimpedida, em que a atuação do Estado se

\footnotetext{
295 Ibidem.

${ }^{296}$ MAUTNER, Yvonne. A periferia como fronteira de expansão do capital. In DEÁK, Csaba; SCHIFFER, Sueli (Orgs.). O processo de urbanização no brasil. 1a ed. 1999, 2a ed. São Paulo: Edusp, 2010. p. 256;

297 Ibidem. p. 256 e 257.
} 
antecipa, por meio de planejamento, à ocupação urbana. Como salienta Marta Dora Grostein, não só a legalização de loteamentos e propriedades irregulares constituiu a ação do Estado sobre a estruturação urbana em São Paulo, como também a própria manutenção das condições para que essa "irregularidade" continuasse a ocorrer ${ }^{298}$.

Esse princípio ainda se desdobra em uma questão ambiental. Para Ermínia Maricato, o fato de a terra formal para moradia não estar inclusa no pacote dos direitos sociais nem ser um item compatível com capacidade de aquisição dos salários de grande parte da população - inclusive de classe média - força a ocupação das áreas excluídas pelo mercado, ambientalmente frágeis. Isso acaba por ampliar a debilidade da reprodução dos trabalhadores, submetidos a riscos geológicos, hidrológicos e relacionados ao saneamento precário ${ }^{299}$.

Em meados do século XX, generalizou-se no Brasil a doutrina econômica do desenvolvimentismo, endereçada ao tratamento de toda essa realidade. Em alinhamento às experiências da Social-Democracia, do keynesianismo e do Estado de Bem-Estar, forma ideológica da acumulação intensiva nos países de capitalismo avançado, o desenvolvimentismo consistiu em um ciclo ideológico cujo arcabouço técnico, analítico e propositivo não encontrou correspondência na base material brasileira, em pleno desenvolvimento extensivo e presa ao seu sentido colonial. As concepções desenvolvimentistas não tiveram, por isso, efetividade.

De acordo com Ricardo Bielschowsky, o desenvolvimentismo pode ser definido como a ideologia de superação do subdesenvolvimento brasileiro por meio de um projeto de industrialização coordenado e impelido pelo Estado. No núcleo do argumento desenvolvimentista estava a concepção de que a situação nacional só poderia ser vencida com a modificação de sua estrutura produtiva, saindo de uma

\footnotetext{
${ }^{298}$ GROSTEIN, Marta Dora. A cidade clandestina: ritos e mitos. Universidade de São Paulo, Faculdade de Arquitetura e Urbanismo. Tese de doutoramento. São Paulo, 1987. p. 538.

${ }^{299}$ MARICATO, Ermínia. Metrópole, legislação e desigualdade. Estudos Avançados. 17 (48). São Paulo: IEA-USP, 2003. p. 158.
} 
base agrícola e extrativista para uma economia industrial, em um processo que se acreditava impossível de ser alcançado pelas forças espontâneas de mercado ${ }^{300}$.

Prescrevia-se, desse modo, uma transformação econômica planejada e com a participação direta do Estado. As discussões centravam-se no papel específico do Estado nesse processo, seja como agente orientador da expansão, como financiador das operações e captador de recursos externos, ou como provedor de investimentos nos setores em que a iniciativa privada não seria capaz de fazê-lo ${ }^{301}$.

As ações mais próximas ao reconhecimento da importância da reprodução da força de trabalho estavam nas propostas de planejamento urbano e na pressão de movimentos populares, que compunham a conjuntura política e social do desenvolvimentismo. Apesar de presentes nas preocupações de economistas como Roberto Simonsen e Celso Furtado, as questões relativas à reprodução dos trabalhadores, atinentes às demandas mais tangíveis da população, eram temas mais freqüentes nos planos e estudos urbanísticos, pelo seu próprio escopo, e também nas manifestações do chamado movimento político das reformas de base.

É comum na historiografia a acepção de que os ensaios desenvolvimentistas tiveram seu ápice durante a década de 1960 e 1970 no Brasil. Contudo, esses ensaios foram sempre um hibridismo entre diagnósticos e ações restritivas nos campos monetário, cambial e fiscal, com componentes de uma abordagem de desenvolvimento econômico.

Uma de suas expressões mais bem delineadas foi o Plano Trienal de Desenvolvimento Econômico e Social, concebido em 1962 sob coordenação de Celso Furtado. De acordo com Roberto Macedo, seus principais pontos eram a retomada do crescimento econômico; o controle progressivo da inflação; a redistribuição de renda, tanto entre classes socais como entre regiões; a renegociação dos prazos da dívida

\footnotetext{
300 BIELSCHOWSKY, Ricardo. Pensamento econômico brasileiro: o ciclo ideológico do desenvolvimentismo. Rio de Janeiro: Contraponto, 2000. p. 7.

${ }^{301}$ Ibidem.
} 
externa; e a realização das reformas de base, em especial, as reformas administrativa, fiscal, agrária e do sistema financeiro ${ }^{302}$.

Embora previstas no Plano Trienal, as reformas, principalmente as de caráter mais social, extrapolaram o âmbito do plano e passaram a ser discutidas e reivindicadas em um movimento mais amplo, no movimento das reformas de base. Destaca-se, além da reforma agrária - que visava a dar solução à pressão social no campo -, o movimento pela reforma urbana, o qual, como complementar à primeira, tinha por objetivo aliviar as condições de reprodução da força de trabalho nas cidades, especialmente por meio da redistribuição da propriedade urbana ${ }^{303}$.

Um dos marcos do movimento pela reforma urbana foi o Seminário de Habitação e Reforma Urbana, realizado em 1963, no hotel Quitandinha, em PetrópolisRJ. Roberto Loeb observa que a importância do Encontro de Quitandinha, como ficou conhecido o Seminário, decorre do fato de esse ter se constituído como uma das primeiras articulações para associar a questão urbana à política nacional, o que teria prosseguimento com a criação do Serviço Federal de Habitação e Urbanismo (SERFHAU) em $1964^{304}$.

No campo específico do urbanismo, destacam-se os estudos promovidos por organizações de alguma forma vinculadas aos círculos próximos à Igreja Católica e a sua "doutrina social". Era nas atividades do Padre Louis Joseph Lebret que isso teve maior expressão.

Segundo Heitor Ferreira Lima, os trabalhos de Lebret foram um dos três componentes do pensamento desenvolvimentista no Brasil. Ao lado das idéias da CEPAL e da teoria francesa dos pólos de desenvolvimento, as concepções de Lebret contribuíram, com fundamentos tanto técnicos como morais, para a formação do desenvolvimentismo. Ferreira Lima cita, especificamente, o estudo elaborado por

\footnotetext{
302 MACEDO, Roberto B. M. Plano Trienal de Desenvolvimento Econômico e Social (1963-1965). In: MINDLIN, Betty. Planejamento no Brasil. São Paulo: Perspectiva, 2003. p. 53-54.

${ }^{303}$ FAUSTO, Boris. História do Brasil. São Paulo: Companhia das Letras, 2011. p. 380-383.

${ }^{304}$ LOEB, Roberto. Aspectos do planejamento territorial e urbano no Brasil. In: MINDLIN, Betty.
} Planejamento no Brasil. São Paulo: Perspectiva, 2003. p. 153. 
Lebret para a Comissão de Desenvolvimento Econômico de Pernambuco (CODEPE) em 1955, o qual possivelmente teve reflexos sobre os trabalhos da Superintendência do Desenvolvimento do Nordeste (SUDENE), referência no contexto do desenvolvimentismo ${ }^{305}$.

Posicionando-se contra o capitalismo liberal e o comunismo, Lebret defendia uma "terceira via" de desenvolvimento. Sua concepção estava embasada em princípios humanísticos e pressupunha, sobretudo, uma planificação econômica guiada por um órgão regulador supranacional, que abrangia desde unidades territoriais elementares à conjuntura mundial ${ }^{306}$.

No Brasil, Lebret esteve à frente do movimento Economia e Humanismo e na formação de grupos de técnicos como a Sociedade de Análises Gráficas e Mecanográficas Aplicadas aos Complexos Sociais (SAGMACS). Desses grupos resultaram importantes trabalhos sobre questões urbanas, como o "Estudo sobre a Aglomeração Urbana de São Paulo", de 1957, e o Plano Urbanístico Básico de São Paulo, de 1968. Apesar dos diagnósticos precisos e de suas propostas abrangentes, tais trabalhos tiveram efetividade praticamente nula.

As proposições básicas do desenvolvimentismo ainda permearam projetos governamentais na década de 1970. Na esfera urbana isso estava relacionado às atividades dos primeiro órgãos nacionais voltados ao tema, como SERFHAU, o Banco Nacional de Habitação $(\mathrm{BNH})$ e à uma política urbana nacional, componente do segundo Plano Nacional de Desenvolvimento (PND II).

Porém, o movimento de distensão e as chamadas políticas de ajustamento constituíram o rápido e inconseqüente abandono das concepções desenvolvimentistas, encerrando seu ciclo ideológico com poucos resultados práticos. Em 1988, a

\footnotetext{
305 LIMA, Heitor Ferreira. História do pensamento econômico no Brasil. São Paulo: Editora Nacional, 1978. p. 187.

${ }^{306}$ LEBRET, Louis Joseph. Manifesto por uma civilização solidária. São Paulo: Duas Cidades, 1962. p. $27 ; 37 ; 89$.
} 
Constituição, em seus Artigos 182 e 183, legou explicitamente aos municípios a condução da política urbana, fragmentando-a e fragilizando seus objetivos

Obstaculizados pela demora na institucionalização de mecanismos legais que Ihe dariam efetividade - o Estatuto da Cidade (lei 10.457), que só foi aprovado em 2001 -, esses preceitos constitucionais ainda abriram espaço para ampla incorporação do ideário neoliberal na prática do planejamento urbano. As chamadas operações urbanas, os instrumentos de mercado - como outorga onerosa do direito de construir, transferência do potencial construtivo, etc. - e as intervenções pontuais de projetos urbanos foram absorvidos como fórmulas que, por si só, desencadeariam o processo de renovação da conjuntura urbana.

Como observa Luiz Felipe Brandão, sob a imagem de conceitos progressistas, porém vagamente definidos - como justiça social, direito à cidade, função social da propriedade, participação - o ideário neoliberal deslocou a idéia de intervenção sistemática do Estado sobre a realidade urbana ${ }^{307}$. Especificamente, relativizou, se não mesmo apagou, os objetivos básicos da política urbana, focados na ampliação de direitos sociais - transporte, habitação, educação... - e, enfim, no melhoramento dos níveis das condições de reprodução da força de trabalho.

Mesmo as experiências recentes de governos reformistas não foram além de ações titubeantes e insuficientes na superação da precariedade do cotidiano brasileiro. Com programas de investimento fragmentários e de concessão de crédito habitacional que não alcançaram boa parte da população necessitada, a política fiscal do governo na primeira década dos anos 2000 foi incapaz de corrigir as deficiências sociais do País. Além disso, apoiou-se na receita do ajustamento neoliberal para legitimar uma rígida política restritiva nos demais campos da política fiscal e monetária, o que acabou enfraquecendo ainda mais seus objetivos sociais.

É importante ter em mente, contudo, que a retórica neoliberal não intensificou ou constituiu uma modificação real da prática do Estado brasileiro vigente até então.

${ }^{307}$ BRANDÃO, Luiz Felipe. Op. Cit., 2018. p. 159-162. 
Se nos países onde teve origem o neoliberalismo representou o reconhecimento e a tentativa de negação da crise decorrente da dialética do mercado e do Estado, no estágio intensivo de acumulação, no Brasil essa forma ideológica encobriu e legitimou a acumulação extensiva que permitiu a sobrevida do constructo social emerso e perpetuado desde os tempos coloniais, mas que, ora, encontra sua crise. .

A crise que se instaura contemporaneamente no Brasil, como aponta Alysson Mascaro, tem amplas bases e amplos sentidos. Configura-se como determinação do desenvolvimento de sua base material, mas também como sobredeterminação de suas superestruturas institucionais. Além disso, monta-se sobre diferentes níveis de crise, de ordem econômica mundial e de forma-política ${ }^{308}$.

O ponto específico desta tese é que o esgotamento da acumulação extensiva no Brasil, que corresponde, como argumentado, à exaustão da urbanização, ora consumada, compele a organização social brasileira a uma crise, que se arrasta desde o final do século XX. O que se argumenta é que a reprodução dos trabalhadores é algo central nessa crise. Defende-se, especificamente, que sua leitura no processo social brasileiro estabelece um ponto de vista privilegiado, de onde é possível apontar o olhar para quatro direções: para o passado, para o futuro, para as estruturas do cotidiano e para a possibilidade de cotejamento da formação social no Brasil a outros processos sociais contemporâneos.

O primeiro desses ponteiros é o que Luiz Felipe de Alencastro chamou de o componente de longa duração da história brasileira. É a não reprodução da força de trabalho o que perpassa, como elemento comum, toda a existência e constituição da sociedade brasileira. É a essência que permite costurar os tão diversos episódios da história brasileira em uma só linha narrativa. Esse elemento reside, na escravidão e no colonato, na simples extraterritorialidade dessa reprodução - como interpreta Alencastro -, e está, durante o século XX e a existência capitalista do Brasil, na acumulação extensiva, que - como esclarece Csaba Deák - prescinde também dessa

${ }^{308}$ MASCARO, Alysson Leandro. Crise e golpe. São Paulo: Boitempo, 2018. p. 23-32. 
reprodução e que se alimenta também de certa extraterritorialidade: o contingente migratório que compôs a urbanização brasileira.

O segundo ponteiro indica o futuro, pois constitui a imposição da crise inescapável e que, inescapavelmente, exigirá seu tratamento pela sociedade que seguirá existindo. Como comentado, a exaustão da população a ser assalariada, assimilada pelo processo de extensão capitalista, implica o fim das altas taxas de excedente e a incorporação dos custos de reprodução da força de trabalho, visando ao aumento de produtividade. De outro modo, isso significa o fim do princípio de não reprodução dos trabalhadores e, assim, de todos os expedientes sobre quais estão montadas as relações sociais no Brasil.

Além disso, como elemento que estabelece o impasse, que se constitui como problema, o imperativo da reprodução dos trabalhadores é também o que requer solução. Seja a passagem a um regime de acumulação intensiva ou a superação da crise latente nessa própria passagem - decorrente da dialética do mercado e do Estado -, o objetivo central da transformação passará, necessariamente, pela questão da reprodução da força de trabalho.

Exige, portanto, mais do que um projeto de industrialização, do que o fortalecimento de classes reformistas, do que o amadurecimento dos chamados interesses nacionais, do que o controle eficiente sobre recursos naturais finitos ou do que a regulação de variáveis econômicas complexas. Essa transformação incluirá, sobretudo, uma maneira de lidar com a reprodução dos trabalhadores, de garanti-la a níveis plenos e a permitir o exercício da verdadeira cidadania.

Isso chama o terceiro ponteiro, o olhar para os aspectos tangíveis da economia, para as estruturas do cotidiano a que se refere Braudel. Trata-se, em especial, da realidade urbana a que está condicionada a sociedade brasileira contemporânea e que caracteriza também, com o avanço da urbanização mundial, um futuro comum entre as nações. São os serviços e infra-estruturas urbanas que mais diretamente aparelham a força de trabalho na transição da acumulação extensiva à acumulação 
intensiva, ou ao que sua crise seguir. Dão, por isso, sentido e objetivos muito palpáveis a seu planejamento.

E planejamento, nesse caso, significa ação do Estado. Pelas limitações do mercado na provisão desses serviços e infra-estruturas, mas também por implicar uma visão de longo prazo, tal transformação, em ambas as transições - à acumulação intensiva e à sucessão da crise capitalista -, só é possível em uma instância de regulação social coletiva e centralizada, da qual não se conhece outra a não ser o Estado.

Por fim, uma vez que a reprodução da força de trabalho é aspecto pertinente a qualquer formação social, torna-se certo tipo de categoria transfronteiriça que serve ao cotejamento de distintos processos sociais. Esse é o quarto ponteiro, que o exercício a seguir busca experimentar no contraponto estabelecido entre o processo urbano brasileiro e o chinês, mediante a exploração da hipótese de que ambos os países enfrentam a crise de exaustão da acumulação extensiva. 


\subsection{Contraponto da China}

Tanto o Brasil quanto a China defrontam-se com a necessidade de encaminhar um mesmo impasse material: a crise da acumulação extensiva. Esse impasse se estabeleceu no Brasil por volta dos anos 1990, com a exaustão do processo de acumulação extensiva, verificado no esgotamento da urbanização brasileira ${ }^{309}$, como anteriormente explanado. Na China, o avanço da urbanização indica o desgaste desse mesmo processo econômico.

Para o Brasil, essa transição tem caráter revolucionário, implica uma considerável modificação da base material em que se apoiou a sociedade brasileira desde a Colônia. Para a China, essa transformação não é de menor grandeza, e já se encontra expressa nos discursos oficiais, embora lá a transição seja um desdobramento da revolução em curso desde meados do século XX.

Em 2012, simbólico ano do dragão e data em que a população urbana do país apresentou, pela primeira vez, prevalência nas taxas demográficas - data, por isso, não aleatoriamente escolhida, como observa Clodoaldo Hugueney -, houve a transição da quarta para a quinta geração de burocratas do governo chinês (politburo), com o anúncio de uma nova agenda estatal e cujos elementos se encontram presentes nos $11^{\circ}(2006-2011)$ e $12^{\circ}$ (2011-2015) Planos Quinquenais ${ }^{310}$.

Com o diagnóstico de que a economia chinesa não poderia mais sustentar crescimentos à razão de dois dígitos - crescimento do PIB acima de 10\% ao ano -, como havia sido até então, prescreveu-se uma radical mudança no "modo de desenvolvimento chinês", com a passagem de um "estágio extensivo" a um "estágio intensivo" de desenvolvimento ${ }^{311}$.

\footnotetext{
${ }^{309}$ DEÁK, Csaba. Acumulação entravada no Brasil e a crise dos anos 1980. In DEÁK, Csaba; SCHIFFER, Sueli (Org.). O processo de urbanização no brasil. São Paulo: Edusp, 2010. p. 38.

${ }^{310}$ HUGUENEY, Clodoaldo Filho. Para onde vai a China sob a quinta geração. Revista de Política Externa. Vol. 22, N. 2. São Paulo: Paz e Terra, 2013.

311 Ibidem.
} 
Chama a atenção o emprego de termos e conceitos como os aqui adotados, considerados, no discurso oficial, como parte da "abordagem científica" na administração governamental. A mudança no "modo de desenvolvimento chinês", condicionada à passagem do "estágio extensivo" ao "estágio intensivo", implica, de acordo com os trabalhos do próprio Instituto Chinês para Reforma e Desenvolvimento, a expansão da infraestrutura urbana, regional, nacional e sua integração interna e externa, assim como, as adequações institucionais e macroeconômicas à necessidade do desenvolvimento social e ambiental no País ${ }^{312}$.

Isso inclui a reforma do sistema hukou - sistema de seguridade social baseado em domicílio fixo, a seguir explanado -, o incentivo ao aperfeiçoamento tecnológico, com investimentos consideráveis em desenvolvimento sustentável, e um novo eixo de orientação e agregação de valor à produção interna, antes voltada especialmente à exportação ${ }^{313}$.

Ainda que tal discurso possa ser carregado de forte componente retórico, representa uma ação real do Estado chinês no sentido da reforma de sua dinâmica econômica e social. Essa reforma está diretamente, e explicitamente, ligada às questões urbanas. Em um prazo de 10 anos, a China será um país virtualmente urbanizado, com quase $70 \%$ de sua população vivendo em cidades - números alcançados pelo Brasil há mais de três décadas ${ }^{314}$.

Além disso, como o Brasil, a China vivencia agora a transição para chamada fase quatro do modelo de Warren Thompson ${ }^{315}$. Também conhecido como janela demográfica, esse momento marca o estágio em que a população economicamente ativa prevalece na composição demográfica de um país, constituindo, assim, importante período para o desenvolvimento nacional. Sua relevância decorre do fato

\footnotetext{
${ }^{312}$ CHANG, Xiuze. China's mode of development. In: CHINA, Institute for Reform and Development. 30 years of China's Reform. Beijing: Foreign Languages Press, 2008.

313 Ibidem.

${ }^{314}$ ONU, World Population Prospects. Disponível em: http://esa.un.org/unpd/wpp/. Acesso em: $30 / 07 / 2015$.

${ }^{315}$ Ibidem.
} 
de que a rápida transição para a fase seguinte, na qual a proporção entre população economicamente ativa e inativa é invertida, envolve significativas reduções nas taxas de acumulação, assim como, o aumento dos custos previdenciários e da pressão sobre a população mais jovem.

Tais estatísticas confirmam o esgotamento de qualquer modelo econômico baseado no assalariamento e na incorporação extensiva de trabalhadores. A manutenção das taxas de excedente depende progressivamente agora, tanto na China quanto no Brasil, do aumento da produtividade. Tal aumento, por sua vez, está fundamentalmente relacionado ao aparelhamento da força de trabalho e ao aumento do nível das condições de sua reprodução.

Anunciada na China e atrasada no Brasil, essa transformação ainda não se efetivou em ambos os países. O fato de Brasil e China alcançarem esse momento histórico em certa simultaneidade torna, portanto, o cotejamento entre o processo urbano brasileiro e o chinês algo possível e pertinente. Seus encaminhamentos, ainda que diversos, respondem a um mesmo desafio material, a passagem de um regime extensivo a um regime intensivo de acumulação.

Além disso, na atual conjuntura mundial - com a deterioração do quadro ambiental e taxas de urbanização mundiais nunca antes vivenciadas -, esses encaminhamentos não encontram paralelos na história, fazendo mesmo do caso brasileiro e chinês talvez os únicos pares de comparação possíveis. Suas escolhas pelo desenvolvimento das forças produtivas não apenas constituem formas comparáveis de tratamento, endereçadas a essa realidade específica, como também pesam consideravelmente, pelas suas próprias dimensões, na definição dos rumos do desenvolvimento mundial.

Quaisquer que sejam essas escolhas, todas acarretam a elevação das condições de reprodução da força de trabalho. A efetividade de qualquer ação em prol da intensificação das forças produtivas significa um aumento real da produtividade do 
trabalho e, para que isso aconteça, é também essencial um melhoramento na maneira como se reproduz a classe trabalhadora.

Esse é o elemento, portanto, que, em um mesmo plano conceitual, possibilita o cotejamento desses processos sociais tão distintos, entre Brasil e China. Resgata o liame específico de suas trajetórias históricas e descortina a oportunidade de vislumbrar aspectos essenciais de seu desenvolvimento futuro, os quais, diante da crise posta à reprodução ampliada na escala global, podem ser pensados em conjunto, como um efeito comum.

Segue algumas observações que trilham esse argumento.

Nos discursos oficiais contemporâneos, a China é apresentada como uma "economia de mercado socialista", como conceituou o presidente Xi Jinping. Essa economia é conduzida por duas instâncias de regulação, o mercado e o Estado. Nas palavras de Xi Jinping, a economia chinesa é conduzida pela a "mão invisível" e pela a "mão visível” ${ }^{316}$.

Trata-se de dois princípios sociais de alocação de recursos, cuja interação, segundo Xi Jinping, não constitui um antagonismo e na qual a expansão do primeiro é o objetivo fundamental da Reforma, que continua desde 1978. Isto é, para o governo chinês, o mercado deve ter papel decisivo na alocação direta de recursos e promover a reforma significa aprofundar a mercadorização da economia, reduzindo a intervenção direta do Estado nas atividades microeconômicas ${ }^{317}$.

Concluí-se, pois, que a economia chinesa guarda semelhanças com as economias de mercado capitalistas. Porém, lá os pólos da primazia na regulação da produção social estão invertidos. O âmbito descentralizado do mercado sempre esteve submetido à regulação centralizada do Estado, fato que um dos principais objetivos da Reforma ilustra.

\footnotetext{
${ }^{316} \mathrm{XI}$, Jinping. A Governança da China. Vol. I. Rio de Janeiro: Contraponto/Foreign Languages Press, 2019. p. 141-144.

${ }^{317}$ Ibidem.
} 
A primazia do mercado na alocação direta de recursos que a Reforma persegue, contudo, não pode ser o mesmo que a primazia na regulação da produção social como um todo. Para dar continuidade ao crescimento econômico, de acordo com seu próprio diagnóstico, a sociedade chinesa precisa intensificar as forças produtivas. Particularmente, isso está associado ao aumento da produtividade da força de trabalho por meio da elevação do nível das condições de sua reprodução. Uma vez que tal elevação só é possível com a expansão da esfera da produção regulada pelo Estado, com a expansão de infraestruturas, sua diminuição em favor do aprofundamento da "mercadorização", em favor da ampliação da forma-mercadoria, é inviável.

Assim, a menos que abandone seu princípio de reprodução ampliada, a sociedade chinesa não tenderá "a uma regressão à média", à tendência das sociedades de mercado contemporâneas, que enfrentam a crise da dialética entre mercado e Estado. Mais do que isso, a inversão - por assim dizer, natural - dos pólos da primazia da regulação social na China, dos pólos do mercado e do Estado, configura uma vantagem ao desenvolvimento chinês, um estágio avançado e socialmente resolvido entre os mecanismos descentralizados e centralizados de regulação da produção.

Na prática, o que encaminha a reprodução social na China em sentido contrário a uma regressão à trajetória e à crise das sociedades capitalistas - pode-se dizer, sociedades de mercado convencionais - é a constante preocupação com o desenvolvimento de longo prazo, tratável apenas no âmbito centralizado de regulação do Estado, isto é, por meio do planejamento. Essa preocupação está explícita no reconhecimento da necessidade de reprodução da força de trabalho, identificada no tratamento prioritário às questões urbanas e em sua clara vinculação com 0 desenvolvimento econômico, como anuncia a Nova Estratégia Urbana da China (NEU), a seguir discutida. 
O desenvolvimento econômico na China contemporânea está estritamente relacionado a seu processo de urbanização, que acelerou a partir da reforma de 1978. O gráfico a seguir mostra a evolução da taxa de urbanização na China, com visível acentuação depois da década de 1980.

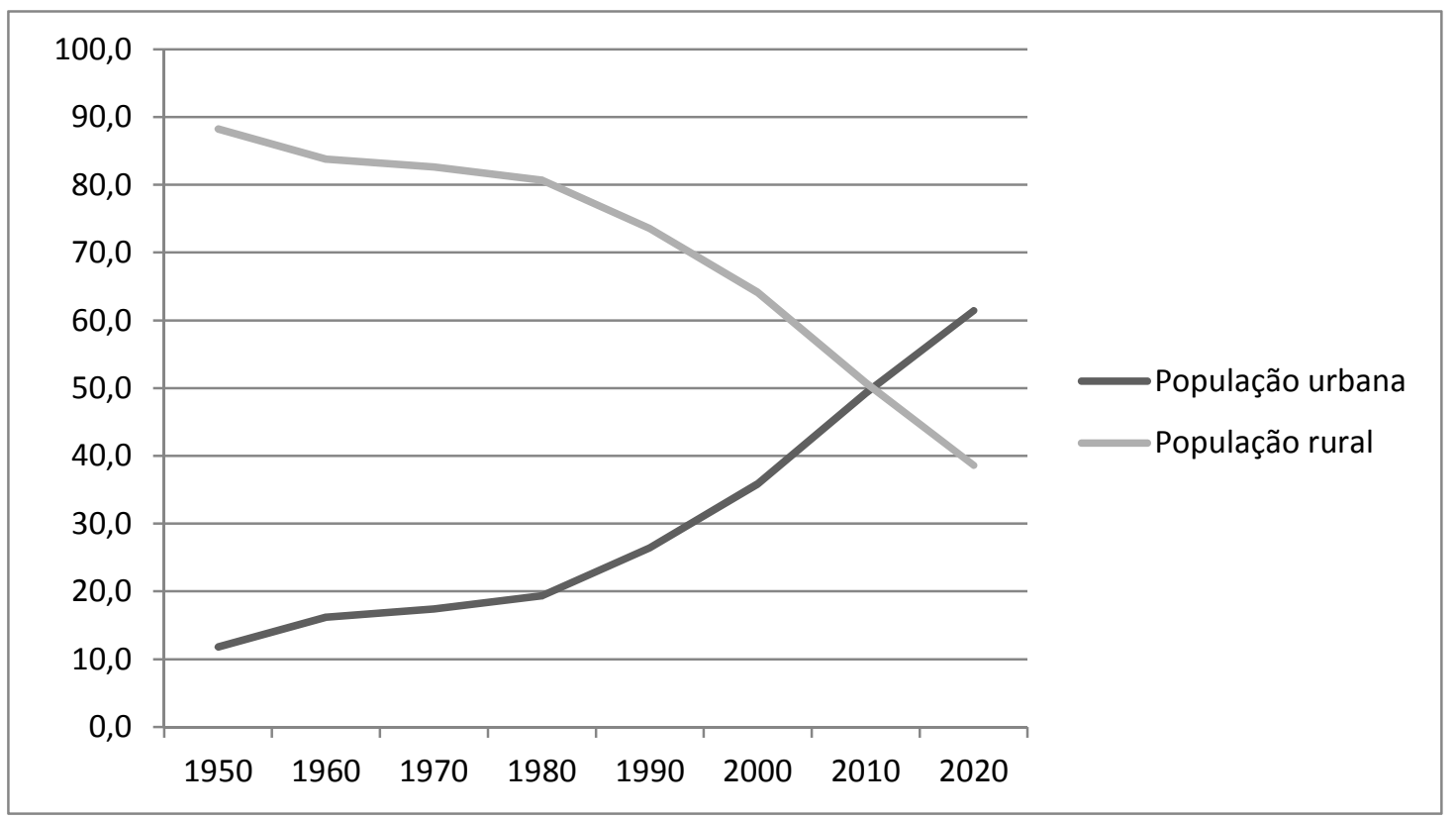

Taxa de urbanização na China desde 1950. Fonte: ONU - World Urbanization Prospects 2018.

Apesar das muitas peculiaridades que a China apresenta, seu desenvolvimento econômico extensivo não foi, na essência, diferente da acumulação extensiva capitalista. Baseou-se na incorporação de trabalhadores que não eram reproduzidos pela nova dinâmica econômica e, como em outros países, tem intrínseca relação com urbanização.

Por muito tempo a maior parte da força de trabalho na China se reproduziu mediante seu laço com a terra, como campesinato. Esse campesinato se constituiu ao longo da história chinesa ao mesmo passo do estabelecimento de uma forma peculiar de feudalismo. Segundo Wladimir Pomar, há mais de dois mil anos estabeleceu-se na 
China um tipo de "feudalismo centralizado", controlado, ou regulado, por um Estado imperial $^{318}$.

Tido por alguns autores como um modo de produção específico - o chamado modo de produção asiático -, esse sistema tinha as mesmas características básicas do feudalismo europeu, com a posse coletiva da terra detida pelos camponeses. Entretanto, as colheitas e os excedentes eram assegurados em larga escala pela administração do Império e por meio da construção de grandes infraestruturas de irrigação, armazenagem e logística ${ }^{319}$.

Em certo sentido, pode-se dizer que esse ajuste centralizador cumpria o papel que o mercado teve no feudalismo europeu de regular, ou dar vazão, ao excedente dos feudos isolados. Mas ao contrário do mercado no feudalismo da Europa, a centralização do Império chinês não constitui um antagonismo ao poder descentralizado da nobreza agrária e ajudou, na verdade, a manter praticamente intacto o arranjo reprodutivo camponês até o século XX.

Embora a evolução desse sistema não esteja isenta de conflitos, desequilíbrios e episódios divergentes, como as gigantescas revoltas camponeses do século VII, conduzidas pelo líder camponês Liu Bang, ou a considerável ascensão comercial e urbana da dinastia Yuan - o kanato de Gengis Khan -, a materialidade da China permaneceu sólida e majoritariamente ancorada no campesinato ${ }^{320}$.

No século XX, os camponeses foram a base da Revolução. Profundamente estudada por Mao Zedong, a realidade camponesa constitui-se como o principal eixo viabilizador da transformação proposta pelo Partido Comunista. Mesmo após a instalação da República Popular, iniciativas de industrialização fundaram-se ainda na estrutura camponesa. Entre 1953 e 1957, pesados impostos e trabalhos voluntários

\footnotetext{
${ }^{318}$ POMAR, Wladimir. O enigma chinês. São Paulo: Fundação Perseu Abramo, 2015. p. 70-74.

${ }^{319}$ Ibidem.

${ }^{320}$ Idem. A revolução chinesa. São Paulo: Unesp, 2004. p. 24-30.
} 
fizeram com que a renda das famílias camponesas caísse mais de $20 \%$ e a fome endêmica tomasse conta do País ${ }^{321}$.

No projeto do "grande salto para frente", a expansão da produção de aço baseava-se na produção doméstica de milhões de famílias camponesas, que utilizavam alto-fornos improvisados em fundos de quintal. Além disso, outros milhões de camponeses foram deslocados para a produção de infraestruturas. O resultado foi desastroso. Os inadequados padrões da produção doméstica levaram a uma péssima qualidade do aço; a logística improvisada do carvão e do minério transformou o sistema de transporte no caos; e a produção agrícola e de subsistência novamente foi prejudicada $^{322}$.

No decorrer das décadas de 1960 e 1970, a China passou por instabilidades políticas e econômicas que levaram a concepção de um programa de reformas. Em 1977, sob o comando de Deng Xiaoping, essas reformas foram oficialmente apresentadas e enfocavam quatro modernizações, relativas a aperfeiçoamentos na agricultura, na indústria, na defesa e na área de ciência e tecnologia. Conduzida com um grau de abertura ao mercado, a Reforma expandiu rapidamente a produção com a reorganização da indústria e transformação de camponeses em assalariados urbanos, intensificando, consequentemente, a urbanização ${ }^{323}$.

A migração campo-cidade, contudo, não cresceu no mesmo ritmo que o aumento da expansão dos rendimentos e dos direitos dos trabalhadores migrantes. $\mathrm{Na}$ China, grande parte do contingente dos trabalhadores urbanos é composto por pessoas que ainda retêm um registro hukou rural, o que os impede de serem beneficiados pelo sistema de seguridade social e estabelecer domicílio fixo nas cidades $^{324}$.

\footnotetext{
321 Ibidem. p. 90-98.

322 Ibidem.

${ }^{323}$ XIE, Chuntao (Org.). China through the ages. Vol II. Beijing: New World Press, 2009. p. 149-176.

${ }^{324}$ CHINA DEVELOPMENT RESEARCH FOUNDATION. China's new urbanization strategy. Londres: Routledge, 2013. p. 33-34.
} 
O sistema hukou foi implantado nos 1950 como um mecanismo de planejamento econômico para organizar a alocação de trabalho, produtos e serviços. Os domicílios eram classificados entre registros urbanos e rurais, condição que as pessoas herdam de suas famílias e somente pode ser alterada, com grande dificuldade, mediante decisão governamental. Efetivamente, o sistema hukou determina o local de residência, a ocupação e o acesso a serviços públicos dos indivíduos ${ }^{325}$.

No sistema hukou, trabalhadores urbanos têm a garantia de um programa de seguridade social muito mais amplo do que os trabalhadores rurais. Desfrutam de educação gratuita, estabilidade no emprego, subsídios habitacionais, sistema de saúde e aposentadoria. Os trabalhadores rurais, por sua vinculação com a posse coletiva da terra e a inviabilidade de estender todos os benefícios do Bem-Estar a toda população, são assegurados pela subsistência do campo ${ }^{326}$.

A manutenção da propriedade coletiva da terra fizeram com que Giovanni Arrighi considerasse o desenvolvimento chinês como um caso atípico de acumulação, isto é, sem desapropriação ${ }^{327}$. Entretanto, além de caracterizar uma sociedade dual e falha em garantir proteção total aos trabalhadores ${ }^{328}$ - o que, na visão de críticos, aproximou a China a uma sociedade de castas -, o desenvolvimento econômico chinês baseou-se em uma flexibilização do sistema hukou, que criou uma enorme massa de trabalhadores migrantes sem diretos que se dirigiram às cidades, de maneira equivalente à acumulação extensiva capitalista.

De acordo com Mei Zhang, a partir da década de 1980 - após a Reforma, portanto - o afrouxamento do sistema hukou levou milhões de camponeses a se deslocarem em um intenso movimento de migração. O principal fator que motivou

\footnotetext{
${ }^{325}$ TANG, Zongli (Org.). China's urbanization and socioeconomic impact. Estados Unidos: Springer, 2017. p. 112.

${ }^{326}$ Ibidem.

${ }^{327}$ ARRIGHI, Giovanni. Adam Smith em Pequim. São Paulo: Boitempo, 2008. p. 366.

${ }^{328}$ DANG, Guoying. 30 years of China's rural reform. In: CHINA, Institute for Reform and Development. 30 years of China's Reform. Beijing: Foreign Languages Press, 2008. p. 116-118.
} 
esse êxodo era força de trabalho sobressalente no campo em decorrência do aumento da produtividade na agricultura ${ }^{329}$.

Acontece que essa flexibilização era apenas uma concessão tácita do Estado à mobilidade dos trabalhadores, deixando-os à margem do Bem-Estar social. Em números, a migração foi muito significativa e sustentou o desenvolvimento econômico chinês, caracterizando seu processo de urbanização como um genuíno como um processo de assalariamento e, portanto, de acumulação extensiva.

Esquematicamente, esse processo pode ser descrito em três fases. A primeira fase marcou os anos 1980 com migrações locais, estimuladas especialmente pela criação das chamadas Zonas Especiais de Desenvolvimento (voltadas á produção industrial para exportação), em que o número de trabalhadores migrantes saltou de 2 milhões para 30 milhões entre 1980 e 1989. A segunda, muito mais intensa, caracterizou-se pelos deslocamentos interregionais da década de 1990, com que a população de trabalhadores migrantes atingiu a marca de 100 milhões de pessoas nessa condição, crescendo a uma taxa de 15\% ao ano. A partir dos anos 2000 essa taxa caiu a menos da metade, embora o aumento da população migrante tenha continuado ao incremento de quase 7 milhões de pessoas por ano, contabilizando um total de 230 milhões em $2009^{330}$.

Isso significa um número de trabalhadores em uma condição incompleta de cidadania - sem acesso a maior parte dos serviços públicos - maior do que o total da população brasileira. Apesar de trabalhar e habitar em cidades, os trabalhadores migrantes não tiveram seu registro hukou alterado de rural para urbano e, por isso, estão alheios à proteção do Estado em sua reprodução, que, cabe dizer, não pode ser viabilizada pelo mercado. Isso acarretou uma dura condição de vida a esses trabalhadores, envolvendo ambientes de trabalho inseguros e insalubres, atrasos em pagamento de salários, ausência de seguridade social - aposentadoria ou assistência

\footnotetext{
${ }^{329}$ ZHANG, Mei. China's poor regions. Londres: Routledge, 2003. p. 34.

${ }^{330}$ CHINA DEVELOPMENT RESEARCH FOUNDATION. Op. Cit., 2013. p. 34-35.
} 
a acidentes -, habitações precárias, educação infantil inadequada e difícil acesso à atenção médica ${ }^{331}$.

De acordo com Michel Aglietta e Guo Bai, o período de 1994 a 2008 foi marcado, na China, por um rápido crescimento da produção, acompanhado, porém, da estagnação dos salários. A gigantesca produção não pode, por isso, ser assimilada pela demanda doméstica e as desigualdades sociais se agravaram. Para os autores, isso constitui os limites do crescimento extensivo na China e impõe a necessidade de um modelo mais equilibrado do ponto de vista do Bem-Estar social ${ }^{332}$.

Há certa unanimidade no entendimento que questão central da economia chinesa atualmente é a superação de uma dinâmica que cresce em detrimento da reprodução dos trabalhadores migrantes e que apresenta claros sinais de esgotamento. Em outras palavras, nos termos aplicados pelo próprio governo chinês, trata-se de superar um regime extensivo de desenvolvimento. No cerne das ações práticas dessa preocupação está a estratégia em lidar com a urbanização e, especificamente, com a reprodução da força de trabalho.

Segundo Lin Ye, A economia e a urbanização chinesa dividem-se em dois momentos, o primeiro que vai da reforma de 1978 ao começo da década de 2000, e o segundo que segue desde então. O primeiro estágio caracterizou-se por uma indústria de exportação instalada na zona costeira do país, cujo processo de ocupação urbana por migrantes com pouquíssimos direitos constituiu a fonte de mão-de-obra barata de que o crescimento econômico se beneficiou. Já o segundo estágio marca uma reorientação da economia para o consumo interno, a transformação da indústria no sentido de tornar-se menos intensiva em trabalho, o foco no Bem-Estar e na preocupação com os trabalhadores, além de uma urbanização direcionada à ocupação

\footnotetext{
331 Ibidem. p. 36.

${ }^{332}$ AGLIETTA, Michel; GUO, Bai. La voie Chinoise. Paris: Odile Jacob, 2012. p. 5-12.
} 
do interior, fato que a rede de trens de alta velocidade ilustra com suas quatro linhas norte-sul e as quatro leste-oeste que atravessam território da China ${ }^{333}$.

Penlin Li argumenta que o tratamento da urbanização, ao lado da industrialização, constitui a principal força no direcionamento do desenvolvimento chinês, em sua nova fase de crescimento. Tal fase caracteriza-se pelo retorno decrescente dos investimentos, aumento dos custos do trabalho e consideráveis transformações na oferta e demanda do mercado de trabalho ${ }^{334}$. Isto é, o contingente de trabalhadores migrantes tende a diminuir com a evolução da urbanização, o que diminui a taxa de excedente acumulado em função de sua incorporação e sua reprodução torna-se, de tal modo, imprescindível, o que representa o aumento de seus "custos".

Para Qiang Li, o problema fundamental no tratamento da urbanização chinesa é a transformação do "sistema dual" que separa o status da população trabalhadora. Excluindo boa parte dessa população dos serviços e infraestruturas do Estado - ou seja, relegando sua reprodução -, o sistema desencadeou, com a migração em massa, sérios problemas ambientais, expansão ineficiente da mancha urbana, baixa produtividade e desigualdade social ${ }^{335}$.

É a essa problemática que se endereça a Nova Estratégia de Urbanização da China (NEU). Esboçada nos documentos oficiais desde o $12^{\circ}$ Plano Qüinqüenal, a NEU estipula que, até 2030, 400 milhões de trabalhadores migrantes deverão se estabelecer como residentes definitivos nas cidades, com acesso completo aos mesmos direitos dos trabalhadores com registro urbano, como saúde, educação e habitação ${ }^{336}$.

Segundo a Fundação de Pesquisa para o Desenvolvimento Chinês, esse direcionamento encaminha-se através de 7 eixos. Trata-se (1) da distribuição da

\footnotetext{
${ }^{333}$ YE, Lin. Urbanization and urban governance in China. Nova York: Palgrave, 2018. p. 80-85.

${ }^{334} \mathrm{LI}$, Penlin. Urbanization and its impact in contemporary China. Singapura: Springer, 2019. p. 1-2.

${ }^{335} \mathrm{LI}$, Qiang. China's development under a differential urbanization model. Singapura: Springer, 2020. p. 15.

${ }^{336}$ CHINA DEVELOPMENT RESEARCH FOUNDATION. Op. Cit., 2013. p. 3.
} 
urbanização conforme uma configuração espacial que se adéqüe à capacidade de suporte de cada região; (2) do foco no adensamento de núcleos urbanos, evitando o espraiamento das aglomerações; (3) da coordenação da urbanização com a política de desenvolvimento industrial e de distribuição territorial de empregos; (4) do aperfeiçoamento na provisão de serviços públicos; (5) do processo sustentável para a construção e financiamento da infraestrutura urbana; (6) da preocupação ambiental no desenvolvimento urbano e (7) da abordagem inovadora na administração da urbanização e na governança das cidades ${ }^{337}$.

Especificamente quanto à provisão de serviços públicos, o conceito inclui tanto infraestruturas físicas quanto serviços propriamente ditos. Seu modelo de disponibilização deve orientar-se pela disponibilização direta pelo Estado em relação a serviços e infraestruturas de difícil precificação, ao passo que o restante poderá assumir a forma de atividades privadas licenciadas ou orientadas pelo mercado, desde que submetidas à estrita regulação e, sobretudo, condicionadas ao interesse público ${ }^{338}$. $\mathrm{Na}$ China, o financiamento para o desenvolvimento urbano concentra-se em três fontes. A primeira, representando em torno de $32 \%$, vem de taxas cobradas localmente sobre operações imobiliárias e da negociação de títulos fundiários. A segunda vem de empréstimos bancários e constitui $29 \%$ do total. A terceira, $28 \%$, deriva de receitas de empresas locais ${ }^{339}$.

Tal modelo de financiamento, contudo, apresenta riscos e projeta-se sua mudança. Em primeiro lugar, o financiamento de operações imobiliárias e fundiárias compromete extensões esgotáveis de terra e as submete às oscilações do sistema financeiro. Em segundo lugar, essas mesmas oscilações são a ameaça intrínseca dos financiamentos por agências financeiras (bancos). Paradoxalmente, porém, recomenda-se o deslocamento para fontes próximas dos chamados mecanismos de mercado, como a venda de títulos públicos, as Parcerias Público Privado, o princípio

\footnotetext{
337 Ibidem.

338 Ibidem. p. 199.

${ }^{339}$ Ibidem. p. 203.
} 
do usuário-pagador e o financiamento por projetos ${ }^{340}$. Imagina-se, talvez, que por meio desses mecanismos e da típica preponderância do Estado chinês na regulação da economia possa-se garantir fontes mais estáveis e sustentáveis em longo prazo.

Além disso, prescreve-se um balanceamento entre expansão e manutenção nos investimentos voltados aos serviços públicos. Apesar das vultosas quantias investidas na expansão de serviços, pouco mais de $10 \%$ desses valores foram dedicadas à sua manutenção, inexpressividade que já se manifesta na intensificação de acidentes causados por ausência de manutenção ${ }^{341}$.

$\mathrm{Na}$ verdade, o intenso investimento na construção do novo ambiente sugere que o espaço urbano na China é uma tábula rasa, ou que a dualidade de seu território existe apenas entre campo e cidade. Isso é um equívoco. Embora não se possa falar em favelização na China, seu processo de urbanização caracterizou as cidades chinesas por uma estrutura urbana muito desigual. Trata-se, como descreve Houkai Wei, de "uma floresta de arranha céus em certas áreas, e um mar de habitações precárias e de baixa densidade em outras" ${ }^{342}$.

São bairros muito pobres e com péssimas instalações (shanty towns) ou pequenas e envelhecidas vilas que abrigam uma grande parcela da população, coexistindo entre espaços de modernização. Em grandes cidades como Xangai ou Pequim, como relata Lucimara Flávio dos Reis, essas vilas consistem em conjuntos arquitetônicos antigos, com ruas estreitas e edificações de baixo gabarito, que, durante principalmente a década de 1990, receberam grande número de pessoas e se caracterizaram como espaços de extrema precariedade ${ }^{343}$.

Para Wei, sem amplos melhoramentos, essas áreas devem transforma-se em favelas em curto espaço de tempo. E sua dimensão não é desprezível. De 2008 a

\footnotetext{
340 Ibidem. p. 204

341 Ibidem. p. 203.

${ }^{342}$ WEI, Houkai. Urbanization in China. Singapura: Springer, 2019. p. 192.

${ }^{343}$ REIS, Lucimara Flávio. Obsolescência e renovação do uso do solo nos centros das grandes cidades e o processo de acumulação capitalista. Tese de Doutoramento. Universidade de São Paulo, Faculdade de Arquitetura e urbanismo. 2015. p. 174
} 
2012, mais de 12 milhões de casas foram construídas em assentamentos precários em todo o país. Muitas são produtos da autoconstrução e do improviso dos trabalhadores. Em 2013, uma política específica do Estado lançou o objetivo de reconstruir mais de 10 milhões de casas em assentamentos precários até 2017 . Essa reconstrução, entretanto, envolve muitas dificuldades, que passam pelo aprimoramento da transparência no processo de desapropriação, do método de precificação das compensações e nos mecanismo de realocação e reassentamento ${ }^{344}$.

Muito dessa problemática ainda está associada ao alargamento da mancha urbana das grandes cidades. Desencadeado pela forte polarização industrial dos grandes centros em combinação com as forças de mercado, o espraiamento urbano tem causado sérios problemas à China, como a super população de determinadas áreas, o congestionamento, a diminuição e desequilíbrio das áreas de habitação, a poluição, a escassez de recursos e serviços e a intensificação da desigualdade social. Entre as principais medidas adotadas para lidar com a situação já consolidada é a expansão da capacidade de suporte dessas áreas, o que significa, principalmente, a extensão e o aprimoramento das redes de transporte público, tornando-as mais eficientes, confortáveis, acessíveis e sustentáveis ${ }^{345}$.

Enfim, apesar das inúmeras diferenças com o Brasil, a realidade urbana da China ainda apresenta alguns aspectos comparáveis com as características e problemas das cidades brasileiras. O mais importante é que sua agenda no encaminhamento dessas questões responde a uma mesma conjuntura material a que está submetido o Brasil: a crise do estágio extensivo de acumulação. Nesse cotejamento possível, são claras as lições que podem ser depreendidas para a direção do desenvolvimento brasileiro. Trata-se, em resumo, de uma visão de longo prazo, pragmática e com foco na materialidade da economia, explicitamente orientada à

\footnotetext{
${ }^{344}$ WEI, Houkai. Op. Cit., 2019. p. 193.

${ }^{345}$ Ibidem. p. 197-199.
} 
necessidade da intensificação das forças produtivas, especialmente à necessidade da elevação do nível das condições de reprodução da força de trabalho.

Mas há ainda um ponto relevante a ser considerado. Se, na solução desse impasse, Brasil e China permanecerão como Estados isolados seguindo suas trajetórias e evoluções particulares, seu resultado implicará um efeito comum. A elevação do consumo e da reprodução dos trabalhadores urbanos na China, no Brasil e, eventualmente, no restante do mundo - como indicam as progressivas taxas da urbanização mundial -, encontrará algum tipo de limite na capacidade de suporte natural dos recursos globais.

Para Csaba Deák, isso significa não apenas uma crise do capitalismo, mas da própria reprodução ampliada na terra, fator inédito em toda história humana e que qualquer modelo de desenvolvimento precisará enfrentar. O tão evocado termo "sustentabilidade" encontra seu real conteúdo, o longo-prazo ${ }^{346}$.

Pela sua própria natureza, a preocupação com o longo-prazo implica centralização e planejamento. Tais elementos certamente não podem ser encontrados no sistema de mercado, nem mesmo em um sistema de Estados de ações isoladas, guiadas pelos dificilmente definíveis interesses nacionais. Assim, é possível que estejam aí os rudimentos da dialética social que ora se descortina.

Isso, porém, não pode ser reduzido a um determinismo ambiental, do tipo malthusiano. Em um mundo cada vez mais urbano, os imperativos da reprodução social, em especial da força de trabalho, seguirão centrais na forma como se esculpem as sociedades. Sem isso, a crise da reprodução ampliada não é mais do que um ajuste metabólico, e o que resta é declínio.

\footnotetext{
${ }^{346}$ DEÁK, Csaba. Em busca das categorias de produção do espaço. São Paulo: Annablume, 2016. p. 100128.
} 


\section{CONSIDERAÇÕES FINAIS}

\subsection{Conclusão}

A preocupação fundamental deste trabalho foi estabelecer um princípio de mediação que possibilitasse mostrar o alcance teórico e os desdobramentos da dialética do mercado e do Estado. Isso levou a uma leitura do conteúdo e da evolução de diversos aspectos da reprodução social, tendo a reprodução da força de trabalho como elemento central.

Mais precisamente, defendeu-se ao longo destas páginas que a constante elevação do nível da reprodução da força de trabalho é uma condição sine qua non do aumento da produtividade e que, por isso, pauta, em última instância, a transição da acumulação extensiva à acumulação intensiva. Como o mercado - postulado como âmbito precípuo de regulação no capitalismo - é incapaz de promover essa elevação, o Estado, ao fazê-lo expande paulatinamente sua participação na produção social e nega, com isso, o mercado, constituindo, dessa forma, uma dialética.

A ação do Estado consiste na produção de valores de uso enquanto tais, na forma de infraestruturas, e se contrapõe ao mercado, que produz valores de uso por seu valor de troca, isto é, na forma de mercadorias. O antagonismo dialético, nesse caso, não repousa apenas na simples oposição entre forma-mercadoria e infraestrutura, entre mercado e Estado, mas, essencialmente, no movimento entre ambos, no imperativo que propulsiona o crescimento de um (Estado) sobre outro (mercado).

No argumento exposto, esse imperativo dinâmico reside, principalmente, na reprodução da força de trabalho. Percebê-lo assim evidencia o elo entre as categorias mais amplas da economia política e a realidade palpável do tecido social. Essa é a essência do estudo da urbanização e do exercício do planejamento urbano, campo a que mais especificamente se direciona as conclusões práticas deste ensaio. 
Como algo particular à ao funcionamento capitalista, a dialética do mercado e do Estado e a urbanização tem um tempo histórico específico. No caso europeu, remontam à baixa idade média e se apresentam em crise na atualidade. Especificamente sobre essa discussão procurou-se explicitar, em primeiro lugar, como a urbanização é um processo que corresponde à acumulação extensiva, isto é, ao processo de assalariamento.

Nas palavras de Csaba Deák, "a urbanização é o crescimento do proletariado". Uma vez que nesse processo as formas capitalistas crescem sobre outras formas sociais, e em detrimento dessas, a acumulação extensiva constitui, ainda nas palavras de Deák, um "saque" contra essas mesmas formas. O que se sustentou aqui é que isso significa a não reprodução da força de trabalho, que é incorporada pela sociedade capitalista em sua fase de acumulação extensiva. Essa não reprodução é patente na precariedade do ambiente urbano em tal fase do capitalismo.

Em segundo lugar, buscou-se mostrar como a exaustão do processo de assalariamento e, assim, da própria acumulação extensiva e da urbanização, demandou o aparelhamento das cidades, com foco na elevação do nível das condições de reprodução da força de trabalho. Sem a possibilidade de expandir o excedente da produção pela adição de forças produtivas, como no estágio precedente, tornou-se premente a intensificação das forças que já haviam sido englobadas pela dinâmica capitalista, o que pôs as sociedades de capitalismo avançado em um novo estágio de acumulação, de acumulação intensiva.

Que entendimento mais óbvio essa intensificação poderia representar se não a elevação da produtividade do trabalho? E, nesse sentido, para a viabilização desse crescimento da produtividade, o que mais sensível poderia ser se não a preocupação com as condições de reprodução da força de trabalho?

No ambiente urbano, essa preocupação tem inúmeras dimensões. O cuidado com a infância, com a saúde, com a educação, habitações saudáveis e seguras, espaços adequados para lazer, deslocamentos confortáveis, eficientes e que poupam 
tempo para o trabalho, para o estudo, para o convívio íntimo e até para o consumo, são todos exemplos do que integra a ação pela elevação do nível de reprodução da força de trabalho.

Esses exemplos compõem o escopo específico da atuação do Estado no encaminhamento das questões urbanas, constituem o próprio objeto do planejamento urbano. Na prática, no entanto, poucas vezes a reprodução dos trabalhadores e a produtividade do trabalho estiveram na base metodológica do planejamento - muito menos explícita e conscientemente. Ou seja, o planejamento urbano carece de critérios e objetivos que transcendam seu enquadramento técnico imediato e que o relacionem a sua verdadeira função na reprodução social.

O reconhecimento formal desse teor das questões urbanas abre caminho para que sua discussão seja feita no âmbito da racionalidade econômica, como algo necessário à manutenção da sociedade como um todo. Na possível continuidade dessa pesquisa, isso aponta para a exploração de procedimentos de análise que agreguem a reprodução da força de trabalho e o conseqüente aumento de produtividade no "cálculo de benefícios" da implantação de infraestruturas físicas e de equipamentos urbanos.

Efetivamente, qual é a magnitude do impacto dessas medidas sobre a geração do excedente social? A resposta a essa pergunta está além do escopo desta tese, mas não faltam elementos a sua abordagem, que poderia orientar o método do planejamento urbano de modo a realçar o liame entre a técnica, a realidade cotidiana e a das grandes estruturas socioeconômicas.

A atuação do Estado, naturalmente, condiciona-se à maneira peculiar de existência de cada formação social, o que não é diferente com sua ação sobre o urbano. A hipótese levantada nesta reflexão é de que a reprodução da força de trabalho constitui elemento fundamental da reprodução social e, assim, das formações sociais, inclusive em seu âmbito histórico, na moldura de cada modo de produção. 
Althusser divide a reprodução social em dois componentes. Trata-se da reprodução das relações de produção e da reprodução das forças produtivas. A primeira é assegurada pela superestrutura política e ideológica, que generaliza e consolida as relações de produção. A segunda está subdivida na reprodução dos meios de produção e na reprodução da força de trabalho.

Como agente primário da produção, a força de trabalho está na base do constructo social. Qualquer alteração no modo como é reproduzida a força de trabalho põe em movimento todo o arranjo social, como um princípio motor de sua dialética.

Tal interpretação foi o que se procurou experimentar em uma breve apreciação do processo histórico da Antiguidade e do feudalismo europeu. Baseada no trabalho escravo, a sociedade antiga não reproduzia sua força de trabalho e, por isso, lançava mão da guerra, não apenas como expediente de expansão, mas, sobretudo, de reprodução. Quando essa expansão encontrou limites, o declínio do organismo central do Estado imperial foi inevitável e foi preciso achar um meio para a reprodução dos trabalhadores.

Tal aconteceu mediante a posse da terra, de modo que escravos transformaram-se em servos camponeses, produzindo para seu próprio sustento e o de seus senhores. Assim, a produção assentou-se em unidades isoladas que dependiam mais da capacidade dos senhores em manter seus domínios do que da agência de um poder central. Nasceu, no âmago da Antiguidade, portanto, a sociedade feudal. Essa, por sua vez, também suscitou seus próprios antagonismos internos, alimentando um movimento de transição.

Seja pelo desenvolvimento técnico ou pelo descompasso entre produção e consumo de subsistência, a sociedade feudal expandiu paulatinamente o excedente comercializável. Esse excedente cresceu sobre as formas camponeses de produção para subsistência e, com isso, atingiu a maneira como se reproduzia a força de trabalho, o que implicou a invasão, por assim dizer, do mercado na esfera da produção, transformando os itens de subsistência, assim como, o próprio trabalho em mercadoria. 
Com isso chegou-se ao capitalismo, em uma relação de produção em que trabalhadores, como em um sistema de mercado, trocam trabalho por salário, e com o qual adquirem, no mercado, seu sustento. Conforme explanado, essa relação é, na realidade, insuficiente em prover tal sustento, e o Estado é progressivamente mobilizado como uma instância de regulação social, e sendo antagônico ao mercado, põe em movimento a dialética Mercado/Estado.

Nessa discussão, a evolução dos modos de produção é abordada com base em uma leitura dos imperativos da reprodução da força de trabalho. De maneira análoga, essa mesma base enseja a análise das nuances entre as formações sociais contemporâneas, em um plano comum de cotejamento.

Isso é o que se tentou com o estudo da reprodução social no Brasil e seu contraste com a China. A maneira específica da reprodução da força de trabalho - ou melhor, de sua não reprodução - é elemento marcante da evolução material da sociedade brasileira. No Brasil, a reprodução dos trabalhadores nunca foi uma preocupação preeminente, o que ilustra os quase quatro séculos de escravidão, a imigração como uma tentativa de continuidade desse mecanismo e a precariedade do cotidiano brasileiro durante todo o século XX e até a atualidade.

A incorporação de força de trabalho não reproduzida é o elo de longa duração da história brasileira e a impossibilidade de continuá-la é o que impõe sua transformação. No período colonial a não reprodução está inscrita na escravidão. Após 1850, faz parte da atípica acumulação extensiva do capitalismo brasileiro, que, como interpreta Csaba Deák, constitui uma acumulação entravada, com a aguda precariedade das condições de reprodução da força de trabalho.

Com o esgotamento da acumulação extensiva, correspondente à virtual completa urbanização do Brasil em fins do século $X X$, a intensificação das forças produtivas passa a ser o único meio de expandir a geração de excedente. Isso estabelece um limite material à continuidade da acumulação entravada e faz da 
reprodução da força de trabalho algo central em seu encaminhamento, que, vale dizer, permanece, atualmente, suspenso na crise do capitalismo brasileiro.

A China, apesar de todas as suas peculiaridades, atravessa momento histórico semelhante. No que toca seu estágio de desenvolvimento histórico e reconhecidamente em seus os próprios discursos oficiais, a sociedade chinesa passa de um desenvolvimento extensivo a um desenvolvimento intensivo. Tal passagem manifesta-se no avanço da urbanização e envolve a reorientação da economia à elevação do consumo interno e à correspondente expansão de direitos sociais, bem como, à reforma de seu sistema de seguridade social - o chamado sistema hukou. É possível dizer: essa mudança põe a reprodução da força de trabalho no cerne da nova fase da Reforma do Estado chinês.

O fato de a China alcançar esse momento em certa simultaneidade com o Brasil, torna a comparação de ambos algo possível e pertinente. Embora existam grandes diferenças entre ambos os países, a substância e a profundidade dessa transformação aproximam suas agendas. Suas escolhas pelo desenvolvimento requerem - ou requereriam, no caso brasileiro -, necessariamente, a elevação do nível das condições da reprodução da força de trabalho e a maneira específica como cada um dos Estados a realizam - ou não - serve de exemplo a outro.

Dentro da circunscrição crítica do questionamento acerca da reprodução da força de trabalho, qualquer comparação nesse sentido deixa de ser um despropósito. O desafio material que se apresenta à China, guardadas proporções, é o mesmo que o impasse da crise da acumulação entravada impõe ao Brasil. Entretanto, somente um estudo que está além da amplitude atingida por esta tese poderá explorar os desdobramentos e os pormenores dessa comparação.

Por fim, cabe o comentário sobre o que acima se denominou circunscrição crítica. Em grande medida, o apelo à noção de reprodução da força de trabalho visou contornar a dificuldade desta pesquisa em abarcar a totalidade do constructo social em uma interpretação dialética da transição entre os estágios de acumulação do 
capitalismo, assim como, entre as "bordas" de sua gênese e de sua crise e também entre suas variações no espaço, isto é, entre distintas formações sociais.

A categoria reprodução, como proposta por Althusser e Balibar, cumpre aqui função elementar. Diferentemente das categorias de modo de produção e das chamadas categorias intermediárias da abordagem regulacionista, que se prestam a excelente esquematização - a dizer, pelo meio, com a concepção de predominância -, a idéia de reprodução trabalha as bordas, em que a transformação - primeiro de quantidade e depois de qualidade - esmaece os limites dessa mesma predominância. A reprodução está, portanto, na essência do estudo da transição, das variações espaciais e da própria dialética.

Neste estudo, reduzir a reprodução social à análise de um de seus aspectos a reprodução da força de trabalho - resulta do obstáculo encontrado em sua concepção como totalidade, como concreto. A abordagem do concreto da realidade pelo pensamento - como já explicado por Marx - só é possível por meio de abstrações. O pensamento é capaz de retirar da realidade os fios (aspectos), mas não o tecido como um todo (totalidade social). Nesse caso, continua Marx, o concreto precisa ser reconstituído no pensamento, tornando-se, assim, o que chama de concreto-no-pensamento.

Para alguns autores, entretanto, como Barry Hindess e Paul Hirst, essa tarefa não é algo trivial. Chega-se mesmo a refutar sua possibilidade, a possibilidade do concreto-no-pensamento. Ao invés disso, esses autores procuram em certos aspectos e, sobretudo, no conceito de reprodução, elementos que permitam extrair conclusões sobre o funcionamento e a dialética do processo social.

De certa maneira, essa é a linha de abordagem desta tese. Busca-se na reprodução da força de trabalho um princípio de leitura e argumentação que oportunize a análise da dialética social e de suas nuances. Certamente, trata-se de uma análise parcial (não total), e, por isso, incompleta. 
Não é uma tentativa de teorizar a determinação de um aspecto sobre a totalidade social, como se diz, de colocar o carro à frente dos bois. Consiste apenas no reconhecimento de uma dificuldade na lida com o concreto social e de que, apesar dela, conclusões sobre esse concreto são possíveis.

Por tal motivo, recorreu-se ao enfoque da reprodução da força de trabalho. É o enfoque de uma inevitabilidade material que acompanha a estruturação de qualquer sociedade e é particularmente útil se considerada uma última dificuldade: o fato de que a transformação social transforma também as categorias e elementos de análise. Nesse sentido, mantê-los simples, palpáveis e abrangentes pode munir a teoria de alcance e profundidade, mas isso, talvez, implique abrir mão de abarcar no pensamento, de uma só vez, a totalidade.

Apesar de tudo, há a intuição de que essa limitação não deva constituir um embargo à busca dessa totalidade. Sobretudo, não deve constituir embargo à possibilidade do exercício de reformulação consciente da sociedade como um todo, de maneira concreta e no pensamento, portanto. Trata-se de utopia e também de imaginar algo capaz de guardar no pensamento o concreto. Essa discussão constitui, a seguir, o arremate deste texto.. 


\subsection{A necessidade de utopia}

Por todas as questões apontadas neste trabalho, a utopia é uma necessidade. A utopia é, na crise que enreda a sociedade contemporânea, uma maneira de explorar caminhos, de perceber, pragmaticamente, insuficiências, de expressar anseios; é, e sempre foi, a chance de resgatar algum protagonismo da coletividade frente aos imperativos, implacáveis, que conduziram a história.

Fora isso - que não é pouco -, a utopia também é um meio de conceber a concretude do processo social no pensamento. Por sua indissociável relação com capacidades intelectuais que vão além da racionalidade formalista e, principalmente, que se consubstanciam à arte, a utopia escapa às armadilhas do método e transcende as abstrações - como as entende Marx - que medeiam o concreto real e o concretono-pensamento.

Precisamente sobre o termo "concreto" é que Ernst Bloch divisa os contornos da verdadeira utopia. Autor da obra, possivelmente, de maior intensidade sobre o tema, Bloch, segundo Alysson Mascaro, tratou de eliminar a carga pejorativa da ideia de utopia, distinguindo-a como algo que chamou de "utopia concreta", em oposição ao que nomeou "utopia abstrata". Essa constitui uma simples projeção, em si, irrealizável. A outra é uma autêntica práxis, fundada na realidade presente e orientada para futuro ${ }^{347}$.

Para Bloch, a utopia concreta está ancorada na realidade como um processo. A realidade é um processo, em que as possibilidades estão abertas, e, por isso, não pode haver objeção à realização da utopia que se faz, dialeticamente, com um pé no "ser" e outro no "vir a ser". A objeção cabe, no entanto, às utopias abstratas, pois não estabelecem liame com esse processo que é a realidade ${ }^{348}$.

\footnotetext{
${ }^{347}$ MASCARO. Alysson Leandro. Utopia e Direito - Ernst Bloch e a ontologia jurídica da utopia. São Paulo: Quartier Latin, 2008. p. 113-115.

${ }^{348}$ BLOCH. Ernst. The principle of hope. Vol. I. Estados Unidos: MIT Press, 1996. p. 197.
} 
Apesar de estarem profundamente lastreados nas categorias marxistas, talvez não se possa dizer que os trabalhos de Bloch empregam os conceitos de concreto e abstrato em sentido semelhante ao delineado por Marx. Na verdade, de acordo com Ruth Levitas, rastrear a base epistemológica de tal distinção em Bloch é algo problemático $^{349}$.

Ainda assim, as concepções de Bloch podem se aproximar desse entendimento de Marx se considerado a particularidade do recurso pelo qual é construído o que chama de utopia concreta. Esse recurso consiste no sonho diurno, mecanismo psicológico que dá inspiração livre ao desejo de aprimorar, preservando o ego, o consciente, ao mesmo tempo em que o projeta para mundo, em direção a outros egos e tomando como veículo também qualquer forma artística ${ }^{350,351 \text { e } 352 .}$.

Certamente, isso não pode ser inscrito no âmbito da metodologia convencional, alicerçada em abstrações e, por suposto, objetiva - alheia ao sujeito. Ademais, aqui a arte parece ser a única via para a vazão de qualquer coisa similar à proposta de Bloch, o que, aliás, a crítica literária - em especial, marxista -, corrobora.

Na discussão do drama histórico e do romance histórico, George Lukács afirma que somente a arte pode representar mentalmente a totalidade da vida, ainda que de maneira relativa. Uma simples reflexão intelectual de fatos e leis da realidade objetiva precisa reconhecer essa relatividade, sob pena de pretender ser absoluta e ignorar sua incompletude, distorcendo e falsificando a realidade a que se refere. Isso é diferente com a arte. A arte, pela própria natureza de sua criação, tem a capacidade aguçada, segundo Lukács, nos gêneros da tragédia e do grande épico - de dar aparência real a essa relatividade ${ }^{353}$.

\footnotetext{
${ }^{349}$ LEVITAS, Ruth. Educated Hope: Ernst Bloch on abstract and concrete utopia. Utopian Studies. Estados Unidos. Vol. I, N. 2, p. 13-26. 1990.

${ }^{350}$ BLOCH. Ernst. Op. Cit. 1996. p. 86-92

${ }^{351}$ MASCARO. Alysson Leandro.. Op. Cit. 2008. p. 115-119

352 LEVITAS, Ruth. Op. Cit. 1990. p. 14.

353 LUKÁCS, George. The historical novel. Londres: Merlin Press, 1989. p. 91-92.
} 
Em um sentido talvez não muito distante ao dos ensaios de Lukács, pode-se citar o que Antonio Candido denomina redução estrutural. Por meio da redução estrutural, elementos a princípio não literários - o mundo e o ser - são internalizados na narrativa, de modo que podem ser identificados nela em sua essência, sem que isso, contudo, retire a independência da obra em relação à realidade na qual tem base $^{354}$.

De fato, a eficácia de um texto na comunicação de uma impressão de vitalidade e verossimilhança depende antes da concatenação cuidadosa de seus componentes do que da alusão ao exterior que o suscita. Por isso, o desafio da crítica literária, mais do que meramente indicar a presença desse fundo material na obra, é mostrar como ele é explorado pela narrativa ficcional ${ }^{355}$.

Em vista disso, a arte, nessa acepção, tem dupla importância. Em primeiro lugar, é um meio de representar todas as dimensões da realidade social. Em segundo, é também a única maneira à disposição de experimentar os desdobramentos das crises que se apresentam à atualidade, seja a crise da passagem da acumulação extensiva à intensiva, a transformação decorrente da dialética do mercado e do Estado ou os limites da capacidade de suporte planetária à própria reprodução ampliada, em qualquer uma de suas formas.

Para Csaba Deák, todos esses níveis de crises levantam a necessidade de utopias. Demandam a explosão de um gênero literário que supere as fantasias da ficção científica, substituindo o retrato episódico de milênios à frente por uma discussão da ordem social em um futuro não tão longínquo ${ }^{356}$. Ainda que a ficção

\footnotetext{
${ }^{354}$ CANDIDO, Antonio de Melo e Souza. O discurso e a cidade. Rio de Janeiro: Ouro sobre azul, 2004. p. 9-12. ${ }^{355}$ Ibidem.

${ }^{356}$ DEÁK, Csaba. The city in the Brazilian novel. In: CHARLEY, Jonathan (Org.). The Routledge companion on architecture, literature and the city. Nova York: Routledge, 2018. p. 228.
} 
científica contenha elementos de utopia, como observa Jonathan Charley ${ }^{357}$, é preciso que seja resgatado o teor crítico e o ideal transformador dessas propostas literárias.

Essa é a natureza da utopia. Morton, em estudo sobre a história da utopia na Inglaterra, mostra como ela reflete, exatamente como um espelho, a própria história inglesa e suas crises. Da "Cocanha", na baixa idade média, e da "Utopia" de Thomas More, no contexto pré-revolucionário, aos ensaios de William Morris, no período vitoriano, todas as utopias manifestavam aspirações, necessidades e algum grau de crítica social $^{358}$.

Além disso, seu conteúdo é essencialmente transformador. Para Karl Mannheim, o que caracteriza a utopia, e a distingue da ideologia, é - a primeira - estar imbuída de ideal transformador, do intuito de negar a realidade e de transcender sua existência $^{359}$. Já para Bloch esse impulso existe por conta da incompletude da realidade, expressa na necessidade, na carência e na fome, tanto em sentido físico como simbólico ${ }^{360}$.

Assim, a utopia deve compreender os expedientes para vencer as dificuldades conceituais pontuadas neste trabalho e dispor-se como proposta concreta para 0 futuro. Direcionar, aqui, o olhar sistemático à reprodução dos trabalhadores teve o objetivo de enxergar a substância tangível de um consistente arranjo teórico - a dizer, do materialismo dialético e, especificamente, da dialética do mercado e do Estado.

Em um exercício concreto, de utopia, esse aspecto permanecerá fundamental, porém sua abordagem enriquecerá em teor e estará imbricada à totalidade da reprodução social. Equivale à fome a que se refere Bloch e encaminha, assim, uma espécie de "consciência da necessidade".

\footnotetext{
${ }^{357}$ CHARLEY, Jonathan. The cold war finds a common home. In: CHARLEY, Jonathan (Org.). The Routledge companion on architecture, literature and the city. Nova York: Routledge, 2018. p. 153. 358 MORTON, Arthur Leslie. The English utopia. Disponível em:

https://www.marxists.org/archive/morton/1952/english-utopia/index.htm. Acesso em: 05-08-2020.

359 MANNHEIM, Karl. Ideology and utopia. Londres: Routledge \& Kegan Paul, 1954. p. 173-175.

${ }^{360}$ MASCARO. Alysson Leandro.. Op. Cit. 2008. p. 115-119
} 
$\mathrm{Na}$ máxima hegeliana e marxista, a consciência da necessidade é a propriedade característica da liberdade. No enunciado clássico, a liberdade é a consciência da necessidade ${ }^{361}$ e sua conceituação, concatenada ao argumento apresentado, pode ser posta face à ideia de autodeterminação. Afinal, é livre o que se autodetermina.

Mas se tomada ao sentido de "voluntária", essa ideia de autodeterminação e, consequentemente, de liberdade, só pode ser situada em uma esfera essencialmente coletiva e coordenada. Pois as partes, os indivíduos, adquirem existência concreta no todo. Sem tal compreensão, a autonomia humana é algo que a história relega ao campo do possível. Levá-la à prática exige outro tipo de consciência: concreta.

${ }^{361}$ ENGELS, Frederick. Anti-Duhring. In: Karl Marx and Frederick Engels: collected works. Vol. 25. Nova York: International Publishers, 1987. p. 105-106. 
Lista de referências

AGLIETTA, Michel. Fases da expansão capitalista nos Estados Unidos da América. Espaço \& Debates. Ano IX, n. 28. São Paulo, 1989.

Regulación y crisis do capitalismo. México: siglo XXI, 1976.

AGLIETTA, Michel; GUO, Bai. La voie Chinoise. Paris: Odile Jacob, 2012.

ALENCASTRO, Luiz Felipe. A pré-Revolução de 30. Novos Estudos Cebrap. N. 18, 17-21. São Paulo: Cebrap, 1987.

O trato dos viventes. São Paulo: Companhia das letras, 2000.

ALENCASTRO, Luiz Felipe; RENAUX, Maria Luiza. Caras e modos dos migrantes e imigrantes. In: ALENCASTRO, Luiz Felipe (Org.). História da vida privada no Brasil. Vol 2. São Paulo: Companhia das letras, 1997.

ALTHUSSER, Louis. BALIBAR, Etienne. Reading Capital. Londres: Verso, 1979.

ALTHUSSER, Louis. On the reproduction of capitalism: Ideology and Ideological State Apparatuses. Londres: Verso, 2014.

ALVES, Cintia de Souza. A tentativa de uma política de ordenamento territorial no Brasil. Tese de Doutoramento. Universidade de São Paulo, Faculdade de Arquitetura e urbanismo. 2017.

ANDERSON, Perry. Balanço do neoliberalismo. In: SADER, Emir; GENTILI, Pablo (Org.). Pós-neoliberalismo: as políticas sociais e o Estado democrático. Rio de Janeiro: Paz e Terra, 1995.

Passages from antiquity to feudalism. Londres: NLB, 1974.

ARANTES, Otília. Urbanismo em fim de linha. São Paulo: EDUSP, 1998.

ARISTÓTELES. A política. São Paulo: Lafonte, 2012.

ARIZA, Marília B. A. Crianças e Ventre Livre. In: SCHWARCZ, Lília Moritz; GOMES, Flávio dos Santos (Org,). Dicionário da escravidão e liberdade. São Paulo: Companhia das Letras, 2018.

ARRIGHI, Giovanni. Adam Smith em Pequim. São Paulo: Boitempo, 2008.

O longo século XX. Rio de Janeiro: Contraponto, 1996.

BARBOSA, Alexandre de Freitas. A formação do mercado de trabalho no Brasil. São Paulo: Alameda, 2008.

BARBOSA, Alexandre de Freitas. A formação do mercado de trabalho no Brasil. São Paulo: Alameda, 2008.

BARBOSA, Carlos Alberto Sampaio. A Revolução Mexicana. São Paulo: Unesp, 2010. 
BATTAGLIA, Luisa. Cadastros e registros fundiários: a institucionalização do descontrole sobre o espaço no Brasil. Tese (Doutorado) - Faculdade de Arquitetura e Urbanismo da universidade de São Paulo. São Paulo, 1995.

BENEVOLO, Leonardo. História da cidade. São Paulo: Perspectiva, 1993.

BIELSCHOWSKY, Ricardo. Pensamento econômico brasileiro: o ciclo ideológico do desenvolvimentismo. Rio de Janeiro: Contraponto, 2000.

BLOCH. Ernst. The principle of hope. Vol. I. Estados Unidos: MIT Press, $1996 .$.

BOIS, Guy. On the crisis of the Late Middle Ages. The Medieval History Journal. Vol. 1, 2. 311-321. 1998.

BOTTOMORE, Thomas. Dicionário do pensamento marxista. Rio de Janeiro: Zahar, 2001.

BOYER, Robert. A teoria da regulação: uma análise crítica. São Paulo: Nobel, 1990.

2009.

Teoria da regulação: os fundamentos. São Paulo: Estação Liberdade,

BRADLEY, Keith R. On the Roman slave supply and slavebreeding. Slavery et Abolition. Reino Unido. 8:1, 42-64. 2008.

BRANDÃO, Luiz Felipe. O Estado e o mercado no processo de produção do espaço em Alagoas. Maceió: Fapeal, 2018.

BRAUDEL, Fernand. Civilização material, economia e capitalismo: séculos XVXVIII. V. II, o jogo das trocas. São Paulo: Martins Fontes, 2009.

Civilização material, economia e capitalismo: séculos XV-XVIII. V. I, as $\overline{\text { estruturas }}$ do cotidiano. São Paulo: Martins Fontes, 2009.

BRENNER, Robert. Agrarian class structure and economic development. Past \& Present. Reino Unido. No. 70. 30-72. 1976.

BRUNT, Peter Astbury. Italian manpower - 225 B.C-14 A.D. Nova York: Oxford University Press, 1971.

BURAQUE DE HOLANDA, Sérgio et all. História Geral da Civilização Brasileira. Vol. I. Rio de Janeiro: Bertrand Brasil, 2007.

CAMPOS, Simoni Martinoli. O Estado brasileiro e o processo de produção do espaço no Acre. Tese de doutoramento. Universidade de São Paulo, Faculdade de Arquitetura e Urbanismo. 2005.

CANDIDO, Antonio de Melo e Souza. O discurso e a cidade. Rio de Janeiro: Ouro sobre azul, 2004.

CARDOSO, Ciro Flamarion. A Afro-América: a escravidão no Novo Mundo. São Paulo: Brasiliense, 1982. 
CARVALHO FRANCO, Maria Sylvia. Homens livres na ordem escravocrata. São Paulo: UNESP, 1997.

CARVALHO, José Murilo de. A construção da ordem e Teatro de sombras. Rio de Janeiro: Civilização Brasileira, 2008.

CASTEL, Robert. From manual workers to wage laborers. Nova Jersey: Transaction Publishers. 2003.

CHANG, Xiuze. China's mode of development. In: CHINA, Institute for Reform and Development. $\mathbf{3 0}$ years of China's Reform. Beijing: Foreign Languages Press, 2008.

CHARLEY, Jonathan. The cold war finds a commom home. In: CHARLEY, Jonathan (Org.). The Routledge companion on architecture, literature and the city. Nova York: Routledge, 2018.

CHINA DEVELOPMENT RESEARCH FOUNDATION. China's new urbanization strategy. Londres: Routledge, 2013.

COE, Paulo. São Paulo: “paraíso” dos grileiros. Sem dados de edição ou data.

COMTE. Augusto. A general view of positivism. Cap. III. 1848. Disponível em: https://archive.org/details/ageneralviewpos00comtgoog/page/n4. Acesso em: 21/01/2020.

COSTA E SILVA, Alberto. A manilha e o libambo. Rio de Janeiro: Nova Fronteira, 2011.

Um rio chamado Atlântico. Rio de Janeiro: Nova Fronteira, 2011.

COSTA, Emília Viotti da. Introdução ao estudo da emancipação política do Brasil. In: MOTA, Carlos Guilherme (Org.). Brasil em perspectiva. São Paulo: Difel, 1977.

Da Monarquia à República. 1998. São Paulo: Editora UNESP, 2007.

DANG, Guoying. 30 years of China's rural reform. In: CHINA, Institute for Reform and Development. $\mathbf{3 0}$ years of China's Reform. Beijing: Foreign Languages Press, 2008.

DE STE. CROIX, Geoffrey Ernst Maurice. The class struggle in the Ancient Greek World. Nova York: Cornell University Press, 1981.

DE VRIES, Jan. La urbanización de Europa - 1500-1800. Barcelona: Editorial Crítica, 1987.

DEÁK, Csaba. Acumulação entravada no Brasil e a crise dos anos 1980. In DEÁK, Csaba; SCHIFFER, Sueli (Org.). O processo de urbanização no brasil. São Paulo: Edusp, 2010. Annablume, 2016.

Em busca das categorias de produção do espaço. São Paulo:

Mercado e Estado (Verbete). Disponível em: http://www.fau.usp.br/docentes/depprojeto/c_deak/CD/4verb/estadoem/index.html. Acesso em: 18/01/2020. 
. O mercado e o Estado na organização espacial da produção capitalista. Espaço \& Debates. 28:18-31. São Paulo: Neru, 1989.

. O processo de urbanização no Brasil: falas e façanhas. In: DEÁK, Csaba; SCHIFFER, Sueli. O processo de urbanização no Brasil. São Paulo: EDUSP, 2010.

Rent theory and the pirce of urban land: spatial organization in a capitalist economy. Tese de Doutoramento, Universidade de Cambridge. 1985.

The city in the Brazilian novel. In: CHARLEY, Jonathan (Org.). The Routledge companion on architecture, literature and the city. Nova York: Routledge, 2018.

Inglaterra, 2001.

The Partido dos trabalhadores in São Paulo. 18:41-52. Soundings.

Verbete: Acumulação Entravada. Disponível em: http://www.usp.br/fau/docentes/depprojeto/c_deak/CD/4verb/acum-ent/index.html. Acesso em: 05/02/2020.

DEÁK, Csaba; SCHIFER, Sueli. The metropolis of an elite society. In SEGBERS, Klaus (Org.). The making of global city regions. Baltimore: John Hopkins University Press, 2007.

DOBB, Maurice. Studies in the development of capitalism. Londres: Routledge, 1946.

Uma réplica. In: SWEEZY, Paul et al. A transição do feudalismo para o capitalismo. Rio de Janeiro: Paz e terra, 1977.

DRENDEL, John et all. Crisis in the later middle ages: beyond the Postan-Duby paradigm. Bélgica: Brepols, 2015.

DUBY, Georges. Economía Rural y vida campesina en el occidente medieval. Barcelona: Ediciones Península, 1973.

ENGELS, Frederick. Anti-Duhring. In: Karl Marx and Frederick Engels: collected works. Vol. 25. Nova York: International Publishers, 1987.

The condition of the working class in England. Results. Disponível em: https://www.marxists.org/archive/marx/works/1845/condition-working-class/index.htm. Acesso em: 16/01/2020.

FAUSTO, Boris. História Concisa do Brasil. São Paulo: Edusp, 2008. História do Brasil. São Paulo: Companhia das Letras, 2011.

FERNANDES, Florestan. Capitalismo dependente e classes sociais na América Latina. São Paulo: Zahar, 1973.

FONSECA, Nuno. Notas de aula - AUP 5823 - Crítica à teoria da renda. FAU-USP. São Paulo, 2019. 
FRAGOSO, João Ribeiro. Modelos explicativos da economia escravista no Brasil. In: CARDOSO, Ciro Flamarion. Escravidão e abolição no Brasil: novas perspectivas. Rio de Janeiro: Zahar, 1988.

FRAGOSO, João. FLORENTINO, Manolo. O arcaísmo como projeto. Rio de Janeiro: Civilização Brasileira, 2001.

FREYRE, Gilberto. Casa-Grande e senzala. São Paulo: Global, 2003.

FURTADO, Celso. Formação econômica do Brasil. São Paulo: Companhia das Letras, 2007.

GELPI, Adriana. Rio Grande do Sul, processo de ocupação do território. Tese de doutoramento. Universidade de São Paulo, Faculdade de Arquitetura e Urbanismo. 2003.

GILBERT, Edmund W. Pioneer maps of health and disease in England. Geographical Journal. Vol. 124, n. 2. 172-183. 1958.

GORENDER, Jacob. O escravismo colonial. São Paulo: Fundação Perseu Abramo, 2016.

GRINBERG, Keila. Castigos físicos e legislação. In: SCHWARCZ, Lília Moritz; GOMES, Flávio dos Santos (Org,). Dicionário da escravidão e liberdade. São Paulo: Companhia das Letras, 2018.

GROSTEIN, Marta Dora. A cidade clandestina: ritos e mitos. Universidade de São Paulo, Faculdade de Arquitetura e Urbanismo. Tese de doutoramento. São Paulo, 1987.

HAGGARD, Robert. The persistence of victorian liberalism: the politics of social reformo f Britain - 1870-1900. Londres: Greenwood Press, 2001.

HARPER, Kyle. Slavery in the late Roman world - AD 275-425. Nova York: Cambridge University Press, 2011.

HARVEY, David. The condition of postmodernity. Oxford: Blackwell, 1990.

HILL, Christopher. The world turned upside down. Londres: Penguin, 1975.

HILTON, Rodney. A crisis of feudalism. Past \& Present. Reino Unido. No. 80. 3-19. 1978.

HILTON, Rodney. Introdução ao debate sobre a transição do feudalismo ao capitalismo. In: SWEEZY, Paul et al. A transição do feudalismo para o capitalismo. Rio de Janeiro: Paz e terra, 1977.

HINDESS, Barry. HIRST, Paul. Mode of production and social formation. Londres: Macmillan Press, 1977.

HOBSBAWM, Eric. A era dos extremos. São Paulo: Companhia das Letras, 1995.

The age of capital. Londres: Abacus, 1977.

HUBERMAN, Leo. Nós, o povo. São Paulo: Brasiliense, 1966. p. 177. 
HUGUENEY, Clodoaldo Filho. Para onde vai a China sob a quinta geração. Revista de Política Externa. Vol. 22, N. 2. São Paulo: Paz e Terra, 2013.

ITIKAWA, Luciana. Mulheres na periferia do urbanismo. Buenos Aires: CLACSO, 2015.

KARATAEV et al. História de las doctrinas econonomicas. México: Grijalbo, 1964.

KEYNES, John Maynard. A teoria geral do emprego, do juro e da moeda. São Paulo: Nova Cultural, 1985.

KOLB, Eberhard. The Weimar Republic. Londres: Routledge, 1990..

LEBRET, Louis Joseph. Manifesto por uma civilização solidária. São Paulo: Duas Cidades, 1962.

LEVITAS, Ruth. Educated Hope: Ernst Bloch on abstract and concrete utopia. Utopian Studies. Estados Unidos. Vol. I, N. 2, p. 13-26. 1990.

LEWIS, Arthur. Economic Development with unlimited supplies of labour. Manchester School, Vol. 22-2, 139-190 . 1954. Unlimited labour: further notes. Manchester School, Vol. 26-1, 1-31 . 1958.

LI, Penlin. Urbanization and its impact in contemporary China. Singapura: Springer, 2019.

LI, Qiang. China's development under a differential urbanization model. Singapura: Springer, 2020.

LIBÂNEO, Adriano Leonardi. Dialética da organização espacial: a metrópole de uma sociedade de elite. Tese de doutoramento. Universidade de São Paulo, Faculdade de Arquitetura e Urbanismo. 2013.

LIMA, Heitor Ferreira. História do pensamento econômico no Brasil. São Paulo: Editora Nacional, 1978.

LOEB, Roberto. Aspectos do planejamento territorial e urbano no Brasil. In: MINDLIN, Betty. Planejamento no Brasil. São Paulo: Perspectiva, 2003.

LUKÁCS, George. The historical novel. Londres: Merlin Press, 1989.

MACEDO, Roberto B. M. Plano Trienal de Desenvolvimento Econômico e Social (1963-1965). In: MINDLIN, Betty. Planejamento no Brasil. São Paulo: Perspectiva, 2003.

MADDISON, Angus. The world economy: a millennial perspective. Vol. I. Paris: OECD Publishing, 2006.

MANNHEIM, Karl. Ideology and utopia. Londres: Routledge \& Kegan Paul, 1954.

MARICATO, Ermínia. Metrópole, legislação e desigualdade. Estudos Avançados. 17 (48). São Paulo: IEA-USP, 2003. 
MARSHALL, Thomas. Citizenship and social class. In: MANZA, Jeff; SAUDER, Michael (Org.). Inequality and society. Nova York: W. W. Norton and Co., 2009.

MARTINS, José de Souza. O cativeiro da Terra. São Paulo: Contexto, 2017.

MARX, Karl. A contribution to the critique of political economy. Prefácio. Disponível em: https://www.marxists.org/archive/marx/works/1859/critique-poleconomy/preface.htm. Acesso em: 20/12/2019.

Capital. Londres: Penguin, 1990.

MARX, Karl. ENGELS, Friedrich. A ideologia alemã. São Paulo: Hucitec, 1989.

MASCARO, Alyson Leandro. Crise e golpe. São Paulo: Boitempo, 2018.

Estado e forma política. São Paulo: Boitempo, 2013.

. Utopia e Direito - Ernst Bloch e a ontologia jurídica da utopia. São

Paulo: Quartier Latin, 2008.

MATTOS, IImar Rohloff. O tempo Saquarema. São Paulo: Hucitec, 1987.

MAUTNER, Yvonne. A periferia como fronteira de expansão do capital. In DEÁK, Csaba; SCHIFFER, Sueli (Orgs.). O processo de urbanização no brasil. $1^{\text {a }}$ ed. 1999, $2^{\underline{a}}$ ed. São Paulo: Edusp, 2010.

MERRINGTON, John. A Cidade e o campo na transição para o capitalismo. In: SWEEZY, Paul et al. A transição do feudalismo para o capitalismo. Rio de Janeiro: Paz e terra, 1977.

MORE, Thomas. Utopia. Brasília: Editora UNB, 2004.

MORI, Klára Kaiser. A ideologia na constituição do espaço brasileiro. In DEÁK, Csaba; SCHIFFER, Sueli (Org.). O processo de urbanização no brasil. São Paulo: Edusp, 2010.

Brasil: urbanização e fronteiras. Tese de Doutoramento. Universidade de São Paulo, Faculdade de Arquitetura e urbanismo. 1996.

MORTON, Arthur Leslie. A história do povo inglês. Rio de Janeiro: Civilização Brasileira, 1970.

\section{The English utopia.}

Disponível em: https://www.marxists.org/archive/morton/1952/english-utopia/index.htm. Acesso em: 05-08-2020.

NOVAIS. Fernando. Portugal e Brasil na crise do antigo sistema colonial. São Paulo: Hucitec, 1989.

OLIVEIRA, Francisco de. Crítica à razão dualista e o ornitorrinco. São Paulo: Boitempo, 2013.

ONU. World Urbanization Prospects 2018. Disponível em: https://population.un.org/wup/. Acesso em: 13/01/2020. 
PADRÓS, Enrique Serra. Capitalismo, prosperidade e Estado de Bem-Estar social. In: AARÃO REIS FILHOI (Org.). O século XX: tempo das crises. Rio de Janeiro: Civilização Brasileira, 2003.

PIMENTA, Tânia Salgado. Doenças. In: SCHWARCZ, Lília Moritz; GOMES, Flávio dos Santos (Org,). Dicionário da escravidão e liberdade. São Paulo: Companhia das Letras, 2018.

PIRENNE, Henri. Medieval cities: their origins and the revival of trade. Princeton: Princeton University Press, 1946.

POLANYI, Karl. The Great Transformation. Boston: Beacon press, 2001.

POMAR, Wladimir. A revolução chinesa. São Paulo: Unesp, 2004.

O enigma chinês. São Paulo: Fundação Perseu Abramo, 2015.

POSTAN, Michael M. Essays on medieval agriculture and general problems of the medieval economy. Londres: Cambridge University Press, 1978.

The medieval economy and society. Londres: Penguin, 1975.

PRADO, Caio Jr. A imigração brasileira no passado e no futuro. In: A evolução política do Brasil e outros estudos. São Paulo: Editora brasiliense, 1953.

A revolução brasileira. São Paulo: Brasilense, 1966.

r. Formação do Brasil contemporâneo. São Paulo: Companhia das Letras,

2013.

Roteiro para a historiografia do Segundo Reinado (1840-1889). In: A evolução política do Brasil e outros estudos. São Paulo: Editora brasiliense, 1953.

REIS, Lucimara Flávio. Obsolescência e renovação do uso do solo nos centros das grandes cidades e o processo de acumulação capitalista. Tese de Doutoramento. Universidade de São Paulo, Faculdade de Arquitetura e urbanismo. 2015.

ROLL, Eric. A history of economic thought. Londres: Faber and Faber, 1965.

SADER, Emir. Constituinte, democracia e poder. In: Sader, Emir (ORG.). Constituinte e democracia no Brasil hoje. São Paulo: Brasiliense, 1985.

SCHIFFER, Sueli Ramos. A dinâmica urbana e socioeconômica da região metropolitana de São Paulo: 1970-1975. In: SCHIFFER, Sueli Ramos (Org.). Globalização e estrutura urbana. São Paulo: Hucitec, 2004.

SCHWARZ, Roberto. Ao vencedor as batatas. São Paulo: Duas Cidades/Editora 34, 2008.

SELIGER, Martin. The liberal politics of John Locke. Nova York: Frederick A. Praeger, 1969. 
SMITH, Adam. The Wealth of nations. Livro II, cap. 3. Disponível em: https://www.marxists.org/reference/archive/smith-adam/works/wealth-of-

nations/index.htm. Acesso em: 16/01/2020.

STEUART, James. Inquiry into the principles of political economy. Vol. I, Cap. X. Disponível em: https://www.marxists.org/reference/subject/economics/steuart/index.htm. Acesso em: 16/01/2020.

STEVENS, Courtaney Edward. Agriculture and rural life in the later Roman Empire. In: POSTAN, Michael M. Cambridge Economic History of Europe. Vol I - The agrarian life of the middle ages. Londres: Cambridge University Press, 1966.

SUTCLIFFE, Antony. Towards the planned city. Nova York: St. Martin, 1981.

SWEEZY, Paul. et all. A transição do feudalismo para o capitalismo. Rio de Janeiro: Paz e Terra, 1978.

. Uma Tréplica. In: SWEEZY, Paul et al. A transição do feudalismo para o capitalismo. Rio de Janeiro: Paz e terra, 1977.

TANG, Zongli (Org.). China's urbanization and socioeconomic impact. Estados Unidos: Springer, 2017.

VELHO, Otávio Guilherme. Capitalismo autoritário e campesinato. Rio de Janeiro/São Paulo: Difel, 1979.

WALLERSTEIN, Immanuel Maurice. The modern world system. Vol. I. Nova York: Academic Press, 1974.

WEI, Houkai. Urbanization in China. Singapura: Springer, 2019.

WHITTAKER, Charles R. Circe's pigs: from slavery to serfdom in the later Roman world. Slavery et Abolition. Reino Unido. 8:1, 88-122. 1987.

WINSTALEY, Gerrard. Digger pamphlet. Disponível em: http://www.diggers.org/diggers/declaration\%20from\%20the\%20poor\%20oppressed.ht m. Acesso em: 11/01/2020.

WOOD, Ellen Meiksins. Citzens to lords. Nova York: Verso, 2008.

The origin of capitalism. Nova York: Verso, 2002.

XI, Jinping. A Governança da China. Vol. I. Rio de Janeiro: Contraponto/Foreign Languages Press, 2019.

XIE, Chuntao (Org.). China through the ages. Vol II. Beijing: New World Press, 2009.

YE, Lin. Urbanization and urban governance in China. Nova York: Palgrave, 2018.

ZHANG, Mei. China's poor regions. Londres: Routledge, 2003. 


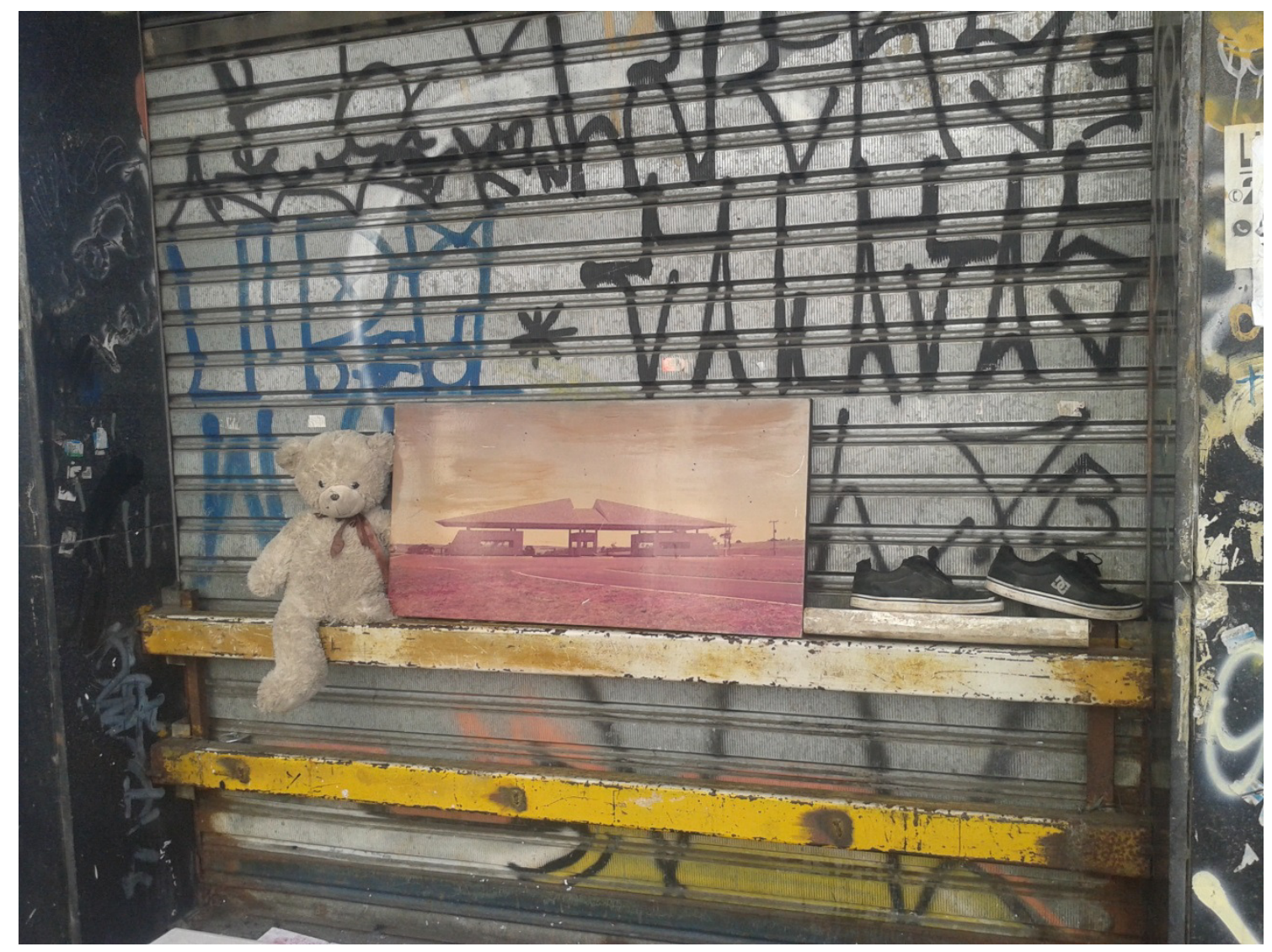

Imagem da capa:

Fotografia tirada pelo autor às proximidades da Rua General Osório. São Paulo, agosto de 2019. 


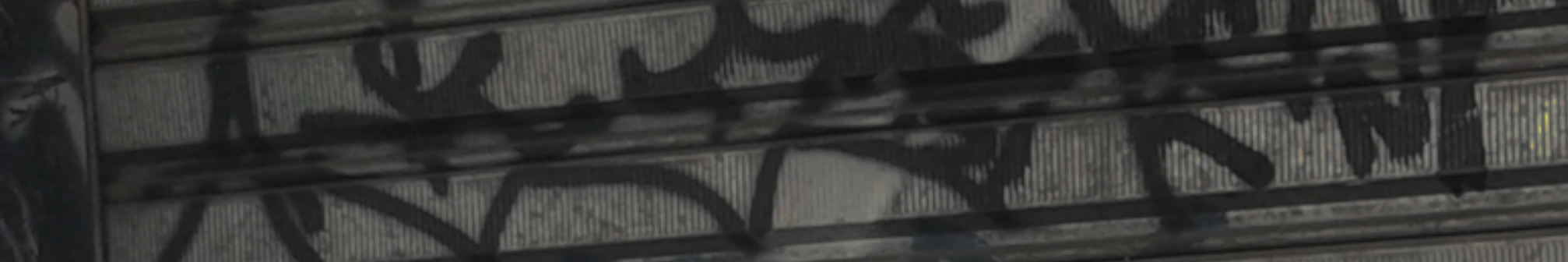

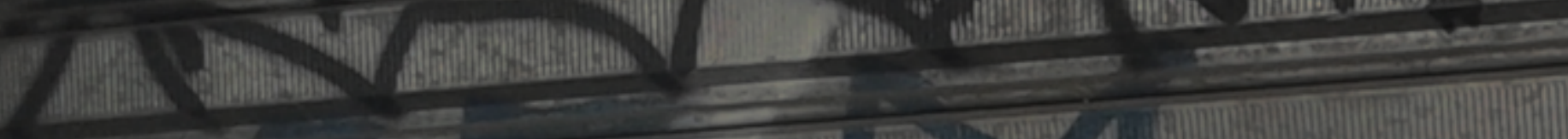
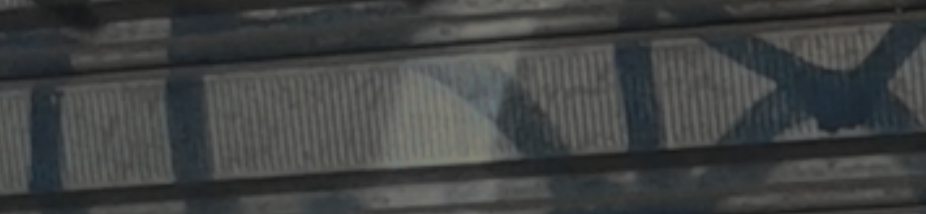

\section{GaUusP}

